) 
Cant Draks: 



\section{HEMIPTERA HETEROPTERA.}




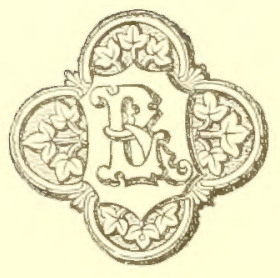




\section{HEMIPTERA HETEROPTERA}

OF THR

\section{BRITISH ISLANDS,}

A DESCRIPTIVE ACCOUNT OF THE FAMILIES, GENERA, AND SPECIES INDIGENOUS TO GREAT BRITAIN AND IRELAND, WITH NOTES AS TO LOCALITIES, HABITATS, ETC.

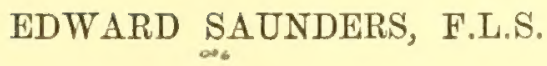

LONDON :

L. REEVE \& CO.,

Publishers to the Home, Colonial, and Indian Governments

6, Henrietta Street, Covent Garden.

1892. 


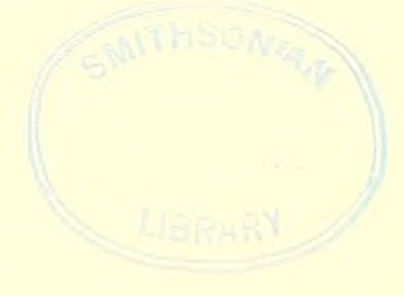




\section{PREFACE.}

The number of Entomologists who take an interest in the British Hemiptera has considerably increased of late years, although I fear it is an order which must still be looked upon as more or less "neglected." It is hard to see why this should be, as many of our species will compare favourably in beauty and delicacy with those of any other order. This delicacy of course makes their collection rather difficult, as they must not be handled, and their antennæ and legs are very liable to get broken; but a very little care will enable the collector to bring back his specimens uninjured, and when once he has got them home and set them, I feel sure he will be amply repaid for his trouble.

On the Continent of Europe a large amount of work has been done during the past ten years or so in this order, and the labours of Drs. Puton, Reuter, Horvath and others have cleared up a great deal of the confusion that used to exist in the European list. Dr. Reuter's magnificent work, "Hemiptera Gymnocerata Europæ," and Dr. Puton's "Synopsis des Hémiptères Hétéroptères de France" should be in the hands of all Hemipterists who can afford them. I have borrowed characters frequently from both of these, as well as from Dr. Horvath's numerous papers, Messrs. Douglas and Scott's standard work, "The British Hemiptera," and from the various works of Fieber, Stål, Thomson, Sahlberg, Lethierry, etc.

The object of the present volume is to give short descriptions of our genera and species, accompanied by synoptical 
tables, and as much information as can be gathered as to distribution and lncalities. I have avoided synonymy as much as possible, but have endeavoured always to rofer to Messrs. Donglas and Scott's "British Hemiptera" when the names I adopt differ from those employed by them; and where I use the expression "nec D. \& S." I mean that the species here described is not the species described under that name in their work. Many of these changes of nomenclature have been made by the authors of "The British Hemiptera" themselves in the pages of the Entomologist's Monthly Magazine. In collecting localities I have had much assistance from Major Blathwayt, Messrs. Billups, Blatch, E. A. Butler, G. H. Carpenter, Champion, Dale, Edwards, Dr. J. W. Ellis, Rev. Canon Fowler, Rev. W. F. Johnson, Rev. T. A. Marshall, Mr. A. Piffard, and Dr. F. Buchanan White, as well as from the following local lists: Hastings and St. Leonards and its vicinity; Lincolnshire, J. E. Mason; Norfolk, J. Edwards ; Devon, E. Parfitt; Reigate, J. Linnell. In nomenclature and arrangement I have followed Dr. Puton's "Catalogue des Hémiptères de la faune paléarctique," 3"me Edit. : Caen, 1886; but I have diverged from it in a few cases where $I$ have found it convenient to do so.

There are probably many new species yet to be added to our list, as some parts of the country have scarcely been worked at all. I have obtained very few Welsh localities, and the West of England and Scotland, as well as most of Ireland, have had very little attention from Hemipterists. It is hoped that the present volume will be useful to the few workers we have in this order, and may induce others to take it up as a study.

\section{Edward Saunders.}

St. Ann's, Woking,

November 9tb, 1892. 


\section{DESCRIPTION OF STRUC'TURAL PLATE.}

Fia. 1. Pronotum of Corixa distincta.

2. , , Falleni.

3. Face of Corixa semistriata, $\delta$.

4. " " limitata, o.

5. ", " Fabricii, ठ.

$6 . \quad$ " $"$ venusta, $\delta$.

7. ", , fossarum, 8 .

8. Elytron of Orthostira (Tingididx) (diagram). A. Sutural area; B. Discoidal ditto; C. Lateral ditto; D. Marginal ditto.

9. Elytron of one of the Capsidæ (diagram). A. Clavus; B. Corium; C. Cuneus; D. Membrane; E, E. Cells of membrave.

10. Elytron of one of the Cimicidx (diagram). A. Clarus; B. Corium; C. Embolium; D. Cuneus ; F. Membrane.

11. Wing of a Capsid, showing hamus of cell at $A$.

12. Upper side of one of the Pentatomide (diagram). A. Head; $A^{1}$. Central lobe of face; $A^{2}$. Antennæ; $A^{3}$. Eyes (compound); At. Ocelli. B. Pronotum; $\mathrm{B}^{1}$. Anterior angles; $\mathrm{B}^{2}$. Posterior ditto. C. Scutellum. $D^{1}$. Corium of Elytra; $D^{2}$. Clavus of ditto : $\mathrm{D}^{3}$. Membrane of ditto. E. Abdomen; $\mathbf{E}^{1}-\mathbf{E}^{5}$ Segments of Connexivum. $\mathrm{F}^{\mathrm{l}}, \mathrm{F}^{2}, \mathrm{~F}^{\mathrm{s}}$. Femora, libix, and Tarsi of legs.

13. Underside of one of the Pentatomidx (diagram). A. Head; $A^{1}$. Rostrum; $\mathbf{A}^{3}$. Antennæ; $A^{3}$. Eyes. B. Prosternum; $\mathbf{B}^{1}$. Acetabulum; $\mathrm{B}^{2}$. Coxæ; $\mathrm{B}^{3}$. Trochanter; $\mathrm{B}^{4}$. Femur; $\mathbf{B}^{5}$. Tibia; $\mathbf{B}^{6}$. Tarsi. C. Mesosternum, legs, \&c.s as prosternum. D. Metasternum, " Di. Orifice of odoriferous sac. E", E $\mathrm{E}^{2}$, \&c."Abdominal segments, the black dots being the stigmata. $\mathbf{E}^{2}$. Showing basal process, as in Piezodorus. $\mathrm{E}^{7}, \mathbf{E}^{8}$. First and second genital segments. 



\section{HEMIPTERA-HETEROPTERA.}

\section{TN'LRODUCTION.}

'The Heniptera, or bugs, may be known by their haustellate mouths, incomplete metamorphoses, and four wings. In the Heteroptera the anterior pair of wings, or elytra, are of a more or less coriaceous texture, except towards the apex, which is generally membranous, the posterior pair are membranous and folr up under the elytra; both elytra and posterior wings are often undeveloped. 'The pronotum in the Heteroptera is very large, and produced backwards as in the Coleoptera, as is also the scutellum, except in a few genera; the membranous apices of the elytra in the developed forms overlap, so that the suture is not straight as in the Coleoptera. Developed and undeveloped specimens of the same species often occur together, and in some the developed form is exceedingly scarce; in the undeveloped forms the elytra are generally shortened, and the membrane either curtailed or entirely absent, and the posterior wings abortive; there is also in some genera an intermediate or brachypterous condition, in which the posterior wings are shortened and the membrane comparatively slightly modified; in the brachypterous and apterous forms the pronotum is less developed posteriorly, and this modification has been the cause of the erection of many new species which are now correctly referred to their developed forms. In variability of shape tho 
ILemiptera probably hold their own against any other order, and as a rule the specific charucters can be derived from structure, and are well defincd; the gencric characters, on the other hand, are frequently obscure, which is especially the case in the large family Capsida, where the grouping of the species into genera is a labour of great difficulty. 'The larger or more comprehensive divisions again appear to be better defined.

The large majority of our species are vegetable feeders, existing on the juices of plants. but a ferv, as is well known, have a preference for animal nutriment; whilst some appear to relish either animal or vegetable juices. There are a few species in this country that appear to associate with ants, and more or less resemble them in appearance, especially when in motion; of such resemblances the most striking exarnple we have is that between the female of Systellonotus triguttatus and the worker of Lasius niger, amongst which both sexes of the bng may occasionally be found rumning. Dr. Reuter has found it actually in the nest of L. niger, and Mr. Donglas has found it in the nest of Formica fusca. 'I'he species of Pilophorus again frequently occur' in company with ants, which they certainly resemble in general appearance. 'The same may be said of the larva of Alydus calcaratus; Piezostethus formicetorum inhabits ants' nests, but does not resemble its lost. On the Continent there are many species very closely resembliug the Formicida, and Mr. Wroughton lately exhibited at the Entomological Society a most interesting specie's from India belonging to the Capsicle, which associates with Polyrhachis spiniger and bears spines on the pronotum, etc., corresponding almost exactly with those on the ant.

'The metamorphoses of this order of inscets being imperfect, the larval and nymph stites are active, and more or less resemble the imago, althurgh in many cases the resemblance is hard to trace; as, for instance, in the linvar of some of the Nabidx, that of C'ilocoris rescomaculatus, or 
Capsus Ianiarius; the ocelli, wings, and frequently the claws are not fully developed until the final state is reached; and in the Pentatomida the number of antennal joints is only four in the larval and five in the imaginal state; the insect is said to go through three changes of skin after it leaves the egg before it reaches the imago; after the first the larva increases in size and the rudiments of wings appear under the skin, according to Burmeister; after the second the wing pads, as Packard terms them, increase in size, and this stage is called the nymph or pupal state; after the third monlt the imago appears. Packard ("Guide Study Ins." (1883), p. 518) says:"The embryological development of such Hemiptera as have been observed corresponds very closely with that of certain Neuroptera," and he places them between the Coleoptera and Orthoptera-a position which they seem to occupy very naturally.

Fossil Hemiptera.-From Mr. Goss's papers on this subject, the Hemiptera seem to have appeared first at the close of the primary or palaozoic period; early in the Secondary or Mezozoic period they began to be abundant and widely distributed. The first known appearance of the Heteropterous Hemiptera is in the Lias; the species found there have been referred to the Genera Cimex and Belostoma; in the upper Oolite and also in the upper Eocene period they seem to have been abundant, as well as throughout the Miocene.

Internal ANATOMY.

The internal anatomy of the Hemiptera, though like that of the Coleoptera in many respects, differs in several essential particulars. 'The food passes from the groove in the rostrum directly into the oesophagus, there being no apparent pharynx, according to Burmeister, as in tho Coleoptera; the salivary ducts discharge into the ocsophacus close to its origin; the salivary vessels are usually four in P. 2 
number, but in Nepa as many as six; the ocsonhagris passes through the thorax as a straight tube, clistending at the base of the abdomen into a "broad, bladder-shaped, generally long and often imegularly folded stomach ;" this is not a sucking stomach, according to Burmeister, but is the first of several successire stomachs, and is, he says, without doubt, analogons to the crop of the Coleoptera and Orthopterw. The second stomach is "generally the narrowest and always the longest," and in function and structure seems to correspond to the proventriculus, although it has not the horny structures observable in the mandibulata; at its posterior end it is distended, in a bladder-like fashiou, beyond this again follows, in many of the genera, a third stomach, whose cavity in some genera is formed by four half-cylindrical tubes; in many, however, this third stomach is wanting, but in compensation the second stomach and other following intestines are longer; the duodenum and ilium are, nceording to Burmeister, practically wauting in the bugs, so that the stomach opens directly into the colon, which is terunuated by the apical opening of the abdomen; the nrinary vessels dischirge into the stomach near its posterior extremity.

The Nervous System, according to Packard, consists of the cephalic ganglia and two thoracic ganglia, of which the anterior is the smaller, which send off' two main trunts to the ablomen.

The Circulatory System, as in other insects, consists of a dorsal vessel or hent, from which the blood circulates through the blood vessels by the pumping action of the contractions and dilatations of that organ.

The Rexpiatory System is conducted through the agency of spiracles, which are orifices in the external surface of each segment, from which the tracher distribute the air through the system; these spiricles may be plainly seen when on the underside of the abdominal segments, and in most of the I'entatomidie they are blate. "In $N$ epu and 
Rianatra the body terminates in a long breathing tube, and the tracheary system in these two genera is very peculiar, being very largely developed; on the underside of the body there is a large air-bladder within the metathorax, leading from the spiracle, which evidently lightens the insect during its flight. In the abdomen the spiracles are only present on the third to the fifth rings; they are not, however, simple clefts in the wall of the body, but are closed by a sieve-like membrane, so that they perform the function of tracheal gills (Gerstaecker)." (Packard, "Guide Study Ent.," p. 537.)

The Reproductive System. -The male generative organs consist of the testes, the spermatic ducts, the seminal vessels, and ejaculatory duct terminating in the penis; the female organs being the ovaries, the oviduct and spermatheca and ejaculatory ducts terminating in the orifice of the vagina. The secondary sexual organs, or armature, will be considered under the head of external anatomy.

\section{External Anatomy.}

The Head.-This varies considerably in form, but not so much as in the Coleoptera; the face is horizontal or slightly declivous in most of our species, but in the waterbugs and a few others it is perpendicular, or even at an acute angle to the vertex, as in Corixa, etc.; in shape it is generally more or less triangular looked at from above, with the eyes contiguous to or near the anterior margin of the prothorax. Notable exceptions, however, frequeutly occur, such as may be found in the Coreidæ, in Limnobates, etc., in which the eyes are far remote from the pronotum, or where the triangular shape of the head is hardly maintained, as in some of the Pentatomidre and in the water-bugrs of the genus Corixi Notonecta, etc., where the triangular face points downwards. The compound eyes are lateral and vary much in size and in shape; as a rule they are round and only slightly 
promincnt, occasionally they are produced, or cven pericillate, as in Heuestaris; in the Corisida, etc, they are very large and triangular, and looked at from above occupy the whole of the sides of the heal ; the ocelli, when present, are two in number and often largo aud prominent; they are absent in many of the generu and very minute in others; in frout of the eyes, on the sides of the head, are the autenniferous tubercles from which the antenna spring ; these vary in size and are sometimes on the upperside and sometimes on the undersile of the head, e.g. they are hidden by the margin of the lead in the Pentatomidas in the Coreidre, Tingidido, Aradida, ctc, they are often prodaced laterally into a process or spine; the anteuma themselves are not very variable in form; they are generally four-jointed, but have five joints in the P'entatomida and the Nabida, six in the genus Velia, and as many as eight in tho genus Corauss; whereas the number is limited to three in some of the aquatic genera. In the eight joints of the antenua of the genus Coranus, one of the Reduviida, are reckoned certain very short supplementary joints which occur between the longer ones. As a rule they may be said to be filiform, but oceasionally the apical joint is enlarged and frequently, especially in the Capsidr, the second joint is more or less swollen, much so in Atractotomns, etc., and in ono genus, Heterotoma, it is much dilated and flattened; in the Reduvida the last two joints are grenerally thimuer than the preceding ones, and in the lingidide the third joint is abnormally long; in the Cryptocerata they are short and hidden under the hearl.

'I'he face is composed of three lobes, the central one of which is cousidered by most Entomologists to be analogous to tho clypeus of other orters. Messis. Douglas and Scoti, on the other hand, consider that the front of the crown, as developed in the Capsirla, is the clypens, and call the facial lobe mentioned above, the central lobe of the face; I have adopted their nomenclature as thero is no difliculty in 
appreciating which the central lobe is, and it seems to mo open to doubt as to which may be the true clypeus; the external lobes are the genæ or cheeks; from beneath the central lobe extends the labrum which is closely adpressed over the base of the rostrum; this latter organ springs from the underside of the head, which is excavated so as to receive its first joint in repose; when the rostrum is stretched out, the cavity will be seen to be covered by a sort of muscular membrane, and to the front of this membrane the rostrum is attached; it is usually three or four jointed, and is structurally a sheath open at the apex in which the four setre lie which are considered to represent the mandibles and maxillæ; the sides of the sheath fold over in front and almost or quite touch along a straight suture, so as completely to cover up the setx, which can be drawn out if necessary. The palpi of the other orders seem to be unrepresented here; in repose the rostrum generally lies adpressed to the sternum and sometimes even reaches beyond the centre of the abdomen, but in some genera it is short and bent at the base as in Salda, Reduvius, etc., so that it does not lie adpressed to the underside; it can be extended by means of the basal membrano-muscular hinge.

The Thorax.-This, as in other insects, is composed of three segments, the prothorax, mesothorax and metathorax, the upper surfaces of which are termed respectively the pronotum, mesonotum and metanotum, and the under, prosternum, mesosternum and metasternum ; the sides of the sternites are called the pleurr; the pronotum throughout the family is very largely developed and extends backwards to the base of the elytra and scutellum which it frequently more or less covers; it varies very greatly in form and is often constricted in front into a collar or a callose margin; the prosternum receives the anterior pair of legs, and the position of the acetabula or sockets into which the legs articulate is of considerable value in classification; the mesonotum 
only appears above in the scutellum, which is generally largely developed in this order and occasionally to the extent of covering the entire abdomen, as in the Scutellerina; frcm the sides of the mesothorax exteud the anterior wings, elytra, or hemelytra, as they are varionsly styled, and from the mesosterum the intermediate pair of legs; the metanotum, as in the Coleoptera, is completely covered by the elytra, from its sides extend the posterior wings, and from the metasternum the posterior pair of legs; on each side of the metasternum is placed the sac from which is emitted the odoriferous substance which gives such a peculiar smell to so many of the species of this order; the form of the orifice of this sac affords valuable distinctive characters for some of the genera; these orifices are situated near the posterior coxa. The thorax has consequently five pairs of appendages, the two pairs of wings and the three pairs of legs which must now be considered. The anterior wings or elytra are almost always coriaceous except at the apex which in developed specinens is membranous; in its most complex form it is composed of five divisions, corium, clavus embolium, cuneus, membrane; these are separated from each other by nerves and are senerally well defincd. In my description of the species 1 have thronghout considered the elytra as closed, so that the terms anterior, latcral, posterior, etc., refer to them in this position; under these circumstances the clavus is tho narrow strip of the elytra which lies at the side of the scutcllum, ite sides as í rule are nearly parallel; the corium is the whole of the part of the elytra lying ontside this, bounded at the apex by the membrane; in the Capside, Cimicidre, etc., the extermo-apical angle of the corium is scparated off and is called the cumeus, the latero-basal portion of the corium is also separated off in the Cimsicida and is termed the embolium. "The membrave is the apical portion of the elytra, it is present in nearly all developed specinens, its nerves valy very much in araugement; in the 
earlier genera they are numerous and generally longitudinal, sometimes springing from a transverse basal nerve, but in the Capsidre the neuration is very simple, consisting of a single well-defined nerve, which originates just beyond the inner angle of the cuneus, and encloses a cell ou the membrane, its other extremity being near the outer apical angle of the cuneus, a nerve from this divides the cell into two, in some cases this divisional nerve is absent; in the Cimicidre there is only a basal nerve which lies close to the apex of the corium; in the Tingidida the membrane is reticulated and almost like the rest of the elytra; in the Corixidie the membrane is almost nerveless.

The posterior wings are always membranous; the neuration varies considerably but it has not been used much for characteristic purposes; in the Capsida the presence or absence of the hook-like nerve which is emitted from the upper nerve of the wing cell is used for divisional purposes, but it is not constant, as in Asciodema some specimens have the nerve and some have not.

Of the legs the constituent parts of each are first the coxa ; this is moderately sized in most of the genera, but very largely developed in the Capsidw; second, the trochanter; a small joint between the coxa and the femur; third, the femur; those of the anterior and posterior legs are often more or less incrassated, and in the Lygæidæ the former are generally armed with a spine near the centre and often with several smaller spines near it; fourth, the tibia; these as a rule do not present any great variability of form, but the spines which they bear in some of the Capsidæ are useful in distinguishing genera apart; fifth, the tarsi ; these consist of one, two, or three joints, and afford valuable generic characters; in the Corixida the posterior tarsi are formed for swimming, being dilated, and somewhat oarshaped, fringed with long hairs; the anterior tarsi in the males of this family vary much in form and are uscful characters in distinguishing the species apart; the apical 
joint of the tarsi bears the clinw or claws and the pulvilli when present.

The Athdomen.-Lacaze-Duthics considers the abdomen of the Hemiptera to consist of eleven segments; the presence of some of these, howerer", is more or less theoretical, they being merely indicated by certain sclerites representing a portion only of the original segunent; looking at the abdomen from beneath, the basal segment is very short, and looks almost as if it were part of the thorax; then follow five well-defined segments, and beyond these five come what are termed the genital segments; these are usually two or three in number and are much modified for generative purposes; there is a complete ovipositor observable in the females of the Capside and some otber groups; and in the males, throughout the Heteroptera, what are termed the genital styles, which may be found lying one ou each side of the apical aperture, seem to afford grood specific characters, although they have not been ('m)loyed for such a purpose except where actually necessary. A curious organ occurs on the posterior margin of the upper side of the sixth abdomiual segment in the Corixida, and was first pointed out by Dr. Buchanan Whito (Eut. Mo. Mag. x. p. 60, etc.); this " consists of a chitinous plate attached to a short pedicle and provided with rows of closely set teeth;" the plate varies in shape and in the number of teeth in the lifferent species. Dr. White calls this organ the strigil and points ont that it has no doubt some connexion with the genital organs. In the males of Corixa the last four segments of the abdomen are asymmetrical; in most species the asymmetry is on the right sido and in a few it is on the left; "the strigil has a corresponding situation," but is not observable in all the species.

Collectiny, etc. - The insects of this order, especially those belonging to tho Capsidre, are in many cases so fragile that to lonch them with the finger's is to run a great risk of spoiling the specimens; the plan I have always anlopted for securing 
them is to use an ordinary Coleoptera bottle, with a glass tube through the cork, and to place the end of the tube directly over the creature; in an umbrella or net it is easy to secure any of the species, if they are running up the net or the sides of the umbrella, by just touching their hind legs with the under rim of the tube; they are almost sure to jump and fall backwards under such circumstances, right down the tube; of course the harder species of Pentatomida, Coreidx, etc, can be handled without fear of damage, but they often leave a very unpleasant smell on the fingers. For killing purposes I always use cyanide, which I put at the bottom of the bottle, covering it well over with a thick wad of blotting-paper, and over this a cone of white paper which should touch the sides of the bottle all round, so that no insects can crawl down between it and the glass; the great thing is to keep the specimens dry, as if they get the least wetted the membrane will curl up at the end; they should be set as soon as possible after capture. I believe the best way of mounting is to gum each specimen across a narrow strip of card and then pin through the card, by this means most of the underside can be seen, and if a slight sideways cant be given to the insect, both upper and under sides can be examined with ease; of course insects set like this do not look so picturesque as when mounted on card with all the legrs symmetrically stretched out, but as the raison d'étre of our science is to know the creatures under observation, every obstacle to thorough investigation ought to be removed, and a card under the, insect is a considerable obstacle, as all know who have to name neatly carded specimens of critical species; the very small species may be mounted on squares of card, but even then it is well to set them as much on their sides as possible. Each specinen should bear a locality ticket, with date of capture, etc., and a reference by a number or other sign to a register whero fullor particulars of locality, etc., cau be griven. 
There are few localities which may not be hopefully searched for Hemiptera, but the largest results may be obtained by sweeping and beating; certain species are to bo found only on their particular food plant, others seem to occur indifferently on plants of various natures; for sweeping purposes a strong brown hollaud bag-net on a landingnct riug, screwed into the end of a thick oak stick is about the most useful implement, and for beating, an umbrella covered with brown holland; marshy localities are good for Saldidre, etc., which run or jump on the mud, and Sphagnum in some districts produces good species; moss, rubbish, dead leaves and all such localities have their specialities and a few occur under bark; there are also many water species, and one genus, Aëpophilus, occurs on the sea shore below high-water mark, so that practically no locality should be passed over. Oaks, ashes, sallows, birches and firs are perbaps the most productive trees, although there are few that do not yield something to the collector; the most productive montlis are July, August and September, Jut many of the Hemiptera hybernate, so that they may be sought for all the year round with more or less success.

\section{'TABLE OF FARIILIES.}

(21) 1. Antenna free not hidden.

(21) 2. Abuomen not clothed heneath with a

GYMNOCERATA. silvery velvety pubescence-species not aquatic

(1) 3. Scutellum reaching at least to the base of the membrane. . .

(3) \&. Scutellum not reaching to the base of the membrane*

(18) 5. Mesopleure and metapleurie composed of one piece only, elytra without a cuneus

(1i) ti. 'Tarsi ¿-jointed

(1:) 7. Rostrum not bent at the base, "lying in repose against the under surface of the heat 
(11) 8. Antennw inserted above a line drawn from the centre of the eye to the apex of the face

(10) 9. Legs not very long and slender, femora not clavate at the apex . . . .

(9) 10. Legs very long and slender, femora clavate at the apex a drom

(8) 11. Antenne inserted below a line drawn from the centre of the eye to the apex of the face

(7) 12. Rostrum strut, bent at the base so that it does not lie against the under surface of head in repose

(14) 13. Rostrum long, ocelli placed between the eyes

(13) 14. Rostrum short, ocelli placed behind the eyes. . . . .

(6) 15. Tarsi 2-jointed . . . . .

(17) 16. Anterior legs inserted on the posterior margin of the prosternum

(16) 17. Anterior legs inserted in the disc of the prosternum a met a

(5) 18. Mesopleure and metapleura composed of several pieces, elstra with a cuneus.

(20) 19. Elytra with an embolium . - .

(19) 20. Elytra withmut an embolium

(2) 21. Ahdomen clothed beneath with a silvery
velvety pubescence; species aquatic or sub-acuatic

(2:3) 22. Antenna 5-jointerl . . . . . HeBRrde.

(22) 23. Antennæ 4-jointed : : Hydrometrid.

(1) 24. Antenna hidden in forex under the head . CRYPTOCE-

$$
\text { RA'T'A. }
$$

(28) 25. Anterior less inserted on the disk or an. teriur margin of the prosternum

(27) 26. Antennx with 4 simple joints, no anal

(26) 27. Antendix with 3 joints, abdomen with a long anal tubular appendix

(25) 28. Anterior legs inserted on the posterior
margin of the prosternum.

(30) 29. Rostrum free, 3-to 4 jointed. : : Notonectin.

(29) 30. Rostrum hidden, apparently unjointed . Corixids.

\section{G Y M N OCER ATA. PENTATOMIDF.}

Species short and wide, often subtriangular in form, head with its margios more or less foliaceons or acute, antenne 5-jointed, pronotum in some produced at its 
posterior or lateral angles into spines or lobate processes; scutellum very large, reaching to the base of tho membraue, or in tho Scutellerina almost or completely covering it. Flytrin composed of clavus, corium, and membrane. Connexivum usually more or less reflexed. Legs simple iu most of the genera, but spinose in the Cyduina. 'Tarsi 2 to 3 -jointed.

Of this showy family we have only a few genera in Great Britain, they all occur on various trees and plants, and most of the species may be saicl to be more or less rare, only a few really occurring in abundance.

\section{TABLF OF SUB-FANIIJES,}

(2) 1. Scuteilum very nearly or quite covering the

(1) 2. Seutellum nut nearly covering the menbrane

(4) 3. Tilias spiny

ŚCUTEILEINA.

(3) to Tibia not spiny

(8) 5. Tharsi s-jointell

(7) 6. Rostrum long and sleuder : . Pentatonina.

(b) 7. Rostrum stout . . . Asuriva.

(5) 8. Tarsi "2-jointed, alrdomen beneath with a central carina. . . . Achantitosomina.

\section{SCUTELLERINA.}

(2) 1. Fintire insect hairy . . . . Opontoscelis.

(1) 2. Insect not liairy

(4) 3. Leers with distinct strong spines. . Cormalema.

(3) 4. Less withont spines or with very short ones

(i) 5. Anterior :uncles of pronotum produced into a blunt touth-like process . . . Ponops.

(ii) 6. Anterior angles of pronotum simple : Eurygaster.

\section{ODONTOSCELIS, Lap.}

Of this well marked genus there are only three European species, of which we bave only owe in this comntry; they all occur in sandy localities, fuligimsus being found on on coasts under Erolinu, cte. 1). Aorsalis ocen's in France on the sandhills of the north coist, aud my yet be adhed to our list; it may be known from futiginosus by the silvery pubesence of its under side. 
0. fuliginosa, Limn.-Short, oval, widely rounded anteriorly and posteriorly, very convex, clothed with short hairs; brown or black, mottled and spotted with darker and lighter markings, very variable in colour, but almost always with a pale dorsal stripe extending from the front margin of the pronotum to the apex of the scutellum, head rounded in frout, pronotum transverse, its sides rounded, just above the posterior angle with a narrow deep emargination, scutellum entirely covering the membrane, slightly narrower than the base of the pronotum; connexivum just visible beyond the margins of the scutellum.

L. $6-9 \mathrm{~mm}$.

Sandy places, sandhills Deal, not rare. Sandhills Burnham, Norfolk, Curtis; Sandown, Chumpion; near Fakenbam, Di. Schrinshire, fide U. W. Dule.

One well marked variety of this species is quite black with the dorsal line of the pronotum and two parallel lines on the scutellum, one on each side of the dorsal line, which is often abbreviated, pale whitish.

\section{CORIMELENA, White.}

A small semi-globular, glabrous, bronzy genus of which only two European species are known. Our British one has, so far as I know, only been recorded as occurring in moss and dead leaves and by casual sweeping, but Dr. Puton, in his "Synopsis des Hémiptères Hétéroptères de France," says it occurs by sweeping in meadows, especially on Ranunculaceous plants.

C. scarabæoides, Linn.-Small, nearly round, dark bronzy coloured, shining, glabrous, strongly punctured; antennæe piceous; scutellum not quite covering the corium and membrane; legs black, tibir spinose, tarsi piceous.

L. $3-4 \mathrm{~mm}$.

Reigate Hill in moss, Deal, Woking, Purley Downs under fallen leaves, Gloucester, Micklcham, Sandhills near Burnham ; Headley Lane, Reigate, Margate, Cardiff, Billups; 
Shalfori, Surrey, Butler; Exeter, Prerfitt; Norfolk, Edwarlo'; Chatham, Darenth, Caterham, Chrmpion; Folkestone, Carshalton, Rye; St. Osytb, Croydon, Bunmemouth, Blateh; Lulworth, J. C. Dile.

\section{EURYGASTER, L(}

A genus of rather large flat species, of a dull brown on testaceous colour, sometimes variegated with darker brown, or purple brown markings; scutellum extending quite to the apex of the abdomen or beyond it. Our two British species are easily distinguished.

(2) 1. Sides of the prothorax straight, scutellum not keeled longitulinally . . Mr. . . .

(1) 2. Sides of the prothorax curved, scutellum keeled longitudinally . . . . . NIGRA.

E. maura, Limn.-Brown or ochreous more or less mottled with darker or purple brown, decply punctured with black punctures. Head with the central lobe not enclosed by the cheeks, antennow black at tho apex; prothorax with its sides straight or slightly sinuate, posterior angles somewhat prodnced; scntellum without a raised lieel but with a smooth central line at the base, and a raised smooth tubercle on each side, about midway between it and the external margin; connexivum produced, spotted with black, its margin rounded, under surface and legs ochreous punctured with black.

L. $8-10 \mathrm{~mm}$.

By sweeping, Folkestone, IVoking; Headley Lane, Deal, Carditf, Billups; Dallingtou Forest, Sussex, Ewhurst, Surrey, Butler; Reigate, Linnell; Chatham, Champion; Glanvilles Wootton, Portaud, Lands Eud, Whittlesea Mere, J. C. Dale.

E. nigra, $I^{\prime} u b$ - l'ale ochreous, deeply punctured, in somo virieties more or less mottled with darker colour, and in some Coutinental varicties nearly hlack. Head with 
the central lobe enclosed by the cheeks, antemna with the apical joint black; pronotum with its sides rounded, the posterior angles not prouinent; scutellum narrower in proportion than in maura, distinctly keeled down the middle for more than half its entire length, base without lateral tubercles; connexirum narrow, unspotted.

L. $12 \mathrm{~mm}$.

Rare, sandhills, Deal ; Margate, Billups.

\section{PODOPS, Lap.}

A genus recognizable at once by the curious appendages to the anterior angles of the pronotum. There are several very closely allied species found in Europe of which we have only one in this country.

P. inuncta, Fab.-Dark brownish ochreous, deeply impressed with black punctures. Head black, central lobe ochreous, narrow, not enclosed by the cheeks, between the antenne and the eye on each side a distinct somewhat triangular tubercle; pronotum with the anterior angles produced into somewhat dentiform appendages, dilated at the apex and especially produced on the anterior side; scutellum slightly constricted before the middle, with three pale basal tubercles; connexirum narrow; legs with the femora banded beneath with two black bands.

L. $5 \frac{1}{2}-6 \mathrm{~mm}$.

Not uncommon by sweeping, Woking, Choblam, Reigate, Deal, Worthing, Herne Bay; Devonshire rare, P'cufitt; Norfolk rare, Ellwards; Folkestone, Rye; Sandown, Chumpion; Weymouth and Weston-super-Mare, Blutch; Glanvilles Wootton, Portland, Dule; Hastings, Pegrwell Bay, Butler; Orpiugton Kont, Headley Lane, Oxshott, Billups.

\section{CYDNINA.}

Anterior margin of the lread entire, margins of head and pronotum with long hitirs. Geotonus. 
Anterior margin of the head more or less emarginate, margins of head and pronotum withont hairs. Eyes riewed from the front nearly semicircular, exserted from the head for abont balf their width viewed from the front transverse, exserted for nearly three-quarters of their width

SEIrItes.

Grathocontus.

GEOTOMUS, Muls. and hey.

$\Lambda$ small genus containing a few very closely allied species; of these we have only one in Britain, which may be easily known by the long hairs of the pronotum and hoad from those of any of the other British genera of this fomily.

G. punctulatus, Costa ; (Ethruslievis, D. and S.).-Oral, shining, pitchy black, inclining in inmature examples to piceous, or even testaceous brown; antemura and legs piceous. Head semicircular, the cyes hardly exserted beyoud the lateral mirgins, margins with loug hairs, pronotum with the auterior margin strongly concave, the sides regularly rounded, the base nearly straight, surface impunctate in front, punctured posteriorly; scntellum deeply and closely punctured; elytra sparscly so, membrane whitish; legs with the tibiro closely and strongly spinose.

L. $3 \frac{1}{2}-4$ mm.

White Sand Bay, near Land's End, Coruwall, under stones, Erodium, etc.; two specimeus under stones, Cuwbridgre, S. Wales, Billup.

\section{SEHIRUS, LiH. S.}

A genus of blue or black species often with white markings, they occur generally by streeping or in sandpits. The glabrous margins of the head and pronotum distin. guish it from cieotomes, and the form of the eyes from its nearest ally, viz. Guthocmus.

6) 1. More or less spotter or marked with white

(3) "2. Siltes of pronotum and corium only nargined with white 
(2) 3. Corium more or less spotted with white

(5) 4. Hack, corium with only a small central spot: BIGUTIATUS.

(4) 5. Blue black, corium with a large basal and

smaller apical spot . . . . Bicolor.

(1) 6. Entirely black . . . . . MoRro.

S. bicolor, Linn.-Blue black, slining, gìabrous. Head with its anterior margin slightly emarginate, the margins raised and reflexed, antenna long, black; pronotum deeply punctured, with two irregnlar smooth elevations before the middle, sides slightly rounded, each with a narrow white spot extending from the front angle to just beyond the middle; scutellum and elytra deeply punctured, the corium of the latter with its basal two-fifths white, the white colour emarginate in the centre of its claval margin, the apex of the corium also is white, membrano whitish; connexivum beneath spotted with white, and the apical segment in the of margined with the same colour; legs blue black, bases of the tibio externally white.

L. 6-7 $\mathrm{mm}$.

By sweeping, Chobham; Weybridge, Headley Lane, Lee, Dulwich, Cardiff, Billups; by sweeping nettles, etc, Wymondsley, Herts; in ivy, Shalford and Gomshall ; under Artemisia St. Albans, Butler; Norfolk, common, Edwards ; Devon not common, Parfitt; Reigate, Limnell; Croydon, Leamington, Blutch; Darenth, Champion; Parley Heath, Dale; Oxford.

S. dubius, Scop.-Purplish-blue, glabrous, shining, deeply punctured sides subparallel, margins narrowly white. Head punctured, its margins strongly reflexed; antennæ blue black, pronotum with its anterior margin deeply concave, its sides much rounded, and narrowly yellowish white, its base nearly straight, disc with a deep transverse impression, in front of which is a smooth elevation; scutellum punctured; corium punctured, with its lateral margins narrowly yellowish white, its apex sinuate just at the scutellar angle, membrane whitish; connexivum spotted with white; underside and legs blue black.

$$
\text { (1) }
$$


L. $6-7 \mathrm{~mm}$.

Isle of Wight, Brewer; Horsley Surrey, Billups; Cater ham and Sandown, Champion; Weymouth, Blutch; Chesil Beach, C. W. Dale; Hodd Hill, J. C. Dale.

S. biguttatus, Lim.-Black, shorter and more irregularly oval than the preceding, deeply punctured, margins of pronotum ard elytra and a discal spot on each of the latter white. Head rugosely punctured, its margins slightly reflexed, antenux with the apical joint considerably longer than the preceding; thorax very largely punctured with a deep transverse central impression, sides slightly rounded, margined with white; scutellum punctured, more or less wrinkled; elytra punctured, more closely towards the lateral margins, sides rounded, narrowly white, disc of the corium with a small round white spot; membrane black; connexivum margived with white; beneath, and legs black.

L. $5-6 \mathrm{~mm}$.

Guestling near Hastings, in sandpits, etc.; in moss under or near Calluna, Hurst Green, Battle, Guestling, Butler; Deal, and Loughton Essex, Billups; Dunsford, Stoke, Devon, under dead leaves and Pelticho cunina in February and March, Larfitt; Reigate, Limell; Sheppy, Darenth, Chatham, Chumpion; Pitlochry, Normun; Loch Ranuoch, Murshall; Parley Heath, J. C. Dale; Lyuton, C.TV. Dale.

S. morio, Lim.-Black, regularly oval, punctured, basal joints of the antenna pale. Head rngosely punctured, its margins very slightly reflexed, basal two joints of the antenno and the extreme base of the third pale; pronotum closely and deeply punctured, with the sides and base slightly rounded, dise with a smooth elevation in frout of the middle; scutellum and elytra closely and deeply punctured, entirely black, posterior marnin of the corium, straight; membrane whitish; bencath and legs black, tho latter very strongly spinose.

L. 7-9 $\mathrm{mm}$.

Reigatr, Higham Leut, Cardiff, Billups; Stoke IVood 
near Exeter, under Peltidea, Purfitt; Mickleham, Champion; Lulworth, Bournemouth, Dale.

\section{GNATHOCONUS, Fieb.}

This little genus is closely allied to Sehirus but the transverse eyes will easily distinguish it. Its species are also rather more convex, and the central lobe of the face is not enclosed by the cheeks.

(2) 1. Head with the central lobe shorter than the cheeks, apical joint of the antennx longer than the fourth . . . albomarginatus.

(1) 2. Head with the central lobe reaching the front margin, fourth and fifth joints of antennæ subequal . . . . PICIPES.

G. albomarginatus, $F a b$.-Short oval, black, punctured, sides of the eytra narrowly whitish. Head rugosely punctured, central lobe shorter than the cheeks and so forming a notch in the front margin, antenna with the first and second joints pale, apical joint distinctly longer than the fourth; pronotum convex, strongly and deeply punctured, sides rounded, base nearly straight; scutellum punctured, and somewhat wrinkled, corium punctured, lateral margins slightly rounded, narrowly whitish, apical margin straight, membrane whitish; legs spinose.

L. 3-4 mm.

Woking, Wandsworth, Reigate, Bromley; at roots Hastings, Bexhill, on sandy bank Shalford, Butler; by shaking moss, Reigate and Headley Lane, Billups; Exmouth, Haldon, Sidmouth, Parfitt; Norfolk not common, Edwards; Croydon, T'onbridge, Isle of Wight, Blatch; Darenth, Ashstead, Sandown, Champion.

G. picipes, Fall.-Very like the preceding but with the central lobe of the face extending in front as far as the cheeks, the apical joint of the antennw shorter, being only subequal in length to the penultimate, and the pale margin 
of the elytra cxtending only for about two-thirds of their entire length from the base.

L. 3-4 mm.

Chobham, Bromley; Mablethorpe, Lineolnshire, 'T'. I'. Itollustun; sindluills Yarmouth, scarce, Norwich, Lidwerds; Sandown, Champion.

\section{PENTATOMINA.}

(i) 1. Sictes of the thomx foliaceons . . Scioconis.

(1) 2. Sides of the thorix not foliaceous . .

(ii) 3. Head pointed in front, and from a sideways view much arched downwarts

(5) 4. Head clongate, much attonuated in front. . ELIs.

(4) 5ead short, subtriangular . . . . Neutriglossa.

(3) 6. Head mearly horizontal, rounded or sultruncate in front . . . .

(10) 7. Second ablominal segment beneath with it tubercle or process directed interiorly

(9) 8. Process elongate, reaching to the intermediate coxw, pronotum with the sides simple. . . . . Prezodores.

(8) 9. Second abdominal segment with only a slight tubercle in front, sides of the pronotum produced near the posterior angles. Troriconis.

(7) 10. Second abdominal regment simple

(1)) 11. Head concave, its margins mised . S Strachia.

(11) 12. Head not concave, its margius not raised .

(1 ii) 13. Species nut very short and robust and small; orifice of the odoriferous sac prolonged exteriorly into a transverse gruove .

(15) 1t. Heal somervat pointedly rounded in front, central lobe of the face enclosed by the cheels. l'enibat's.

(1.) 15. Heal sulutruncate, or bIuntly rouuded in front, central lobe free. . . . . Pestutos.

(13) 10. Species very short and robust, small, urifice of the ouloriferous sac short, not 1rolungecl into a groove . . . . Ersarcolis.

\section{SCIOCORIS, Full.}

This geuns is one of the most puazling of the European 
genera in regard to the discrimination of its species. They aro all closely allied and of a very sinilar facies, by which they may be at once known from those of any other genus. They are of a sandy brown colour, generally punctured with black punctures, depressed in form with the margins of the head and pronotum very thin and foliaceons; the eyes small and black, more or less prominent; the connexivum dilated and flat. We have only one species in Britain.

S. cursitans, Fab.-Pale ochreous, punctured and more or less mottled with black. Head about as long as wide, somewhat pointedly rounded in front, antenne slightly darker, eyes exserted for a little more than two-thirds their diameter; pronotum transverse, deeply sinuate in front, the base of the sinuation straight, sides slightly rounded, base slightly produced, straight across the base of the scutellum, disc closely punctured; scutellum punctured; clytra with the corium at its apical angle reaching to about the length of the scutellum, membrane not reaching to the apex of the abdomen; connexivum with transverse dark bands; abdomen benenth with a spot on the sixth segment and a line along the sides near the centreblack; legs oclreous.

L. $4: \frac{1}{2}-6 \mathrm{~mm}$.

In sandy places; sandhills, Deal, Sandrich.

FLIA, Fat.

The elongate head and pointed nose of the species of this genus are so characteristic that they distinguish them at once from those of other genera. We have only one species in this country, which is curiously distinguished from all the other European species by having two small black spots on the intermediate and posterior femora beneath, whereas the others have never more than one; this may seem a trivial character, but it is very constant.

E. acuminata, Lim.-Shining, ochreous, longitudinally striped with pale and darker strijes, somewhat elongate, 
head and thomax forming a triangle of which the base of the thurax forms the base, the elytra forming a reverse longer triangle, with the same hase. Head punetured, longer than wide, pointed in front, with a dark central stripe, its centro pale; pronotum punctured, sirles straight, base slightly produced, nearly straight across the scutellum; dise with a broad dark longitudinal band, its centre narrowly frale, sides witl a narrower dalk band just within the lateral margins; scutellum punctured, with a pale centrul line, shaded with is darker colour on ench side; corium pale, without markings, punctured; membrane hyaline; abdomen above black with yellow markings, beneath pale; stigmata black; lexrs pale, second and third pairs of femora bearing two black spots beneath.

L. 8-9 mm.

Reigate, Worthing, Woking, Shiere; Darenth Wood, Deal, Combridge S. Wales, billups; N. Yarmouth, Curtis; Hastiugs, Saudown, Mickleham, Weyloridge, Direnth, Brandon, Champion; Hythe, Blatch; Lulworth, Dale; 'Teignmouth, Blumer.

\section{NEOTTIGLOSSA, Cuit.}

Elioides, $D_{0}, h_{i}$,

A small genns somewhat allied to Eilie althongh 5 ery tifferent in the shape of the head; it may, howover, be distinguished, in common with that gemus, from the others of the P'entatouna in having the head bent downwards in front. In this gemus again we have only one species.

N. inflexa, Wolfi-Small, shining, ochreous, punctured with black, sides of the elytra subparallel, antenva with the fourth and fifth joints black, abdomen beneath brouzy. Hcad darker than the pronotum, deeply punctured, snt)triangular, deflected in front, checks enclosing the central lobe; pronotum punctured, the sides nearly straight, 
anterior angles laterally acute, posterior angles slightly prominent, base sinuate, dise with a pale dorsal line; scutellum and elytra punctured, the former with a dorsal line, and a basal callosity on each side, pale; abdomen beneath bronzy, punctured with black; legs reddish ochreous, spotted with black at the apex of the femora.

L. $4-4 \frac{1}{2} \mathrm{~mm}$.

By sweeping, Bromley, Woking; Weybridge, Virginia Water, Darenth Wood, Headley Lane, Deal, Billups; Battle and Dallington Forest, Butler; Howe Grove, Norfolk, Edwards; Bewdley Forest, 'Tonbridge, Bournemouth, Blatch; New Forest, Chompion; White Sand Bay, near Plymouth, J.J. Walker; Folkestone, Rye; Glauvilles Wootton, Portland, Dale.

\section{EYSARCORIS, Hech.}

A genus of short, wide, convex species, of a dull bronzy ochreous colour, of which we have two in Great Britain, they occur by sweeping and are both rare, especially it!l lls.

(2) 1. Scutellum with a large bronzy basal spot without pale callosities . . . . MELANocePUALUS.

(1) 2. Scutellum without a basal spot but with two lateral white callosities at the base. ExEUS.

E. melanocephalus, Fab.-Greenish ochreous, strongly punctured with bronzy punctures. Head purplish bronzy, very closely punctured, central lobe as long as the cheeks, antennæ with the fourth and fifth joints black, pale only at the extreme base; pronotum slightly sinuate in front, anterior angles produced into a very small lateral point; sides mearly straight, posterior angles rounded, base produced, nearly straight across the scutellum, disc raised posteriorly, deeply punctured, near the front margin are two purplish spots; scutellum punctured, with a large bronzy purple basal spot; elytra punctured, membrano 
slightly tinged with brown; bencath bronzy, sides of the abdomen beneath, and comexivum above spotted with yellowish; legs testaceous, femora spotted with black.

L. 5-6 imm.

New Forest, T. B. Wells, Darenth Wood; Weybridge, Tillups ; Hawkhurst, Butler ; Esher, Chatham, Champion; 'Tonbridge, Whittlesea, Jiluth; Folkestone, Rye.

E. æneus, Scop,-Greeuish ochreous, strongly punctured, posterior angles of prouotum produced. Head bronzy, elongate, central lobe not so hug as the checks, antenuw with the fourth and fifth joints black, extreme hase of the fourth pale; jronotum with the anterior margin sinuate, its angles slightly produced laterally, sides siunate, posterior angles moduced and pointed, oxtending considorably beyond the base of the elytra; base produced, its central portion straight; disc strongly punctured, raised posteriorly, near the front margin are two indefinite bronzy patches; scutellum punctured, at each side of the base a prominent smooth pale callosity; elytra punctured, membrane dusky; abdonen with the comexivum pale, spotted with black; beneath bronzy in the centre, the sides pale, stigmata black; legrs pule, tho femora sprinkled with small black spots.

L. $4 \frac{1}{2}-5 \mathrm{~mm}$.

Rare, New Forest; Faversham, J. J. Waller.

\section{PERIBALUS, Muls. and $l$.}

$\Delta$ genus of only a few species, five only being recorded from Lurope. It is closely allieul to Pentatoma, but the structure of the head will distinguish it from that genus. We have only one species, whose right to a place in our list depends upon a very few specimeis tatien years agro. I have one specimen from the late Mr. Croteh's collection carded, with "Weston S. Mare" written on the back of the card, and one without locality frow the late Mrr. Inurding's collec- 
tion. Messrs. Donglas and Scott quote Croteh's specinen and another without locality. 'Ihe Rev. T. A. Marshall records it from Cumberland.

P. vernalis, Hulfi-Dull, ochreous brown, densely punctured with black, antenno orange yellow, a band across the middle of the fourth joint, and the fifth, except at its base, black. Head flat, rather pointedly rounded in front, central lobe not nearly reaching the front margin; pronotum sinuate in front, its lateral margins sinuate, narrowly white, the posterior angles much produced and rounded, base nearly straight; scutellum and elytra punctured, wembraue slightly smoliy, abdomen above black, connexivum with whitish spots, beneatl palo greenish yellow; legs pale ochreons.

L. $10-11 \mathrm{~mm}$.

Very rare, Weston-super-Mare; Borrowdale Cumberland, Marshall.

PENTATOMA, Oliv.

I have given under this head what the Continental authorities refer to three different generi ; the character's are not very striking, and we have so few species in this country that I thought it was hardly desirable to wake a genus tor nearly every species. Our British species may be thus distinguished:-

(4) 1. Connexivum spotted with blask (subg. Carpocoris).

(ii) 2. Posterior angles of the pronotum produced into sharp points. . . ruscispina,

(2) 3. Posterior angles of pronotum simple . . BACCARUM.

(1) 4. Connexivum unspotted.

(ii) 5. Lateral margins of the provotum raised (subg. l'entatoma) . . . J of

(6) 6. Literal nargins of pronotum not rised (subg. Palumena) JUNIPEIIN d.

\section{(Subgends CARPOCORIS.)}

P. fuscispina, Boh. (baccomm, ES. Synopsis).-Dull, yollowish ochreous, more or less tiuged will red, augles of 
pronotum prominent, black, anteune black. Head elongate, its sides more or less dark, its apex suffused with red; pronotum with its front margin deeply coneave, sides sinuate, strongly reflexed to the posterior angles which are raised and produced into two sharp) angular processes, mar"gins red, amgles black, dise closely and rugosely punctured; scutellum and elytra punctured; connexivum with darker trmsverse bands, legs with the tibio and tarsi red.

I. $14 \mathrm{~mm}$.

I only know of a few British specimens, all taken in Devoushire, one by the late $J$. A. Brewer, two recorded by Parfit, one from 'I'eignmouth, Cupt. Blumer, and two from Bickley Woods, Bignell.

P. baccarum, Lima.; (verbasci, De Geer).-Brownish ochreous, hairy, with more or less of a purplish tint, antenna and comnexivum bander with black, scutellum white at the apex. Head closely and deeply punctured with black, cheeks longer than the central lobe; antenna with the basal joint pale, the rest black, pale at their bases; pronotum with the sides rised, nearly straight in front and rounded at the posterior angles which are not produced, disc punctured, with crect scattered hairs; scutellum punctured, hairy, its aper narrowly white; elytra punctured, membrane smoky brown; conuexivum with large black spots; beneath pale ochreous, with rows of black punctures; legs ochreons, hairy, tarsi darker.

L. $13 \mathrm{~mm}$.

Hastings, Ewhurst, Butler; Reigate, Oxshott, Chobham, Billups; Devon, Perfitt; Norfolk, Edwards; Glanvilles Wootton, Laud's End, Dale; Scilly Isles, Mason; Knowle, Bowdley, St. Osyth, Barmouth, Blatch; Howth and Dingle Ircland, Carpenter.

\section{(SuBgexus PENTA'TOMA.)}

P. juniperina, Lim.-Convex, bright olivo green, inargins of pronotum and of the base of the clytra and the 
connexirum pale. Head punctured, antenux darker towards the apex; pronotum very closely punctured, its lateral margins narrowly raised and ochreous, slightly rounded, posterior angles simple; scutellum and elytra closely punctured, the former slightly wrinkled transversely and with the aper pale, the latter with the lateral margins at the base narrowly rufescent; connexivum pale, beneath and legs concolorous with the upper surface.

L. 12-13 $\mathrm{mm}$.

On Junipers, Sanderstead, Caterham and Mickleham, rare.

\section{(Sobaenus PALOMENA.)}

P. prasina, Limn.; (dissimilis, Fab.; viridissinu, ES. Syn. nec Poda).-Rather a flat species, bright green, punctured, lateral margins of pronotum, connexivum, and underside reddish, legs green. Head punctured, antennæ reddish, apical joint black, excent at its base; pronotum with its lateral margins narrowly red, nearly straight, the posterior angles somewhat raised and produced, rounded, dise strongly punctured, with two little long trausver'se fovex behind the front margin; scutellum and elytra punctured, the apex of the former pale, and the base of the lateral margins of the latter reddish; membrane dark brown ; connexivum black, with paler transverse lines; benerth reddish, legs pale green, sometines tinged with red.

L. 13-14 $\mathrm{mm}$.

Not rare; "common everywhere on raspluerries," Devon, Parfitt; Headley Lane, Orpington, Cardiff, Billups; Bideford; Guestling, Battle, Hollington, Butler; Rodhill, Linnell; Glanvilles Wootton, Land's End, Dalo; St. Osyth, Ilfracombe, Barmouth, Blutch; Chatham, Champion.

\section{STRACHIA, Iluhn.}

Specios glabrous, shining and brightly coloured, scarlet, 
green or blue, more or less variegated with other colours; distinguished from the other genera of the Puntatomiua by having the orifice of the odoriferous sac indistinctly indicated and im-marginate, and the margins of the head rellexed. The species are in many cases very closely allied and the markings are often very variable, but we have ouly two liritish species which are easily distinguished from each other; they occur by sweeping and are both uncommon.

(2) 1. Bright rel with blinck-blue markings . . . FESTIVA.

(1) ¿. Green with ochreous or rekldish markings . . OLERAcha.

S. festiva, Limn; (ormata, D. and S.).-Shining red, with large black spots, membrane, antemma and legs black. Ilead black, deeply punctured, contral lobe depressed, margins raised, red; pronotum red, with the anterior and lateral margins narrowly reflexed and with a raised transverse line just before the middle, disc largely and remotely punctured, with two black spots in front and four behind; scutelium punctured, red, with a large basal spot and two small latemal apical spots bluc-black; elytra punctured, red, with a lirge spot entirely covering the clavus, and extending in two lobes across tho inner part of the corium and a small round apical spot, blue black; membrane black; connexivum red, abdomen above mostly red; beneath with the centre and a row of large spots down each side black, legs black.

I. $6-7 \mathrm{~mm}$.

Rinre; Alton on a gooseberry bush, Dallington Forest, Battle on Umbellifers, Iintler; Hastings, Deal, Cardiff, Billups.: 'Toubridge, Blutch; Stockbury, Kent, Champrion; Norwich.

S. oleracea, Limn.--Shiuing, lorouzy or olive green, with yellow or red markings, antenne black, posterior and intermediate tibic handed with yellow. Head bronzy green, its maruins whitish; pronotum bronzy or bluish-green, remotely puncturut, anterion and lateral margins reflexed and pale, dise with a broal pale doral stripe 
widened at the base, across the centre there is a deep transverse impression; scutellum punctured, blne green, with the apex and generally a lateral stripe yellow; elytra punctured, blue green, with the lateral margins and a transverse spot near the apex yellow; connexivum spotted with yellow, abdomen beneath blue green, legs with the intermediate and posterior tibice with a broad pale band in the centre, anterior tibia with a pale spot bencath.

L. $6-7 \mathrm{~mm}$.

Rare, Deal, Chobham; Exeter, Purfitt; Kynauce Cove, Bristol, Dale; Kings Stanton, Gloster, Bluteh; Isle of Wight, Lewis; Cambridge, Bond.

\section{PIEZODORUS, Ficb.}

Only one ont of the tro Palrarctic specieso ccur's in this country, it may be generically known at once by the long process on the second abdominal segment; this is carried forward between the posterior and intermediate coxa, tepminating in a blunt point just in front of the latter.

P. lituratus, Fab.; (quipnteipennis, D. and S.)-Large, punctured, dull olive green, often with the pronotum posteriorly and the elytra reddish, or purple, legs pale, antenna red. Head closely punctured, central lobe reaching the front margiu, antenne red, apical joint rather darker; pronotum punctured, lateral margins very narrowly reflexed and pale, posterior angles slightly projecting beyond the base of the elytra, disc raised between the posterior angles, in front of the middle with two narrow, transverse, pale impressions; scuteilum and elytra punctured, membrane sublyyaline, abdomen above black, connexivum pale, beneath green, stigmata black, legs slightly tinged with red.

L. 10-1:3 mm.

Common and generally distributed, occurs ospecially on broom and furze, in the autuun. 


\section{TROPICORIS, Hahn.}

Another genus of which we Lave only one representutive. It may be known from all the other genera of the Pentutomina by the long narrow rostrum, and slightly tuberculated second abdominal segment, whose base is not produced into a long process as in P'iezodorus, but bears in its centre a slight tubercle pointiug forwards; the largely produced lateral angles of the thorax are also characteristic of the genus; in this respect it resembles Podisus, but the narrow rostrum will at once distinguish it therefrom.

T. rufipes, Limn.-Reddish bronzy-brown, posterior angles of the pronotum produced into somewhat rounded processes, with the actual angles acute. Head rather elongate, deeply punctured, central lobe reaching to the apex; antenne red, fourth joint, towards the apex, and fifth dusky; pronotum with the anterior angles acutely produced, the lateral margins red, rugose, sinuate in front, raised aud rounded near the posterior angles, which are really situated almost midway between the apical and basal margins of the pronotum, the angle itself acute, base much produced, straight across the base of the scutellum; dise very strongly punctured with black; scutellum punctured, its apex red; elytra punctured, membrane dusky, abdomen black above; connexivum red, spotted with black, beneath and logs red, stigmata black.

L. 11-14 lines.

Common by beating, and generally distributed.

ASOPINA.

(i) 1. Sides of the thorax in front rugose or roughly tootherl.

(3) 2. Anterior femora toothed leneath . . . Prcromerus.

(2) 3. Anterior femora simple.

(5) 4. Posterior angles of pronotum produced into lobe-like processes ; second aluhminal seg-

ment with a spinose process at the hase
(1) i. Posterior anigles of pronotum and second ablominal segmed simple. Asopts. 
(1) 6. Sides of the thorax simple throughont.

(8) 7. Anterior femora toothed beneath . JALL.

(7) 8. Anterior femora simplo (insect steel-blue or green) . . . . Zicrora.

\section{PICROMERUS, A $\mathrm{m} . \mathrm{S}$.}

A genus easily distinguished by the spine-like posterior angles of the pronotum, together with the dentate anterior femora; the anterior tibiw also lave a small spine behind, just beyond the middle. There are several European species, but we have only one in this country.

P. bidens, Limn-Bronzy-brown, deeply punctured with black, some of the interstices reddish; antenua and legrs red, pronotal spines black. Head bronzy-brown, central lobe reaching the front margin; pronotum with its lateral margins narrowly red and rugose, diverging in nearly straight lines to near the middle, when they diverge more rapidly and form two large spine-like angles; base produced, its scutellar angles acute, disc strongly punctured; scutellum and elytra strongly punctured, the apex of the former and two small callosities at its basal angles red; abdomen bronzy above, red-brown or red beneath, legs slightly pilose, spines of anterior femora and tibiæ black.

L. 12-14 $\mathrm{mm}$.

Wimbledon, Cholham, Reigate; Battle, Dallington Forest, Netherfield amongst Culluna, Butler; Esher, Weybridge, Headley Lane, Loughton Esser, Billups; Dublin, AIcNab; Chatham, Champion; St. Ives, MLason; Glanvilles Wootton, J. C. Dale; Whittlesen MLere, C.W. Dale.

\section{PODISUS, H.S.}

There is only one European species of this genus, which is easily characterized by the lobately produced posterior angles of the pronotum and the spinose process of the 
second abdominal segment; in this respect it approachos to Troproris, but its stont rostrum and short antenno will at once distinguish it from that gous.

P. Iuridus, Fab.-Ochreons with green reflections, fourth joint of the anteunce orange-yellow at the apex, sides of the pronotum lobately produced posteriorly; legs testaceons, spotted with black. Hend green, with purplish reflections, deeply punctured, margins raised, central lobe shorter than the cheeks, free in front; pronotum with the lateral margins widely green, edges rugose, produced posteriorly into two rounded processes, projecting considerably beyond the sides of the elytra; disc deeply punctured, the punctures closer and more rugose towards the sides; scutellum and elytra ochreous, deeply punctured with green or black, the irregular grouping of the punctures giving a somewhat mottled appearance; membrane dusky, with coppery or purple reflections; abdomen blue-black above; connexivum green, spotted with orange; beneath and legs ochreous, sprinkled with black or green spots; legs pilose, anterior tibia with a black spine posteriorly, tarsi nearly black.

L. 10-12 $\mathrm{mm}$.

Not common, Bromley ES; oft" birch, Norfolk, Elwards; Chertsey, Weybridge, Headley Lane, Margate, Billups; Battle, Inutler; Glanvilles Wootton, 'Tenby, Dule; Knowle, Burmouth, Wicken Feu, Chobham, St. Osyth, Bilutch; Darenth, Caterham, Champron.

\section{ASOPUS, Burn.}

This genus, formerly known in our lists under the mame of Rhucognathus, las only one representative in Europe; it is very distinct from any of our other gener, being most closely allied to l'orlisus, but separable at once by the simple angles of the prouotum, the shorter more convex 
form, the long apical joint of the antennx, and the largely rounded apex of the scutellum.

A. punctatus, Limn.-Ochreous or brownish, varying to green or purplish, densely punctured with green or purplish punctures; angles of thorax slightly prominent ; antenne black, tibire banded with yellow. Head green or purplish, sides sinuate; pronotum with the lateral margins rugose in front, posterior angles produced beyoud the sides of the elytra; base, across the scutellum, nearly straight; dise deeply punctured, more closely so near the sides, dorsal line pale; scutellum and elytra deeply punctured, the apex of the former largely rounded, almost half as wide as the base; membrane black, abdomen above blueblack; connexivum spotted with yellow, underside varying from pale ochreous-yellow with black punctures to purplish-blue; legs bronzy-green or purplish, each of the tibia with a central pale band.

L. $7-9 \mathrm{~mm}$.

A very variable species in colour, some specimens being nearly of a bronzy tint throughout. Mousehold Heath, Norwich, Eclwards; Eastbourne, Butler; Weybridge, Headley Lane, Loughton Essex, Billups; Wimbledon Common, in moss; Budleigh Saltertou, J. C. Dale; Bournemouth, C.W. Dale; Cannock Chase, Blutch; Loch Rannoch, Marshall; St. Ives, MLuson; Southampton, Mickleham, Esher, Leith Hill, Champion.

\section{JALLA, Itahn。}

The species representing this genus in Britain is one of our greatest rarities; it may be known generically by its stout rostrum, the smooth simple sides of the pronotum and the toothed anterior femora and tibix.

J. dumosa, Limn.-Dark brownish red, more or less marked and suffused with black, legs black, tibio with a 
red central band. Head black, finely punctured, with a raised central red line, antenna black; pronotum with the lateral margius slightly curved, obtusely raised, smooth, and red, posterior angles not produced; disc dull reddish, with very large scattered black punctures, the anterior portion of the pronotum and the sides within the red lateral margins are black, slightly impressed and closely punctured, there is a smooth red dorsal line in front; scutellum closely punctured, black, dorsal lime and a spot at each side of the base, red; elytra closely and finely punctured, brownishred; abdomen above and beneath black; connexivum at tho edge red, the red colour produced above into a small spot on each segment; legs black, each tibia with a wide red central band; auterior femora with a tooth towards the apex; anterior tibia with a thorn-like tooth posteriorly.

L. $11-12 \mathrm{~mm}$.

Deal, one in larval condition; taken also by Dr. Powel".

\section{ZICRONA, Am.S.}

Generically allied to Jalla, but very different in goneral aspect; the steel-blue colour aud small size would distinguish it easily enough ; but the chief generic characters are the simple anterior femora and the shining smooth surface of the entire insect.

Z. carulea, Linn.-Entircly of a steel-blue or bluegreen colour, smooth aud shining, central lobe of the head raised posteriorly and depressed in front, not enclosed by the cheeks, antennw black; monotum rather largely punctured, the sides straight, the posterior angles rounder, projecting slightly beyond the sides of the elytra; scutellum and elytra punctured, membrane black, anterior tibio with a small spine-like tooth posteriorly.

I. $6-7 \mathrm{~mm}$. 
Wimbledon Common; Micklehnm, Chilworth under Junipers, Netherfield amongst Calluna, Battle amongrst Mentha hirsuta, Dallington Forest, E. A. Butler; Ventnor on hill side amongst grass; Headley Lane, Horsley surrey, Billups; Devon, Parfitt; Glanvilles Wootton, J.C. Dale; Chatham, Canterbury, Higham Kent, Woking, Champion; S'rwansea, Blatch; Ambleside, Land's End, C.W. Dale.

\section{ACANTHOSOMINA.}

\section{ACANTHOSOMA.}

As in Pentatoma I have included under this genus what the Continental authorities refer to three different genera; these I have treated as sub-genera, feeling that in our limited fauna it is better, unless the generic distinctions are very strong, to restrict the number of genora as much as one reasonably can-the two-jointed tarsi will at once distinguish this genus from all the other British genera of the Pentatomida, the strongly-developed vertical plate of the mesosternum and the carinated abdomen, with the long spine on its second segment, are also characteristic of the genus. The care shown by the female parent of A. griseum for its young has been pointed out by De Geer, and verified comparatively recently by the late Rev. J. Hellius of Exeter, who, in the "Entomologist's Monthly Magazine," vol. vii. p. 53, and vol. xi. p. 42, gives interesting accounts of his observations. He observed a female laying eggs on the underside of a birch leaf, about the 6th June; sho laid about thirty to forty eggs in a diumondshaped batch; under the microscope an egg appeared "long in shape, trvice as long as wide, plump, a little depressed on the sides, reticulated all over very faintly, somewhat glossy, and in colour pale whitish-green." The mother took her stand over these eggs, but Mr. Hellins did not think that her body touched them. On the 29th Juno 
he "found the young bugs all hatched, and clustered under thoir mother amongst the empty egg-shells; they were yellowish-green in colour, their thoraces becoming darker than their abdomens;" and he "saw them moving their antenna." On 3rd July he "found them showing a red streak down the middle of the abdumen, and on the Gth they had moved away from the egg-shells, and wero got together by themselves." On the 9th he "found them moulting, and saw some of them kicking arvay their cast skius behind them: their colours were bright at first, yellow with vermilion stripe, and they soon began to move about more freely, and on the 13th migrated, now with sadly diminished numbers, to a neighbouring catkin." Mr. Hellins says that he then despatched the mother, with eight young ones, to Mr. Douglas, and I believe I have some of the actual specimens now before me; they are, of course, a good deal shrivelled up and are scarcely more than $1 \mathrm{~mm}$. in length; the rostrum projects considerably beyond the apex of the abdomen, and the mandibles and palpi are projected in front. Whother this has been done artificially or whether in the young state these are free from the rostrum I am unable to say. I am not aware that similar habits to those given above have been noticed in any other genus or even species.

(6) 1. Ist joint of anteuna reaching distinctly beyond the alex of the heal.

(5) 2. Oritice of the ouloriferons sac terminating exteriorly in a long transverse furrow connexivum not spotted.

(sulig. Acanthosoma.)

(4) 3. Angles of pronotum much produced - Iryorrioid LE.

(i) 4. Angles of pronotum searcely proklueel. DENTatua.

(2) 5. Oritice of ocloriferous sac short; contuexivam spotted. (subs. Elasmostethus.) IxтERstinctü.

(1) 6. Ist joiut of antennive not reiaching or scarcely reaching leyond the apex of the head. (Subg. Cyphostethus.)

TRISTRIATUM. 


\section{(SodGenus ACANTHOSOMA.)}

A. hæmorrhoidale, Linn.- Shining, ochreous or greenish, with a slight reddish tinge in places, largely and remotely puuctured with black; antenno black, except at the base, angles of pronotum much produced and dark at the apex. Head pointed, central lobe narrow, produced to the apex, cheeks punctured; antenne with the basal joint elongate, pale, the rest dusky, darkening to the apex; pronotum very remotely and largely punctured with black, sides nearly straight in front, posterior angles produced into semi-acute processes, which are nearly black at the apex; scutellum very remotely punctured, apex very narrowly produced into an impunetate process; elytra more closely and finely punctured, membrane smokybrown, abdomen above red at the apex; beneath and leg's pale, mesosternal plate not extending to the intermediate coxiv.

L. $13-15 \mathrm{~mm}$.

Abinger, Hastings, Battle, E. A. Butter; Devon, common, $P$ urfitt; Lincolnshire, Well Vale on Huwthom, $J . E$. Mition; Norfolk, Eclwards; on Birch, Headley Lane, Horsley, Surrey, Billups; Armagh, Ireland, one specimen in May, 1888, Rov.W.F.Johnson; Bath, Bluthureyt; Glanvilles Wootton, Tenby, Dule; Knowle, Caunock Chase, Blatch.

A. dentatum, De G.-Shining, ochreous or greenish, more or less suffused with carmine red, deeply and largely punctured with black, posterior angles of the pronotum slightly produced, rounded. Head ochreous, central lobe produced to the apex, where it is rounded, cheeks with a fer scattered punctures; antennæ pale, fourth and fifth joints dusky; pronotum largely punctured with black, greenish, or ochreous when faded, its base more or less red, the apex of the posterior angles black, sides slightly concave, posterior angles rounded, projecting slightly beyond 
the sides of the elytra, base simuate across the scutellim, anterior margin with a row of punctures parallel to it, behind which is a smooth transverso elevation. Scutellam punctured as the pronotum, greenish with a red tiuge towards the base, apex narrowly pointed; elytra rather more fincly aud closely punctured than the scutellum, red, the disc more or less green, membrane slightly dusky, with a dark spot on tho outer margin and a more or less dark cloud extending from it across the cntire width of the membrane; abdomen above black, connexivum ochreons, produced at the apex into a projecting ancle beyond the central part of the abdomen, apex of the abdomen red above and beneath, the rest of the underside ochreons; stigmata black, legs ochreons, aper of trasiblack; mesosternal plate extending posteriorly a little beyond the intermeriate coxio.

L. $8-10$ mun.

Birch and other trees, Norfolk, Elumets ; Shirley, Plumstead, Reigate, Billups; Hastings, Butler; Armagh, Juhnson; Glanvilles Wootton, Purley Heath, Dale; Knowle, Brandon, Barmouth, Humstantou, Blateh; Forres, Norman.

\section{(SUBGENCS ELASMIOSTETHUS.)}

A. interstinctum, Iinir.; (griverm, anet. nec Linn.)Shining, ochreous, more or less red towards the margins, strongly punctured with black, connexivam spotted with black. Ifead with the central lobe projecting as fir as the cheeks, largely puucturud with black, anteune pale, with the terminal joint black at the apex; pronotum with the anterior angles slightly produced laterally, sides nearly straingt, posterior angles produced but not acutely, base sinuate across the scutellum, surfaco largely punctured with hlack, disc much raised posteriorly; scutellum punctured, chelirous, with a black cloud across the base; elytra rather 
less strongly punctured than the scutellum, membrane nearly In yaline ; abdonen above black, connexivum red with narrow black bands; beneath and legs ochreous red, thorax punctured with black, stigmata black, mesostermal plate extending backwards beyond the intermediate coxi.

L. $8 \mathrm{~mm}$.

On Birch trees (for habits of mother and young, see generic description), generally distribinted.

A closely allied species, "Fieberi," occurs on the Continent, which may be known by the black antennæ and the strongly produced anterior angles of the pronotum.

\section{(Subgenus CYPHOSTETHUS.)}

A. tristriatum, Linn.-Shining, punctured, green, clavus and the corium inwardly and apically blood red, thoracic angles simple, antennse ochreous. Head rather finely punctured, central lobe rather broad, extending beyond the cheeks and rounded at the apex, antemma reddish ochreous, the apex darker; pronotum rather largely punctured, anterior margin very slightly sinuate, sides nearly straight, posterior angles projecting slightly beyond the margins of the elytra, base across the scutellum slightly sinuate; scutellum largely and remotely punctured, with a smooth slightly raised dorsal line; elytra punctured rather closely along the external margin, and on the clavus, but with an clongate impunctate very shining region near the middle; posterior margin of the corium rounded, membrane hyaline, with a small brown patch just below the centre of the posterior margin of each corium and an irregular narrow transverse clond beyond it; abdomen black abore, with the apex widely, and connexivum pale, the latter terminating on each side in an acute angle; beneath and legs greenish, tarsi piccous. 
I. $10 \mathrm{~mm}$.

Jumiper bushes, Boxhill and Mickleham, Cisbury near Worthing; Weston, J. C. Dale; Newcastle, Wailus.

\section{COREID瓜.}

Species very variable in form, frequently with the pronotum and the connexivum more or less laterally produced, antenue stout, with the terminal joint usually thicker than the rest, and the basal joint in the Coreina strongly developed, antenniferous tubercles strongly developed; antenus inserted above an imarinary line drawn along the side of the head from the centre of the eye to the apex of the central lobe of the face; pronotum often produced and raised at the postero-lateral angles; scutellum of medium size, elytra consisting of corium, clavus, and membraue; membiane witl numerous nervures, frequently branching from a common nerve running parallel to the apical margin of the corium. Connexivum in the Coreina nsually more or less dilated and raised.

The exponents of this family are vegetable feeders and most of them may be taken by sweeping; but some, such as Psendophlecus, etc., live under low-growing plants in sandy places.

\section{TABLE OF SUBFAMILIES.}

(6) 1. Orifice of oloriferous sac very distinct, often auricular in form, not hidden between the intermediate and posterior

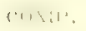

(5) 2. Cheelis not prodused beyond the central lolve of the fiace.

(4) 3. Apical joint of the antenno short. Corersa.

(3) 4. Apical joint of the antemun very long

(i) 5. Cheels produced beyond the centrai

(1) 6. Orifice of orloriferons sac indistinct or
hisken between the intermediate und posterior $\cos x$. . . Conzixa. 
COREINA.

(12) 1. Antenniferous tubercles with an external spine or prominence at the side.

(7) 2. Scutellum impressed at the base, and with a distinct dorsal carina.

(4) 3. Pronotum nearly as long as wide

(3) 4. Pronotum much wider than loog.

(6) 5. Sides of the pronotum rugose and more or less spinose . . .

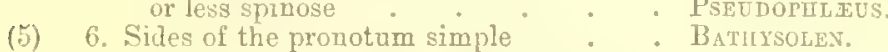

(2) 7. Scatellum simple.

(9) 8. Surface of insect hairy, sides of pronotum

spinose Coreus.

(8) 9. Surface of insect not hairy, siles of pronotam simple.

(11) 10. Antenniferous tubercles with a strong external spine . . . .

(10) 11. Antenuiferous tubercles not spinose.

(1) 12. Antenniferous tubercles without an external spine or prominence.

(14) 13. Head with two converging spines between the antenna

Spatiocera.

Psetnoretims.

Exortors.

Ceraleptos.

Srromastes.

(13) 14. Head simple between the antenur.

(16) 15. Conuexivum strongly and angularly dilated in the miclde

(15) 16. Connexivum not angularly dilated in the mildle. . . Goxocerus.

SPATHOCERA, Stein.

A genus of few species, much resembling each other in form, but differing in the form of the antennæ, pronotum, etc. We have only one species in this country; they occur in sandy places and are all more or less local and uncommon; the elongate pronotum with its sharp lateral margins and the deeply impressed scutellum at the base will distinguish it from all the other genera of this section.

S. Dalmanni, Schill.-Dull brown, subrugose. Head bearing numerous tubercular spines, central lobe of the face at its apex somewlat spatulate, antenniferous tubercles large and angularly produced, basal joint of the antenno triquetrous, much thicker than the rest; second joint about half the length of the third, third slightly dilated and black at the apex, fourth black, ovate; pronotum with the 
anterior margin about half as long as the base, its angles produced forwards, sides sinuate, paler than the disc, posterior angles slightly raised, base lobately produced on cach sile alove the corium, straight across the base of the scutellum, disc granulately rugose in front, with two slight longitudinal impressions; scutelium deeply impressed and dark at the base, with a pale dorsal carina dividing the impression; nerves of the corium rather strongly raised, sides of the connexivum slightly rounded, its surface meven, apex of the abdomen rounded in the $\sigma^{*}$, in the o the apex of the connexivnm is abruptly truncate, and then follow the two narrower genital segments, of which the apical is much narrower than the preceling; underside slightly paler than the upper, freckled with darker spots; legs brown.

L. $5-6 \mathrm{~mm}$.

Rare, Weybridge in moss, Douglus and Scott, and Power; Reigate Heath; Deal, Fillups.

\section{ENOPLOPS, Am. S.}

A genus of few species, casily known from its allies by the spiniform antenniferous tubercles, and the broadly dilated connexivum; in the $q$ the sixth dorsal segment is largely and angularly emarginate, showing the two genital segments, which are much narrower than the sixth, the apical one being deeply cleft; in the $\delta$, the apex of the abdomen viewed from above is subtruncate and just shows the genital segment beyoud, which is formed like a deep cup. We have only one species in this country.

E. scapha, $l_{a}^{\prime} b$.-Dark brown, dull, closely punctured with black, head covered with small white rugosities, looked at from above, produced in front into a pointed process, sides of the head in front of the eyes pale, as are also the spiniform tubercles, antennic with the larsal joint thick, 
slightly curved, rugose and coloured like the hend, secoud and third joints red, fincly rugose, the latter darlser and somerwhat prismatic at the apex, apical joint oblongovate, dark; pronotum much raised and widened behind, punctured and more or less rugose, anterior margin abont a third as long as the base, sides narrowly pale and rugose in front, deeply sinuate, raised and rouncled posteriorly with a slight indication of a posterior angle, base rounded; scutellum finely rugose; elytra punctured, each puucture with a slight rugosity at its side which bear's a short hair; connexivum widely dilated, with a pale spot on each segment; disc of the abdomen above yellow, the rest black; beneath ochreous, punctured with black, legrs with the femora brown, tibia ochreous, spotted with black.

L. 11-12 $\mathrm{mm}$.

Folkestone, Scarborough, Charmouth and 'Tenby, Newcastle, Douglas and Scott; Sandown, Butler; Sandwich, Cowbridge S. Wales, Billups; Ventnor, Chumpion; Falmouth, Dule; Isle of Wight, Blutch.

\section{SYROMASTES, Latr.}

Of this genus there is, I believe, only one European exponent, which may be easily known by its broad form, its wide pronotum, which is almost as wide as the abdomen in its widest part, and the two convergent spines between the antennx; genital segments as in Lhoplops, but completely hidden in the $\delta$ by the preceding dorsal segment, and shorter and of more equal width in the $q$; it is generally a tolerably common insect in autumn, and occurs by sweeping.

S. marginatus, Iin.-Dull brown, finely punctured with black. Head with the antenniferous tubercles simple externally, but each bearing a spine on their inuer margin, which converge and almost touch at their apices, face 
beyond the antennw nearly vertical ; antenne fincly rugose, with the basal joint long, thick, and-slightly curved, second and third narrow and red, fourth brown except at the extreme base, which is red; third joint obliquely truncate at the apex; pronotum much raised posteriorly, antorior margin straight, about a quarter the length of the widest part of the pronotum, sides slightly sinuate in front, raised and rounded just before the postero-lateral angles, which are distinct but obtuse; base largely produced, nearly straight across the scutellum; disc slightly concave in front, and with a curved raised transverse line just abovo the base; scutellum simple; elytra finely punctured; connexivum broad and reflexed, with a slightly paler spot on each segment; disc of the abdomen black at the base, red beyond the middle; bencath ochreous, punctured with black, legs with the femora punctured with black, and with two rows of very short black spines beneath, tibie pale, tarsi redilish.

L. 14-15 $\mathrm{mm}$.

Generally distributed in the South of England, but not recorded from Norfolk; Cardiff, Biillups: Barmonth, Blutch.

\section{VERLUSIA, Spin.}

Of this genus our one representative is not likely to be confounded with nny other, the almost diamond-shaped abdomen being peculiar as a generic character; the abdomen is widest at the fourth segment, from which it narrows to the baso and apex, its sides converging both ways in almost straight lines; genital segments much as in Syromastes, the male segment being hidden from abovo.

V. rhombea, $I_{i}$ in.-Pale brown, with a darker puncturation. Head with the eyes close to the anterior margin of the pronotum, autenniferous tubercles simple, head 
between the antenur, looked at from above, produced into a pointed process; antenue with the basal joint thick and slightly curved, second much thinner, slightly tapering from the base, third narrow and parallel sided, reddish like the second, fourth darker, ovate, red at the extreme apex; pronotum slightly raised posteriorly and at the sides; sides nearly straight, posterior angles acute and produced, base produced, slightly sinuate across the scutellum, with a raised line just within it; scutellum simple, and punctured like the elytra; connexivum largely and angularly produced at each side, unspotted; disc of abdomen above, ochreous with numerous black spots, arranged in three indefinite longitudinal series; beneath pale ochreons, sparsely punctured with black; legs ochreous, simple.

L. $10 \mathrm{~mm}$.

Woking, Chobham; Gomshall, Butler; Darenth, Caterham, Esher, Champion; Whitesand Bay, Plymouth, J. $J$.Walker; Deul, Douglas; Manaton and Exeter, Devon, Parfitt; Glanvilles Wootton and Bournemouth, Dale.

\section{GONOCERUS, Lutr.}

Elongate, head simple, without spines, antennæe long, pronotum with the posterior angles produced and acute; connexivum narrow, genital segment of $\delta$ hidden from above, those of the of gradually narrowing to the apex, which is bifid. Our one British species occurs on the Brox (Buxus sempervirens'), on the Continent it occurs on other plants. There are two other European species, one occurring on Juniper, the other on Arbutus and Mustick.

G. venator, Fab.-Pale reddish brown, punctured with black punctures, head simple, the central lobe slightly longer than the cheeks, antenna with the basal joint of the same colour as the head, and finely rugose, slightly thickened and curved, second and third joints red, fourth 
darker, about half as loug as the third; pronotum considerably raised posteriorly, especially at the angles, sides sinuate, margins finely rugrose, posterior angles produced, acnte, base prodnced, slightly sinuate across the scutellum, and with a strongly raised line parallel to it; scutellum faintly winkled transversely; connexivun ouly slightly produced laterally, evenly rounded to the base and apex, disc of abdomen above black, with a pile central spot and palo at the apex; beneath and legrs pale ochreous.

T. 11-12 $\mathrm{mm}$.

On Box-trees at Boxhill Surrey.

\section{PSEUD0PHIßUS, Iиrm.}

A very distiuct genus, which may be known at once by the tubercular surfice of its head and pronotum; the basal joint of the antemue is short and thick and very rugose; the anterior cora in the of have a spinose tooth posteriorly, the genital segments are shaped much as in the preceding genus. The posterior femora in our British species are simple; there are two other European species, but they are both from tho South, and therefore not likely to occur in England.

P. Fallenii, Schill.-Greyish oclureous, very rugose, irregularly mottled with black. Head very rugose and tuberculous, antenuiferous tubercles large, blunt, basal joint of the antenue short, about one half as long as broad, very rugose, second and third thin and finely grannlated, fourth ovate, black; pronotum much raised posteriorly, lateral margins tuberculously spiuose, deeply simuate, posterior angles largely rounded, with their margins reflexed and rugose, base nearly straight across the scutellum, with a strongly raised line on the dise just within it; dise with three interior impressions, of which the centre one is the deepest and best defined, and in which are some short erect black spines, tho interstices of these impressions run up as 
ridges on the punctured posterior portion of the dise; scutellum punctured, with a pale dorsal ridge and margins; elytra punctured, nerves much raised, spotted with black, membrane hyaline, with small black spots on the nervures; connexivum wide, slightly raised, with darker brown bands; abdomen pale on the disc, legs brownish, tibia paler.

L. $7 \mathrm{~mm}$.

Deal; Braunton Burrows, Devon, Curtis; Freshwater Bay, Pembrokeshire, Marshall; Brandon, J. J. Wallier; St. George's Hill, Weybridge; Taff's Wells, near Cardiff, Billups.

\section{BATHYSOLEN, Fiel.}

This genus, of only ono species, is closely allied to Pseudophlceus, but may be known by its having the lateral margins and surface of the pronotum simple, and the front corre simple in both sexes; the posterior femora are spinose at the apex.

B. nubilus, Fall.-Brown, rugosely punctured. Head finely rugose, antenniferous tubercles large and blunt, basal joint of the antenuæ short and stout, finely rugose, second and third joints thin, very finely granulated, fourth joint ovate, black; pronotum transverse, lateral margins nearly straight in front, rounded posteriorly, with a slight tooth indicating the posterior angles; baso produced, its posterior margin nearly straight; disc nearly flat, finely rugose and punctured, with a curved, raised line near the base; scutellum foveated at the base, with a central carina at the apex; elytra deeply punctured, the nerves much raised; membrane smoky; connexivum dark, with narrow, paler bands; abdomon abovo reddish, beneath reddish ochreous, more or less mottled with darker colour; legs with the tibia pale, posterior femora with a short sharp spine near the apex.

I. $6-7 \mathrm{~mm}$. 
Very rare, Deal, Douglus and Scott; I have a specimen ex Iturling', Collection, probably from Deal; Hr. Lducurls records two specimens from Norfolk, one taken by $M r . F$. Norifute and the other found dead by himself "at the roots of grass in a lane off Unthanks Road," Norwich.

\section{CERALEPTUS, Stein.}

This genus may be known by the subequal first and second joints of the antenne, the straight denticulate sides of the pronotum, and the group of spines near the apex of the posterior femora. There are two other Furopenn species, both of which are meridional.

C. lividus, Stein (squatidus, D. and S.).-Ochreous, punctured. Head finely rugose, with a black stripe on each side, in which the eye is situated, antenniferous tubercles small and only slightly promineut, central lobe of the face wide, longer than the cheeks, basal joint of the antenna brownish, elongate, finely rugose, and slightly curved, second about equal to the first in length, red, third and fourth dark, except at the extreme base of the former; pronotum trapezoidal, sides dark or black in front, lateral margins nearly straight, denticulate in front, posterior angles simple, base slightly produced, nearly straight; disc flat, gradually raised to a line just within the base; dorsal line impressed and smooth; scutellum that, punctured; clytra punctured, membrane with the nerves dark; connexivum raised, mottled with darker brown and with pale transverse bands; abdomen above and benenth pale; legs pale, apex of posterior femora darker, and with a group of three or four spines beneath, of which the basal one is much the longest and slightly curved, on the basal side of this group is another small spine; tibic and tarsi pale, slightly darker at the apox.

L. $8-10 \mathrm{~mm}$.

Deal Sandhills, Powei and Domples; Chattreten Kent, 
Champion; Chobham, by sweeping, Billips; Camber Sandhills, Collett.

COREUS, Fab.

The species of this genus are very closely allied and difficult to determine, but we have only one in this country, and the generic characters are so well defined that there is little chance of confusing it with any other British species. The entire insect above is more or less hairy, all the joints of the antennæx are thick and bristly and of nearly equal width, the sides of the pronotum are armed with a row of long pale spines, and the posterior femora have a group of spines near the apex. The species are found by sweeping, \&e.

C. denticulatus, Scop.-Reddish brown, hairy and punctured. Head rugose, antenniferous tubercles produced, but blunt; joints of the antennx rugose and lrairy, the hairs bristly and erect, basal joint very slightly thicker than the rest, apical joint elongate ovate, black; pronotum with the sides very slightly sinuate, armed with a row of white spines, posterior angles acute, spinose, base produced, its short lateral margin between the posterior angle and the base of the elytra spined like the sides of the pronotum. in front of the angles, basal margin with a spine on each side of the scutellum; disc flat, rugosely punctured, gradually raised posteriorly, and with a transverse carina situated just within the basal margin; scutellum flat, punctured, slightly raised; elytra rugosely punctured, and with a few slightly darker spots on the raised nerves; membrane slightly smoky, nerves with longitudinal dark markings; connexivum slightly reflexed, rest of the abdomen above red, base and a small elongated narrow apical spot black, beneath ochreous red; legs brown, mottled, posterior femora with a group of spines near the apex, of which the basal one is the longest, and with a single spine nearer the base. 
L. 7-8 $\mathrm{mm}$.

Woking, Deal, Ilfracombe; Folkestone, Rye; Plumstead, Darenth, Caterham, Champrion; Glanvilles Wootton, Portland, Bournemonth, J. C. Dale; Haldon, Devon, Purfitt; Knowle, Bewdley, Tonbridge, Isle of Wight, Rlatch; Margate, Oxshott, South Hayling, Billups; Hastings, $E$. A. Butler; Mousehold Heath, Norfolk, Elwarts.

\section{ALYDINA.}

\section{ALYDUS, Fal.}

A very peculiar genus, which may be at once known by its somewhat elongate form, prominent eyes, and long curved apical joint to the antenne, which in our British species is almost as loug as the second and third together; the clavus is very short, and the apical margin of the corium is very long; the connexivum is not dilated, and the posterior femora are very long, and armed beneath with several spines; male genital armature visible from above, the genital segment being open posteriorly. There are only two European species of this genus, of which we have one in this country.

A. calcaratus, Linn.-Brownish-black, clothed with short erect black hairs. Head with the eyes situated at some distance from the pronotum; no distinct antenniferous tubercles; antenna with the second and third joints testaceous, except at their extreme apices; ocelli very promineut; pronotum slightly widened behind, with its front and side margins nearly straight; posterior angles rounded, base slightly produced, with an emargination opposite the scutellum; disc punctured and finely rugose; scutellum punctured, produced to a sharp point at the apex; corium and clavus brown, punctured with black, nerves very prominent; membrane dusky broww, with numerous wavy nervures, springing from a strongly curved basai 
nerve; abdomen above bright red in the centre; connexivum narrowly reflexed with a pale spot at the base of each segment; beneath bronzy brown; legs pilose, tibire except at the base and apex, and the base of the metatarsi testaceons; posterior femora with four spines equidistantly placed, and two or three smaller ones near the apical spines.

L. $12 \mathrm{~mm}$.

In heathy places, often in company with Formica rufa, which the larva greatly resembles. Woking, Chobham; Esher, Weybridge, Leith Hill, Champion; Barmonth, Bhatch; Monsehold Heath, Norwich, Elwards; Bolt Head, Devon, I'triftt; Parley Heath, Bournemouth, Dale; Shalford and Ervhurst, Butler; Purfeet, on a weedy bank, Marstuall.

\section{STENOCEPHALINA.}

\section{STENOCEPHALUS, Lat :}

Head small and narrow, parallel-sided behind the eyes, antenniferous tubercles distinct, cheeks produced at the apex and pointed, much longer than the central lobe of the face; antenne with the apical joint long and curved; elytra slightly widened beyond the middle, posterior femora simple; malo apical segment visible from above.

A genus of very closely allied species, and very similar to each other in general facies. We have only two species in this country.

(2) 1. Second joint of the antennx with a black ring in the centre, membrane with dark spots between the nervures; antenna and legs with short, decumbent hairs . . . . . AGILIs.

(1) 2. Second joint of antenne not ringea in the centre, membrane witbout dark spots, legs and antenna with longer erect hairs - NEGLECTUS.

S. agilis, Scop-Ochreous-brown, punctured with black, ciothed with very short rather scattered black hairs. 
Head elongate parallel-sided, eyes situated abont the midile of the sides, cheeks produced, pointed in front; basal joint of the antenua black, slightly curved and thickened; second yellow, black at the apex, and with a central dark ring; third widely black at the apex; fourth nearly twice as long as the third, black, pale at the extreme base; pronotum with the anterior margin narrow, not half the width of the base, lateral margins straight, posterior angles simple, base nearly straight; disc Hat, punctured, darker in front; scutellum punctured, extreme apex pale, raised and slining; elytra flat, punctured, behind the middle slightly broader than the pronotum in the $\sigma$, decidedly so in the + ; membrane brown, with numerous nervures branching from two nerves emanating from the apical margin of the corium, which unite on the disc of the membrane, enclosing a basal cell, tho corium has a small white spot at the starting-point of the nerves; between the nervures of the membrane are numerous small darker spots; comnexivum reflexed, spotted with yellow; abdomen red above within the comnexisum, reddish brown beneath; legs hairy, base of the intermediate and posterior femora and all the tibia except at the extreme base and apex red, or yellowish.

I. $12-13 \mathrm{~mm}$.

Chobham, Combridgo S. Wales, Billups; Esmouth and Studland, Lale; Braunton Burrows, N. Devon, Iarfitt; Redhill, Surrey, J. Limncll; Bewdley, Isle of Wight, Blutch; Hollington, Susser, Collett; Folkestone, Rye; St. Ives, Cornwall, Mason; Darenth, Weymouth, Champion; Ryde, Milford Haven, Comworthy, Marshall.

S. neglectus, H. Schf.-So like tho preceding that it is muecessary to give a detailed description; it differs in having the antenna and legs clothed with longer more exserted hairs, in the absence of the black central ring on the second antennal joint, and in the unspotted membrawe. It is also generally a narrower insect. 
I have never seen a British specimen, but Miessrs. Douglas and Scott record it from the "coasts of Devon;" and C.W. Dale from "Nerv Forest, J. C. Dale."

\section{CORIZINA.}

(1) 1. Fourth joint of the antenna longer and thicker than the third; antenniferous tubercles promineut externally .

(ii) 2. Corium entirely opaque, red, spotted with blick

(3) 3. Corium mare or less transparent in places

(1) t. Fourth joint of the antenne not longer and thicker than the third; antenniferous tubercles not prominent.

(i) 5. Insect not very elongate, antenna hairy . . Mrgmus,

(i) 6. Insect very elongate, antennæ not hairy . Cluorosoura.

\section{THERAPHA, Am. $S$.}

Head short, as wide across the eyes as long, ocelli very prominent, antenniferous tubercles produced at the sides and roumded; basal joint of the antenua short, widest in the middle, apical joint thicker than the rest, slightly longer than the third; pronotum transverse; corium not transparent, nerves not very strongly developed; membrane with very numerous fine parallel veins; colour red and black. There is only one European species.

T. hyoscyami, Limn.-Rugosely punctured, red, spotted with black, clothed with scattered pale hairs. Head with the margins black, leaving a large diamondshaped spot in the middle red; antenne black; pronotum red, transverse, sides nearly straight, a wide anterior band and a quadrate spot near each posterior anglo black; scutellum black, its apex red; clavus black except at its apex; corium red, a spot near the middle and one or two on the claval suture black; membrane smoky brown, its posterior angles black; abdomen above red, base and apex black, beneath red, each segment with three black spots, those on the apical segment confluent; legs black. 
L. $9 \mathrm{~mm}$.

"Caister Marrams on Ononis rare," Payet's Yarmonth ; Teignmouth and Dawlish; Braunton Burrows, Parfitt; Glanvilles Wootton, Portland, Land's Eud, Dule; on Erynginn, Barmouth, and Isle of Wight, Murshall.

\section{CORIZUS, Fall.}

Very like the preceding genus in form; but all the species are of an ochreous or brownish colour, and the elytra are more or less transparent, with their nerves very strongly developed; the membrane is liyaline, and the colon of the abdomen can be seen through it. We have four species, all of which are rare. T'liere are eleven species recogmized as Palaearctic in Dr. Puton's catalogue; several are very variable and have given rise to much confusion in the synonymy.

(2) 1. Posterior margins of the metapleure not sinuate, their exterior angles rounded not produced : is the metapleura

(1) 2. Posterior margins of the metapleura CRASSICORNIS. sinuate, their external angles more or less produced.

(ii) 3. Abdomen abore black with pale markings.

(5) 4. Connexirum with large black spots, tibix with narrow brown rings ? . CAPITATUS.

(1) 5. Connexivum unspotted or with rery small black spots, tilia not ringed. . . PARCMPUNCTATUs.

(ii) 6. Abdomen above orange yellow, with black markings.

maculatus.

C. crassicornis, Limu. (ubutilon Rossi).-Brownish or ochreous, rugosely punctured, antennæe with the basal joint slıort and thick, the remaining three subequal in length, but the apical joint thickened; pronotum with its margins nearly straight, dise with a distinct pale dorsal line; scutellum with a pale dorsal line at the base, its apical margin slightly raised and pale; elytra transparent, the nerves very promiuent and often spotted with black, 
mombrane hyaline; connexivum with black spots, dise of the abdomen above black, with yellow markings, apicul segments yellow with a strongly marked central black line; beneath ochreous, often freckled with reddish or brown; metapleuræe equally punctured all over; legss pale sprinkled with black spots.

L. $7-8 \mathrm{~mm}$.

A very variable species in colour, the larger paler forms used to be considered as a distinct species under the name of alutiton Rossi. Easily known from the other species by the metathoracic characters, the metapleure having their posterior extermal angles rounded and their surface evenly punctured all over.

By sweeping in dry places, Choblam, Reigate, Bournemouth; Deal, Chumpion.

C. maculatus, Fieh.-Reddish testaccous, r'ugosely punctured and clothed with long scattered hairs; a pical joint of the antennæ much longer than the third; pronotum rather longer than in the other species, trapeziform, its sides straight, dise strongly punctured with black, and with a narrow raised dorsal line; scutellum punctured, acuminate; elytra semitransparent, the nerves spotted with black, membrane with small dusky spots; connexivum with a black spot on each segment, disc of the abdomen above yellow with black markings, beneath yellow with a series of black dots down each side, and a central spot on the basal segments; metapleuræ punctate only on their basal portion, their posterior angles produced, and visible from above beyond the sides of the elytra; legs reddish yellow, very finely spotted with black.

L. $6-7 \mathrm{~mm}$.

A very distinct species by its uniform orango yellow colour, and yellow abdomen above.

Very rare. Chobham, New Forest; Dallington Forest, Ewhurst, by sweeping, Butler; Sandwich, Billups; Purley Heath and New Forest, Dule. 
C. capitatus, Fub-Brownish red, with paler markings, and black spots. Head red rugosely punctured, and clothed with fue hairs; pronotum red, rugosely punctured, finely lairy, posterior angles smooth and rounded, disc with a narew dorsal line; scutellum with the apex pale, and with its margin raised at the sides but not at the actual apex, giving the apex an almost bifid appearance; elytra transparent except at the sides and apex, which are red, nerves pale, spotted with black; membrane hyaline; connexivum with broad black bands, disc of abdomen above black with yellow markings; apical segments yellow with a broad black central line; beneath reddish brown, metapleurw red in front and punctured, white posteriorly and impunctate, the posterior angles produced and visible from above, orifice of the olloriferous sic very strongly defined; legs, femora red spotted with black, tibia pale with brown rings, tarsi pale, apex black.

L. $5-6 \mathrm{~mm}$.

Rare. Reigate, Dorking, Herue Bay ; Emluurst by sweeping, Butler; Headly Lane, Taff's IVell, Cardiff, Billup; Glanvilles Wootton, Lulworth, Parley Heath, Dale; Sheppey, Chatham, Chumpion; by sweeping Hypericum rerfoluatum, Nunton and Groveley Wood, Marsall.

C. parumpunctatus, Schill.-Ochreous. Head and pronotum rugosely punctured, the former with a black spot behind near each eye, the latter with its margius nearly straight, and with a raised dorsal line in front; scutellum acuminate, its margins raised; clytra transparent, nerves ochreous, sometines spotted with black, membrane hyaline; conuexivum pale, sometimes with small black spots; disc of the abdomen above black spotted with yellow, beneath reddish ochreous; metapleurn punctured in front, posterior angles much produced, and very distinctly visible from above; legs spotted with black.

I. $5-6 \mathrm{~mm}$.

liare. Chobham, Reigate, Bournemouth, by sweeping in 
dry places; Deal, Billups; Parley Heath, Dale ; Caterham, Mickleham, Esher, Weybridge, Woking, New Forest, Ashdown Forest, Sussex, Chatham, Chempion; Norfolk, Edwards; Musloe, Leicester, Kirby.

MYRMUS, Hahn。

Of this curious genus there is only one Europenn representative. It may be easily known by its flat, somewhat parallel form, and its rough and hairy antennxe and legs; the elytra as a rule are not fully developed, and in the undeveloped form the pronotum is nearly parallel sided, in the developed form it is distinctly widened posteriorly; the antenniferous tubercles are scarcely noticeable, and the second joint of the antenne gradually, but very slightly tapers from the base to the apex ; the apical joint is scarcely thicker than the preceding.

IM. miriformis, Fall.-Of a greenish ochreous colour, more or less marked with brown, or in some undeveloped females bright green when alive, with red markings. Head with the eyes slightly prominent in the $q$, more distinctly so in the $\delta$; central lobe of the face longer than the checks, antenne rough, clothed with erect short hairs; pronotum with the sides slightly raised, straight, posterior angles slightly rounded, base nearly straight; disc punctured and clothed with short hairs, ochreous or greenish with a pale raised dorsal line and often a brown streak on each side; elytra subhyaline, the nerves strong and red; membrane hyaline; in the undeveloped form the elytra are only about twice as long as the scutellum; abdomen above ochreons or green, generally with a central black or red stripe interrupted in the middle, but this stripe is sometimes absent in the o ; beneath and legs ochreous or greenish, the latter rough and clothed with erect hairs.

L. 7-9 mm.

On heaths, \&ce, generally distributcd in the Sonth of 
England; but I have no northern or western localities for it. Smithland IVood, Leicestershire, Murshall.

CHOROSOMA, Curt.

At once recognizable by its very elongate linear flattened form, which is quite mnlike that of any other British genus; the antenuiferons tubercles are quite flat at the sides, the second joint of the antenna, as in Myrmus, is widest at the base and gradually tapers to the apex, the antenno are smooth, and clothed with a very fine inconspicuous pubescence; in the of the genital segments are scarcely visible from above beyoud the somewhat truncate segment that covers them; in the of three segments are distinctly visible, the apical one truncate; tarsi with the basal joint twice as long as the second and third together. There are three I'itlactrctic species, all of which are closely allied.

C. Schillingi, Schml.-Very elongate, pale ochreous. Head with the cyes situated at some distance from the pronotum, central lobe of the face longer than the cheeks, antenna with the first joint about as long as the fourth, second and thind subequal in length, but second thickened towards the base; pronotum punctured, anterior margin and sides nearly straight, posterior angles rounded, base slightly sinuate; dise with a distinctly raised dorsal line met in front by a trausverse raised line; scutellum very narrow, keeled; elytra transparent, nerves pale ochreous, membrane hyaline, reaching to about two-thirds of the entire length of the abdomen; abdomen ochreous above, with a black line tuwards the base, within the connexivum on each side; legs ochreous, posterior femora longer than the tibia, the latter with a dark spot on the inner side of the apex.

L. $15-16 \mathrm{~mm}$.

On Marram grass, etc.; on sandhills by the sea-coast, Lowestoft, Southwold; Deal; Camber, E. A. Butler; Margate, Billups; Exmouth, Studland, Dale; Freshwater bay, I'embrokeshire, Warshall. 


$$
\text { Berytide. }
$$

\section{BERYTIDE.}

A family of delicately-shaped species, with very long antenne and legs, and characterized by having the first joint of the antenme and the femora clavate at the apex; the pronotum also bears three keels in all the species. In the Berytina the head is elongate and the forehead produced in a lobe over the face; in the Met cathine the head is subglobose and the forehead simple.

TABLE OF SUB-FAMILIFS.

(2) 1. Forehead produced anteriorly in a lobe. Berytris.

(1) 2. Forehead simple. Meтасаутнам.

\section{BERYTINA.}

(2) 1. Posterior femora reaching nearly to the apex of the membrane . . NEIDEs.

(1) 2. Posterior femora not nearly reaching to the apex of the membrane . . . Berytus.

\section{NEIDES, Lat:}

Very elongate, ochraceous, vertex of the head produced in a pointed process between the eyes-this process in our British species from a lateral view is subclavate, and elevated towards the apex; eyes situated about midway between the anterior margin of the pronotum and the apex of the process; the central lobe of the face is also produced into a process, which is slightly deflected. The antonna are very long and thin, with the apex of the first joint abruptly clavate; pronotum raised posteriorly in the developed form, flat in the undeveloped. Elytra developed, but the wings often brachypterous; legs very elongate, femora gradually incrassated at the apex. 'There are three European species.

N. tipularius, Limn. (parallelus, Fieb.; depressus, D. and S. $_{\text {. }}$ - - Elongate, ochraceous. Head with the frontal process pointed, if viewed from above, broad and clavate if viewed laterally; antenna with the apical joint black and the club of the first joint dark; pronotum punctured, sides and central line raised and smooth, disc raiscd posteriorly in 
developed specimens; elytra punctured with very strongly raised nerves, its mombranal margin with fon small black spots, membrane very narrow with a central dark liue; femora very long, gradually clavate at the apex; tibire very thin, their extreme apex and the tarsi black.

L. $10-11 \mathrm{~mm}$.

Not common. I have generally taken it casually by sweeping: Woking, Chobham, Reigate; Glanvilles Wootton, Parley Heath, Dale; Esher, Mickleham, Deal, Champion; Freshwatel Bay, Pembrokeshire, MLrshall; Haldon, Devon, Parfitt; Hunstanton, Elwards.

Priallelus, Fieb. (depressus, D. and $S_{\text {. }}$ ) is the brachypterous form of this species.

\section{BERTTUS, $F u$.}

Closely allied to Neilles, but ensily distinguished by the shorter femora, the simple central lobe of the face and the shorter second joint of the anteuna. The first joint of the antenuo is thickened at the base, and then suddenly contracted, which gives the appearance of a separate short basal joint. There are several specios in this country, which have given rise to some confusion on account of their dimorphic nature, the presence of the fully-developed wings, causing a greater posterior development in the pronotum, and the modifications in the form of the menbrane consequent on development imparting a very distinct appearance to the fully-developed forms. We have five British species out of the twelve Palaratic species recorded in Puton's catalogue.

(4) 1. Club of first joint of the antennx black.

(3) A. Apex of femora not black . . . sinor.

(2) 3. Alex of femora black . : : crassires.

(1) 4. Club of first joint of antenure sometimes darkened, but not black.

(4) 5. Frontal process acuminate, viewed from above.

(8) 7. Frontal process very long, more than twice as long as its hasal wilth . . c catrors. 


$$
\text { Berytide. }
$$

(7) 8. Frontal process triangular, not twice as long

(5) 9. Frontal process more or less blunt, vierred from above . . . . . MONTIVAGUS.

B. crassipes, II. Schf.-Ochreous; clubs of the antenne and femora very strongly developed, black. Head raised on each side between the eyes, frontal process viewed from above somewhat blunt at the apex; first joint of the antennae with a very strong black club, second and third narrowly black at the extreme apex, fourth black; pronotum punctured, with the lateral unargins and central keel much raised; elytra widest near the middle, about three times as long as wide, prnctured, its nerves very strongly raised, apex of the coritm black, membrane nearly byaline, with a darker central cloud in the $\delta$; legs with very strong black clubs to the femora, apical joint of the tarsi black.

L. $4-5 \mathrm{~mm}$.

Rare; one species on heath near Fairlight, Butler; Headley Lane, Billups; Glanvilles Wootton, Dale; Hastings, Shirley, Champion; Lowestoft, Edwards.

B. minor, HI. Schf. (cognatus, Fieb. (macr.); commutatus, $D$, and $S$. (brach.).--Larger and narrower than the preceding; second joint of the antenur pale throughout, first joint with the apical club less developed, but black as in crassipes; elytra much longer, at least four times as long as wide in the brachypterous form; membrane wider than the corium in the macropterous form, narrower than it in the brachypterous, with a central brown stripe in the male; femora clavate, but less strongly so than in crassipes, the club only slightly darkened; in the developed form the pronotum is much widened and raised posteriorly; in the undeveloped form it is shorter, flatter, and nearly parallel sided.

L. $6-7 \mathrm{~mm}$.

The commonest species of the genus, gencrally distributed, but never abundant, in moss, etc., in the Sonth of England; Aviemore, Champion. 
B. clavipes, $F$ 'ub.-A longer and narrower species than minor, with a very loug suarply-pointed frontal process; the antenno also are very slender, and the basal joint longer than the anterior femora, wherens in minor it is distinctly shorter; the club is also smaller, and only slightly darkened, not black; the elytra in the brachypterous form do not quite reach to the apex of the abdomen in the $q$, which is quite five times as long as the width of the elytra ; legs very long, the femora gradually clavate at the aper, concolorous, or nearly so, throughout; the apical joint of the tarsi black.

L. $7-8 \mathrm{~mm}$.

Rare. I have never taken it myself, and have never seen the developed form. Whitstable, Champion; Freshwater Bay, Pembrokeshire, Niton, Isle of Wight, Murshall; Reigate, Blutch; Norfolk, Curtis.

B. Signoreti, Firt. (pyomers, licut. (brech.).-Ninch smaller and broader than clavipes, to which it is allied by the pale clubs of the antenno and femora; it is also smaller than minor, from which its pale antemual clubs will readily separate it; the femora are thicker throughont in this species than in the others of the genus, and the club at the apex less marked; in the brachypterous form the membrane is about as wide as the elytra; in the macropterous it is distinctly wider; in the male the membrane has a dark central clond.

L. $5-6 \mathrm{~mm}$.

Not rare. Reigate; Hastings, Fairlight, Hurst Green, Ewhurst, Butle; Mickleham, Billups; Cobhaw, Caterham, Champion; Moray and Perthshire, Normun; Aberdeen, Reuter; Lincolnshire, Mruson; Ridalesdown, Blutch; Mousehold Heath, Norfolk, Elwards.

B. montivagus, Fieb.-A larger species than Simoreti, and easily known from it by its slenderer and more distinctly clavate femora, and also by its blunt frontal process; the membrane is very wide, and marked with dark brown, 
somewhat curved stripes in both sexes; the femoral and antennal clubs are distinctly darkened. The brachypterous form of this species is, so far as I am aware, unknown.

L. 6-6! $\mathrm{mm}$.

Southwold, Woking, Ventuor, Worthing; Micklehım, Reigate, Caterham, Sheppey, Chatham, Champion; Freshwater Bay, Pembrokeshire, Milford, Isle of Wight, and Nunton, Marshall; Weymouth, Blatch; North Devon, Stainton.

\section{ME'TACANTHINA.}

(2) 1. Scutellum with a long curved spine . MEtacantios. (1) . Scutellum simple. . . . Metatropis.

\section{METACANTHUS, Costa.}

Elongate, sides of the head behind the eyes subparallel, vertex much raised and rounded, face very short and subtriangular; antennæ very long and delicate, first joint clavate at the apex, second and third subequal, apical joint short, three to four times as long as wide; pronotum much raised and trituberculate posteriorly; scutellum with a long curved spine springing from its base; clavus of the elytra very short, and the apical margin of the corium very long, the membrane large; legs very long and slender, femora clavate at the apex; the orifice of the odoriferous sac is produced upwards along the metapleura, as a sort of canal, with its sides raised, ending in a blunt process, visible even from above.

There is only one representative of this genus.

II. punctipes, Germ.-Pale ochreous. Head black, shining, more or less piceous posteriorly, antennæ with the first and second joints annulated with black, apical joint black, paler at its extremity; pronotum with the anterior margin raised, especially at the angles, posterior angles tuberculated, black, base narrowly reflexed and sinuate; disc much raised posteriorly, with a black transverse band behind the anterior margin, and a fine central carina terminating 
posteriorly in a black tubercle; scutellar spine pale, membrane liyaline; abdomen ochreous, legs anuulated with black.

L. 4-5 min.

On Ononis, Reigate; Hayling I.; Fairlight, Deal, Butler; Headley Laue, Cardiff, Tillups; Glanvilles Wootton, Lulworth, Dule; Whitsand Bay, J. J. Walker; Freshwater Bay, Pembrokeshire, Braunton Burrows, Devon, Marshall; Barmouth and Isle of Man, Bluteh.

\section{METATROPIS, Fieb.}

Head with a transverse channel between the eyes, vertex in front of it slightly raised; antenna very long and delicate, first joint clavate at the apex, the second shorter than the third, apical joint many times longer than wide; pronotum much raised posteriorly and trituberculate; scutellum simple, with a slightly raised central keel; membrane very large; legs very long and delicate, femora clavate; orifice of the odoriferous sac simple. Of this genus there is only one species.

M. rufescens, I. Schf.-Elongate, testaceous, punctured; antenne palor, first and second joints ringed with black, and the club of the first joint with a black band; fourth joint black, its apex pale ; pronotum much raised posteriorly, with a strong central keel terminating posteriorly in an oblong tubercle, posterior angles raised and tubereulated; scutellum with a raised central keel; clavus very short, apical margin of the corium ver'y long; membrane very large, slightly smoky; abdomen reddish testaceous beneath with the base darker; the thorax and head beneath are black; legs pale ochreous spotted with black, clubs of the femora with a broad brown or black band.

L. $9-10 \mathrm{~mm}$.

Rare, on Ciresulutetianu. Portsmouth, Moncrealf; Glanvilles Wootton, C. W. Dalc; New Eorest, by sweepiug fern, Marshall.

Mr. Moncreaff, E. M. M. viii. 136, states that he found 


$$
\text { Lysaida. }
$$

about two dozen larve on Circece in June, 1871, and took them home and placed them with the plants, which he potted. The next day he saw "some of them with their proboscides buried in the soft flower-buds; " they were full fed by the end of August. They changed their skins three times in captivity; its change of skin is described by him as follows: "As the creature increases in size the skin gets too short for it, and the anal extremity becomes drawn up somewhat over the abdomen; it now fixes itself firmly by its claws to a leaf or stem of the plant, head downwards, the head is bent under, the antenna are laid along between the legs, and the larva appears to forcibly straighten the abdomen, the pressure causing the skin behind the head to split, and the thorax to be protruded through the opening; leg after leg is drawn slowly out, the head and antenno following; the wing-cases and wings are drawn down to their proper proportions, the imago then remains suspended by the last segment; in a short time it extricates itself entirely, but is some time before coming to its proper colour and firmness."

\section{LYG正ID正。}

This is one of the largest families of the Hemiptern and includes a number of genera of very diverse facies. They are mostly ground species, occurring in moss, rubbish, under dead leaves, stones, and various spreading plants; but a few are found by sweeping, and Gastrodes occurs on fir trees.

The antenna are situated below an imaginary line drawn along the side of the face, from the centre of the eye to the apex of the head; the elytra are composed of clavus, corium and membrane, the nervures of the latter being few in number, not exceeding five, except in Pyrhocoris.

The abdominal segments in the of vary in form in the different subfamilies; in the Pyrrhocorina all the segments

$$
\text { F } 2
$$


have their posterior margins straight, or nearly so; in the Cygginu the sixth segment only is emarginate. In the Puchymerina and Arthencinc and bising the fifth segment is deeply emarginate, and the sixth has its centre keeled or divided longitudinally; this central division or keel is doubtless the theoretical posterior margin of the sixth segment, and between its sides lies in some cases the ovipositor. In the Henestwing and Cymina the fourth is slightly emarginate, the fifth deeply, and the sixth as in the other's; in the Heterogustrinu both the fourth and fifth are very deeply omarginate. In the of the terminal genital segment is convex beneath and rounded, or more or less truncato posteriorly; the other segments are straight at the apex or nearly so.

Our British genera may be divided into eight subfumilies.

\section{TABLE OF' SUBFAMILIES.}

(1.1.) 1. Ocelli present.

(5) D. All the abulominal stigmata situater on the connexivum.

(4) 3. Elytra not punctured or only very ob.

(.i) 4. Elytra listinct]y punctured : : COrgerisa.

(i) 5. The stigrata of one or more ablominal segments ventral.

(7) 6. The stigmata of the sixth segment only ventral . Bussixa.

(i) 7. The stigmata of at least the last two abdomival segments veutral.

(1) 8. The stigmata of the fifth and sixth segments ventral, eyes pedicillate . Henestarina.

(8) 9. The stigmata of all or at least of the last three segments rentral.

(11) 10. Cheeks scarcely shorter than the central labe of the face. Artieneina.

(10) 11. Cheeks much shorter than the central lobe.

(13) 12. Membrane without basal cells . Pach merina.

(12) 13. Membrane with basal cells : . .Heterogastrixa.

(1) 14. Ocelli absent . . . . . PYrRliocorina.

$$
\text { LYlitili. }
$$

Species black ank ret, antenniferous tubercles rounded. Lrgaus surecies ochreuns, nutenniferons tubercles angular. . Nrsius. 
LYG正US, l'ah.

We have only one species of this gemus out of the sixteen recorded paliarctic species, and it must be confessed that it is but a donbtful native. It claim to a place in our list rests on only two captures of late years, one taken by the late Mr. Sidebotham at Devizes, in June, 1864, the other by the late Mrr. C. G. Hall, at Dover on the 7th September, 1886. It used to be in the older lists, but it was placed by Messrs. Douglas and Scott in their lists of "Reported British Species," and since re-admitted as native by them on Mr. Sidebotham's capture (E. MI. M. iv. p. 2). I had such doubts myself of its being otherwise than an introduced species that I omitted it from my "Synopsis," but this second capture seems to me to give it a right to be considered at any rate as an "occasional visitant." It cannot be confused with any other British genus of the Lygreita, although it resembles therapha, a genus of the Coreidx, from which its spotted membrane and its eyes, which touch the anterior margin of the pronotum, will separate it at once.

Colour red and black; head short, triangular, eyes touching the pronotum, antenniferous tubercles rounded; pronotum with the sides slightly rounded, disc nearly flat; scutellum simple; elytra parallel-sided; legs simple.

L. equestris, Linn.-Bright red; posterior angles of the head, a bilobate spot in front of the pronotum, and a narrow band along the base, the scutellum, a round spot on the clavus, a ceutral transverse baud on the corium, a spot on each segment of the connexivum, four rows of spots on the abdomen beneath, the antenno and legs black; membrane black; a narrow basal band and a round central spot, its apical margin and a short streak, near the centre of the apical margin of the corium, white.

L. $10 \mathrm{~mm}$.

Very rare. Bath, Ifitford, 1837, fide C.W. Dale; Devizes, 186.1, Sidebollam; Dover, 1886, C. G. IItll. 


\section{NYSIUS, Dull.}

A genus of small ochreous species; eyes prominent, projecting beyond the anterior angles of the pronotum, sides of the head converging rapidly behind them, antenniferous tubercles angularly produced; pronotum trapezoidal; elytra semi-transparent, membrane hyaline; orifice of the odoriferous sac large and surrounded by a swooth clevation. All the species are somewhat closely allied, and some of the continental forms, of which Dr. Horváth records ten, are very bard to separate with certainty.

(2) 1. Scutellum with a pale central keel . . . LINEatcs. (1) Sontellum withont a pale central keel . . . THYæi.

N. lineatus, Cost. (ericce, Boh. nec Schill.; lnumnens, Fieb.; Scotti, Sumnd.).-Ochreous. Head and pronotum strongly punctured with black, with a pale line round each eye, and a pale central lobe to the face; antenno brownish black, paler in the middle; pronotum with a pale raised central line, sides straight, with an impressed line running parallel to them on the disc; scutellum with a raised central keel, punctured; elytra smooth, impunctate, shining, pale ochreous, apex of the corium darter; membrane hyaline; abdomen mottled with blackish bromn, legs ochreous spotted with black.

L. 4-5 $\mathrm{inm}$.

On heaths, Woking, Chobhara; Sandpit Shalford, E. $\mathcal{1}$. Butler; Bournemonth, Dale.

N. thymi, Niolfj (maculatus, D. \& S.).-Very like the preceding, but shorter and broader; the pronotum more transverse and less widened posteriorly, with only an indication of a central keel, close to the anterior margin, and a dark band across the anterior impression; elytra whitish ochreous, shining, with the apical margin blackish brown, sides more rounded than in lineatus, membrane somewhat dusky; underside of head and thorax largely black; abdomen ochreous with black markings; legs 
ochreous, femora spotted with black; in var. maculatus almost entirely black, and in this variety the whole insect is darker than the type.

L. $4 \mathrm{~mm}$.

Common and grenerally distributed; Bundoran, Donegal, Rev.W. F. Johnson; Pertisshire and Morayshire, Norman; Scilly Isles, Mason; Isle of Man, Blutch.

\section{CYMINA.}

(2) 1. Species subelongate, antenniferous tubercles prominent . . . . Cruss.

(1) 2. Species subrotundate, antenniferous tubercles small, invisible from above

IschNorHTanus.

\section{CYMUS, Hahn。}

There are only four European species of this genus, three of which are found in this country. They are subelougate in form, with the sides of the elytramore or less rounded; the eyes do not quite touch the pronotum, the antenniferous tubercules are well defined and angular, the cheeks are much shorter than the central lobe; the pronotum is trapezoidal, the scutellum short, the apical margin of the corium long, legs short, simple. All the species are ochreous in colour, glabrous and punctured; they are found by sweeping in damp places, and are all closely allied.

(2) 1. Scutellum with a strongly raised central carina, dorsal carina of pronotum elongate extending for nearly two thirds of its length GLANDICOLOR.

(1) 2. Scutellum without a keel or with only a
slight one, dorsal carina of pronotum short, not nearly extending to two thirds of its length.

(4) 3. Puncturation of elytra similar and irre-

(3) to Two more or less distinct parallel lines
of punctures along the claval suture, the rest of the corium irregularly punctured cuavicusus.

C. glandicolor, IIahn.-Ochreous, glubrous, strongly punctured. Head with a slight ferruginous tint, nearly as loug as its width between the eyes, second and third joints of the antenna subequal, fourth elongate, ovate, black; 
pronotum trapezoidal, anterior margin straight, about lialt the length of the base, sides very slightly rounded, base nearly straight, disc raised posterionly, with a long well-defined dorsal carina; scutellum with a smooth pale strongly raised central carina; elytra with the sides gradually rounded, the apical margin of the corium very long, sometimes narrowly brown; there is also a longitudinal dark central line near the apex of the corium; membrane narrower" than in the other species; legs short, apical joint of tho tarsi black.

L. $4 \mathrm{~mm}$.

Genorally distributed in the Sonth of Eugland; Cardiff, Dillups: Freshwater Bay, Pembrokeshire, Murshall.

There is a curious variety of this species which has the pronotum more convex, much wider and more rised posteriorly, and the elytra shorter and wider, the sides more rounded and the apical margin of the corium shorter. Another variety, somewhat intermediate between this and the typical form, but smaller than either, has been taken by Mr. E. A. Butler, on Solunum dulcumara.

C. melanocephalus, Fieb-Smaller and darker than the preceding, the head, thorax and scutellum being dark brown, and the head in some specimens nearly black; the head is distinctly shorter, and the antenniferous tubercles blunter; the scutellum has no keel, and the keel of the pronotum is shorter; the elytra are ochreous, irregularly and largely punctured throughout, with tho apical margin of the corium brown; membrane hyaline; abdomen brown; legs reddish ochreous, apical joint of the tarsi black.

L. $3 \frac{1}{2} \mathrm{~mm}$.

Chobham and Woking, not rarely; Esher, Caterham, Champion; Norfolk, Elwards.

C. claviculus, $H^{\top} a l l$. - Smaller than melanoccpholus and much paler in colour; the head shorter and broader, the second joint of the antenno rather shorter than the third; the pronotum wider posteriorly in proportion to its length; 
the scutelium with a pale central line, sometimes more or less cariniform; elytra rather more shining, with two regular almost parallel lines of punctures on the corium near the claval suture, apical margin of the corium shorter, narrowly brown; abdomen and legs ochreous, apical joint of the tarsi black.

L. $3 \mathrm{~mm}$.

Generally distributed in South of England; 'I'aff's Well, S. Wales; Ireland, Haliday.

A variety of this species has been taken by M[r. E. A. Butler near Chilworth, Surrey, which is decidedly darker than the typical form and more resembles melanocephulus; in shape, however, it is exactly like the pale form, so that there can be little doubt of their identity.

\section{ISCHNORHYNCHUS, Ficl.}

Species wide and ovate; head with the eyes touching the pronotum, antenniferous tubercles small, inferior, cheeks very uarrow, but as long or nearly as long as the central lobe; pronotum trapezoidal, very much widened behiud, the base rounded; the scutellum large, simple; elytra with the sides more or less rounded; legs simple. There are only two known European species of this genus, which are scarcely distinguishable except by size and habitat.

(2) 1. Larger, reddish brown, occurs on trees . . RESEDE.

(1) 2. Smaller, ochreous brown, occurs on heath . . GEMLNATUS.

I. resedæ, Panz. (didymus, Lett.).-Red brown, or brownish ochreous, second and third joints of the antennx ochreons, the apex of the second black, third joint shorter than the second, and about equal in length to the fourth, which with the basal joint is black; pronotum punctured, with a black anterior transverse impression; scutellum punctured, but more remotely than the pronotum; clavus with three parallel rows of punctures; corium puuctured ouly between the discal nerves, and with a row of punctures 
along its margins, two small punctiform spots on the disc, and one at the apex of one or both discal nerves and the extreme apex of the corium black; abdomen black, reddish towards the apex; legs brown, apical joints of the tarsi black.

L. $5 \mathrm{~mm}$.

Off varions trees by beating; Coombe Wood, Deal; Hastings, E. A. Butler; Oxshott, Chobham, Cardiff, Billups; Mickleham, Hampstead, Darenth, Champion; Morayshire, Norman. On birch, Norfolk, E'twerds"; Torquay, Parfitt; Haldon, Prince 'Town, Dartmoor, Bignell. On alders, Glanvilles Wootton, Bonchurch, Dale.

I. geminatus, Fiel. (resedx, D. \&. S.).-Smaller and paler than the preceding, the eyes slightly larger and more prominent, the puncturation of the pronotum larger and more distinct; elytra rather longer and the membrane more fully developed; otherwise apparently similar.

L. $3.3 \mathrm{~mm}$.

Common by sweeping heath, and generally distributed.

\section{BLISSINA.}

\section{ISCHNODEMUS, Fiel.}

A genus of long flat parallel-sided species, of which we Lave ouly one in this country, out of the six species recorded in Dr. Puton's catalogue. 'The head is much constricted behind the eyes, the central lobe of the face is much longer than the cheeks, and rounded in front; antenniferous tubercles distinct, antenne with the first joint short and stout; pronotum flat, and subquadrate, its sides rounded in front, base sinuate; scutellum wider than long; elytra rarely developed, but when developed with the apical margin of the corium very long and nearly straight; in the undeveloped form the elytra are about twice aud a half as long as the scutellum, with their apices rounded, grenital segments scarcely visible from above; legs short, simple. 
I. sabuleti, Fall.-Elongate, flat, parallel-sided, black. Head and pronotum clothed with a close greyish pubescence; antenne black, with the second and fourth joints subequal in length, the third shorter; pronotum slightly narrower in front than behind, its anterior angles largely rounded, its base sinuate, disc flat, basal margin, at least near the posterior angles, pale; scutellum black; elytra pale ochreous, with a dark line running parallel to the margins of the corium in the undeveloped form, the space between it and the apical margin of the corium in the developed form entirely brown, membrane in the developed form slightly dusky with brown nervures; abdomen clothed with fine grey pubescence, edges of the connexivum ochreous; legs with the apices of the femora, the tibia and tarsi testaceous, apical joint of these last black.

L. $4-4 \frac{1}{2} \mathrm{~mm}$.

Folkestone; Merton, Power; in August and September.

\section{HENESTARINA.}

\section{HENESTARIS, Spin。}

Easily known from all our other genera of the Lygaidce by the pedunculate eyes. The head is short, the cheeks nearly as long as the central lobe, antenniferons tubercles small, inferior, vertex produced laterally into a process on each side, which bears the eye at its apex; pronotum more or less trapezoidal; abdomen in the $\delta$ with the genital segments visible from above; legs simple. There are only two European species, both of which occur in this country.

(2) 1. Eyes on very long pedicels, reaching far be-

(1) yond the anterior margin of the pronotum. LATICEPS.

(1) 2. Eyes on shorter pedicels, reaching only sligutly beyond the pronotum and nearly embracing its anterior angles. IIALOPHILUS,

H. laticeps, Curt.-Ochreous, with darker markings 
and finely pubescent. Head more or less mottled with black, the eyes produced on very long narrow pedicels, which are slightly inclined upwards and forwards; the distance between the eye and the pronotum is considerably longer than the eye itself; antenne with the basal joint mottled with black, apical joint dark brown or black, rather shorter than the third in length: pronotum considerably widened and raised belind, its sides nearly straight, disc punctured with black with a pale central line, which has a small impression on each side of it in front of the middle, closely punctured with black; scutellum with a pale central licel posteriorly and a small pale elevation at the base on each side; elytra punctured with black, and generally with a small ocellate spot near the base of the posterior margin; membrane opaque, white, unspotted at the basal angle, but granulated and streaked with black on the dise; abdomen above black in the $q$; $\operatorname{leg} s$ testaceous spotted with black.

L. $5-5 \frac{1}{2} \mathrm{~mm}$.

'Teignmouth, Dawlish, Hastingss; Bexhill, Butler; Deal, Billups: Budleigh Salterton, Portland, Lulworth, Seaton, Charmouth, Dale; Clacton-on-Sea, Blatch; S. Devou and Cornwall coasts and Milford Haven, Marshull.

H. halophilus, Burm.-Easily distinguished by the shape of the head, the eyes being less produced, and on wider pedicels, which are not inclined upwards, but slightly backwards ; the distance between the eye and the pronotum is not nearly as long as the eye, and the eyes somewhat embrace the anterior margin of the pronotum; the antennie have their apical joints longor than the third; pronotum much shorter and squarer than in laticeps and less raised posterjorly. In colour the whole insect is generilly darker, sometimes nearly black, but I have some as pale as laticeps, which also varies a good deal in this respect.

L. $55 \mathrm{~mm}$.

Herne Bay, in a salt marsh near Hampton; Whitstable 
and Sheppey, Champion; Whitsand Bay, near Plymouth, .T. .T. Walker.

\section{ARTHENEINA.}

\section{CHILACIS, Fich.}

'I'his is the only genus we have of this small subfamily, and it may be easily known by its ventral stigmata and the long cheeks, as well as by the sharp foliaceous sides of the pronotum. In form it is almost regularly elliptic, the cheeks are almost as long as the central lobe of the face, the antenna are short, with the basal joint stout and short, and the second about trice as long as the third, the antenniferous tubercles are small and inferior, the eyes not prominent, rostrum reaching to the intermediate coxa; pronotum subtrapezoidal, lateral margins foliaceous; scutellum impressed, abdominal stigmata ventral, legs simple. There is only one European species.

C. typhæ, Perris.-Flat, ochreons, glabrous, shining, strongly punctured. Head across the eyes, not so wide as the anterior margin of the pronotum; antenne brown; there are two impressed dark streaks down the face; vertex smooth, with a few large irregular punctures; ocelli very strongly developed; anterior margin of the pronotum emarginate, sides somewhat sinuate, base very slightly and very widely emarginate, disc largely and irregularly punctured with black, impressed along the sides; scutellum with a central dark impression, which is deeply punctured; elytra flat, punctured with black, the nerves much raised and pale, membrane whitish with a darker central cloud; abdomen reddish ochreous, black at the base above and beneath; connexivum with small darker spots; head and thorax beneath black, the latter margined with white and with a white spot ncar each coxa ; legs testaceous, apical joint of the tarsi black.

L. $4-5 \mathrm{~mm}$. 
In bulrush heads, Stockton, Rudd; Ashburnam, Sussex, Butler; Norfolk, Lilwards; Hastings, Deal.

\section{HETEROGASTRINA.}

\section{HETEROGASTER, Schill.}

A genus resembling many of those belonging to the Pachymerina, but distinguishable by the neuration of the membrane, its nervures originating from basal cells. Head short, face triangular, antenuilerous tubercles angular at the sides, cheeks as long as the central lobe, basal joint of the anteuna scarcely thicker than the rest, rostrum reaching to about the middle of the mesosternum; pronotum trapezoidal ; scutellum large, as long or longer than wide, membrane with two distinet basal cells; legs with the front femora thickened, and bearing a spine-like tooth beyond the middle. We have two of the five Europenn species in Britain.

(2) 1. Head and pronotum clotled with long erect hairs; tibia with three black bands. URTIC.

(1) 2. Head and pronotum not clothed with erect hairs; tibia with only the base and apex black

ARTEMISI.‡.

H. urticx, Fab-Brouzy, variegated with paler markings, clothed with erect hairs. Head brouzy black, punctured, central lobe of the fice with a pale spot; antenna with the basal joint bronzy black, its apex and the other joints pale; pronotum bronzy, lateral margins sinuate, pale, posterior angles lobately rounded, base sinuate, disc punctured and clothed with pale erect hairs, with a large pale spot on each side of the base; scutellum bronzy, foveated, its extreme apex pale; elytra ochreous, with bronzy spots, membrane subhyaline with a small black spot near the base, and a few sliglit darker clonds; abdomen blue-black above and beneath; connexivum with pale spots, and the $q$ with a pale central spot beneath; 
femora pale at the base and apex; tibix with three black rings, tarsi with the apex of the first and last joints black.

L. $6 \mathrm{nrm}$.

On nettles, Deal; Betchworth, Surrey, Porer; Darenth, Hammersmith, Champion; Portland, Lulworth, Seaton, Dale; Scilly Isles, Mason; Lynn, Norfolk, Edwards; Wicken Fen, Portland, Blatch; Slapton Ley, Devon; Common on nettles, Weymouth, Markfull; Brighthampton, Oxon, Stone; under Frodium, Deal, C. G. Irall; Ireland, Huliday; "abundant in September, 1886, in a hollow stem of Furze, at Hayling Island," also Cardiff, Billups.

H. artemisiæ, Schill.-Smaller than urtice. Head bronzy, clothed with short adpressed silvery hairs, punctured; antenne with the basal joint bronzy, its apex pale, second palo except at the extreme base, third and fourth dark, third with a pale band just above the base; pronotum punctured and pubescent like the head, bronzy, its base widely ochreous, longer and narrower than in urticx, the sides and base slightly sinuate; scutellum bronzy, apex with a pale raised central line; elytra punctured and pubescent, like the head and prouotum, ochreous, with a dark spot at the inner apical angle, which varies much in size, membrane milky white, with slightly darker clouds; abdomen bronzy, connexivum with pale spots; femora pale at the apex, tibio with the base black, and with a dark apical spot, tarsi with the apex of the first and last joints dirrk.

L. $4 \frac{1}{2}-5 \mathrm{~mm}$.

In moss, Reigate; Mickleham, Caterham, Champion; Hayling Island, Billups.

\section{PACHYMERINA.}

(2) 1. Pronotum constricter behind the middle, sides obtuse, not carinated, rounded in front of and

P'Lociomerus 
(1) 2. Pronotnm not constricted behind the midllle, or if constricted then with its siles carinated.

(10) :. Pronotum with its sirles evenly foliaceous throughout, and regularly rounderl.

(ii) 4 Antennne not bristly.

(-) 5. Eyes not projecting beyond the angles of the pronotum.

(i) i. Basal joiut of posteriol tarsi twice as long as the other two together.

(4i) 7. Basal joint of prosterior tarsi not

twice as long as the others
(i) $\therefore$ Eyes projecting beyond the anterior

Apitantes. angles of the pronotum . .

(a) 11!. Antewno bristly its sides not evenly Trapezonotus.

\section{Beostos.}

EMiblethis. foliaceous throughout.

('i) 11. Pronotum with a small pale foliaceous spot at the sides just behiud the middle.

(13) 12. Species very Hat and broad

Gastrones.

(12) 13. Species not very Hat and broal.

(19) 14. Basal joint of the antennx not uearly so long as the second.

(16) 15. Basal joint of the antennx projecting beyond the apex of the head for more than half its length.

(15) 16. Basal joint of the antenne not pro-

ERfuocoris, jecting beyond the apex of the head for balf its length.

(1i) 17. Eyes not tonching the pronotum

(Ii) 1.2. Eyes touching the pronotum

(11) 1:1. Basal joint of the antenne threequarters the length of the second

(11) 21). Pronotum without a pale lateral foliaceous spot.

(2) 21. Species clothel with erect hairs .

(21) 2.:. Species not clothed with erect hairs.

(32) $2:$ Anterior femora simple.

(ㄷ) 4 . Species linear and parallel-sided.

(21i) … Eyes small, hardly a quarter the width of the vertes quale

(․) 20i. Eyes large, nearly as wite as half

the vertex
(21) 25 . Species not linear and parallel-sideit. with the puncturation large and remote . .

(2) 2). Pronotum not very shining, puncturation close.

(i) in. Surface puluescent

Scolorostethus. Peritrecius.

Notrk hill .

Pionosonus.

MACRODEMA.

Is HATUURL.

Lasiosorgus.

S'TtGNis. 
(30) 31. Surface not pubescent

Acojipus.

(23) 32. Anterior femora with one or more spines.

(i1) 33. Head small, much narrower than the

(33) 34. Head as wide or wider than the anterior margin of the pro. notum.

(36) 35. Anterior femora with one or two fine spine-like teetli . . .

(35) 36. Anterior femora with a strong tooth and several finer ones, or ouly with sereral small teeth.

(38) 37. Anterior femora with a strong tooth and smaller ones.

(37) 38. Anterior femora with a row of small Plixtmistes.

Drraros.

Ruxparochroyes. teeth near the apex . . Tropistetuos.

\section{PLOCIOMERUS, Suy.}

Easily known from any of our other genera by the ecarinate sides and constricted waist of the pronotum. Head with the eyes not touching the pronotum, ocelli very distinct, antenuiferous tubercles strongly defined; anteun with the basal joint reaching beyond the apex of the face for about a third of its length, cheeks much shorter than the central lobe, rostrum not quite reaching to the intermediate coxæ; pronotum with the sides more or less rounded in front, then deeply sinuate, and again slightly rounded to the posterior angles, the constriction of the sides continued across the disc; scutellum simple; elytra subparallel-sided; membrane developed; legs with the anterior femora incrassate, with strong spines. 'There are six recorded European species, of which we have two in our list. There is a third species, Luchsii, found in Sweden, which we may yet hope to add to our fauna; it is a mountain species.

(2) 1. Pronotum with the siles only slightly rounded in front of its waist, without tine

(1) 2. Pronotum with the sides much rounded in
front of the waist, clothed with fine erect pubescence. . . . Iminus. 
P. fracticollis, Smill.-Head and antenne black, the second and third joints of the latter slightly paler except at the apex; face clothed with a fine adpressed golden pubescence; pronotum punctured, black in front, base with ill-defined ochreous spots, sides constricted behiud the middle, disc with a deep transverse impression, the contimuation of the lateral constriction; surface almost glabrous, but with a short scattered golden pubescence visible through a strong power; scutellum black, impressed at the base, the apex ochreous and the sides with a small reddish spot on each; elytra with the clavus and corium ochreous, punctured with black, and with dark lines bordering some of the nerves; abdomen black, legs ochreous red, with a more or less dark apical band on the femora, anterior femorn with two large strong teeth, each with one or more smaller ones on its distal side, anterior tibia straight in both sexes.

L. $5 \mathrm{~mm}$.

Sweeping herbage, ditch sides, Horning Fen, Edwards; Wicken aud Ranworth, Champion; New Forest, Fouler; Whittlesea Mere, Dale.

P. luridus, Mahn.-Much darker in colour than the preceding, finely pilose with upright hairs. Head black, antenna brownish, pilose, apical joint longer than the second; pronotum reddish brown, velvety, of a rather brighter red on each side of the disc, sides very much rounded in front, making the waist very much moro distinct than in fiucticollis, it is also placed rather nearer the posterior angles; scutellum black; elytra with the clavus and corium ochreons, much suffused with brown towards the apex; abdomen brown, rather lighter towards the sides; legs testaceous brown, anterior femora with three long spines and several smaller ones, anterior tibia curved in the $\delta$.

L. $4.1-5 \mathrm{~mm}$.

In Sphagnum, Chobham; New Forest. 


$$
\text { Lysida. }
$$

\section{RHYPAROCHROMUS, Cut.}

Eyes nearly or quite touching the anterior margin of the pronotum, antenniferous tubercles distinct, antennx witls the fourth joint as long or longer than the second, rostrum reaching to about the intermediato coxa, ocelli small; pronotum subruadrate, very little narrowed in front, sides sinuate behind the middle, narrowly and distinctly raised and carinated; scutellum large; elytra with the sides subparallel, its membrane generally developed, but somerhat shortened in antennatus; legs with the anterior femora strongly incrassated and with a strong spine or group of spines towards the apex. This is a genus containing a good many species, of which we have only four in this country. Most, if not all, of the other Europenn species are from the soutl, and not likely to occur with us.

(4) 1. Surface of pronotum dull.

(3) 2. Tibiro and antennæo black, pronotum without long hairs. . . Dilatatus.

(2) 3. Tibie and second joint of antenua generally paler, pronotum with long hairs - CuIRAGR.

(1) 4. Surface of pronotum shining.

(6) 5. Legs entirely yellow . . ANTENNATCS,

(5) 6. Femora of anterior legs black : : IR.ETEXTatus.

R. dilatatus, H. Scluf.-Not shining, entirely black, except the nerves of the ely tra, which are generally brownish, and sometimes the apex of the femora, which may have a slight rufescent tinge. Head largely punctured, clothed with fine adpressed golden pubescence, antenniferous tubercles angularly produced at the sides, cheeks inuch shorter than the central lobe, their apices somewhat truncately rounded, antennæ finely pilose; pronotum subtrapeziform, anterior margin emarginate, sides slightly rounded in front then sinuate behind the middle, margins rellexed, base largely emarginate, surface punctured with large punctures, disc with a deep transverse impression Gi? 
behind the mithle; sentellum punctured, raised at the base with a cuntral carina at the apex; elytra with the corium and clavus pmetured, a line along the claval suture, and ocensiomally the nerves, paler, membrano developed, with a pale spot at the base; abdumen bronzy black, legs black, clothed with short hairs and longer black bristles, anterior femora strongly incrassated, with a strong spine near the apex and with several smaller oues on its distal side, anterior tibia curved, very fiuely crenulate at the base beneath.

L. $5 \mathrm{~mm}$.

In mosi, etc.

Weybridge, Woking, Chobham; Esher, IMrrshull; Norfolk, Elurude; Hastings, Ewhurst, Leith Hill, Lutler; Reigate, J. Iinnell; Stoneham, Hants, Addington Hills, 7)ouglus and Sentt; Weghridue, Deal, Billups: Knighton Heatl, Parley Hoath, Land's Find, Duele.

R. chiragra, Fub. (var. sabulirolu, Thom..).-Rather. smaller and distinctly marrower thim dilatatus, the second juint of the antenne, the corimm and clavus and the tibia more or less ferruginous, except in the var. nifricomis, 1). \& S., which has the antenna entirely black. Head with the antenniferous tubercles and cheeks less prominent than in the preceding species, its surface with longer hairs; pronotum longer and less widened posteriorly, its disc clothed with loug upright hairs; corinm ochreous or ferruginons, more or less clouded and spotted with black, nembrane paler than in ditatutus, its base and sometimes a spot near the apex pale; legs with the base of the femora, the tibive of the antcrior pairs except at the apex, and the basal joint of the tarsi ferrugiuous; tibix, especially the intermediate pair, with strong black bristles and fine lairs, anterior femora incrassated, with a strong pale spine followed on the distal side hy several smaller ones, auterior tibic curved.

L. $4.1 \mathrm{~mm}$. 


$$
\text { i.jgardi. }
$$

Generally distributed, in moss, rubbish, dend leares, roots of grass, etc.

A variety of this species occurs with all the tilice entirely pale ochreous, the third joint of tho antenneo as well as the second more or less pale, aud the pronotum less strongly punctured at the base. This has been described by Thomson as sabulicolu; it oceurs on sandy coasts. I artmitted this as a species in my Symopsis, but feel that the characters are not strong enough to maintain it as such.

R. antennatus, Schill. - Head and thorax black and shining, elytra with the membrane undeveloped, the corium more or less pale at the base, legs entirely pale.

Head largely punctured, with a few scattered long hairs, antenniferous tubercles very slightly prominent, antenna finely pilose, with the basal joint black at the base, jellow at the apex, second entirely yellow, third and fourth black; pronotum as loug as wide, with the auterior margin emarginate, lateral margins narrowly rettexed, rounded and converging slightly behind the middle, then produced again to the posterior angles, base sinuate; dise polisbed and shining, with only a ferv scattered punctures, anteriorly and posteriorly more closely punctured; scutellum dull, finely punctured at the base, coarsely at the sides and apex; elytra with the corium and clavus pilose, clavus deeply punctured in rows, corium with a row of punctures along the claval suture, its disc less deeply and somervat remotely punctured, inembrane ablireviated, dark, paler at the base; abdomen black, shining, with an adpressed golden pubescence beneath; legs entirely pale testaceous, smooth, shining, with a few bristles on the internal margins of the tibix; frout femora with a large spine and several smaller ones near the apex.

L. $\frac{1}{2}-1 \frac{\mathrm{l}}{\mathrm{m} m}$.

Reigate Hill in moss, Herne Bay; Ewhurst at roots, 
Butler; Manaton, Devon, l'arfitt; Sheerness, Caterham, Whitstable, Chatham, Siudown, Chompion.

R. prætextatus,-Bright and shining, glabrons. Head and pronotum black, largely punctured, antenure black, with the apex of the first and of the second joints pale; scutellum black, finely punctured at the base, coarsely elsewhere; elytra with the clavus and corium punctured, pale ochreous, the apes of the latter widely black, membrane dark with a pale basal spot; abdomen black, legs pale testaceous, the anterior femora black except at the extreme apex.

L. $4 \frac{1}{2} \mathrm{~mm}$.

Local, but not rare where it occurs, at roots of grass, in moss, ctc., Deal; Camber Sand Hills, Butler; Mousehold Ieath, Norfolk, Edwerde; Hunstanton, Weymouth, Blutch; Braunton Burrows, Devon, Marshall; St. Ives, Cornwall, $J$. E. Iteson; Southend, Walton, Champion; Portlaud, Dale.

\section{TROPISTETHUS, Fieb.}

A genus with only one European representative, which is a very suall species, in fact, the smallest of our Lyqueicle. It may be known by the almost ecarinate pronutal margins, and by having two longer spines on the anterior femora, followed by uumerous small ones between them and the apex of the femora. Head with the antenniferous tubercles largely developed, blunt, eyes not touching the anterior margin of the pronotum, rostrum reaching to the intermediate coxio; pronotum subtrapeziform, anterior margin and base rather deeply sinuate, sides slightly so behind the middle, with a very obtuse carina ouly visible when examined laterally; scutellum raised at the base; elytra with the membrane often not reaching to the apex of the abdomen; anterior femora incrassated, bearing beneath two rather longer fine spines and numerous shorter ones; tibia without bristles. 
T. holosericeus, Schlt:-Head and pronotum black or brownish black, the latter clothed with fine velvety pubescence, head rugosely punctured, antenne finely pubescent, of the same colour as tho head; pronotum slightly widest behind, largely punctured behind the probasal depression, finely so in front of it ; scutellum black, rather closely punctured at the base, remotely so towards the apex; elytra with the corium and clavus deeply punctured, ochreous, clouded with brown towards the apex, especially at the iuner apical angle, membrane whitish, often shortened so as to expose the apex of the abdomen; abdomen black, finely pubescent, legs ochroous, tibia and tarsi paler.

L. $2 \mathrm{~mm}$.

Rare. In moss, etc., Dr. P'uton says, often in ants' nests, but I am not aware of its having been found with ants in Britain; Reigate, Wandsworth; Seaton Devon, $D r$. Tower; Mickleham, Champion; Ventnor, Duuglas and Scott. Common at roots of grass, Headley Lane and Reigate, Billups.

\section{ISCHNOCORIS, Fieb.}

Subelongate, head short, eyes large, almost touching the anterior margin of the pronotum, the distance between them hardly so wide as twice the width of the eye, antenniferous tubercles small, ocelli distinct, rostrum reaching to just beyond the intermediate coxie; pronotum slightly widened posteriorly, more so in the developed form; elytra with the membrane generally shortened and the wings undeveloped, but in the developed form the membrane reaches to beyond the apex of the abdomen; apical margins of the abdominal segments above simple; anterior femora not toothed or spinose. There are three European species of this genus, all closely allied.

I. angustulus, Buh. (hemipterus, D.\& S., Sumcl.etc.).Head and thorax black, base of the latter and the apices of tho first and second antenval joints pale, clavus and corium 
ochreous, punctured with black, legs ferruginous, femora with a black apical band. Head very finely and rugosely punctured, apical joint of the antenna shorter than the second; pronotum widened slightly posteriorly, especially in the developed form, its sides straight, narrowly carimated, base nearly straight, disc tlat, black and finely punctured in front, the ochreous basal portion with very large black puuctures; scutellam punctured, its extreme apex pale; elytra with the corium and clavus punctured with black in rows aloug the nerves, external apical angle of the former black; abdomen black, beneath with a spot near each coxi, and the posterior margin of the metathorix pale, legrs simple.

L. $21 \mathrm{x}$ m.

Common under heath and genemily distributed over the South of England, etc. Macropterous form rare; I once took several in heaps of dead herbage, etc., at Woking in May. Aviemore, Champion.

MACRODEMA, Ficb.

Very like the preceding genus in general form and habitat, but more elongate, the eyes much smaller in proportion to the width of the vertex, and not touching the pronotum, the vertex being five times as wide as ench eye; pronotum longer and more parallel-sided in the brachypterous form; abdomen more elongate, the posterior margins of the third and fourth dorsal segments widely produced, and truncate posteriorly. There is only one European exponent of this genus. It is ncarly always found micropterous, but the macropterous form occurs occasionally.

M. micropterum, Curt.-Black, clarus and corium and a spot on each side of the base of the pronotum, and the apex of the scutellum, pale, membrane in the developed form dark with three basal spots white. Head and pronotum shiming, with a somewhat bromzy tinge, largely and 
deeply punctured; the latter dull across the base, sides nearly parallel and straight in the brachypterous form, diverging posteriorly in the macropterons, base deeply sinuate, disc with a narrowly impressed dorsal line; scutellum punctured; elytra with the clavas and corium punctured with black in lines, in the brachypterous form with scarcely any membrane, that of the macropterous reaching to the apex of the abdomen; abdomen and legs black, femora paler at the base, coxao and a spot near each pale.

L. $2 \frac{1}{3}-3 \mathrm{~mm}$.

Common on heaths, under Erica, etc., and generally distributed but not recorded from Ireland. I have never taken the macropterons form myself, but Mr. E. A. Butler has met with it not infrequently.

\section{PIONOSOMUS, Ficb.}

Suboval, clothed with erect hairs. Head with the eyes moderate sized, touching the pronotum, antenniferous tubercles small, ocelli distinct; pronotum transverse, slightly widened posteriorly, lateral margins narrowly carinated, base slightly sinuate; scutellum large, lateral margins of the corium slightly rounded, membrane not quite reaching the apex of the abdomen; legs short, tibio spinose, anterior femora incrassated, simple. A very distinct little genus, of which there are three Luropean exponents, all resembling each other very closely.

P. varius, Wolti--Bronzy black, the second joint of the antenne except at the apex, a spot on each side of the base of the pronotum; the extreme apex of the scutellum, the clavus and corium except a spot near the base, the apex and a lateral band in the contre of the latter, ochreous; membrane blackish with three pale basal spots, legs with the tibire and tarsi ochreous. Head closely and rugosely punctured, clothed with erect bristly hairs, antenne pilose; pronotum with the sides slightly sinuate posteriorly, disc clothed with bristly hairs, remotely punc- 
tured near its centre, more closely in front, and with vory large punctures near the base; scutellum dull, punctured and with short bristles; elytra with the corium and clavus clothed with short bristly upright hairs, punctured with black in lines; abdomen beneath pilose; legs with erect bristles, anterior femora incrassated, simple.

L. $2 \mathrm{~mm}$.

Very rare. Sandwich on the sandhills; the only recent capture of this species was made by Mr. A. Piffard, in June, 1890. The Rev. T. A. Marshall writes to me that he found it at Sranage, but did not capture any.

\section{PLINTHISUS, Fieb.}

Flat, glabrous, shining. Head much narrower than the pronotum, antenniferous tubercles very small, ocelli distinct, eyes touching or nearly touching the pronotum, the anterior angles of which slightly embrace them; pronotum with the anterior margin deeply emarginate, sides rounded near the anterior angles then nearly straight, margins finely carinated, base slightly sinuate, disc nearly flat; elytra in the developed form with the membrane nearly reaching to the apex of the abdomen, in the undereloped form shortened, exposing one or more abdominal segments; legs with the anterior femora incrassated, with two small sharp spines beneath.

There are over twenty species of this genus in the Palaarctic fauna, but we have only one as yet in this country. I'. pusillus, however, is quite likely to occur here; the others have mostly a southern distribution.

P. brevipennis, Lats. (wacr. liclentulus, H. Schff.). Pitchy black, or more or less brown, shining, glabrous. Head finely and very shallowly punctured, antenno piceous; pronotum slightly widened posteriorly (macr.), or subquadrate (brach.), deeply punctured posteriorly, superficially so on the disc; scutellum punctured; elytra 
with the clavus punctured in lines, the corium with a row of punctures along the claval suture, the rest irregularly punctured; membrane slightly smoky; in the brachipterous form two dorsal segments are exposed; abdomen black, connexivum slightly paler; legs piceous, with a few fine, short, erect, bristly hairs.

L. $2-2 \frac{1}{4} \mathrm{~mm}$.

Common in many sandy localities, but macropterous form rare, Weybridge, Woking, Chobham; Norfolk, Edwards; St. Ives and Scilly Isles, J. E. Muson; Polperro, Cornwall, and Bridgenorth, Devon, MLurstuall; Reigate, Weymouth, Blatch; Camber, Shalford, Ewhurst, Lowestoft, Butler; Sheerness, Sheppey, Chatham, Wimbledon, Salisbury, Champion; Dartford, Southend, Ventnor, Douglas and Scott; Deal, Dagenham Essex, Cowbridge South Wales, Billups; Lulworth, Dale.

\section{LASIOSOMUS, Ficb.}

Shining, clothed with rather long fine hairs. Head with the eyes not touching the pronotum, antenniferous tubercles well developed; antennæ with the basal joint reaching beyond the apex of the head by about half its length; pronotum trapeziform, its anterior margin slightly raised, about the width of the head behind the eyes, with a row of large punctures within it, sides rounded in front; elytra with the sides slightly rounded; membrane pale with a yellowish tinge, nerves concolorous; legs simple, anterior femora hardly incrassated.

L. enervis, H. Schifj--Head black, shining, irregularly punctured, central lobe of the face yellow; antenne with the first three joints clear testaceous, finely pilose, apical joint black; pronotum shining, finely pilose, considerably widened behind, black; anterior and lateral margins, and a band across the base testaceous, surfaco with very large deep punctures except on the black part of the disc, where 
the punctures are finer and more scatterel; scutellum raised at the base, puuctured, black, its apex paler; elytra finely pilose, with the clavus punctured in lines, the corium bright, shining, with two rows of punctures along the claval suture, and some large punctures towards the lateral margin ; a longitudinal space between these is quite smooth and impunctate; membrane shining, hyaline, with a yellowish tinge; abdomen pitchy black; legrs clear testaceous.

L. $3 \frac{1}{3} \mathrm{~mm}$.

Very rare, "Darlaud Hill, on chalk," near Chatham, Champion; Weybridge, Billups.

This insect bears a superficial resemblance to Stygnus pedestris, but its shining surface and pale whitish membrane would, I think, help anyoue to know it at first sight.

\section{ACOMPUS, Fieb.}

Somewhat allied to the preceding genus but with much more promiuent eyes, shoxter basal joints of the antemn, which hardly extend beyond the apex of the head for more than a quarter of their leugth, surface deeply punctured, without erect pubescence. Species dimorphic; in the developed form with the membrane as long as the apex of the abdomen, in the undeveloped with the membrane very short; legs simple, anterior femora unirmed. 'l'here is only one European species of this genus.

A. rufipes, Wolfj-Black, second and third antennal joints and legs testaceous, corium and clavus ochreous, the apex of the former and a spot at its inner apical augle brownish black. Head short, wide, deeply punctured; antennx with the apex of the basal joint and the whole of the sccond and third testaceous; pronotum dull, very closely and largely punctured, trapeziform, sides nearly straight, carine narrow, base sinuate; scutellum dull black, deeply and closely puncturer, its extreme apex pale; elytra with the corium and clavus deeply punctured, rather shining", membrame milky white, a slightly darker cloud down tho 
middle of each side; the abdomen very closely punctured, clothed with very short whitish lairs; legs testaceous, anterior femora sometimes with a dark central band.

L. $4 \mathrm{~mm}$.

In damp places, Suodland and Chatliam, Kent, Nerr Forest, Wicken Fen, Horning, Chumpion; Redhill, Surrey, J. Irinnell; Marshes, Norfolk, Edwards; Piddletown, Dorset, Blatch; Weybridge and Oxshott, Billups; Glanvilles Wootton, Dorset, Land's End, Dule.

\section{STYGNUS, Fieb.}

Closely allied to Acompus, but easily recoguizable by the more finely punctured and the finely pubescent upper surface, and by the dull surface of the elytra, whose clavis has four series of punctures instead of only three as in Acompus; anterior femora beneath with a series of fine Lairs, or spine-like bristles. One species, viz. musticus, is dimorphous, the undeveloped form being the common one; the developed form is the Stethotropis incana, Fieb. We possess three out of the five recorded European species; pyymans, Saluberg, which is closely allied to arenarius, but has a longer terminal joint to the antenno, and is smaller in size, may yet be added to our list.

(2) 1. Pronotum black or brown, not paler posteriorly RUsTICUs.

(1) 2. Pronotum paler at the base.

(4) 3. Legs clear testaceous throughout . . . PLDEsTris.

(3) 4. Legs with the femora brown . . AREXARICs.

S. rusticus, Fall. (incanus, Fieb. (macr.).-Black or brown, clothed with short adpressed pale hairs, dull, closely punctured, legs and antennæ ferruginous, except the apical joint of the latter, which is black or brown. Head short, triangular; eyes prominent, projecting beyond the pronotum at its anterior angles; pronotum trapeziform, sides rounded in front and slightly sinnate behind the middle; base rather deeply sinuate; scutellum punctured like the pronotum; elytra with the corium and clavus rather more 
finely punctured, and paler in some examples than the pronotum; membrane generally abbreviated, but in the developed form obscurely smoky, with paler nervures; legs with the anterior femora boneath bearing a row of fine bristle-like spines.

L. $3 \frac{1}{2}-1 \mathrm{~mm}$.

By sweeping, Reigate, Choblam; Hastings, E. P. Collett; Bexhill, Battle, Hurst Green, Ewhurst, Barnet, macropterous form frequent, Butler; Norfolk, Edwards; Caterham, Champion; Cheltenham, on heath, Marshall; near Whitstone, Devon, Prifitt; Barmonth, Blutch; Armagh, Johnson; Isle of Wight, September, plentiful on Pulicaria, Douglas and Scott; Hayling Island, Weybridge, Billups; Parley Heath and Glanvilles Wootton, Dorset, Dale.

S. pedestris, Fall. (sabulosus, Schill.).-Testaceous browu, somewhat shining, strongly punctured, clothed with rather long pale hairs; head, disc of the pronotum, scutellum, and apical joints of the antenne and abdomen darker; head short, wide; eyes not very prominent, but projecting beyond the anterior angles of the pronotum; antennæ finely pilose, second and apical joints subequal in length, third slightly shorter; pronotum subtrapeziform, sides slightly sinuate, finely carinate, anterior margin not reflexed or raised, surface deeply punctured, rather less coarsely on the darker portion; scutellum dark, paler at the apex, deeply punctured; elytra with the corium and clavus punctured, irregularly clouded with darker brown; membrane pale smoky, slightly darker between the nervures; abdomen pitchy black; legs clear testaceous; anterior femora beneath with a few fine spine-like hairs.

L. $2 \frac{1}{2}-3 \mathrm{~mm}$.

Common and generally distributed in moss, at roots of grass, by sweeping, etc.

S. arenarius, Hahn.-Dull reddish brown, clothed with very short pale adpressed hairs; head, basal and apical joints of the antenne, pronotum in front, scutellum and 
various spots on tho elytra, the abdomen and femora, darker. In shape much like petestris, but rather more parallel-sided and compact, its surface quite dull, the puncturation finer, the pronotum a trifle shorter, with the sides straighter and the base shorter in proportion to the anterior margin, giving it a more quadrate shape; elytra with the membrane smoky, the base and the nervures pale, showing rather vividly against the darker ground; legs with the femori dark except at the apex, anterior pair with a fer stiff hairs along their underside.

L. $2-3 \mathrm{~mm}$.

Common and generally distributed in moss, at roots of grass, etc.

\section{PERITRECHUS, Ficb.}

A genus of numerous species, most of which are so closely allied that it is donbtful whether they should be treated as distinct or only as races of one variable species. This condition of things exists also in Scolopostethus, and I have in this work given all the so-called species as distinct in both cases, without intending thereby to express my opinion that they really constitute species of equal value to those recognized in other genera, but in order that Hemipterists may have the opportunity of judging for themselves as to what they consider the value of a species in such genera.

Faco triangular; eyes large, or medium-sized, projecting more or less beyond the pronotal angles; antenniferous tubercles angular at the sides, rostrum reaching to the intermediate coxi; pronotum trapeziform, sides behind the middle narrowly foliaceous and pale, base sinuate; scutellum with a distinct central line; elytra with the membrane fully developed; legs with the anterior femora more or less incrassated, armed beneath with one or two fine spines; tibix simple, without bristles, or with a few on the inner apical margin of the posterior pair in lunigev. 
(2) 1. Front femora with one spine, membrane with a distinct white apical spot

(1) 2. Front femora with two spine
without an apical spot.

(4) 3. Antenna thinner, tibia entirely pale, cyes prominent .

(3) t. Tilite more or less darti

(6) 5. Antenna thimner, eyes less prominent, pronotum strongly transverse .

(5) 6. Antenn thicker, eyes very prominent, pronotum less transverse, three-quar: ters as long as wide

LUNIGER.

GRACILICORNIS.

NUBILES.

P. luniger, Schill.-Head black, punctured; antenne black, with the base of the second joint red; pronotum punctured, subtrapeziform, not so much widened posteriorly as in the other species, sides nearly straight, foliaceous and pale just behind the midale; dise black in front, widely ochraceous posteriorly, and punctured with black; scutellum black, punctured, with a smooth narrow dorsal line slightly raised at the base, apex narrowly pale; clavus and corium punctured with black in lines, the latter with the intervals between the nerves black posteriorly, leaving a small pale spot at the apex of each; external apical angle black; membrane dark fuscous, a spot at the base and apex, and the bases of the nervures near the outer angles white; abdomen black, clothed with fine golden pubescence ; legs with the apices of the femora, and the front tibia except at the apex, reddish; front femora with a single tootl.

L. $4 \mathrm{~mm}$.

Not uncommon, and from various habitats; in heaps of grass, Woking; at roots, Deal ; in heathy places, Norfolk, Ertwreme; underealine plants Milford Haven, South Deven, Cornwall, Marshull; Knowle, Coleshill, Blatch; Hastings, Battle, Shalford, Butler; Morayshire, Forres; St. Ives and Scilly Isles, J. T. Mason; Dartmoor, Parfitt; Mickleham, Caterham, Chcmpion; Oxshott, Surrey, Billups; Downderry, Cornwall, Bignell; Parley Heath and Bournemouth, Dale. 


\section{Lygaide.}

P. nubilus, $F$ all.-Rather paler in colour than the preceding. Head finely punctured; antenne longer, entirely black; eyes not prominent; pronotum much widened posteriorly, nearly twico as wide as long in somo of specimens, sides narrowly retlexed, with a very small white patch behind the midale, surface punctured, black in front, posteriorly ochreous, with black punctures; scutellum black, with an impressed dorsal line, and a pale V-shaped spot at the apex; clivus with rows of black punctures, corium ochreous, irregularly punctured and spotted with black, leaving the nerves pale; mombrane greyish brown, nerves and an iudefinitely-shaped basal syot white; legrs black; apices of the femora, the anterior tibia, and the apices of the other pairs, as well as the bases of all the tarsi, ferruginous.

L. 5-5. $\mathrm{mm}$.

Herne Bay, at roots of maritime plants in a salt marsh; Whitstable, Deal, Sorthend, Chompion; Norfolk, Edwurds; Penarth, South Wales, and Ashdown Forest, Billups.

P. gracilicornis, Put.-Like the preceding, except that the head is strongly punctured, the eyes are larger and more prominent, the pronotum rather louger, and less widened posteriorly, and all the tibia and tarsi testaceons.

L. $5 \mathrm{~mm}$.

Hastings, Douylas.

P. geniculatus, Haln. (puncticeps, Thoms.).-Like the two preceding, but differing from both in the decidedly thicker antenna; from gracilicomis also in having the bases of the second and third pairs of tibir dark, and in the slightly longer pronotum; and from nubilus in the large prominent eyes, strongly punctured head, and much longer pronotum.

L. $5 \mathrm{~mm}$.

In rubbish, moss, dead leaves, at roots of grass, etc., 
Wuking, Reigate; New Forest, Southend, Champion; Bexhill, Butlev; Norfolk, Elwurds; Headley Lane, Ashdown Forest, Cowbridge South Wales, Billups.

\section{TRAPEZONOTUS, Fieb.}

Species depressed, oval or oblong-oval. Head broad, across the eyesabout equal to the width of the anterior margin of the pronotum; eyes not prominent, touching the pronotum; ocelii small and distinct; autenniferous tubercles small, not prominent at the sides; pronotum with the sides slightly rounded, very narrowly and evenly foliaceous throughout, base largely sinuate; scutellum rather largo; elytri more or less rounded at the sides; membrane complete, or more or less shortened; legs with the anterior femora much incrassated, beneath with two spines and a series of bristly hair's.

Somowhat like Peritrechus in some respects, but easily known by the flatter, wider form and narrow foliaceous lateral margins of the pronotum.

There are six l'aloarctic species, of which we have three in this comtry.

(2) 1. Leggs without spiny hairs . . . Distiaguendus.

(1) 2. Legs with spiny hairs on the tibix.

(4) 3. Basal joint of posterior tarsi only slightly longer than the other two together . AGRESTIS.

(3) 4. Basal joint of posterior tarsi nearly twice as long as the other two togetler. .Ulnicin.

T. distinguendus, Flos. (alistinctus, D. \&. S.).-Elongate oval. Head bronzy black, finely punctured, with a smooth impunctate line on each side of the central lobe; antenma black, the centre of the third joint slightly reddish; pronotum flat, punctured, brouzy black in front, ochreous, punctured with black posteriorly, sides regularly but slightly rounded, margins very mirowly palo and foliaceous, base largely simuate; scutellum black, with an ochreous $V$-shaped apical spot; elytra with the clavus aud corium dull ochreous, punctured with black, the latter 


\section{Lygaida.}

more or less spotted and suffused with black towards the apex, membrane pale smoky brown, base and nervures white; abdomen bronzy black; legs with the femora black, their apices reddish; tibio and tarsi reddish brown; anterior femora beneath with two spines and several bristly hairs; all the tibire without erect bristles.

L. $3 \frac{1}{2}-4 \mathrm{~mm}$.

Rare and local; Worthing; Shoreham and Whitstable, Champion; Ventnor, Lewis.

T. agrestis, Fall. (var. dispai, Stâl).-A much broader and shorter species than the preceding. Head black, antennæ entirely black, except in the of, which has the basal joint testaceous; pronotum with the sides very slightly siuuate, narrowly pale and folinceons, base deeply sinuate, surface punctured, black in front, bright pale ochreous across the base, punctured with black; scutellum eutirely black; elytra with the clavus and corium punctured with black in rows, the latter with a subquadrate spot near its inner apical angle, membrane black with the nervures white; abdomen black, a spot near each coxa and the posterior margin of the metasternum pale; legs, front pair in male testaceons, in $q$ with the femora more or less black, second and third pairs with the femora testaceous in the of with a subapical black band, black in the o; tibix black or with the intermediate ones more or less rufescent; tarsi black.

L. $3-5 \mathrm{~mm}$.

A large pale and brightly coloured form is known under the name of clispar, Stal, but I can really see no characters except colour and size to distinguish it by.

Common in many places at roots of grass, in rubbish, ete. Reigate, Woking, Deal; Norfolk, Euluemls; Exmouth Devon, Parfitt; Folkestone, Iige; Moraysuire, Forres, O. M. Ticuter"; Ireland, Ifaliduy; Chobham and Chertsey, Billups; rar. dispar, Darenth Wood, Douglus.

T. Ullrichii, Fich,-Larger than the preceding, and II 2 
more narrowed posteriorly, antenna more slender, especially the apical joint, second joint pale especially beneath; entire surface rather more shining; pronotum less deeply sinuate posteriorly, its puncturation and that of the elytra finer and not so black, membrane narrower and paler; connexivum narrowly pale; all the tibix and tarsi and the apices of the femora testaceous; basal joint of the posterior tarsi very loug, nearly twice as lung as the other two together, front femora with two larger teeth and several very short ones.

L. $6 \mathrm{~mm}$.

Clitts mear Boscastle, Cornwall, Rev. T. A. Murshall.

APHANUS, Lap.

$$
\text { (Pachymerus, Lur.; Culyptonotus, D. \&. S.) }
$$

This genus contains numerous species, differing considerably in ficies and colour, which differences have given rise to several subgenera, the characters of which I have indicated in the table of species. It may be known from its nearest ally, Bcosms, by the greater width of the pronotum in proportion to the head and the less prominent eyes, and from tiaprenutus by the long basal joint of the tarsi.

Head short, triangular, eyes touching or nearly touching the pronotum, face in almost the same plane as the vertex, except in Rolundri, in which it is distiuctly more declivous ; antenniferous tubercles only slightly developed, ocelli distinct; first joint of the antenua projecting for about a quarter to half of its length beyoud the apex of the face; pronotum wide, flat, its lateral margins foliaceous, either widely pale or very narrowly so or entirely black, more or less regularly rounded; scutellum large; elytra with the clavus variously punctured, membrane complete ; legs, front femora spined, pusterior femora simple or with a small spine near the apex in yrdestris, tibia bristly, or nearly smooth in Iivlantri, basal joint of the posterior tarsi twico as long as the uther two together. I'here are twenty-five 


\section{Lygazide.}

species given in Puton's Catalogue, of which we Lave five indigenous to this country.

(2) 1. Thorax entirely black, face more declivons, clavus irregularly punctured (Subg. Cutyptonotus,

(1) 2. Thorax not entirely black, face les declivous,

Rolaxti. clavas punctured in lines.

(4) 3. The two external rows of punctures on clavus parallel and close together, scntellum with a pale $\mathrm{V}$-slaped apical spot (Sulgr. (iruptopeltus, Stall)

(3) 4. The two external rows of claval pucctures not parallel but divergent in the middle or near the apex (Tanthochitus).

(6) 5. Sides of pronotum entirely and widely pale, membrane dark in the centre (Subg. Ianthochilus, Stal) pronotum not widely nale, membrane

(5) 6. Sides of pronotum not widely pale, membran
black or spotted (Subg. Parhomerus, Reut.).

(8) 7. Legs yellow with black markings, posterior femora dentate at apex . . . PEDESTRIS.

(7) 8. Legs black; posterior femora simple . . . PINI.

QUADR $₫$ TUS.

$$
\text { (SuBg. CALYPTONOI'US, D. \&. S.) }
$$

A. Rolandri, Lin.-Black, dull, glabrous, punctured, a spot at the base of the membrane ferruginous. Head short, indefinitely punctured, eyes not touching the pronotum; pronotum flat, its sides depressed, foliaceous, slightly rounded, base deeply sinuate, disc punctured on its basal half; scutellum punctured; elytra with the corium and clavus irregularly punctured, the nerves sometimes brownish, membrane black with a reddish spot at its base; legs with a row of bristles on the inner sides of the tibia and a few finer ones on the outer; anterior femora rith a strong triangular spine.

L. $5 \frac{1}{2}-6 \mathrm{~mm}$.

Darenth under refuse, Douglas and Scott; Dartford, Plımstead, Champion; Nervton and Exeter, l'arfitt; Portland, Dale.

(Stba. GRAPTOPELIUS, Stâl.)

A. lynceus, Fab.-Broad, subovate, ochreous, punctured with black; sides of the pronotum pale, impunctate; lead, 
pronotum in front, scutellum, except a V-sbaped apical spot, and a spot on the corium at its inner apical angle, black, the black spot having a small distinct whitish one at its apex; legs black, abdomen beneath with a pale spot near each coxa and the posterior margins of the pro-and metasternum oclireous. Head with the eyes touching the pronotum; pronotum with the sides rounded, base slightly sinuate; disc largely punctured across the base; scutellum puuctured; clavus and corium punctured, the punctures arranged more or less in lines; membrane fuscous, more or less spotted and suffused with white; intermediate and posterior tibia bristly, anterior femora with a stroug tooth near the apex in a row of small short ones, base of their tibico outwardly ferruginous.

L. $6-6 \frac{1}{2} \mathrm{~mm}$.

In moss, Deal; Dartford Heath, Scott; Islo of Wight, Puscoe; Shirley, Donglas and Seott; Sandhills, Camber, E. P. Collett; St. Ives, Commall, J. E. Muson; Southend, New Forest, Champron; Hunstanton, Fowler; Margate, Billips.

(SøBG. XANTHOCHILUS, Stâl.)

A. quadratus, $\mathrm{Fa}$. -Elongate oval, ochreous, punctured with dark brown, sides of pronotum aud corium impunctate. Head black, antenno, first jointblack its apex reddish, second and third dull red, darker at their apices, apical joint dark; pronotum with a quadraugular spot in front black, sicles widely foliaceous, pale impunctate, base ochreous; scutellum black; corium with a somewhat elougate black spot on each sile just above the membrane; membrane white with a brown central streak; abdomen black, a spot near each coxa and the posterior margin of the metathorax pale; femora black, their apices red; tibia reddish, their apices darker. 


\section{Lygride.}

I. $5 \mathrm{~mm}$.

Very rare, Llandudno.

(SodG. PACHYMERUS, Teut.)

A. pini, Lin.-Somowhat like lyncens in general colour, but more elongate oval. Head black, irregularly clotled with short adpressed golden hairs, eyes touching the pronotum, autenur black; pronotum flat, with the lateral margins slightly rounded, very narrowly pale and foliaceous, base sinuate, disc in front black, behind ochreous, punctured with black; scutellum black, with a distinet slightly raised central line; corium and clavus ochreous, punctured with black, more or less in lines, a dark line on the clavus near the scutellum and a subquadrate spot near the inner apical angle of the corium black; membrane black; abdomen black, a spot on the prothorax beneath near its posterior angle, its posterior margin, the posterior margin of the mesosternum, and a spot near each coxa, ochreous; legs black, tibire finely spinose, anterior femora with two small teeth, close together, near the apex.

L. $7-7 \frac{1}{2} \mathrm{~mm}$.

In sandy, heathy places, Woking, Chobham; Erwhurst, Gomshall, Chingford, Butter; Norfolk, Ectwards; Poole, Dorset, Blatch; Bridgnorth and Edgbaston, Marshall; Shirley, East Grinstead, New Forest, Champion; Addington Hills, Douglas and Scott; Ashdown Forest, 'Taff's Well, South Wales, Billups; Bournemouth, Knighton Heath, Land's End, Dale.

A. pedestris, Panz,-Bright ferruginous, with black and white markings. Head black, puuctured, with a few long scattered hairs, eyes not tonching the pronotum; antennæ black, the second joint and the extreme aper of the first testaceous; pronutum subtrapeziform, sides nearly straight, foliaceous, bearing a row of distant long hairs; base deeply sinuate, disc with a few scattered hairs, anteriorly black, posteriorly ferruginous, punctured with 
brown, posterior angles black, a spot in front of them white; scutellum black, corium and-clavus ferruginous, punctured with brown, a line down the centre of the latter, and the former outwardly and apically white, with a round black spot near the aper, membraue black, white at the apex; abdomen black; posterior margins of the thoracic segments beneath pale, ablomen beneath clothed with fine hairs; legs testaceous, a band at the apex of each femur, the apex of the anterior tibio, the base and apex of the others and all the tarsi at the apex black; anterior femora with a strong spine towards the apex aud two smaller ones on its proximal side, intermediate and posterior femora with a small tooth close to the apex.

L. 5-6 $\mathrm{mm}$.

Not common, Clobham, ruming among dead leaves, etc, on a dry saudy bauk; ;ead leaves, Ashford, Kent, Harshull; not uncommon muder bark of whitethorms, etc., Norfolk, Eluchils; Colchester, Walton-on-Naze, Croydon, Blutch; Stoke Wood, Devon, I'afitt; Gravesend, Southend, Lee, Darenth, Chatham, Champion; Cardift, Billuss; Portland, Dale.

BEOSUS, Am. S.

$$
\text { (Dienches D. S. S., Saund. etc.) }
$$

Allied to Lphanus, but easily distingnished by its narrow form, the prominent eyes, which project beyoud the anterior margin of the pronotum, and the longer, thinner basal joint of the antenna.

There are three European species, of which we have only one in Britain.

B. luscus, Fib.-Elongate pale ochreous, punctured and spotted with black. Hcad black, clothed with a silvery adpressed puhescence, eres uot quite touching the pronotmm, antenno, fir:t joint black, pale at the extreme base, second and third ochreons, black at the apex, fourth black, ochreous at the base; pronotum with the sides very slightly 
curred, widely foliaceous and raised, ochreous and impunctate; a large subquadrate spot on the front of the disc black and clothed with silvery pubescence, except a spot on each side of its centre, which is glabrons; the dise posteriorly is ochreous, punctured with black, posterior angles black; scutellum black with a pale line on each side of the apex; elytra with the clavus and corium ochreons, punctured with black, a large band near the apex and the apical margin of the latter black; abdomen black, clothed with silvery hairs, posterior margin of the pro- and metasternum and a spot near each coxa pale; legs ochreous, femora with a broad black band, anterior pair with a sharp tooth beneath.

L. $6-6.1 \mathrm{~mm}$.

This beautiful insect is generally rne, I have found it near the Land's End and at Dawlish, Devon. The Rev. T. A. Marshull observes, "Rather common on the Cliffs of Milford Haven, under tufts of Silene maritima, on which it appears to feed; by searching the same plant on the Cornish coast, I have found two or three here ;" St. Ives, Cornwall, J. E. Mason; Whitsand Bay, near Plymouth, J.J. Walker; Parley Heath, Dale; Bridgend, South Wales, Billups; Portlemouth, Wembury, Bignell.

\section{EMBLETHIS, Fich.}

A genus easily known by its uniform pale ochreous blackpunctured surface and bristly legs and antenna. Head short, eyes touching the pronotum, antenniferous tubercles obtuse laterally, first joint of the antenno scarcely extending beyond the apex of the face; pronotum broad, flat, sides widely foliaceous; elytra with the sides slightly rounded; legs and antenua bristly, the anterior femora beneath with a row of very short spine-like hairs.

There are nine recorded Palæarctio species.

E. verbasci, Fab.-Oval, ochreous, finely and closely 
punctured with brown, margins with larger black punctures more or less grouped. Head with a few short bristles, especially near the apex of the central lobe ; rostrum piccous, antenna obscure ochreous, bristly; pronotum broad, flat, anterior margin and base slightly sinuate, sides slightly rounded, largely foliaceous and punctured with large black punctures, dise finely punctured with brown; scutellum finely punctured, with tro little brown spots near each basal angle; elytra, clavus and corium finely punctured, the latter with its sides foliaceous and punctured with large black punctures more or less grouped; membrane pale, with brown clouded spots; abdomen reddish ochreous, connexivum spotted with black, thoracic segments beneath black, tho posterior margins of each aud the anterior margin and centre of the prosterum pale ochreous, as well as a spot near each coxa; legs, femora spotted with brown, tibire bristly, posterior metatarsus more than twice as long as tho other two joints.

L. $6 \mathrm{~mm}$.

Very rare. Sandhills, Deal.

\section{EREMOCORIS, Fieb.}

A very distinct genus, of closely allied species, which has beon carefully studied by Dr. Horváth, aud its dificulties ably cleared up.

Head rather long, antenniferous tubercles distinct, basal joint of the antenne extending beyond the apex of the face for more than half its length; eyes not tonching the pronotum; anterior margin of the pronotum deeply sinuate somewhat raised, sides sinuate or rounded, disc laterally impressed behind the middle; sides of the elytra slightly rounded, membrane usually complete; anterior femora incrassated, toothed beneath, their tibia more or less curved; mesosternum bituberculate or simple. Puton gives seven European species, of which we have three. 


$$
\text { Lygreida. }
$$

(2) 1. Basal joint of posterior tarsi more than twice as long as the second and third together. FEMESTRatus.

(1) 2. Basal joint of posterior tarsi not twice as long as the second and third together.

(4) 3. Mesosternum hitulerculate, hairs of tibio

shorter, not at right angles to the tibio . - rodagricus.

(3) 4. Mresosterum simple, tibial hairs longer, erect . PLiBerus.

E. fenestratus, M. Schf. (erraticus, D. \& S.; poctugricus, Saund. Synops.).-Head and pronotum black, somewhat shining, shallowly punctured, nearly glabrous, the latter brown across the base, where it is more largely and deeply punctured, sides slightly rounded, foliaceous, pale, especially behind the middle, posterior angles black, base deeply sinuate; scutellum black, punctured, depressed at the base, slightly cariuated at the apex; elytra long, nearly parallelsided, with the clavus and corimm punctured, more or less ochreous at the base, reddish brown towards the apex, with a roundish black spot near the centre; membrane dark fuscons, a spot near the aper of the corium and one opposite to it and the basal angle white; abdomen black, connexivum and apex paler and reddish, posterior margins of the pro- and metasternum pale as trell as a spot near each cora; legs, femora black, paler at the extreme apex, tibir obscure ochreous, with a few erect hairs on the posterior pair, anterior femora with a strong central tooth arising from a row of smaller ones, their tibix curved; posterior metatarsi a good deal more than twice as long as the other two joints together.

L. $7 \mathrm{~mm}$.

Reigate, under Junipers; Caterham, Mickleham, Chatham, Champion; Dartmoor, July, Parfitt; Croydon and Hunstanton, Blatch.

E. podagricus, Fab.-Shorter and broader than the preceding; elytra distinctly shorter and with its sides more rounded; pronotum more trapeziform, with its sides sinuate, surface dull, clothed with semi-erect pubescence, coloured much as in fenestiatus, only the colours rather brighter; 
scutellum, clavis and corium clothed with fine semi-crect pubescence like the pronotum, the scutellum black, the clavus and corium ochreous at the extreme base, more or less mottled with black and browu, no distinct central spot, membrane dark fuscons, a small transverse spot on each side and the nervures pale; Iegs clothed with fine semierect hairs, anterior femora with two louger spines, their tibia much curved, mesosternum with a tubercle in front of each coxa, largest in the $\delta$.

L, $5-6 \mathrm{~mm}$.

Littlington, Cambridge, under dead leaves at the bottom of a hedge, J. 1. Power.

E. plebeius, Full.-Very like an obscurely coloured podagricus, the hemelytra being entirely of a uniform brown, paler at the base, with a very small black spot near" the centre, membrane dark with three paler spots at the base; mesosternum simple, tibix, especially the posterior pairs, with long erect hairs as well as the shorter semi-erect ones.

L. $5-6 \mathrm{~mm}$.

Forres, G. Norman; Taff's Well, Billups.

\section{SCOLOPOSTETHUS, Fieb.}

About this most difficult genus a great deal has been written, and different authors have put value on different classes of characteristics as affording specific distinctions. Mr. Edwards relies on the colour of the antenux, etc., as offering stable characters, and on the form of the genital styles in the $\delta$. Dr. Horvath relies on the form of the pronotum, the pubescence of the surface and the development of the membrane; he admits the value of the form of the styles, but thiuks it unnecessary to employ a character so difticult to examine. Personally I attach little value to colour when it is a question between testaceous and black, as it is in this geuus, as I feel convinced that an unusually rapid passage through the pupal or nymph state 
tends to impede the development of black. This, I feel little doubt, is the explanation of the red-bodied forms of Antrena in the Hymenoptera, occurring more commonly in hot dry summers than in cold damp ones; and in the genus now under consideration, one species at least, S. neglectus, varies in the amount of black on the second antenual joint. I have specimens with a broad black band at the apex, others with a very narrow one; and why others should not occur without a band at all I fail to see. On the form of the styles in the $\delta$ I place great value, but I can only detect differences between three of the forms of style I have examined, and the differences which exist between these appear to me to be traceable to modifications of a common form; at the same time, they are distinct enough for practical use, and therefore should not be put aside. Grouping them by the form of the styles, I should unite affinis and grandis; puberulus and neglectus; decoratus remaining distinct; of pictus the style has not been examined. The characters of the form of the pronotum and mernbrane seem to me most unreliable, as both these vary in form correlatively with the development of the wings; and to be certain that a pronotal difference between any two of these insects is reliable, one must be certain that the wings are equally developed in both, a position very laard to obtain. As an instance of variability of the length of the membrane in the brachypterous form, I may mention that I have one example of puterutus, Horv., in which the membrane projects beyond the apex of the corium by about half its diameter, and I have another, in which it hardly projects beyond the apex of the corium at all, and yet both were taken in the same bateh, and are clearly identical. After very careful consideration, I feel no doubt that all the so-cutled species are races of one, still they are recognizable as a rule, and therefore I givo them; other characters may yet present themselves to distinguish them apart more satisfactorily. 
The genus may be thus characterized: Head with the eyos not quite touching the pronotum, and not contracted behiud them, eyes rather prominent, antenniferous tubercles not produced laterally, face triangular, sharply pointed in front, the central lobe much longer than the cheeks, basal joint of the antenna extending beyond the apex of the head for about a third of its length; rostrum reaching to the intermediate coxas; pronotum more or less trapezoidal in most cases, but nearly square in others, this character varying with the development of the wings; lateral margins more or less sinuate, pale and foliaceous just behind the middle; elytradeveloped, with the membrane full and reaching beyond the apex of the abdomen, or with it curtailed, exhibiting the terminal seguents; legs with the anterior femora incrassate, bearing a large spine beneath and a series of small ones between it and the apex; mesosternum simple, or with two tubercles in front of the cosa, long and curved in the $\delta$, short in the $q$.

(2) 1. Antenno louger, pale throughout, large tooth of anterior femora situated about the midale

(1) D. Antenna shorter, rarely pale throughout, large

PICTCS. tooth of the anterior femora nearer the apes than the midule.

(6) 3. Mesosternum tuberculated in front of the intermediate coxa?

(5) 4. Pronotum wider posteriorly, membrane in the unleveloped form scarcely produced beyond the apex of the corium . . .

(1) 5. Pronotum narrorer posteriorly, mombrane in the undeveloped form produced for at least half the length of its diameter beyond the apex of the corium.

(3) 6. Mesosternum simple.

(s) 7. First and second joints of the antennx longer, surface more distinctly pilose . . . JUBERULUS.

(7) 8. First and second joints of the antenno shorter, surface glabrous, or scarecly pilose.

(10) 9. First aud secoud joints of the antenne pale, except the apex of the secoud; alinust always undeveloper and slightly pubescent . the extreme base of second; alnost always developed, and practically glabrous . - Decoratus. 
S. pictus, Schill.-Head black, with a few large punctures; antennæ entirely testaceous, long and slender; pronotum trapezoidal in the developed form ( $\mathrm{I}$ have never seen a brachypterous one), anterior margin very narrowly constricted, red, sides very slightly sinuate, pale, widely foliaceous and pale behind the middle, posterior angles brown, base sinuate; dise black in front, ochreous, punctured with brown posteriorly, with a brown cloud on each side of the pale baso-dorsal line; scutellum black; elytra with the corium and clavus ochreous, punctured with brown in lines, a broad band at the apex of the corium, a spot on its lateral margin, and a dark line just within the latero-diseal nerve, dark chocolate brown; membrane milky white, nervures brown; leg's testaceous, anterior femora with the large tooth situated about its middle, between which and the apex $\mathrm{s}$ a row of small, very fine ones, tibire curved, in the of considerably, with a few denticulations near the apex inwardly.

L. $5 \mathrm{~mm}$.

Rare. Horning Fen, Brower; Littlington, Cambridgeshire, February, Power; Glanvilles Wootton, July, and Charmouth, Dale.

S. affinis, Schill. (adjunctus, D.\&S.).-Like the preceding in general colour and pattern, but with the antennæe shorter and thicker, the third and fourth joints black; the membrane often undeveloped, and the wings curtailed, the membrane being scarcely produced beyond the apex of the corium, and the pronotum in consequence being narrower posteriorly; the anterior femora with the large tooth nearer the apex, and with a broad black band; posterior femora also occasionally with a black apical ring; mesosternum beneath with two curved horn-like tubercles, in the of blunt at the apex, in the of with tro small raised points.

L. $4-4 \frac{1}{2} m m$.

Common in rubbish, by sweeping nettles in summer, etc. S. grandis, Horv. ( punctutus, Edu.), differs from the 
preceding in having the antenno with tho second joint pale at the base, and gradually darkened to the apex; in having the pronotum in the undeveloped form wider anteriorly and consequently squarer; and in having the membrane more produced, the part produced beyond the apex of tho corium being lialf as long as the diameter of the membrane; the mesosternal tubercles are as in affinis, and I can see no difference between the forms of the gemital styles in the two species.

L. 4. $\mathrm{mm}$.

Woking, under rubbish, and Chobham; probably elsewhere, but overlooked.

S. puberulus, Horv. (adjunctus, Elw. nec D. \&. S.).-Liko all the others in pattern, but with the metasternum simplo in both sexes, the first and second antennal joints entirely pale, and longer than in most of the forms; the surface clothed with fine short hairs, observable chiefly near the hind angles of the pronotum and on the exterior portion of tho corium; legs pale, front tibio rather less curved in both sexes than in the three prececting; in this species the blade of the genital style is distinctly broader towards the apex than in the two precediug.

L. $4 \mathrm{~mm}$.

Norfolk, Thouless, and Bexhill, Butler; Oreston, Bignell.

S. neglectus, Litw. (affinis, Stand. Synons.), differs from tho preceding in having the apex of the second joint of the autenna wore or less black, and the first and second shorter and rather thicker at the apex, and with the pubescence of the surtace slorter (I only know the undeveloped form); posterion femora with a black ring; genital styles as in puborulus.

L. $3 \frac{1}{2}-1 \mathrm{~mm}$.

Not uncommon by sweeping, ctc., but rarel than afinis.

S. decoratus, Hahn. (ericetoram, Letho).-Quite glabrous and with the autemno black excopt at the base of the second joint; nearly always developed, I have only seen oue other- 


$$
\text { Lygrida. }
$$

wise; prosternum less strongly punctured at the sides than in the other species, femora with a black ring at the apex.

L. $3 \frac{1}{5}-4 \mathrm{~mm}$.

Common and generally distributed on heaths.

\section{NOTOCHILUS, Fieb.}

Closely allied to Scolopostethus, but readily recognized by the shape of the head, the eyes being remote from the pronotum, and the head narrowed behind them into a short neck; surface deeply punctured; pronotum with a deep central impression; lateral margins narrowly reflesed; scutellum with a distinct basal impression; front femora strongly toothed.

N. contractus, $\pi$. S.-Black, a small pale spot on each side of the pronotum; corium and clavus dull ochreous, the apical two-thirds of the former brown, with a smail pale spot ontwardly; membrane greyish-brown, pale at the base, the nervures darker. Head closely and deeply punctured; antenna with the first joint extending for more than half its length beyoud the aper of the face; pronotum twice as wide at the base as at the anterior margin; sides sinuate, narrowly pale and reflexed, the reflexed portion wider behind the middle; dise with a wide central longitudinal impression ; scutellum deeply punctured, impressed rather deeply at tho base; elytra punctured on the corium and clavus; abdomen black; legs dark brown; anterior femora incrassated, with a row of many teeth beneath, including two much stronger and longer than the rest.

L. $2 \frac{1}{2}-4 \mathrm{~mm}$.

Generally distributed and common by sweeping among nettles, in rubbish, moss, ete.

N. limbatus, Ficb. (crassicomis, D. S. S.).-Feruginous; head and front of pronotum fuscous, extremobase and hind angles of latter also dark; antenux basal joint red, the rest black, except the base of the secoud and apex of fourth; 
elytra with a broad band across the middle, interrupted by the claval suture and the discal nerve, and the apical margin narrowly black; membrane dusky, with a pale streak on each side along the margin of the corium; legs red, apices of the femora narrowly black; segments of the thorax benenth pitchy. Head rugosely punctured; antenniferous tubercles rounded and shiming; basal joint of the antenure elongate, as long as the second, secoud and third cousiderably widened at the aper, fourth about equalling the third in length; pronotum not much widened behiud, sides slightly siuuate, surface rugosely punctured; disc more or less raised on each side, leaving a broad somewhat impressed dorsal line; scutellum punctured, with an elevated line at the apex; elytra punctured in lines on the clavus, and with a line of puuctures along the claval suture of the corium, disc with hardly visible punctures; abdomen smooth and shining, with only very fine scattered punctures; anterior fewora much incrassated, with a row of fine spines towards the apex, with a larger one in their centre; those on the proximal side of the large one smaller than the others; thoracic segments beneath rugosely punctured.

L. $3 \frac{1}{2}-4 \mathrm{~mm}$.

Southsea, May, 1870, one o, Moncreaff; Berrdley Forest, in a sandy place, wargin of Dowles Brook, July, 1879, Blateh.

I have two Continental specimens of this species, in both of which the black band of the elstra is widely interrupted, and in one it is only faintly indicated, so that this character must be regarded as variable.

\section{DRYMUS, Fieb.$$
\text { (partion = Lamproplux, D. s. S.) }
$$

Short, oval, or oblong. Head with the eyes and ocelli tonching or not quite touching tho pronotum; autenniferous tubercles laroge, rectangularly produced laterally; rostrum 


\section{Lysaida.}

reaching to the intermediate coxw; antennw with the apical joint shorter than the second; pronotum with the sides slightly sinuate, narrowly reflexed, base very slightly sinuate; scutellum impressed; elytra with the sides more or less rounded; membrane generally complete; legs with the front femora toothed.

All the species are of a brown colour, and unspotted. Puton records nine European species, of which we have five.

(8) 1. Pronotum dull, panctured anteriorly.

(5) 2. Tibia without projecting hairs.

(4) 3. Pronotum entirely black, minch videned pos-

(3) 4. Pronotum brown at the sides and posteriorly,

not much widened behind. . BRoxwers,

(2) 5. Tibize with long projecting hairs.

(7) 6. Abdomen beneath dull, closely punctured - PTLrPEs.

(6) 7. Abdomen beneath shining : PILICORXIs.

1) 8. Pronotum anteriorly shining, impunctate, or nearly so . . . . PICEUS.

D. sylvaticus, Fab. (var. Ryei, D. \& S.). -Short, oval, black, closely punctured; hemelytra brown, or ochreousbrown. Head with the eyes not quite touching the pronotum, strongly and rugosely punctured; antennæ finely pilose, apical joint subequal to, or hardly longer (var. liyei) than the third; pronotum transverse, widened posteriorly, sides very slightly sinuate, strongly and very closely punctured; disc with a transverse depression near the middle; scutellum punctured like the pronotum, or rather more largelyand remotely, var. Ryci; corium and clavus punctured, ochreous-brown, with a few darker stains, or reddish-brown, var. Iiyei; membrane smoky, nervures slightly paler, or darker with the base pale, and sometimes shortened, var. Iyei; beneath black, finely pubescent; anterior tibia with a small spine.

L. $4-4 \frac{1}{2} \mathrm{~mm}$.

Common in moss, dead loaves, rubbish, etc, and generally distributed; var. Ingei less commou and well marked as a variety. In Scolopostethus it would rank as a species. 
D. brunneus, Safll.-Less regularly oval than the preceding, the pronotum being narrower, and the elytra wider posteriorly, with more rounded sides; the apical joint of the antennio is longer than the third, and pale at the spex; the eyes are more remote from the pronotum, and the face rather longer; the pronotum is brown posteriorly, with the side margins pale and more deeply sinuate and less divergent; elytra of a brighter brown, pale at the base, and grenerally with a pale spot on the corinm near the claval suture; membrane dusky, nervures pale; legs brown.

I. $4 \mathrm{~mm}$.

Common, though not generally so common as syluaticus, in similar localities, and with an equally wide range.

D. pilipes, Fiel-CMuch larger than either of the preceding and more elongate, resembling a lihyparochiomus in shape more than a Diymus; head, pronotum, and scutellum black; side margins of pronotum, the elytra, and legrs brown; elytra pale ochreous at the base. Head with the eyes not touching the pronotum, punctured; antenna with long projecting hairs; pronotum trapeziform; lateral margins slightly sinuate, surface deeply puuctured, with a slight transverse discal impression; scutellum largely punctured with a strong basal impression; elytra with the clavus and corium punctured, the latter pale ochreous at the base; membrane pale, nerrures slightly darker; abdomen black, dull ; apex piceous, clothed with fine hairs, and finely punctured; legs brown, femora darker, anterior pair with a strong tooth and several small ones between it and the apex, their tibie strongly curved; all the tibia with long erect hairs.

L. $5-5 \frac{1}{2} m m$.

Rare, Betchworth, Surrey, on a willow tree; Stoko Hill, Devon, I'urfitt; Nickleham and Chobham, Billups.

D. pilicornis, Auls. (lutus, D. \& S.').-Thather like the preceding, and of the same elongate form, with similarly 
pilose antenno and tibia; but the pronotum is more narrowed in front in the o, and brown across the base in most specimens; the scutellum is less strongly impressed at the base, and the corium is unicolorous throughout, and of a brighter redder brown; the membrane is dart fuscous, paler at the inner angle; the abdomen beneath is smooth and shining; and the femora are clear testaceous brown, like the tibix; anterior femora less strongly curved.

L. $5-5 \frac{1}{2} \mathrm{~mm}$.

Hurst Wood, Caterham and Sheppey, Champion; in moss, Weybridge, Billups.

D. piceus, Flor.-Unlike any of the preceding, shining, almost glabrous, testaceous brown; head, pronotum in front, and underside darker. Head with a few fine punctures; antennæ clothed with fine hairs, with the basal joint and apex of the fourth clear testaceous, the rest darker ; pronotum subquadrate, deeply and largely punctured posteriorly, convex, pitchy brown and shining anteriorly, the rather widely reflexed lateral margins and basal half testaceous brown; scutellum pitchy brown, the basal impression finely punctured, the sides very coarsely so; apex with a central carina; corium and clavus punctured, the latter in rows, the former irregularly, with a smooth impunctate space along the outer margin and near the centre, between which and the claval suture are two parallel rows of punctures; membrane dusky, sometimes more or less shortened; legs clear testaceous, intermediate and posterior tibice with a fer short bristly hairs, anterior femora with two fine spines.

L. $4 \mathrm{~mm}$.

Rare, at roots of plants at Gracious Pond, Chobham; in moss in Broadwater Forest, near 'Innbridge Wells; Wimbledon, Liye; Scarborough, Lauson; Dublin Loch, near Thornhill, Dumfries, Sharp; Deal, at a ditch side by sweeping, Headley Lane in a swamp, Billups. 


\section{GASTRODES, Westw。}

A genus at once known by its very wide and very fiat shape; the head is small; the eyes and ocelli almost touch the pronotum; the rostrum reaches beyond the posterior coxre the pronotum is flat, with narrowly foliaceous sides, much widened posteriorly; the scutellum is equilateral; the elytra are much widened from the base to about their centre; the membrane is entire; the meso- and metasternum are ver'y strongly furrowed; the auterior femora very much incrassated, finely serrated beneath, with a strong subapical tooth followed by several small ones outwardly; anterior tibia much bent at the base; basal joint of the tarsi subequal to the other two taken together.

Wo have both the European species in this country. 'They occur on Conifers.

(2) 1. Lateral margins pale only posteriorly . PERRUGINEUS.

(1) 2. Lateral margins of pronotum pale through. out their length . . . ABIETIS.

G. ferrugineus, Isinn.-Obscure testaceous red, head and front of pronotum and scutellum black. Head deeply punctured; antenne entirely rufescent, basal joint extending for nearly half its length beyond the apex of the face; pronotum with the lateral margins black in front, slightly sinuate, base largely simate, surface largely punctured all over, dull, with a rather deep transverse impression behind the middle; scutellum punctured all over; elytra with the clavis and corium punctured; membrave dark smoky; abdomen red, thoracic segments beneath black; posterior morgin of pro- and metasternum red, as well as a spot near each coxa; legrs red, anterior femora much incrassated, sorrate beneath, with a strong tooth near the apex; tibia much curved at the base.

L. $6-6 \frac{1}{2} \mathrm{~mm}$.

Not rare on Scotch firs, but local, Woling; Aviemore, Esher, Champion; Leominster, J.J.Walker" Birch Wood, 
and wood near Leicester, Mforshall; Hunstanton, Isle of Wight, Essex, Blatch; Norfolk, Elwarls; Hurst Green, Battle, Nickleham, Butler; Dawlish, Parfit ; Morayshire, Forres, Norman; Ireland, Haliday; Headley Lane, Weybridge, Billups; Glanvilles Wootton, Dale.

G. abietis, Linn.-Like the preceding in form, but rather narrower; the basal joint of the antenna shorter, scarcely extending beyond the apex of the head; the third and fourth joints and the apex of the second are black; the side margins of the pronotum are pale tliroughout, more broadly foliaceous, especially behind the middle; the surface of the anterior portion of the pronotum is more finely and remotely punctured and shining; the scutellum has a shining smooth line down each side; the corium and clavus are pale ochreous at the base and along the inner margin of the former, which is of a more reddish tint outwardly and apically, with an oblong longitudinal spot near the inner apical angle; membrane dusky, with two paler basal spots; anterior femora less incrassated than in ferrugineus, and tho bases of the tibix less bent.

L. 6-6r $\mathrm{mm}$.

Rare. In cones of spruce fir, Woolmer, Wollaston; Merton Park, Norfolk, Edwards; Newnham, Gloucestershire, Fowler; Burton, J. Haris; Worcester, Blatch; Nunton, near Salisbury, Marshall; Perthshire, P'itlochry and Forres, Norman; under bark of spruce fir, Chobham, Billups.

\section{PYRRHOCORINA.}

\section{PYRRHOCORIS, Fall.}

A genus known at once by its bright red and black colour and the absence of ocelli. 'The membrane in our' British species is rarely developed.

There are ten species griven as Palicarctic by Putou, most of which are of southern distribution. 
P. apterus, Lim - Above flat oblong ovate, bright scarlet, punctured. Head, dise of pronotum, scutellum, a round spot in the ceutre of the corium, a very small one near its base and the membrane black, this last usually abbreviated; abdomen black; connexivum and apex of sixth segment red; basal genital segment red beneath; thoracic segments beneath black, their posterior margins and the anterior margin of the prosternum red; a spot near each coxa red; leg's and antenna black.

L. $8 \mathrm{~mm}$.

Torquay, Teignmouth, "in abundance, 1865," Parfitt; Barmouth Sands, Elatch; Cowbridge and Tatf”'s Well, South Wales, Billups.

\section{TINGIDID}

A family of small, mostly oval-shaped, species, peculior by the very large puncturation or reticulation of the upper surface, the integument is often very thin, and more or less membranous; the membrane is puvetured or reticulated much like the rest of the elytra, and the clavus is wanting, except in Piesma. Another strongly-marked character is the great length of the third joint of the antenna, and the shortness of the second; the ocelli are absent, except in Piesma; and the sentell um is covered, except in that genus, by the long angularly produced bise of the pronotum; anterior coxa inserted at the base of the prosternum; the tarsi are two-jointed; the rostrum is three-jointed, received when at rest into a deep chanuel, formed by the under margins of the cheeks and elevated ridges on the pro- and mesosternum, and sometimes also on the metasteruum.

There are two subfamilies, which may be thas characterized:-

1. Scutellum visible, clavus defined, membrane de-

2. Scutedlum covered, clarns and memimane undefined, ocelli wanting . . . . . 'Tisgidis. 


\section{PIESMINA.}

\section{PIESMA, Lep. \\ (Zosmenus, Lup.).}

A genus whose position is somewhat doubtful, as it wants several of the more pronounced characters of the Tingididie, and yet differs from the Lygreite in others; it makes a sort of link between these families, and as it is generally classed with the Tingidicle I have left it there. It may be known from all the other genera by its exposed scutellum, its distinct clavus and membrane, its ocelli, and the form of the cheeks, which are produced in front into distinct horn-like processes.

There are fifteen species given by Puton, but many of them are very closely allied, and some may possibly not retain their specific value.

(2) 1. Pronotum with three keels anteriorly . QUADRaTA. (1) 2. Pronotum with two keels anteriorly : . CAPITATA.

P. quadrata, Fieb.-Pale dull greyish ochreous, more or less spotted with small darker spots, or uniformly ochreous. Oval, head rugose, with a spine in front of each eye, and the cheeks produced, the processes bent, and converging at the apes; antenua with the basal joint very thick, the second slightly narrower and shorter, the third very long and thin, the fourth about equal to the first in length and the second in width; pronotum very strongly punctured, sides dilated and foliaceous in front, showing several rows of fine meshes, slightly rounded; base nearly straight; disc raised posteriorly, with a deep transverse channel in front, which is traversed by three fine carine; scutellum small, raised, pale, and tuberculate at the apex; elytra ivith the corium and clavns punctured like the pronotum; membrano lyyaline, with four parallel nervures; legs ochreous.

L. $2 \frac{1}{2}-3 \mathrm{~mm}$.

Common in many places, especially on the coast, on 
Chenopodirm, and other maritime plants, in salt marshes, etc. Irelaud, Hutiday.

P. capitata, Wolij (var. Laportei, Fich.).-Like the preceding, but naxrower; the pronotum sinuate, sometimes deeply, at the sides, in front with only two carins; tho scutellum rather larger, not tubercnlate and pale at the apex; elytra often with very distinct black spots, sometimes quite unicolorous.

I quite fail, after careful examination, to be able to accept Laportei, Fiel, as a species. Dr. Puton distinguishes it by the larger anterior lobe of the pronotum, showing three rows of meshes at the sides, and the spotted elytra. In my specimens some have three rows of meshes in the anterior sides of the pronotum, some two, some one. Some of those with only one have the elytra quite as darkly spotted as those with three. I have both forms from the same localities; as I can see no satisfactory character to distinguish them, I do not hesitate to unite them, at any rate, until some satisfuctory difference can be found. The shape of the genal processes also varies greatly.

L. $2 \frac{1}{4}-2 \frac{1}{2} \mathrm{~mm}$.

Occurs not infrequently by sweeping, etc., and is generally distributed.

\section{TINGIDINA.}

(2) 1. Sides of pronotum obtuse, elytra simple . Serkntiris.

(1) 2. Sides of pronotum strongly carinated, elytra with its sides foliaceous and reticulated.

(10) 3. Channel, in which the rostrum lies, open in front.

(5) 4. Pronotum simple in front, anterior margin

(4) 5. Pronotum with a more or less raisel hood Campylostira.

(4) 5. Pronotum with a more or less raised
or process on the anterior maryin.

(7) 6. Antennas slender, second joint not rugoso, much narrower than the apical one.

(c) 7. Antennx more or less robust, or with the

Orthostira.

(9) 8. Disc of elytra Hat, nerves only raised . Dictronota. 
(8) 9. Disc of elytra raised on each side to meet

(3) 10. Rostral channel closed in front.: DERermista.

\section{SERENTHIA, Spin.}

(Agramma, D. \& S.)

A very distinct genus, by its long shape and the obtuse sides of its pronotum; the head is rounded and obtuse, with strong antenniferous tubercles, the third joint of the anteuure slightly tapers to its apex, and is about equal in length to the first and second together; rostral canal very large, closed in front; the pronotum is elongate, with the sides straight, the anterior margin emarginate and raised, the base produced in a loug acute angle over the scutellar region; elytra with fine mesh-like punctures; membrane indistinct.

'There are six European species, of which femoralis, Thoms., is quite likely to occur here; it may be known by its larger size, more distinct membrane, and polygonal meshes.

S. læta, Fall.-Small, oblong, three times as long as wide. Head and pronotum black, tho former simply punctured, the latter with large, mesh-like punctures; anterior margin and basal angle pale; disc with an elevated dorsal line throughout its entire length; elytra palo ochreous, simple, without dorsal carinr, closely punctured with round mesh-like punctures; abdomen black; legs testaceous; apical joint of the tarsi black ; edges of the cheeks beneath, which form the sides of the rostral canal, pale, as well as the posterior margin of the metasternum, a spot near each coxa, and a ring round the orifice of the odoriferous sac.

L. $1 \frac{1}{2} \mathrm{~mm}$.

Not rare but local, by sweeping grass, June to Sep. tember, Reigate, Chobham, Woking, Herne Bay; Deal, Norfolk, Elwards; Dunston Common, Coleshill, Clacton, 
Bonnemouth, Blatch; Fairlight, on heath, Butler; Shoppey, Whitstable, Chumpion; 'Tunbridge Wells, Douglus and Scott; Penarth, South Wales, Billupp's; Lulworth, Hodd Hill, Dale.

\section{CAMPYIOSTIRA, Fieb.}

- The very small species which represent this genus may be easily known by the emarginate anterior margin of the pronotum, which bears no hood or central projection; the head has two strongly-marked obtuse antenuiferous processes; the antenna liave the first and second joints short and stout, nearly as wide as loug, the third very loug, the fourth about as long as the first and second togrether", narrow at its base, widening into a club towards the apex; rostral channel open in front; pronotum short, its sides nearly straight, and reticulated, disc with three keels; elytra without distinct membrane, sutures not parallel, membranons, with longitudinal subparallel nerves extending to the apes, the intervals with irregular meshes.

There are four well-known European species mentioned by Dr. Puton in his Catalogue, and two doubtful ones.

C. verna, Full. (brachycera, Fieb.).-Small, elongate oval, brownish, elytra transparent, reticulated. Head testaceous brown, dull, antenna with the terminal joint dark at its apex; pronotum with the sides nearly straight, with two rows of meshes in front, and one behind, anterior margin emarginate, base produced in an obtuse angle over the scutellum, disc tricarinate, largely punctured, its lateral carina not reaching the anterior margiu; elytra with irregular meshes, divided into series by three strong lougitudinal veins; between the exterior vein and the lateral margin is one row of very small meshes (theso are only visible from a sidoways view), between the central vein and the exterior are two rows, between the central and interior 
three, and between the interior and the suture, one ; beneath and legs testaceous.

L. $1 \frac{1}{2} \mathrm{~mm}$.

In moss, \&c.; Reignte, Ilfracombe; Caterham, Hampstead, Mickleham, Chatham, Champion; Weybridge, Glanvilles Wootton, Dorset, Dale; and Oxshott, Billups.

Dr. Puton has seen an example in which the sutural series of meshes is widened at the apex into two and three series, which he thinks may prove to be tho developed state of this species.

ORTHOSTIRA, Fieb.

$$
\text { (Acalypta, IVestw.) }
$$

Species small, depressed or slightly convex, surface with fine meshes; rarely developed-the developed form of parvula, the only one I am acquainted with, resembles a Monanthia in shape, and quite departs from the short, almost rotundate form of the undeveloped specimens. Head with the vertex bearing two spines, eyes large granulated; antennæ, basal joint very thick, second very short, third very elongate, fourth distinctly thicker than the third; rostral canal open anteriorly, its sides areolated; pronotum with a distinct hood on the centre of the anterior margin, disc with three areolated carinæ, sides reticulated; elytra reticulated, with strongly-raised longitudinal carine.

There are fifteen species given in Puton's Catalogue, of which most are of southern distribution; gracilis, Fieb., however, occurs in Sweden, and may probably jet be found with us. The characters below are from the undeveloped forms of the species.

(2) 1. Pronotum with only a central keel . . BRUNNEA.

(1) 2. Pronotum with three keels.

(4) 3. Margins of the elytra with two rows of

meshes throughout . . . . . CERTINA.

(3) 4. Margins of the elytra with only one row of meshes.

(C) 5. Lateral discal carina touching the hood . Parvola. 
5) 6. Lateral discal carino abbreviated, not touching the hood.

(8) 7. Sntural area with three rows of meslies NIGRTNA.

(7) 8. Sutural area with two rows of meshes . MAcruTuthatMa.

0. brunnea, Gem. (concinna, D. \&. S.).-Pale greyish ochreous, elytra spotted with black. Head black, forehead with two short pale spines, antenniferons processes testaceous, as also the antennar except the terminal joint, which is black; genal lamine very finely areolated; pronotum with the anterior margin produced in the centre into an areolated hood, from the apex of which a strong carina extends to the base of the pronotum, sides rounded, widely reflexed, with three rows of meshes, base produced in an obtuse angle; elytra irregularly spotted with black, sutural area with two rors of meshes, discoidal with about six, lateral with four or five, marginal with two varying to threo at the apex; abdomen dark bromn; legs testaceous.

L. $2 \mathrm{~mm}$.

Rare, in moss, \&e., Scarborough, Willinson; Darenth Wood, Douglas and Scott; Redhill, Surrey, J. Iinnell; New Forest, Ohampion; Church Stretton, Barmouth. Blatch; Armagh, near Cookstown, co. Tyrone, Rev. W. F. Johnson; Horsley, Surrey, Billups; Glanvilles Wootton, Dorset, Dale.

0. cervina, Germ.-Pale testaceous. Head brown, with four pale spines, two being frontal processes, the other two the antenniferous tubercles; anteuna testaceous, apical joint black, genal laminie finely areolated, the rostrum reaching to beyond the posterior coxa, all the sterma bearing strong lamina for its reception; pronotum with three lougitudinal keels, the central one raised in front, and cresting the hood of the anterior margin, lateral margins with three to four rows of meshes, base obtusely angulated; elytra, sutural area with two rows of meshes, discoidal with four, lateral with three to four, marginal with two ; legs testaceous.

L. $2 \frac{1}{\mathrm{~m} m}$. 
Not common, in moss, \&c. Reigate, Knowle, Blatch; Shirley, Caterham, Champion: Fifeshire, Power; Coombe Hurst, Croydon, Douglas and Scott; Glanvilles Wootton, Dorset, and High Bickington, Devon, Dale.

0. parvula, Fall.-The smallest of our species, dull grey or, if immature, more or less testaceons. Head black, with two short paler frontal spines or processes, antenniferous tubercles obtuse, antennæo testaceous, apical joint black, third suddenly enlarged at the extreme base; pronotum with three longitudinal keels, the central one cresting the largely-developed elevated and areolated hood of the anterior margin, sides with two rows of meshes, base produced into an acute angle - the angle longer and more acute in the developed form; elytra, sutural area with one row of meshes at the base, increasing to two, three, four, as it approaches the apex, or expanding in the developed form into a regular finely reticulated membrane, with five to seven rows of meshes across its widest part, discoidal area with five to six rows in the middle, lateral four to five, marginal with one, or just at the base, with two; abdomen brown; legrs testaceous.

L. $1 \frac{1}{t} \mathrm{~mm}$. brach., $2 \frac{1}{\frac{1}{4}} \mathrm{~mm}$. macr.

The macropterous form is quite unlike the brachypterous in shape, and in general appearance resembles a Mtonanthia.

Common and generally distributed, found in moss at tho roots of grass in sandy places, etc.

0. nigrina, Fall-More convex than either of the preceding, grey. Head black, with two short blunt spines on the forehead, antennio with the third joint very slightly and gradually widened towards the base and paler than the others; pronotum with the anterior margin produced and hooded, sides rounded, with two to three rows of meshes, base produced in an obtuso angle, dise with three areolated carinæe, the central one extending to the front margin and cresting the hood, the lateral ones abbreviated; 
elytra with three rows of meshes on the sutural area, four to five on the discoidal, four on the lateral, and one along the margin; legs with the tibice testaceous.

L. $2 \frac{1}{4} \mathrm{~mm}$.

Aviemore, Champion; Morayshire, O. Mr. Reuter.

0. macrophthalma, Fieb.-Very like the preceding, but differing in having the third joint of the antenne parallel-sided throughout, not widened at all at the base, and the elytra with two rows of meshes on the sutural area.

L. $2 \frac{1}{4} \mathrm{~mm}$.

Cheviot, Hardy.

\section{DICTYONOTA, Curt.}

This genus contains somo of our most beantiful species; they may be easily kmown by their thick rugose antenna, the second joint of which is as thick or thicker than the apical. Head with two spinose frontal processes, and the antenniferous tubercles more or less spinosely prodnced, rostral chamnel open in front, its sides largely and distiuctly arcolated; antenno with the third joint rugose, and more or less hairy; pronotum with three keels, lateral margins widely foliaceous, especially in front, and areolated, anterior margin with a central hood, base with a long angular production; elytra flat, with strongly-raised costa, largely reticulated between them. In the of the antemne liave the third joint distinctly longer than in the o. There are fourteen species given by Puton, of which we have only three, but all the others are southern in their distribution.

(2) 1. Third and fourth joints of the antennio with long hairs . . . . CRassicornss.

(1) 2. Third and fourth joints of the antenna without long hairs.

(1.) 3. Second joint of the antennx black and thick STRICINocera.

(3) 4. Second joint of the antemna testaceous, slender IULIGinusa.

D. crassicornis, Full.-Greyish black, head black, with two converging frontal spines, tho autemiferous tubercles 


\section{Tingidida.}

produced into a slightly curved lateral spine, antenna with the third and fourth joints very rugose, and with long erect hairs ; pronotum, disc black, shining, punctured, with three elevated longitudinal carinæ, each when viewed laterally with a row of large meshes, central one terminating in an elevated somewhat globular areolated vesicle, the front margin of which forms the anterior margin of the pronotum; sides very widely transparent and reticulated, especially in front, with three to five rows of meshes; base angularly produced and reticulated; elytra reticulated, greyish, with the nerves black; abdomen black, legs testaceous.

L. $3 \frac{1}{4} \mathrm{~mm}$.

Generally distributed, but not common anywhere; Ireland, IIaliday; not recorded from Scotland.

D. strichnocera, Ficb.-Liko the preceding at first glance, but abundantly distinct in many points. Tho head bears two short flavous carinæ, one just behind each eye on its inner side, the antenniferous tubereles are blunt, and there are two pale frontal spines, not convergent, the third joint of the antenne is much thicker than in crassicomis, but the hairs are adpressed and very short, the apical joint is much thinner than the third; the pronotum is paler in colour in the $q$, being almost white posteriorly, the sides are less widened in front and more rounded, with two to three rows of meshes, the hood of the anterior margin smaller and less globular; the elytra are very similar to those of crassicornis, but the nerves are paler in the of, and the reticulation less regular in both sexes.

L. $3 \frac{1}{2} \mathrm{~mm}$.

On broom and furze, common in many places, and generally distributed, but not recorded from Ireland.

D. fuliginosa, Cost. (Fiel,eri, D. \&. S.).-Larger and paler than either of the preceding, head black, with two white carina near and above the eyes, two pale subparallel frontal spines, and strongly produced but blunt antenniferous processes, antenna testaceous, apex of the terminal joint black, 
third joint very long and slender, compared with those of the preceding species, very rugose and with very short hairs; pronotum with the sides much dilated in front, as in crassicomis, where they have three to four irregular rows of large meshes, posteriorly they have two, base longly produced, reticulated at the apex; elytra rather elongate, the sides slightly sinuate, irregularly reticulated, the nerves testaceous, in places darker; abdomen brown; legs testaceous.

L. $4 \frac{1}{2}-5 \mathrm{~mm}$.

On old broom bushes, Weybridge.

\section{DEREPHYSIA, Spin.}

Integument very thin and membranous, reticulated, the meshes very large. Head punctured; eyes very large; antenniferous processes blunt; antennro slender, finely hairy, and rugose; rostral chamel open in front, its sides finely areolated; pronotum largely reticulated, the central keel terminating in front in a large crested hood, which almost covers the head; lateral margins widely dilated and reticulate; elytra with very large meshes, the discoidal and lateral areas raised to meet the central nerve.

'There are two European species, of which wo have only one.

D. foliacea, Fall.-Nervures of tho meshes pale testaceous, between the nervures the surface is quite shining, transparent, and hyaline, with iridescent reflections; antenuю testaceous, finely rugose, and shortly hairy; apical joint black at the extremity; sides of the pronotum dilated and much raised, with two rows of large meshes behind and three in front; disc with three carina, with a row of meshes in each, the central one the highest; hood with large meshes; nervures more or less finely hairy; elytra very largely meshed, the disc of each raised down the centre; abdomen and legs testaceons.

L. $3 \frac{1}{2}$ mน่. 
This lovely little species is far from rare, and is generally distributed; it occurs in ivy, moss, etc.

\section{MONANTHIA, Lep.}

A genus all of whose species have a sort of common facies, and yet differ in strong structural peculiarities, which have given rise to several well-marked sub-genera, which in some other families would be treated as generically distinct. As characters belonging to the whole genus the following may be given :-

Rostral channel closed in front, i.e. the laminal production of the cheeks beneath are united in front; anterior margin of the pronotum with a more or less distinct hood; pronotum, on its basal half at least, with three keels, its base produced into a long acute angle; elytra with the internal nerve distinctly angulated just at the side of the apex of the base of the pronotum; surface reticulate, or very largely and reticulately punctured.

There are fifty-five species given in Puton's Catalogue, and others have been added since: these are nearly all of southern distribution.

(7) 1. Sides of the pronotum flat and foliaceons, more or less rounded and dilated with rows of clear areolæ (Subg. Platychila, Fieb.).

(6) 2. Lateral margins of pronotum not pilose.

(4) 3. Sides of pronotum with two and three, elytra with three rows of meshes . CARDE.

(3) 4. Sides of pronotum with one row, of elytra with two rows of meshes. . ANGUSTATA.

(3) 5. Sides of pronotum and ely tra with four rows of meshes. . . AMPLIATA.

(2) 6. Lateral margins of pronotum and elytra pilose . . CILIATA.

(1) 7. Sides of the pronotum not dilated and rounded.

(9) 8. Sides of pronotum straight, or slightly sinuate, narrowly reflexed, costate (Subg. Catoplatus, spin.). . . costata, k? 
(8) 9. Sides of pronotum more or less inflated, the intlations reticulate.

(15) 10. Orifice of the odoriferous sac with a distinct channel (Subg.Physatochilu, Fitio.).

(14) 11. Disc of pronotum with three carine, reaching to the hood of the anterior margin.

(13) 12. Elytra with three to four rows of marginal meshes in the middle . .

(12) 13. Elytra with two rows of marginal meshes in front, one posteriorly. . DUMETORUM.

(11) 11. Lateral Hiscal curina abbreviated anteriorly by the lateral intlations.

(10) 15. Sac orifice without a eanal (Subg. Monanthier, Still). . . . HumoL.

\section{(Suвa. PLATYCHILA, Fier.)}

M. ampliata, Fieb. (var. similis, D. \&. S.).-A largo wide species, grey or ochreous grey, more or less mottled with black. Head black, with woolly white pubescence; vertex with threo long pale spines, forehead with two long converging pale spines, terminal joint of the antenne black; pronotum with the anterior margin raised, and hooded in the centre, lateral margins rery widely dilated, especially in front, and raised, with four rows of fine meshes; dise with three not very much elevated carina, the central one only showiug distinct areola at its baso and apex; elytra flat, finely reticulated, with four rows of fine meshes nt the sides; abdomen black-brown, legs ochreous; the depressions of tho upper surfaco in fresh examples are filled with a sort of woolly white pubescence, and the nervures bear very short adpressed hairs, visible only with a strong power.

L. $3 \frac{1}{2}-4 \mathrm{~mm}$.

The var. simitis, $D$. \& $S$., has the pronotal margins less cilated in front.

Not rare; by sweeping, Reigate, Woking, Chobham, Wimbledon, Hayling Island, Hastings; Battle, Barnet, Butlor; Bugbrooke, Northampton, Murshall; Sand-lills, 
Lincolnshire, Mrason; Tilgate, Wicken, Eshor, Chatham, Now Forest, Cowes, Champion; Lee, Chislehurst, Brightbampton Oxon, Donylus and Scott; Cowbridge South Wales, Ely, Billups; Glanvilles Wootton, Dale.

M. ciliata, Fieb. (reticuluta, II. Sch.).-Somervhat of the same wide build as the preceding, and similar in colour; but abundantly distinct from it and all our other species, by the long ciliw of the sides of the pronotum and elytra, antennæ, legs, aud nervures. Ilead black, with a short pale hairy spine above each eye, a central one on the vertex, and one just below it on the forehead; apical joint of the antenne black; pronotum, nnterior margin angularly raised and hooded in the centre, sides much dilated, widest near the middle, with three and a half rows of large meshes; disc with three carine without areole, central one raised in front and cresting the hood; elytra finely reticulate on the disc, the sides with three rows of large meshes; abdomen black; leg's ochreous.

L. $4 \mathrm{~mm}$.

Rare, Monkswood, Huntingdon, Crotch; Scarborough, Lawson; Tilgate, Cobham Park, Champion; Gianvilles Wootton, Dorset, Dale.

Dr. Puton gives its habitat as in the flowers of Ajuga reptans.

M. cardui, Limn-Greyish, with darker mottlings. Head black, with silvery downy pubescence, with a tubercular spine on the vertex, and two converging frontal spines, pale; second and third joints of the antonuæ pale ; pronotum, anterior margin raised and hooded, projecting slightly over the head, sides rounded posteriorly, reflexed, with three rows of meshes posteriorly and two anteriorly; the nerves black in places; dise with three strong areolated carino, the central one cresting the hood, the lateral ones interrupted by it; elytra flat, finely reticulated, the nerves in places black; lateral margins with three rows of meshes; the dark mottlings of the elytra form a more or less definite 
band across their centre; abdomen black; legs with the femora black at the base.

L. $3{ }_{4}^{1} \mathrm{~mm}$.

Very common on thistles, and generally distributed.

M. angustata, H. Schfi--Paler and narrower than the preceding, to which it is closely allied, but from which it may be known at once by tho narrow marginal reflection of the pronotum, which has only one row of meshes, and the less elevated discal carina, the lateral ones of which show no areolas; the margins of the elytra also are narrower, with only two rows of meshes, and there is scarcely any darker mottling on the nerves; but this may vary, as I have seen very few continental examples, and have only the one British specimen; all I have seen, however, agree in coloration.

[. $3 \mathrm{~mm}$.

One specimen by sweeping, near Cisbury, Worthing.

\section{(Soвa. Catoplatus, Spin.)}

M. costata, Fieb.-A species very distiuct by the narrow, sinuate margins of the pronotum. Pale testaccous; head brown, with two convergent frontal spines, and a small one adpressed to the surface above them; antenniferous tubercles angularly produced, apical joint of the antenna dark; pronotum with the anterior margin very short, raised into a slightly elevated hood, sides nearly straight or slightly sinuate, narrowly reflexed, with one row of small meshes; disc with three longitudinal carinæ, the central one cresting the hood; elytra much wider than the pronotum, with fine meshes, sides rounded, with three rows of meshes; abdomen black.

L. $3 \frac{1}{2}-4 \frac{1}{2} \mathrm{~mm}$.

Reigate; Tunbridge Wells, Caterham, Chattenden, Champion; Folkestone, Riye; Berwdley, Trench Woods, Cannock Chase, Blatch; Langport, Somerset, Dale; Bushey, Herts, Pourer; Headley Lane, Margate, Deal, 
Taff's Well South Wales, Billups; Glanvilles Wootton, Dorset, Dale.

(Soba. PHYSATOCHILA, Fiez.)

M. quadrimaculata, Wolij.-Dark brown $\delta$, or pale chocolate-brown $q$; sides of the elytra with a white spot at the base and near the apex. Head black, a curved adpressed spine lying along the inner margin of each eye, a short central one on the vertex, and two converging frontal spines, pale; antennx slender, ferruginous, apical joint black; pronotum with a rather high hood on the anterior margin, sides nearly straight, lateral inflation narrow, parallel-sided, with three rows of honeycomb-like cells or meshes; disc with fine meshes and three longitudinal carine; these do not exhibit any clear areoli, central carina cresting the hood; elytra flat, finely meshed, sides rounded in front, subsinuate posteriorly, with three to four rows of irregular small meshes in the central dark portion, and with two rows of large clear meshes in the basal and subapical clear spots; abdomen brown; legs ferruginous.

L. $3-3 \frac{1}{2} \mathrm{~mm}$.

On old apple-trees; Ewhurst, E. A. Butler; Brockenhurst, Douflas; New Horest, Fouler; Glanvilles Wootton, Dale; Weston-super-Mare, Billups; Oreston, Bignell.

M. dumetorum, $H$. Schfi.-Very like the preceding, but smaller and narrower: the lateral inflations of the pronotum with only two rows of cells or meshes; elytra with the margins narrow, with two rows of small meshes at the sides in front, as well on the dark as on the clear portions, and one row of larger meshes behind.

L. $2-2 \frac{1}{4} \mathrm{~mm}$.

On old whitethorns; Chobham; Esher, Ashtead, Darentl, New Forest, Champion; Norfolk, Eilwards; Redgrave Fen, Blatch; Well Vale, Lincolushire, J.E. Mason; Glanvilles Wootton, Dale; Lee, Kont, Southampton Common abuudant, Douglus; Woking, Oxshott, Cardiff, Billups. 
M. simplez, II. Schff--Somerhat convex, ferruginous, head and abdomen and thoracic segments benenth black. Head with an adpressed spine lying along the inner margin of each eye, a spine on the vertex, and two converging frontal spines ferruginous; antenne with the apex of the terminal joint black; pronotum with the anterior margin hooded, sides with largo inflations, their inner margins rounded, and almost meeting in the centre, just leaving room for the central carina to run between them, but interrupting the lateral ones; elytra subconvex, with fine ccllular meshes throughout, the lateral margin with a single narrow row of fine clear meshes; legs ferruginous.

L. $3 \mathrm{~mm}$.

Rare; Redhill, Surrey, J. Linnell; Folkestone, Darenth, Chatham, New Forest, Champion; Islo of Wight, Power; Bexley, Kent, Sicott; Bickleigh Woods, Bignell.

(Subg. MIONANTHIA, Stäl.)

M. humuli, Fub.-Greyish ochreous. Head black, punctured, with two very short pale convergent frontal spines; antenniferous tuborcles obtuse; pronotum with the anterior margin hardly raised or produced in the middle, and therefore forming a very feeble hood, sides with large wide inflations, bearing four rows of cell-like meshes, their inner margins emarginate and subparallel to the lateral margins; dise reticulated, with three longitudinal carina, the central one entire, with its basal apex black, and the lateral ones interrupted by the intlations; elytra finely reticulated, flat, lateral margins with two rows of meshes at the base, one in the centre, two in the subapical sinuation, and one at the apex; nerves of the elytra with a distinct black spot at the apex of the discoidal area, and another on the central nerve, near its centre; many of the lateral reticulations are also black; abdornen black; legs ochreous.

L. $+\mathrm{mm}$. 
On Myosotis, etc., in damp and swampy localities, and margins of ponds; Woking, Ilfracombe ; Norfolk, Edwards; Coleshill, Sutton Park, Blatch; Hastings district, Shalford, Butler; Tilgate, Wimbledon, New Forest, Champion; Cowbridge, South Wales, Billups; Glanvilles Wootton, Dale; Perth, B. White.

\section{ARADID压.}

A family of few genera, of which we have only tro in this country, which occur under bark, in fungoid growths, etc. It is allied to the Tingididie in many respects, but differs from it in the general form, the large scutellum, the position of the anterior coxx, which are inserted in the disc of the prosternum and not at its base, and the absence of reticulation or cell-like puncturation; the antenniferous tubercles are large and angular, or spine-like, the cheeks are very short, and the central lobe of the face forms an elongate blunt process; ocelli absent; the antennæ are short and rugose, and the rostrum variable in length, very short in Aneurus; the pronotum transverse; the elytra produced and rounded at the shoulders; tarsi two-jointed.

(2) 1. Flat, prouotum with longitudinal keels, scu.

(1) 2. Very flat, pronotum without keels, scutellum rounded.

Aradus.

- Anedros.

\section{ARADUS, $F a b$.}

Flat, surface finely rugose; eyes prominent, head contracted behind them; antenniferous tubercles spine-like; antennæ thick, joints truncate at the apex; rostrum longer than the head; sides of the pronotum in our British species reflexed, foliaceous, and more or less ragged; the scutellum is long, with its sides raised; the elytra are dilated at the base, the sides converging in sinuate lines so as to leave the connexivum uncovered; the apical margin of the corium is more or less angularly emarginate; the membrane is large, reaching almost to the apex of the abdomon; the connexivum 
is dilated, wide, and foliaceons; legs small and thin; beneath, all the segments of the thorax have a uarrow central channel, the abdominal segments all more or less shortened and emarginate in the middle of the posterior margin; the fifth strongly emarginate, raised in the centre, sixth with its centre apparently hidden under the fifth in the $f$; three genital segments visible in the $f$, one in the $\delta$.

There are a great number of European species in this genus. Puton gives as many as fifty-four as palæarctic in his Catalogue, but we have only four recorded from this country.

(6) 1. Not entirely black.

(3) 2. Second joint of the antenno longer than the third and fourth together . . . corTICALIs.

(2) 3. Second joint of the antenna not nearly so long as the third and fourth together.

(5) 4. Lateral margins of the pronotum broadly white in front.

(4) 5. Lateral margins of the pronotum dark

thronghout . * . . . LAWSONI.

A. corticalis, Limn.-Brown, finely and granulately rugose; central lobe of the face very long; antenniferous tubercles long and acute; antennos with the secoud joint longer than the third and fourth together, third pale at the apex, fourth silver-haired at the apex; pronotum with the anterior angles not produced, lateral margins jagged, narrowly reflexed, and diverging rapidly in front, largely rounded, reflexed, and dilated posteriorly, base deeply sinuate across the scutellum, disc with four longitudinal ridges and a longitudinal tubercle near each posterior angle; scutellum with its margins raised; elytra pale and dilated at the base, then narrowed, so as to show the apex of the first abdominal segment, their nerves strongly raised; the posterior margin of the corium with a rectangular notch just below the scutellum; membrane smoky brown; 


\section{Aradida.}

comnexivum with paler lines at the apices of the segments; legs brown; apices of the femora slightly paler.

L. 7-8 $\mathrm{mm}$.

Rare; under bark, otc., New Forest; West Wickham, Kent, Douglas and Scott; Parley Heath, Dale.

A. Lawsoni, Saund.-Like the preceding in colour, but rather shortor; the antenniferous tubercles rather less divergent and sharp; antenna with the third joint ontirely dark, subequal in length to the second; anterior angles of the pronotum slightly produced forwards, lateral margins broadly reflexed throughout, very slightly jagged, base very slightly sinuate across the scutellum; scutellum narrower than in corticalis, with its sides more strongly raised, its disc transversely rugose; elytra much dilated at the base, the dilatation much larger than in corticalis, mottled with pale ochreous, and covering the basal segment of the abdomen entirely and half of the second; membrane more widely rounded at the apex; notch in the apical margin of the corium less distinct, and fartler from the apex of the scutellum; terminal segment of the abdomen with a bilobate white spot; abdomen brown beneath; legs pale ochreous, the femora at the base and a band across each tibia darker.

L. $7 \mathrm{~mm}$.

One specimen, without locality, from Mr. Larson's collection.

A. depressus, Fab.-Differs from either of the preceding by the pale spot at the anterior angles of the pronotum and the testaceous red or pale brown abdomen. Head brown; antennæ shorter than in either of tho preceding, with the third joint a tritle shorter than the second, fourth joint with silvery hairs at the apex; pronotum with the anterior angles produced; lateral margins widely reflexed, and jagged; base nearly straight; disc brown, with four keels as in the other species; the reflexed lateral margius anteriorly, for about half their length, white; 
scutellum brown; elytra whitish, dilated at the base, the dilatation covering tho first and two-thirds of the second abdominal segments; nerves brown towards the apex; membrano smoky white at the base, and more or less reticulated with white throughout; abdomen red-brown, with a whitish spot at the base of each segment of the connexivum; legs pale ochreous.

L. $5-6 \mathrm{~mm}$.

Not rare; under bark, on old stumps, ctc.; Reigate, Coombe Wood, Woking, Bromley; Darenth Wood, Packwood Park, Warwickshire, Aberguvenny, Marshall; Salford Priors, Malvern, Tonbridge, New Forest, Blatch; TVell Vale, Lincolnshire, J. E. Muson; Hastings, Guestling, Battle, Butler; Chathum, Sevenoaks, Loughton, Caterham; Champion; Cardiff, Billups; Glanvilles Wootton, Dorchester, Dale.

A. aterrimus, $D . \&$ S.-Deep black. Head with the antenniferous tubercles acute, the points turned slightly inwards; antenne thin, second joint not quite so long as the third and fourth together, third three-quarters the length of the second, fourth half the length of tho third; pronotum with the side margins narrow, but rounded at the anterior angles, widening posteriorly, simuate in front of the posterior angles; posterior margin slightly sinuate; disc with four keels, and an oblong tubercle near each posterior angle; scutellum long, narrow, side margins much xaised, apex obtuse; elytra not much dilated at the base, with strongly raised nerves; connexivum with a yellow angular spot at the posterior angle of each segment; legs, lemora black, tibie and tarsi rather paler.

L. $6 \mathrm{~mm}$.

One of specimen, "Darentll Wood, among chips on the stump of a felled oak, 30th May, 1861, Douglas; another, ठ, from Mr.J.H. Harding's collection, without note of its locality," Douglas and Scott. 


\section{ANEURUS, Cwrt.}

Very flat, comparatively smooth. Ilead with a narrow neck, then suddenly widened to a width not quito equal to the anterior margin of the pronotum, angulated behind the eyes; eyes slightly prominent; antenniferous tubercles rectangular; central lobe of the fice elongate, rounded and narrowed in front; antenne with the joints more or less rounded at the apex; pronotum widely transverse; scutellum large, and rounded posteriorly; elytra almost entirely membranous, the corium and clavis being scarcely definable, and indicated only by a very short coriaceous basal portion; apex of the membrane broadly and truncately rounded; wings short; connexivum wide and flat; genital segments in the male projecting beyond the apex of the connexivum, in the $q$ two visible from above; legs short, femora slightly incrassated.

A very curious genus, of which we possess the only European species. It occurs under bark, and is the flattest species found in this country.

A. lævis, Fub.-Pitchy brown; antennæ, legs, and abdomen rather paler. Head wrinkled transversely on the vertex; antennæe with the first joint oral, the second about equalling it in length, but thinner, the third about once and a half as long as the second, the fourth about once and a half the length of the third; pronotum with the anterior margin sinuate, the dise deeply and transversely impressed, base nearly straight; scutellum transversely wrinkled, semicircular; membrane lying closely adpressed to the abdomen, smoky brown; connexivum widely extended beyond the membrano on each side, dull; the abdomen beneath the membrane with a very shining line down each side and down the centre.

L. $5 \mathrm{~mm}$.

Reigate, Bromley; Fnirlight, Butler; Bath, Blathwayt; Bridgenorth and Darenth Wood, Marshall; Bewdley 
Forest, Blatch; Caterham, Chatham, Champion; Choblam, Orshott, Weybridge, and Mickleham, Billups.

\section{HEBRID $₫$.}

The position of this little family has always been a matter of some doubt, but its relation to the Hydrometridre seems to me to be the closest; and as Dr. Puton in his Catalogue places it in front of that family, I have adopted the position Iro assigns to it. In habits the family may be called subaquatic, as its members are found amongst Lemna, in marshes, and in Spaghnum, etc., and are clothed beneath with tho fine silvery, silky pubescence observable on the undersides of Gerris, etc., which appears to be impervious to water. In form short. Head with the face declivous; eyes large, round, with very large facets; ocelli small, situated between them; face wide; the antenniferous tubercles situated far in front of the eyes, and rather low down on the side of the head, largely developed, rounded; antenna five-jointed; the sixth joint, mentioned by Messrs. Douglas and Scott, appears to me to bo only the extreme, narrow, base of the third; rostrum four-jointed, received into a canal under the head and thorax; pronotum trapezoidal; scutellum triangular; elytra with the clavus submembranous; membrane without nerves; corre widely separated, especially the posterior pair; tarsi two-jointed, claws at the aper of the tarsi; two genital segments visible in the $\sigma$, three in the $q$.

\section{HEBRUS, Curt.}

As there is only one genus in the family the characters given above will be sufficient to identify it.

1. Basal joint of antenne projecting for half its length beyond the apex of the head : . Pusilues.

2. Basal joint of antennae scarcely projecting beyond the apex of the head.

RUPICEYS.

H. pusillus, Fall.-Short, blackish brown. Head rather remotely punctured, with a whitish tinge along the inner 
sides of the eyes, centre slightly impressed; antenna testaceous, finely pilose, first joint as long as the third, slightly curved, extending for more than half its length beyond the apex of the head, second about two-thirds as long as the first, fourth about as long as the second, fifth rather longer; pronotum black or brown, punctured, much widened posteriorly, slightly constricted before the middle, with a wide central channel in front, and a small forea on each side; posterior angles rounded, base slightly produced and rounded; scutellum black; elytra with the clavus submembranous, white at the base, corium brown, clothed with very short golden hairs; membrane very large, smoky, with a white spot on each side, and a longitudinal median streak near the apex; connexivum slightly reflexed; legs testaceous, posterior femora slightly curved.

L. $1 \frac{1}{3} \mathrm{~mm}$.

On Lemna, in Sphagnum, etc., Plumstead; Isle of Wight, Lewis; Southgate, $F$. Walker; New Forest, Birmingham, Blatch; common in very wet moss, Norfolk, Edwards; Portland, Dale; Canning 'Town, Rainham, Essex, Billups.

H. ruficeps, Thoms-Dimorphous, and differing from the precediog in having the basal joint of the antenno much shorter, scarcely projecting beyond the apex of the head, in the paler reddish head and pronotum, the unspotted membrune, and the undefined basal spot on the base of the clavus. In the only developed specimen before me, from Mr. Billups' collection, the whole clavus is white, and the corium has a pale central line. In the undeveloped form the pronotum is less widened posteriorly, and the elytra are reduced to two small straight lobes, with a small membranous dilatation on their inner margins, hardly longer than the scutellum.

L. $1 \frac{1}{2} \mathrm{~mm}$.

In Sphagnum, Chobham; in swarms in Sphagnum, Loughton, Essex, October, 1884, one specimen developed, Billups; Perth, O.M. Tieuter; Cannock Clase, Blatch. 


\section{HYDROMETRID FE。}

This family is composed of various genera, some of which seem to me to have very little in common; the may, however, all be said to be subaquatic. Aepoplitus is perhaps the most aberrant, its contiguous coxa and Iyggaid antennæ giving it an aspect quite foreign to the other members of the family. Alesoveliu, again, has almost contiguous coxio, but the antenur are very different from those of Aëpoptitus. The extrwordinarily produced face of Hydrometra is utterly unlike that of any other of oul genera; they, however, have a few features in common; they all have the elytra of one texture throughout, and undivided into corium, clavus, and mombrane, and tho underside clothed with white silvery pubescence, which is no doubt impervious to water, and are destitute of odoriferous sacs. The habits of Aëpophilus and Mesovelia are at present very little known; the former is a submarine species, occurring under stones, etc, below high-water mark. Mesovelia, according to Sahlberg, occurs on the leaves of $N y m p h a d$ Potumogetun, etc. The other genera of the family live on the surface of the water. 'The members of this family are carnivorous.

\section{TABLE OF SUBFAMILIES.}

(4) 1. Coxæ contiguous or nearly so, scutellum visible.

(3) 2. Ocelli absent

Aërophilina.

(2) 3. Ocelli well developed . . . Mesovelina.

(1) 4. Coxa widely separated, scutellum covered.

(6) 5 . Head very elongate in front of the eyes, many times longer thon wide, and widened towards the apex... . .

(5) 6. Head short, as wide across the eyes as long.

(8) 7. Posterior femora not reaching to the apex of the abclomen.

(7) 8. Posterior femora very long and thin, reach-
ing far beyond the apes of the abdomen. HYDRONETRINA.

Velina.

Gernidina. 


\section{AËPOPHILINA.}

\section{Ä̈POPHILUS, sign.}

Short, suboval, finely pubescent. Head convex, eyes touching the pronotum, ocelli wanting, antenniferous tubercles on the underside of the choeks; antenna long and thick, four-jointed, the joints, except the basal one, which is slightly thickened, of about equal width; rostrum four-jointed, extending to about the intermediate coxæ, its apex very finely pointed; pronotum transverse, its sides and anterior margin straight, base slightly sinuate; scutellum short and wide; elytra undeveloped, very short at the suture, their lateral margin rounded, about twice as long as the sutural, apical margin sinuate, apical lateral angle acute. Dr. Puton remarks that the of has the genital segment exposed above, the of beneath. The specimens I have before mo appear to be males; legs pubescent, tarsi three-jointed, claws at the apex of the tarsi, very strong and curved.

A. Bonnairei, Sign.-Ferruginous, finely pubescent, with a few longer fine hairs, elytra and abdomen darker. Head rather shining; eyes round, red, not projecting beyond the pronotal angles; anteuna with the basal joint slightly produced beyond the apex of the head, second thinner than the first, and about twice its length, third and fourth subequal in length, slightly shorter than the second; pronotum transverse, front margin and sides straight and parallel, base slightly sinuate, lateral margins narrowly reflexed; scutellum very wide and short; elytra short, shaped as described under the head of the genus; abdomen with all the segments exposed, its sides rounded, and the connexivum much reflexed. I'wo genital segments at least appear to me to be visible, but they are very curious in form, and I cannot satisfy myself as to their exact relations to each other; legs rather thick.

L. $3-3 \frac{1}{2} \mathrm{~mm}$. 
Under stones, etc., below high-water mark; Polperro, Cornwall, F. Smith; Mousehold, near Penzance, under stones and under a star-fish, Murquand; Lyme Regis, W. K. Kilbonme; Plymouth, J. I. K.ys. Mr. Keys made some interestiug obscrvations on a specimen which he had in confinement for some days; he found that it would not live nnder water, and when placed on the surface attempted 110 movement of its own; he gave it a piece of a submarine worm, and says he "had the satisfaction of observing the bug in close proximity, rubbing or cleansing its proboscis with great gusto, suggesting the idea that it had just enjoyed its morning meal."

\section{MESOVELIINA.}

MESOVELIA, Muls. \& Rey.

Dimorphous, elongate. Head with the eyes large, almost touching the promotum; ocelli on the vertex; face elongate; antenniferous tubercles largely daveloped, situated rather on the underside of the head; antenno slender, first joint long and slightly curved, about equal to the third in length, sccond slightly shorter, fourth about equal to the third; rostrum reaching to the intermediate coxe; pronotum subtrapezoidal, the posterior angles bluntly produced, the base sinuate; scutellum large, produced aud somewhat square at the apex; elytra with the corium coriaceous and strongly nerved; clavus submembranous; membrane wanting in the brachypterons form; abdomen with two long genital segments in the $\delta$, visible above, one short one in the $q$; legs long and slender; coxre contiguous, or nearly so; tarsi three-jointed; claws apical.

There is only one known European species of the genus.

M. furcata, MIuls. \& Fiey.-Elongate. Head testaceous, with the central lobe of the face, a line on the forehead, ind two round spots on cach side black; pronotum tes- 
taceous in front, black behind; sides slightly sinuate; posterior angles rounded and produced; base slightly sinuate; disc with two small forea anteriorly; scutellum black, more or less pale in the centre; elytra with the nerves of the corium very strong, pale between them; clavus membranous, white; membrane, when present, white, and without nerves; legs testaceous ; abdomen pale, beneath clothed with dense white pubescence.

L. $3 \frac{1}{2} \mathrm{~mm}$.

Burton-on-Trent, Woking Canal; rare.

\section{HYDRONETRINA.}

\section{HYDROMETRA, Lat?.}

This genus is so peculiar in form that it cannot be confounded with any other; its babit also of walking slowly along the surface of the water is, I believe, peculiar to itself. There is only, so far as I know, one Palacarctic species.

Very elongate linear. Head very long, longer than the entire thorax, widest in front, at the antenniferous tubercles; eyes far remote from the pronotum; ocelli absent; face horizontal; antennw slender, inserted near the apex of the head, first joint reaching slightly beyond the apex of the head; rostrum three-jointed, scarcely as long as the head; pronotum nearly parallel-sided, more than twice as long as wide; scutellum hidden; elytra in developed specimens in one piece, nearly as long as the abdomen, in undeveloped specimens short and subtruncate; abdomen nearly parallelsided; genital segments long in the $\delta$, two visible above, the first produced above over the second in a point, beneatl with two small tubercles; apical abdominal segment also with two raised ridge-like tubercles; o with the genital segments shorter, but with the projecting point of the first segment longer, reaching beyond the apex of the second; 
legs long and slender; coxa very remote, inserted at the sides of the sterum; claws apical.

H. stagnorum, Linn.-Linear, black; pronotum and base of the head, and of the first and second antennal joints more or less rufescent; legs testaceous, apices of the femora and tibic and the tarsi darker; surface dull; antenniferous tubercles shining, second joint of the antennæ thinner than the first, about twice its length, third about three and a half times as long as the second, fourth longer than the second. Head between the antenna wider than across the eyes; pronotum slightly strangulated in the middle, its sides simuate posteriorly when viewed laterally; disc with a central impressed line; elytra, when developed, with two small discal tubercles, and pale between the nerves; beneath clothed with fine silvery pubescence.

L. 11-12 mm.

Generally distributed, on stagnant water.

\section{VELIINA.}

Elongate, $6-7 \mathrm{~mm}$. in length, first joint of antennx long, curved . VELIA. Short and broad, $1 \frac{1}{2}-1 \frac{i}{2} \mathrm{~mm}$. in length, first joint of antennæ short .

- Microvelia.

\section{VELIA, Latr.}

A genus of only two or three species as far as Europe is concerned, which live on the surface of running water, although they have been found occasionally on stagnant. The Rev. W. F. Johnson reports the capture of our British species, $V$ currens, on stagnant water in Ireland, at a great distance from any stream; the species are dimorphous, the winged form of curme being much rarer than the apterous. Head short; eyes large, not quite touching the pronotum; ocelli wauting; face short, nearly perpendicular; intenniferous tubercles rounded: antennit with the first 
joint the longest, and curved, the other three about of equal length; rostrum reaching to about the middle of the mesosternum; pronotum five-sided in the developed form, much widened behind; base largely produced over the base of the elytra, subtrapezoidal in the undeveloped; elytra in the developed form without divisions, entirely membranous, in the undeveloped entirely absent; connexivum reflexed, the sixth segment produced into a sharp point; in the $\delta$ two genital segments are visible above, in the of only one; on the first abdominal segment in the developed form are two sharp longitudinal ridges, springing from a semi-circular basal elevation, which looks like a scutellum, but is really abdominal; legs inserted at the sides of the sterna, so that the coxæ are very remote; intermediate femora very long, narrow; posterior femora incrassated, bearing two spines and a row of denticulations in the $\delta$; tarsi three-jointed; claws subapical; metasternum with a curved carina, terminating in a transverse impression above the posterior coxæ, and from its posterior side project several curved bristly hairs; this resembles the orifice of the odoriferous sac in the land bugs.

V. currens, Fab.-Blackish brown. Head with a smooth vertical line; pronotum largely and shallowly punctured, front margin and dorsal line more or less testaceous, near each anterior angle is a round silvery pubescent spot; sides slightly sinuate; base subtruncate in the undeveloped form, produced into a long angular process in the developed, its apex widely rounded; elytra. when present, black, with two busal spots, an oval spot ou the middle of the disc, and a small round apical spot white; abdcmen testaceous, with the angles of the segurents of the connexivum, and a spot on each side of the segments beneath, black; in the undeveloped form there is a broad black band on each side of the abdomen; genital segments black; legs black, femora slightly paler towards the base, posterior pair incrassated, especially in the male, in which 
sex they bear two spines on their underside, and a row of denticulations.

L. 6-7 $\mathrm{mm}$.

Common in streams, etc.; developed form rare; it appears to be generally distributed, as it is recorded from Armagh, Johnson; Connemara and Aran Island, R. F. Scharti; Forres, Norman; Shetlands, Reuter.

\section{MICROVELIA, West.}

Very small, short. Head triangular; face slightly declivous; eyes very large, touching the pronotum, and projecting beyond its anterior angles; ocelli absent; antenniferous tubercles on the underside of the head, first joint of the antenne thick, not projecting more than a quarter of its length beyond the apex of the face, second joint at the aper about as thick 'as the first, third joint thinner, about equalling the second in length, fourth joint long, about equalling the second and third together, and in the centre about as thick as the first; rostrum renching to the middle of the mesosternum; pronotum with its sides short, base angularly produced over the elytra in the developed form, very slightly and evenly rounded in the uncteveloped; elytra in the developed form submembranous thronghout, rather longer than the abdomen; nerves thick; abdomen beneath clothed with silvery hairs; connexivum reflexed; legs, coxæ very remote from each other, intermediate femora long and narrow, posterior pair incrassated, tarsi of front legs two-jointed, of the others three; claws iuserted above the apex of the terminal joint.

M. pygmæa, Duf.-Black. Head with a silvery line along the inner margin of each eye; first joint of the antenna pale at the base; pronotum with the posterior angles produced considerably beyond the sides of the clytra; near the auterior margin are two small transerse 
pale spots, which, with the margin, are clothed with shining silvery pubescence; disc with an elevated dorsal line; elytra greyish black, with numerous elongate white patches, and a round one behind the centre of the lateral margin; abdomen black, with silvery patches of hair above, and clothed beneath with silvery hairs; legs black, femora pale at the base.

L. 1-1 $\mathrm{mm}$.

Macropterous form rare; near Chobham; Reigate; Lincolnshire, J.E. Muson; Norfolk, "common," Elwurds ; Cardiff and Taff's Well, Billups; Pett Level, Sussex, Butler; Hayling, Lulworth, Edinburgh, Belfast, Dule.

\section{GERRIDINA.}

\section{GERRIS, $F^{\top} a b$.}

$\Lambda$ genus distinguishable at once by is long thin legs, and its habit of jumping along the surface of the water.

Species often dimorphous, elongate, upper surface dull, more or less black, in some species with the pronotum brownish, beneath densely clothed with brilliant silvery hairs. Head short; face horizontal, parallel-sided in frout of the eyes; eyes very large and prominent; ocelli none; antenniferous tubercles small, but slightly prominent; antennæ with the first joint very loug; rostrum short; first and second joints short and thick, fourth joint thin; pronotum elongate, constricted anteriorly, its base produced into a somewhat rounded angular process; elytra, wheu present, hard, coriacoous, strongly ribbed; connexivum sometimes produced at the apex into an acute process, at other times into a rounded angle; three genital segments visible in the $\delta$, two in the $q$; anterior cosw very distant from the intermediate pair; intermediate and posterior pairs close together, situated on the sides of the sterna; 
intermediate and posterior femora very long, also the tibia; theso vary much in proportions in the different species; tarsi two-jointed; claws ante-apical.

We have ton species in this country out of twelve recorded as Palrearctic in Puton's Catalogue. 'They are all very much alike in general shape and colour, but there are good structural characters in the legrs, antennæ, etc., by which they may be distinguished apart.

(6) 1. Sixth segment of the abdomen produced at each side into a more or less elongate spine.

(3) 2. More or less ferruginous, first joint of the antenne shorter thim the second and third together (Subg. Limnoporus, Stal.) (.)

(2) 3. Black, first joint of the antenna longer than the second and third together (Subg. Hygrotrechus, Stal-).

(5) 4. Points of the six th abdomiual segment projecting as far as or beyond the geuital segments, lateral margins of the pronotum narrowly palo.

(4) 5. Points of the sixth ablominal segment
shorter than the genital segments, promotal wargins conculorous.

(1) 6. Sides of the sisth segment of the abdomen not spinose, only angular (Subr, Limnotrechus, Stal.).

(12) 7. Pronotum more or less yellowish on the disc.

(11) 8. Audomen beneath finely carinated, without longitudinal lines in the silvery pubescence.

(10) 9. Larger and more robust, pale colour more rufescent, very wide across the

(3) 10. Smaller and less robust, iale colour the intermediate coxas

(8) 11. Abumen beneath finely channelled down the centre, and also with lougitudinal lines in the silvery pube-

(6) 12. Pronotum entirely hack on the disc.

(14) 13. Lateral margin of the pronotum yellow only behind the anterior constric. tion 
(13) 14. Laternl margin of the pronotum yellow also anteriorly.

(18) 15. Posterior tibin and tarsi together almost as long as the femora.

(17) 16. Male with two teeth on the sixth segment beneath, female with the first genital segment transverse, and trausversely impressed.

(16) 17. Male without teeth on the sixth seg. ment, female with the first genital segment square, and carinated longitudinally ${ }^{\circ}$ osterior tibie and tarsi together

(15) 18. Posterior tibix and tarsi together
about two-thirds as long as the femora . ARGENTATA.

G. rufoscutellata, Latr--Rufescent or ferruginous; head, a spot on each side of the pronotum in front, the mesopleuræ just under the pronotal plate, the elytral nerves and the abdomen abuve blackish brown, beneath densely clothed with silvery shining hairs. Antennw very long, when turned backwards reaching to the posterior cosæ, first joint not quite so long as the second and third together, second and fourth subequal, third rather shorter; pronotum elongate, very slightly widened behind, base produced in a rounded angle ovor the elytra, dise with a distinct, slightly raised, paler dorsal line, and with a blackish spot on each side of it near the anterior margin, surface clothed with exceedingly short golden hairs, visible only under a strong power; elytra slightly longer than the head and pronotum together, rufescent, nerves thick, darker, and clothed as the pronotum; abdomen black above; connexivum marrowly pale, produced at the apex into a long spine, about equalling the genital segments in length in the $\delta$, or longer than these in the $q$; legs ferruginous, apical joint of the posterior tarsi not a quarter so long as the basal.

L. $17 \mathrm{~mm}$.

Very rare; Mousehold Heath, Drayton Drewray, Horning, Etlwards; Guestling, near Hastings, L. I' 
Collett; Pitlochry, Norman; Haliday Collection without locality.

G. paludum, Fub.-Like the preceding in form, nniformly black, with the exception of the lateral margins of the pronotun, a dorsal line on its anterior lobe, a transverse spot at the base of the head, and the connexivum, which are pale. Antennx shorter than in the preceding, its first joint very long, nearly as long as the other three together; surface of head and pronotum densely clothed with exceedingly short golden hairs, which impart a brownish tinge to them; elytra entirely black; abdomen black above; connexivum narrowly pale, its posterior spines dark, longer than the genital segments, slightly bent outwards at the apex; legs with the posterior femora distinctly longer than the tibia and tarsi together; apical joint of tarsi not half so long as the basal. Almost always macropterous; I have never seen it otherwise.

L. $16 \mathrm{~mm}$.

Chobham; Caterham; Eltham; Battle, Butler; Cardiff, Taff's Well, Cowbridge, Billups; Aylesford, Marshall.

G. najas, De G.-Very like paludum, but very rarely winged; it diflers however from that species in having no pale streal on the pronotal margin, the first joint of the antenna as long as the rumaining three, the posterior femora only just longer than the tibia and tarsi together, the first joint of the tarsi not quite trvice as long as the second, and the connexival spines not so long as the genital segments, straight, their extreme apices not divergent.

L. $16 \mathrm{~mm}$.

Streams, Reigate, Chobham; Hastings, Butler; Devon, Parfitt; River Avon, Nunton, Marshall; Glanvilles Woottou, New Forest, Dale; Yelvertou, Bignell.

G. Costæ, H. Scliff.-Shorter and broader than any of the preceding. Head black, antenna ferruginous, basal joint about equal to the second and third together, second and third subequal, fourth slightly shorter than the first; 
pronotum considerably widened posteriorly, its dise widely rufescent on the posterior lobe with a darker dorsal line, anterior lobe dark, with a rufescent dorsal line, sides below the lateral carine fulvous; elytra black; abdomen black, connexivum pale, its extreme edge darker, its apex terminating in an acute but not sharply-pointed angle, which reaches to about the apex of the first genital segment; legs ferruginous, anterior femora outwardly black; mesopleuræe very wide, projecting far beyond the sides of the pronotum, especially at the region of the intermediate cosw, clothed with greyish silvery pubescence next the pronotum, then with a band of golden pubescence below that, the underside of the sterna silvery; abdomen beneath with a fine central carina and a very shallow depression along each side of it, sixth ventral segment in the of deeply and bisinuately emarginate.

L. $13 \mathrm{~mm}$.

A subalpine species; Ox Edge, Buxton, W. W. Fouler; Loch Rannoch, Marshall; Perthshire, MIcLachlan; North Wales, H. Francis; Pitlochry, Norman; Orkneys and Aberdeen, Reuter; Ben Nevis, Isle of Harris, Dale.

G. thoracica, Schum.-A much slenderer species than the last, though like it in the distribution of colour; the rufescent colour is, however, paler and of a yellower tinge, and the dark ground colour of the insect is rather paler and more greenish brown; eyes more prominent; pronotum less widened behind, the pale submarginal band not continued on to the anterior lobe; legs with the first joint of the posterior tarsi nearly twice as long as the second; the mesoplenre are much less produced laterally than in Coste, and the abdomen is not impressed longitudinally at the sides of the central carina; sixth ventral segment in the male deeply and bisinuately emarginate.

L. 11-12 mm.

Common, and generally distributed.

G. aspera, Ficb.-Rather shorter than thoracica, and 
coloured more like Costa. Dorsal and submarginal lines of the pronotum pale throughont; elytra, when present, of a rufescent brown; connexirum rather more narrowly pale; femora shorter than in thordecict, the basal joint of the posterior tarsi not nearly twice as long as the second; abdomen beneath with a fine central channel, and also with the silvery pubescence on each side arranged somewhat in longitudinal lines; sixth ventral segment in the of simply emarginate.

L. $10-11 \mathrm{~mm}$.

Rare, and apparently a northern species; Loch Galby, Power; Pitlochry, Noman; Forres, lieuter.

G. gibbifera, Schum-Black, in shape much like $G$. Coste, having the mesopleura very wide across the region of the intermediate coxa; pronotum with a small yellow streak indicating the anterior extremity of the dorsal line, and a submarginal yellow streak on the posterior lobe only; connexirum broadly yellow; legs brownish yellow, paler beneath; anterior femora black above, underside clothed with silvery hairs, a spot on each of the sheaths of the coxa, and a central line extending from the metasternum to the apex of the body yellow; metasternum with a yellow tubercle in the centre; central line of the abdomen carinated; first joint of the posterior tarsi very long, twice as long as the second.

L. $12 \mathrm{~mm}$.

Common, and generally distributed in the South of England, but not recorded, so far as I know, from Scotland or Ireland.

G. lacustris, Lim.-Black, narrower than the preceding. Pronotum with the submarginal yellow band continued on to the anterior lobe; central carina strong, especially posteriorly; legs pale, the anterior femora with two black lines; connexivum pale; abdomen beneath silvery, its centre more or less widely pale in the o ; posterior tibix and tarsi together almost as long as the femora; 
abdomen simple in the $\delta$, first genital segment in the $q$ square, carinated beneath.

L. $10 \mathrm{~mm}$.

Common, and generally distributed.

G. odontogaster, Zctt.-Exceedingly like lacustris, but distinguishable by the rather smaller size, the longer intermediate tarsi in proportion to their tibice, the black anterior femora, which are only reddish yellow at the base, the wider genital segments in both sexes, the first segment in the o being transverse and impressed at the base beneath; in the $\delta$ the sixth abdominal segment beneath bears two strong teeth, which incline forwards; posterior tibir and tarsi together not much shorter than the femora.

L. $8-9 \mathrm{~mm}$.

Not so common as the preceding, but generally distributed; occurs both in Scotland and Ireland.

G. argentata, Setum.-Smaller than either of the preceding, dorsal keel of the pronotum less raised posteriorly than in lacustris, anterior femora dark as in odontoyaster; pronotum rather more widely rounded posteriorly than in either, with slight silvery pubescence just within the apical margin; posterior tibiæ and tarsi together much shorter than the femora; abdomen beneath simple in the $\delta$, of with the first genital segment carinated, whole underside very densely clothed with brilliantly silvery hairs.

I. $7 \mathrm{~mm}$.

Not common, Reigate, Chobham; Lincolnshire, $J . E$. Mason; Norfolk, Edwards; Battle, Butler; Sutton Coldfield, Blatch; Parley Heath, Woolmer, New Forest, Dale.

\section{REDUVIIDE.}

This extensive family is only represented in Britain by six genera and sixteen species, of which latter ten belong to the genus Nabis. In P'utou's Catalogue over 140 species 
are recorded as Palaarctic, belonging to twonty-nine genera. The species are carnivorous.

The family may be distingrished by its short, bent rostrum, which does not lie agninst the under surface of the head when in repose, its filiform antenne, its prominent eyes, situated as a rule far away from the pronotal margin, and its ocelli (when present) situated behind the eyes; elytra often not fully developed, but when developed, consisting of corium, clavus and membrane; legs with the anterior femora generally incrassated, although scarcely so in Ploiwria, in which genus all the leg's are exceedingly thin and elongate.

\section{TABLE OF SUBFAMILIES.}

(2) 1. Anterior coxæ very elongate, extending beyoud

the apex of the head . . EMesina.

(1) 2. Anterior coxa not elongate .

(4) 3. Rostrum three-jointed . . . . Reduvins.

(3) 4. Rostrum four-jointed : : : N

\section{EMESINA.}

\section{PLOIARIA, Senp.}

Elongate, with extremely long, fine antenna and legs. Head rounded posteriorly behind the eyes, eyes prominent, ocelli wanting, vertex with a strong transverse impression; antenniferous tubercles strongly developed; antennæ very long, first and second joints subequal, third and fourth together about half as long as the second; rostrum scarcely longer than the head; pronotum slightly widoned behind, its sides nearly straight and carinated; scutellum with two spines, one at the base the other at the apex, below the apical one is another, which appears to me to be on the basal segment of the abdomen, although Dr. Puton considers it "sur le scutum du metathorax;" elytra submembranous, membrane very large, corium produced along each side of it into a long, narrow point; leg's very long and thin; coxre elongate, especially the auterior pair, which are 
produced beyond the aper of the head; anterior femora slightly thickened, much shorter than those of the other legs; tarsi short, three-jointed.

We have two species in this country, out of five recorded by Puton in his Catalogne. They occur in such localities as ivy, thatch, etc., and are amongst the most beautiful and delicate of the Hemiptera.

(2) 1. Larger, apical joint of the antenna not a third as long as the third, antennx and legs pilose, except in rare cases :

(1) 2. Smaller, apical joint of the antennw nearly half as long is the third, antenne and legs glabrous, except in rare cases . . coliciformis.

VAGABUXDA.

P. vagabunda, Linn.-Pale ochreous, extremely narrow and delicate, antenne much longer than the body, annulated with black, finely pilose, second joint slightly shorter than the first, third not half the length of the second, fourth about a third as long as the third; pronotum pale ochreous, lateral carinæ and margin white, dise flat, in front with two diagonally placed tubercles, hind angles raised, base straight; scutellum with two spines, one at the base, the other at the apex; elytra mottled with grey, especially on the membrane; base of the abdomen with a spine, like those on the scutellum; legs annulated with black, pilose.

L. $6-7 \mathrm{~mm}$.

In ivy, Chobham, Bideford; Mickleham, Headley Lane, Reigate, Billups; Ewhurst, "firs," Muswell Hill, "on palings," Battle, Shalford, "ivy," Barnet, "oak," Butler; "fir-trees," Norfolk, Edwards; Colwgn Bay, Beaumont; Knowle, Boxhill, Bristol, Blatch; Buggrooke, North Hants, Nunton, Wilts, in houses, Marshall; Morayshire, Norman; Glanvilles Wootton, Freshwater, Dale.

P. culiciformis, De G. (erratica D. \&. S.)-Very like the preceding, but smaller, the antenna shorter, being only about equal to the entire insect in length, their apical joint being about half the length of the third; they are also glabrous, or" in rare instances slightly pubescent; the black markings are 
more extensive on the elytra, and the legs are golabrous; spine at the base of the scutellum slightly longer.

L. $5 \mathrm{~mm}$.

In my Synopsis, 'Trans. Ent. Soc, 1876, p. 623, I describe the scutcllar spine of this species as "almost obsolete;" this statement is utterly at variance with the fact, and I can only suppose I had a specimen before me with the spine broken ot:

In thatch, Reigate, Chobham; Lastingham, Yorkshire; Norfolk, Eulwords; Glanvilles Wootton, Dule.

\section{REDUVIINA.}

(") 1. Head parallel-sider behind the eyes

(1) '. Head much constricted behind the eyes.

(1) $i$. Head suddenly constricted posteriorly into a parallel-sided collar . . .

(i) 4. Head gradually constricted in converging lines from behind the eyes to the margin of the pronotum.

Prgolatisis.

ReDUTIUS.

Corantes.

\section{PYGOLAMPIS, Germ.}

Of this curious genus we have only one out of the three Palzarctic species recorded by Puton, and its place in our list depends on a solitury record; still, as it is sare all over Europe, we may hope to meet with it again. It is so unlike any other of our genera that it may be distinguished without difficulty. Elongate, head as long as the pronotum, parallel-sided from the base to the insertion of the antennx, eyes prominent, placed about midway between these points, behind the eyes beneath are two groups of spines; central lobe of the face much produced and pointed, cheeks beneath serrate; basal joint of the antennx thick, slightly tapering to the apex, nearly as long as the bead, the rest thin; rostrum short and very thick; pronotum elongate, widest behind, sides and base straight; scutelltum simple; corium aud clavus narrow; membrane very large; conuexivum wide, reflexed; anterior femora slightly incrassated, pos- 
terior pair very long; tarsi three-jointed; pronotum with its inferior margin produced into a curved spine; anterior coxa contiguous, intermediate pair slightly separated, posterior pair very remote; genital segments in the male triangular. I do not know the female.

P. bidentata, Fourer. (bifireata, D. \& S.).-Dull brown; second joint of the antenna about once and a half as long as the first, third about a third as long as the second, fourth about twice as long as the third. Head divided into two portions by a deep transverse channel between the eyes, the posterior portion nearly square, with a central channel; posterior margin with four blunt spines; beneath, the anterior group of spines consists of three, the posterior of four; pronotum trapoziform, Hat, with four indistinct carinæ, the two central ones strongest, enclosing a triangular impression at the base; scutellum small, simple; elytra dull brown, nerves shining; connexivum with pale spots at the joints of the segments; legs paler, anterior and intermediate tibia banded with blick; posterior femora black at the apex.

L. $16 \mathrm{~mm}$.

Under a piece of red sandstone, Quatford, Salop, September, Thos. Marshall.

REDUVIUS, $F u b$.

Subelongate. Head small; neck narrow, parallel-sided; ocelli large, prominent, situated just behiud the eyes; eyes very large; antenniferous tubercles almost touching the eyes at their base; face, between the antenne, tricarinate; antennæ very long, setaceous, basal joint thickest; rostrum thick, short, and curved; pronotum much widened behind, anterior margin raised and callose; disc with a transverse impression across the middle, and a deep longitudiual impression widened posteriorly; scutellum large, impressed at the base; elytra longer than the abdomen; corium very 
long and narrow; membrane very large, hardly differing from the corium in texture, its nervures enclosing two large cells; anterior femora slightly incrassated, their tibia widened at the apex; coxa not very remote, but the posterior pair more so than the others; male with one genital segment visible, female with three.

R. personatus, Limn.-Pitchy brown, inclining to black, clothed with fine hairs, shining. Antenne with the second joint about twice the length of the first, second and third subequal, fourth rather shorter; ocelli promineut, yellowish; pronotum with the anterior angles prominent, the anterior margin raised, consideralsly wider than the base of the head; pronotum raised, rounded and smooth in f'ont, transversely wrinkled behind; transverse impression moderately deep, dorsal one wide posteriorly, and very deep; base rounded; scutellum with a triangular impression at the base; elytra brown; legs with the extreme base of each tibia pale.

I. $16^{\circ}-17 \mathrm{~mm}$.

Generally distributed, but apparently nowhere common. It is a destroyer of other insects, and is said to feed on Cimpx lectulurias, Dipteru, etc. It is probably chiefly a night feeder, as it often flies to light in windows, etc.

\section{CORANUS, Curt.}

Head wide across the eyes, which are very prominent, gradually narrowing posteriorly to the pronotur; face long, declivous in front; antenniferous tubercles situated in front of the eyes; antenux, first joint very short, second subequal to the fifth, third and fourth together about equal to the first, third slightly shorter than the fourth; betwecn the eyes is a deep curved impression, behind which are placed the ocelli; rostrum thick, curved, reaching to about the middle of the prosternum; pronotum widened posteriorly, deeply constricted in the centre, its anterior puargin straight; base sinuate; scutellum raised into a 
blunt upright spine; elytra rarely developed in this country, reaching only to about the apex of the second abdominal segment, narrow, with a short membranous apex; in developed specimens the corium is long and narrow, the membrane large, its nerves enclosing three cells, of which the apical one is the longest; connexivum much reflexed, its sides rounded; abdomen beneath very convex; all the femora with a slight annular swelling near the apex; tarsi three-jointed; one genital segment visible in the $\delta$, two in the $q$.

C. sub-apterus, De G.-Greyish black, head, pronotum, and legs clothed with long erect hairs. Head with a pale line down the centre behind the eyes, and a pale line along their inner margins; antennæ slightly piceous, second joint with long erect hairs, fifth joint longer in the of than in the $\delta$; between the second and third, and third and fourth, and fourth and fifth joints are short supplementary ones, so that counting these the antenu» would bo eight-jointed; pronotum with the anterior margin straight, its angles right angles, disc raised behind it and rounded, then transversely impressed, and again slightly raised to the base; sides deeply sinuate; posterior angles largely rounded; base sinuate, disc posteriorly with three longitudinal depressions; scutellum with the spine often more or less pale; elytra as described above; counexivum with a pale band on each segment; legs with paler rings.

L. 10-11 $\mathrm{mm}$.

Heathy places, Woking, Deal; Addington Hills, Weybridge, Douglas and Scott; Sandwich, Pegwell Bay, Freshwater Bay Pembrokeshire, Milford, Aturshall; New Forest, Blatch; Bournemouth, Fowler; Deal, Battle, Camber, Shalford, Ewhurst, Butler; Land's End, Dale; Norfolk, Edwards. Has a distinct scent when alive, which Messrs. Douglas and Scott compare to that of "ripe pears." 


\section{NABIDINA.}

(2) 1. Pronotum smooth shining, colour black and

(1) 2. Pronotum not shining, colour ochreous or

ilull brown . . . . . Nabis.

Prostemia.

\section{PROSTEMMA, Lap.}

This beautiful genns has but slender claims to be admitted into our lists, but the three records of its capture are all. well authenticated, so that it can scarcely be omitted. It may be known from all its allies by its scarlet and greenish-black colours, its smooth, highly-polished head and thorax, dull flat scutellum, largely incrassated front femorn, denticulated beneath, and the angulately produced apices of the front tibiro; tarsi threc-jointed.

P. guttula, Fub.-Head, pronotum, scutellnm, and abdomen greenish black, legs and elytra scarlet, antenna pitchy brown. Head and thorax highly polished, with long scattered hairs, the latter punctured and impressed near the base, longer than wide, sides slightly ronuded, diverging to the posterior angles; scutellim and elytra dull. Only the undeveloped form has been taken in this country, in which the elytra are truncate posteriorly, the membrane very short and transverse, not quite reaching to the apex of the second abdominal segment; abdomen punctured. In the developed form the elytra reach to the apex of the abdomen; the aper of the corium is black, the membrane greyish black, with a white spot on each side below the apex of the corium.

L. $9 \mathrm{~mm}$.

One specimen taken at Chariton, Kent, by Mr. E. W. Janson, which is now in my collection; one recorded by Curtis, from the sandhills near Sandwich, taken by Mr. A. Kennedy, in September, 1837 ; and one taken in recent gears by Mr. Sidehotham. 
NABIS, Latr.

A genus of pale ochreous, brown, or in one continental species, green insects, of which we have ten in this country out of the twenty recorded as Paliarctic by Puton. All our species occur on or amongst low-growing plants, except brevipennis, which is found on nut bushes.

Head with the eyes large, more or less remote from the anterior margin of the pronotum; ocelli situated slightly behind the eyes, one on each side of the central dorsal line; antenniferous tubercles not prominent; antennæ filiform, five-jointed, reckoning the very short joint which follows the first; rostrum slender, reaching to the first or second pair of coxæ; pronotum elongate, constricted into a narrow simple collar in front, considerably widened posteriorly; sides nearly straight; scutellum simple, or depressed at the base; elytra often undeveloped, in some species almost always so, consisting in macropterous specimens of corium, clavus, and membrane, the last having two large cells at the base; in brachypterous individuals these cells are wanting, or the whole membrane may be absent, and the corium much shortened and truncate; abdomen with the connexivum generally more or less dilated; terminal genital segment in the male beneath very large, styles visible from above, and often affording specific characters; in the female two segments are visible above, and the ovipositor can be seen beneath; legs moderately long, anterior femora slightly incrassated, intermediate tibire denticulate along their inner margin, tarsi three-jointed.

(6) 1. Connexirum more or less reflexed, not separated beneath from the central portion of the abdomen (Subg. Aptus, Stål.).

(5) 2. Connexivum dark, with reddish or yellow spots.

(4) 3. Tribiz on their external margin with long semi-erect hairs, antennas longer than the body . . . BRErIPENxIS. 
(3) 4. Tilix externally with short decumbent bairs, antenne shorter than the body . . . . .

(4) 5. Conzexivum pale : -

(1) 6. Connexivum beneath separated from the central portion of the abiomen by a distinct channel.

(8) 7. Eyes very large, almost touching the pronotal margin, counexivum dark (Sulog. stcilia, Reut.) . . . Boops,

(7) 8. Eyes moderate, remote from the pronotal margin, connexivum pale (Subgr. Nubis, Latr.).

(14) 9. Abumen above finely pubescent.

(11) 10. Alutomen above dark, with pale central lines . . .

(10) 11. Abdomen above pale, with darter lines.

LATIVENTRIS

MAJUR.

BOOPS.

(13) 12. Not very elongate, connexivum wide, foliaceous. . . Limbatus.

(12) 13. Very long and parallel-sided, connexirum maror, not foliaceous. Lineatus.

(9) 1t. Abdomen above glabrons.

(16) 15. Pronotum at tlie base wiler than long. . . . PERUS.

(15) 16. Pronotum at the base narrower than long.

(18) 17. Wider, paler, occurs in grassy places, ete. . Rugosus.

(17) 18. Narromer, darker, redulish brown, found on heath . . . . ERICETORUs.

N. brevipennis, Hahn.-Brown, clothed with short, silvery pubescence. Head with two pale spots just in frout of the pronotal margin on the shining part of the neck; antenno longer than the body, with the basal joint as long or longer than the lead; pronotum with its sides rounded behind the anterior constriction, and slightly sinuate before the posterior augles, base nearly straight, dise darker across the middle and convex, with a deep trausverse depression behind; scutellum black, sometimes with a pale basal spot on each side; elytra pale browu, marbled with darker, almost always shortened to abont the apex of the third abilominal segment, membrane dusky; abdomen dark bronzy brown, subparallel-sided in the male, largely dilated 
in the female; connexivum reflexed, with reddish spots at the apices of the segments, sixth segment with its angles rounded; legs long, ochreous, mottled with brown, and clothed with long hairs.

L. $8-10 \mathrm{~mm}$.

I have never seen a developed British specimen, but have a $f$ continental one, in which the mernbrane reaches beyond the apex of the abdomen and is irrorated with small obscare spots.

On Corylus, August and September; Wimbledon, Bromley, Kent; Headley Lane and Weybridge, Billups; Sterenage, Pattle, Butler; St. Osyth, Blatch; Quatford, Milford, Darenth, Marshall; Glanvilles Wootton, Date.

N. lativentris, Boh. (apterus, D. \&. S.).-Smaller, but similar to the preceding in colour, being brown mottled with darker brown; the antennw, however, are shorter, not being so long as the entire insect, and the basal joint not so long as the head; the elytra, though generally shortened, reach to the fourth or fifth abdominal segment; the connexivam is more dilated in the $\sigma$ and less dilated in the o than in brevipennis, the connexival spots are paler, and the sixth segment has distinct lateral angles; the femora are shorter, and the tibiro want the exserted long hairs of that species.

L. $6 \frac{1}{2}-7 \mathrm{~mm}$.

Developed form very rare. I have a $q$ taken at Bournemouth.

Generally distributed, and common by sweeping.

N. major, Cost. (pilosulus, Fieb; flaromurginatus, D. \& S.).-Ochreous brown, clothed with fine black hairs. Head elongate, with a dark central stripe, face nearly horizontal; antennæ ochreous, first joint black at the base; pronotum at the base about as wide as long, anterior margrin not lalf the width of the base, sides rounded in the 
middle, base slightly sinuate, dorsal line and a line close to each side black; scutellum with its centre impressed and black; elytra always developed, nerves pale, the interstices durker brown, membrane pale brown, nervures black; abdomen black, connexivum pale, or with darker spots at the apices of the segments in the $\delta$; legs pale ochreous, with the femora spotted with brown, anterior pair with a liroad black longitudiual stripe, posterior pair black at the apex.

L, 7 $7-9 \mathrm{~mm}$.

Common in many localities in rubbish, by sweeping, etc., and generally distributed.

N. boops, Schioilt.-Similar in colour to the preceding, but otherwise quite different, its short, compact form distinguishing it at once. Head short, as wide across the eyes as long, these latter very large, each being as wide as the space between them, and when the head is thrown back almost touching the pronotal margin, face nearly vertical; pronotum with the sides and base nearly straight; elytra reaching to the fourth abdominal segment; exterual margin of the corium largely rounded, central nerve dark, membrane very narrow, not produced beyond the apex of the corium; abdomen black, shiniug; connexivum reflexed, with obscure reddish spots, and separated beneath by a distinct furrow from the central portion of the abdomen; legs short, front femora black posteriorly, intermediate pair with a black stripe near the apes, posterior pair with the apex widely black.

L. $7 \mathrm{~mm}$.

Very rare; Mousehold Heath, near Norwich, Edwards; Gomshall, Surrey, under heath and at roots of grass, and Sandhills, Lorrestoft, Butler.

N. flavomarginatus, Scholtz.--Ochreous. Head with a broad central black stripe; antenno with the basal joint shorter than the head, second joint narrowly black at the 
apex; pronotum with its sides slightly rounded in the middle, base straight, anterior constriction and base smooth and pale, centro with darker markings and more or less cicatricose, dorsal line throughout, and a wider lateral line in front, black; scutellum black, with a pale spot on each side near the apex; elytra reaching to the third segment, ochreous, nerves slightly paler; developed form rare, but with the membraue reaching to the apex of the abdomen, whitish, its nervures brown; abdomen finely pubescent, black, with two narrow pale lines down its centre; connexivum pale, foliaceous, narrow in the $\delta$, wide in the $q$, divided from the rest of the abdomen beneath by a distinct furrow; legs pale ochreous spotted with brown.

L. 8-9 $\mathrm{mm}$.

Deal, Herne Bay, Chobham, Woking; Reigate, Cowbridge and 'I'aff's Well, South Wales, Billups; Grange, Lancashire, B. Coolie; Norfolk, Elwards; Loch Rannoch, Marshall; Pitlochry, Norman; Sandhills, Lincolnshire, $J$. E. Mason; Bath, Bluthwayt; Armagh, Johnson; Guestling, E. P. Collett.

N. limbatus, Dahll.-Narrower, paler, and more depressed than the preceding. Head very long and narrow, ochreous, its sides in front of the eyes subparallel, eyes large; first joint of the antennx longer than the head; pronotum ochreous, narrow, and collar-like in front, sides slightly rounded in the middle, base in undereloped specimens twice as long as the anterior margin, nearly straight, disc raised across the middle with darker markings and more or less cicatricose, dorsal line grey; scutellum ochreous, with a grey dorsal line and a small basal fovea on each side; elytra in the undeveloped form very short, not longer than wide, ochreous, membrane very small, almost linear; abdomen ochreous, subparallel-sided in the male, dilated in the $q$, with a narrow black central stripe 
and a wider greyer one on each side; connexivum slightly reflexed, foliaceous, narrow in the $\delta$, wide and rounded at the sides in the $q$, and often with a red longitudinal streak down its middle; legs pale ochreous, long and slender, femora spotted with small brown spots.

L. 8-9 mm.

Common and generally distributed, by sweeping amongst grass, etc. Developed form exceedingly rare.

N. lineatus, Dahlb. (Poweri, Saund. Synopsis).-Much longer and narrower than limbatus. Head longer and narrower, with the sides behind the eyes more swollen; pronotum longer and more regularly trapezoidal, the sides being practically straight; scutellum larger than in $7 \mathrm{im}$ batus, with a dark dorsal line and a larger fovea at each side of the base; elytra in the undeveloped form (the only one I lave seen) short and truncate, reaching to the apex of the first abdominal segment; abdomen very long and narrow, quite parallel-sided in the male, and only very slightly widened in the centre in the female; both sexes have the connexivum quite narrow and costate, not foliaceous; legs very long, pale ochreous, the femora with small brown spots.

I. 11-12 $\mathrm{mm}$.

By sweeping, at the roots of grass, etc., geverally in damp situntious; Chobham, Southwold, Herme Bay; Horuing, Surlingham, Cley, Edwards; 'Irustthorpe Sandhills, Lincolnshire, J. E. Masun; Oxshott, Billups; Camber Sandhills, E.P. Collett; Fritton near Lowestoft, Butler.

N. ferus, timn.-Pale greyish ochreous. Head about twice as long as the width between the eyes, with a dark, wide central line narrowing to the base; antenno with the basal joint shorter than tho heud, second joint about as long as the pronotum; pronotum much widened posteriorly, base three times as wide as tho anterior margin, sides 
slightly sinuate, posterior angles rounded, slightly produced, base nearly straight, disc raised posteriorly, with a dark central line, wide in front, very narrow on the basal elevation, surface dull, clothed with exceedingly fine silvery pubescence; scutellum black, with the sides yellow; elytra developed, pale ochreous, nerves pale, sometimes more or less margined with brown; central nerve of the corium with two small black spots towards the apex; membrane large, pale, with brown nerves, and with a small black spot near the external angle of the corium; abdomen above black or brownish; comnexivum pale, beneath pale with a broad stripe down each side and the centre brown; leggs ochreous, femora spotted with brown.

L. $8 \mathrm{~mm}$.

Common and generally distributed, by sweeping.

N. rugosus, Limn. (dorsalis, D. \& S.).-Of a more yellowish-ochreous colour than ferus; antenna longer, the second joint much longer than the pronotum, eyes larger and more prominent; pronotum much longer in proportion to its width, the sides straight or slightly rounded in the middle, the base not more than twice as long as the anterior margin; eiytra less parallel-sided, nerves very strong and pale, central nerve of the corium with spots as in ferus; membrane rarely fully developed, extending slightly beyoud the apex of the corium.

L. 7-8 $\mathrm{mm}$.

Common and generally distributed; by sweeping amongst nettles, grass, etc.

$\mathbb{N}$. ericetorum, Schlt $\ldots$-Differs from the preceding in the slightly shorter antennæ, the narrower form, and the darker and more rufescent colour.

L. $7-8 \mathrm{~mm}$.

Common and generally distributed, but only occurring on heaths; probably a variety of rugosus. 


\section{SALDID丑.}

Of this family we huve only one British genus, out of the three genera known as European. The Saldidre are peculiar in their habits, most of them frequenting the sides of streams and marshy places, especially salt marshes, where they live on the mud, under and amongst saline plants, such as Arenaria, Salrola, etc; orthochila, however, is found on heaths, and does not appear to care for moisture. Ar. J. E. Mason, Ent. Mo. Mag., Xxv., p. 236, gives an interesting account of the habits of Salda lateralis and saltatoria, and remarks that they are able to live for" some time under water; in some cases he watched the insects crawling from one plant to another under water. At p. 237 he says:- "I watched one until the receding tide left it, after near an hour's submersion; so long as its body and surroundings were wet, it showed nothing of its usual wariness and activity, and was easily taken up with the fingers." Under ordinary circumstances, as all know who have tried to capture them, they are most agile, and run ant jump freely. The family may be briefly characterized thus :-

Species slightly convex, oval, eyes very large and prominent, ocelli placed between the eyes, two in number in the Saldina, three in the Leptopina, of which we have no British representative; antenne filiform, slightly thickened towards the apex; rostrum three-jointed, not lying against the prosternum; pronotum rariable in form, but with the lateral margins always carinate, the base largely sinuate; scutellum large, depressed at the base; elytra composed of corium, clavus and membrane, exterior margin of the corium rounded and reflexed, membrane often more or less abbreviated, with four long subparallel cells, their apices subparallel to the apical margin of the membrane; abdomen with three genital segments exposed in the $\delta$, three in the o above, but covered beneath by the extensive sixth segment; legs moderately slender, tarsi threo-jointed. 
SALDA, Fab.

The characters of this genus are given above in those of the family. All the species have a common facies, although the small group with contiguous ocelli, to which Stål has given the subgeneric name Chartoscirta, has the pronotum more constricted in front and its sides sinuate. There are thirty-nine species given in Puton's Catalogue, of which we have seventeen in this country.

(28) 1. Ocelli not contiguous.

(5) 2. Lateral margins of pronotum pale.

(4) 3. Larger, broad-oval, clothed with upright

(3) 4. Smaller, narrowed in front, glabrous : : PIlosa.

(2) 5. Lateral margins of pronotum black.

(9) 6. Lateral margins of corium black, with a conspicuous yellow spot near the apex, sides of pronotum straight.

(8) 7. Pronotum narrow, its base hardly wider than the head across the eyes. . . . RIPARIA,

(i) $\therefore$ Pronotum wide, its base much wider than the head :

(ii) 9. Lateral margin of corium black or spotted, but without a conspicuous yellow spot near the apex, sides of pronotum rounded or straight.

(15) 10. Species large, 5-6 $\mathrm{mm}$.

(12) 11. Upper surface with long upright hairs . E scotica. pubescence.

(14) 13. Glabrous, shining .

(13) 14. Clothed with short golden pubescence, dull : LITTORALrs. L

(10) 15. Species small, $3-4 \mathrm{~mm}$.

(19) 16. Pronotal margins straight, elytra without silvery hairs.

(18) 17. Lateral margins of corium with a reniform yellow spot in the middlo

(17) 18. Lateral margins of corium narrowly pale

(16) 19. Pronotal margins slightly rounded, or, with ORTHOCHILA.

(21) 20. Short, elytra black, with very small patches of silvery pubescence, margins largely

pale at the base and apex . . Marginalis.

(20) 21. Oval, elytra without silvery hairs.

(23) 22 . Coal black, a conspicuous white spot near the centre of the lateral margin of the corium

C. $\triangle \mathrm{LBUH}$.

OPACULA.

AREXICOLA. 
(22) 23. Of a less deep black, without the conspicuous marginal spot on the corium, corium sometimes entirely pale.

(27) 24. Upper surface not clothed with semi-erect hairs.

26) 25. Spots more distinct, less confluent, front tibix dark at the base, centre, and apex

(25) 26. Spots less distinct. more confluent, elytra sometimes almost entirely pale, front tilise with a continuous lark line from the base to beyond the midlle

(24) 27. Upper surface clithed with semi-erect hairs:

(1) 28. Ocelli contiguous, jronotum with two traus. verse rows of punctures, one just behind the front margin and the other in the transverse impression.

(32) 29. Surface clotbed with black bristly hairs.

(31) 30. Third and fourth joints of the antenuso black and much thickened for antennix not

(30) 31. Third and fourth joints of the antennæ not

(29) 32. Surface without black bristly hairs

S. pilosa, Fall.-Broad-oval, black, with pale markings, clothed with fine golden pubescence, and with long, erect, black hairs. Head black, with a line along the innor margin of each eye, and the face in front ochreous; anteuna ochreous, clothed with long hairs, third and fourth joints infuscate; pronotum black, very transverse; anterior margin shortly constricted; sides dilated and reflexed, ochreous, nearly straight; posterior angles rounded; base very deeply siuuate; disc punctured, slightly raised in front with a shallow central impression in the raised portion; scutellum black; elytra black, punctured, with ochreous spots, which tend to be more or less confluent, sometimes almost entirely pale; sides of the corium rounded; membrane with the nervures dark or pale, sometimes with dark spots between them; abdomen black or brown; connexivum pale; legs ochreous, clothed with bristly hairs, and with a black line under each of the femora.

L. $5-6 \mathrm{~mm}$.

Local; Pegrvell Bay, Southwold; Ravenglass, Dale; Margate, Billrips; Wells and Hunstanton, Edwurds; Haliday Collection; New Passage, Bristol, Reed; Broughton, 
Lancashire; Burnham Norfolk, and Sandwich Kent, Curtis ; Sheppey, Walton-on-Naze, Champion.

S. lateralis, Full. (var. mulchellu, Curt., D.\& S.).-Shining, punctured, black and ochreous, glabrous, sides of pronotum pale. Head black; face infront ochreous; antenne ochreous, darker on the third and fourth joints, basal joint with a black spot beneath; pronotum black, with the lateral margins narrowly pale throughout, or with the pale colour much widened at the base; sides nearly straight, reflexed; posterior angles acute; base deeply sinuate; dise with a deep transverse punctured impression, raised in front of it, the elevation with three fover; scutellum black, sometimes pale at the apex; elytra somerhat parallel-sided in the $\delta$, much dilated posteriorly in the $\&$, rarely fully developed, varying in colour from black, with the margins only pale, through more or less spotted varieties to entirely pale; as a rule the dark specimens are males; in the developed form the membrane is longer than the abdomen, pale, with brown nerves; abdomen black, or pale at the sides; apical segment pale; legs pale; femora with black stripes.

L. $4-5 \mathrm{~mm}$.

Worthing, Deal; Sheppey, Whitstable, Champion; salt marshes, Hunstanton, Elwards; Mumby Chapel, Lincolnshire, J.E. Mason; Hayling, Margate, Billups ; Lymington, Weymouth, Blatch; Topsham, Devon, Parjitt; Rye, Collett; Haliday Collection; Portland, Dale; St. Ives, Cornwall, Meson; Forres, Norman.

7 S. riparia, Fall. (conspicua, D. \& S.).-Velvety black, with a grey sheeny pile, and with rather deep yollow markings. Head black, lobes of the face, and a spot along the side of each eye yellow; antennæ long and stout, first joint yellow beneath; pronotum with the anterior margin narrowly constricted, the constriction longer than in most of the species; sides suddenly widened behind the constriction, straight, slightly reflexed; posterior angles acute, base deeply sinuate, about as wide as the head across the 
eyes; disc much raised in front, with a central forea in the elovation; elytra dull, spotted with yellow, with the sides rounded, and with a conspicuous large yellow spot just above the apex of the corium; membrane yellowish, its nerves black, with a black spot in each cell, inmost cell much shorter than the second; abdomen black; legs dusky ochreous, femora rather darker.

L. $5 \mathrm{~mm}$.

Easily recognized by its narrow, straight-sided pronotum ; Rannoch, Perthshire, Mlurshall and Rye; Aviemore, Snowdon, Chrmpion.

S. orthochila, Fieb.-Black, with yellow spots. Head black, a spot near each eye, and the face at its apex pale; antemne slender, with the basal joint pale, with a black stripe at the side; pronotum widely transverse, anterior constriction very short, sides straight, posterior angles obtuse, base much wider than the head across the eyes, deeply sinuate, raised portion of the disc in front with a small deep fovea; elytra clothed with fine greyish pubescence, and spotted with small oval yellow spots, generally with a larger spot on the lateral margin, just above the apex of the corium; membrane yellowish grey, bluck at the base; nervures black, and with a black spot below the apex of the corium, the interval between them yellow; abdomen black; legs yellow, tibia at the base and apex narrowly black, front femora with a black spot, apical joint of the tarsi black.

L. 4-5 $\mathrm{mm}$.

In sandpits and on sandy commons, etc., often away from water; Woking, Charmouth, Ilfracombe, Penzance; Shirley, Dulwich, Billups; "abundant under Erica," Mousehold Heath, Norwich, Edwards; Corton, Lowestoft, Butler; Dartmoor, Cannock Cliase, Barmouth, Isle of Man, Blatch; Spridlington Lincolnshire, J. E. Mason; Exmouth Warren, Parfitt; Armagh, Johnson; Forres, Nornan; Shetlands, Reuter; Wombury, Haldon, Dawlish, Bignell. 
S. scotica, Curt. (riparin, D.S.S.).-Elongate oval, black, elothed with erect black hairs, elytra with small oval ochreous spots. Antenne with the second joint subequal to the third and fourth together; pronotum with the sides straight, narrowly reflexed, fringed with long hairs, postorior angles obtuse, base widely and deeply sinuate across the scutellum, dise with a strong transverse impression and a tubercular elevation subdivided in the middle in front of it; scutellum convex, with a strong central impression; elytra with the sides slightly rounded, the pale spots placed one near the apex of the clavus, two between the central norves of the corium, and four along the apical margin of the corium; all these vary in size, and are liable to be absent; membrane fully developed, smoky, black at the base, nervures black; legs, with the apices and sides of the femora, the apices of the tibix and the bases of the anterior pair, and the second joint of all the tarsi, pale.

L. $6 \mathrm{~mm}$.

Lustleigh Cleave, Dartmoor, Lastingham, Rannoch, Marshall; Church Stretton, Breeon, Blatch; Strathglass, F. B. White; Morayshire, Forres, Norman; Perth, Reuter; Llantrissant, Billups ; Ullswater, Belfast, Dale; Bettrs$\mathrm{y}$-Coed, Wales, Irollaston; Isle of Bute and Cartland Craigs, Curtis; Willaston, Cheshire, J. W. Ellis; Newcastle (Ireland), Champion.

S. littoralis, Linn.-Short oval, dull, black, without erect hairs, but clothed with very fine adpressed golden pubescence; elytra with very small inconspicuous pale spots, or entirely black. Antenna with the first and second joints piceous, second distinctly shorter than the third and fourth together; pronotum with the sides behind the anterior constriction slightly rounded, widely reflexed; posterior angles acute, blunt at the apex; disc with a deop transverse impression, raised and rounded in front of it, with a small round fovea in the front of the elevation; scutellum with a deep central impression, transversely wrinkled posteriorly; 
elytra with the spots, when present, placed, one on the clavus, and three or four along the inner nerve of the corium; membrane very short, smoky, nervures thick, black; legs brownish ochreous, a line under each femur, and a fer spots, blackish; apex of the tarsi black.

L. $6-7 \mathrm{~mm}$.

Common and generally distributed, in salt marshes.

S. morio, Zett.-Black, shining, glabrous, legs piceous or testaceous, darker in the $q$. Eyes very large; antennse finely pilose, third and fourth joints together distinctly longer than the second, second and the first in the of above more oi. less piceous; pronotum with the sides behind the anterior constriction stright, or in the of very slightly curved, widely reflexed; posterior angles acute, blunt at the apex; dise narrowly impressed at the base, raised, rounded, and shining in front, with a small rounded central fovea near the anterior margin; scutellum with a central impression, punctured in front, shining and somewhat wrinkled behind; elytra very shining in the $\delta$, less so in the \&, their sides rounded; membrane black, very short, sometimes slightly paler between the nervures; legs testaceous or pitchy, with the femora widely black in the $q$; apices of the tibire and tarsi black.

L. $6-7 \mathrm{~mm}$.

On the moors, near Buxton; Scarborough, Lawson; Whittlesea Mere, Dale; shores of Loch Rannoch, Marshall; Brumstead Common, Norfolk, Edwards; Horning, Aviemore, Champion.

S. C. album, Fieb. (stlllata, Curt.).-Short oval, black, clothed with fine golden pubescence; elytra with grey and yellow markings, with a conspicuous reniform yellow spot in the centre of the lateral margin. Head with the mouth parts yellow; antenne with the first and second joints pale, the second sometimes blackish towards the base; pronotum short, transverse, sides behind the anterior constriction straight, widely impressed and reflexed, base deeply 
sinuate across the scutellum; disc with a wide transverse impression and a small round forea in the raised portion in front of it, bounded posteriorly by two small tubercular elevations; elytra short, sides much rounded, with numerous yellow and greyish-white spots, a conspicuous large reniform yellow spot on the centre of the lateral margin, and a small round white spot near the apex of the corium; membrane yellow, nervures and a spot in each cell black; legs testaceous, femora spotted with black; tibia with the base and aper, and in the first and second pairs with a more or less distinct contral band, black; tarsi black at the aper.

L. $4 \mathrm{~mm}$.

I cannot bring myself to agreo with Professor Reuter in considering vestita, D. \& S., as the developed form of this species; it wants the grey spots on the elytra, and especially the small round white apical spot, so characteristic of C. album; it also has the sides of the pronotum rounded. I therefore still place it as a variety of saltatoria.

Axwell Park, Newcastle, Lanercost, Cumberland, Bold; Isle of Man, liev. II. A. Stowell; Wareham, Blackgang Chine, Curtis; Selbourne, Isle of Wight, Dale; Cardiff, Corvbridge, South Wales, Billups; Strathglass, $F . B$. White; Morayshire, Forres, Noman; Perth, Reuter ; Birmingliam, Bervaley, Worcester, Matlock, Dean Forest, Swansea, Blatch; Saltcoats, Douglas; Brent and Bickleigh Vale, Deron, Bignell; shingle, banks of Dee, Llangollen, T. W. Ellis.

S. opacula, Zett.-Black, sides of pronotum straight (or scarcely curved in the $q$ ), lateral margins of corium narrowly pale, its disc moro or less spotted. Head with the mouth parts pale; antennæ black, first joint pale beneath; pronotnm with its sides straight, impressed, and slightly reflexed, base deeply sinuate, disc with a well-defined transverse impression, rounded and raised in frout of it, with a small central fovea in the elevation; elytra with 
the clivus cluthed with fine golden pubescence, corium with its entire lateral margin, except at the base and extreme apes, narrowly and evenly pale ochreous; disc with a few pale ochreous elongate spots, which tend to spread in longitudimal lines; near the apical angle is an elongate white spot; membrane ochroous, its nervures and a spot in cach cell black; legs ochreous, femora more or less spotted, tibia with their extreme base and apex black. tarsi black at the apex.

L. $3-3 \frac{2}{2}$ mn.

Scotland, Aviomore, Champion; Brnemar, Dr. F. B. White; Forres, Norman.

S. marginalis, Full.-Short oval, dull, black, sides of the corinm pale, the colour widening slightly at the base, and largely at the apex. Head with the mouth parts pale or piceous, first and sccond joints of the antennw pule, the first dark at the base in the 9 ; pronotum with the sides nearly straight, very narrowly reflexed, posterior angles acute, base deeply sinuate, disc with a straight transverse impression, raised in front of it, with a small central fovea; elytra short, with the sides much rounded; lateral margin of the corium ochreous, the colour not quite reaching to the base, wide at its origin, then much narrowed, and dilated again across the apical angle of the corium; disc unspotted, clothed with very minute patches of silvery hairs; membrane dusky, its nervures and cell-spots black, these latter often absent; legs ochreous, femora widely at the base, and tibia and tarsi at the extrome aper, black.

L. $2 \frac{3}{4}-3 \mathrm{~mm}$.

This very distinct little species is rare and local; $M r$. Butler and I have taken it on Chobham Common, and $M r$. Billups has taken it at Woking; Mr. Dule has taken it at Lewell, Dorset.

S. saltatoria, Limn. (var. vestitr, D. S. S.; marginellu, D. S.S.; fucicola, D.S.S.).-Oval, black, clothed with short golden pubescence, elytra with pale spots, sides of pronotum rounded. Head with the mouth parts pale; au- 
tenne with the first and second joints more or less pale; pronotum with the sides slightly rounded, widely depressed, base broadly sinuate across the scutellum; disc with a transverse impression, raised in front of it, with a small fovea in the elevation; scutellum black; elytra black, with numerous small yellow and whitish spots, varying considerably in their size and colour; legs pale, femora with a black line beneath; anterior tibiw black at the extreme base and apex, with a cloudy or brownish mark in the middle, other tibix black at the extreme base and apex; all the tarsi black at the apex.

L. $3-4 \mathrm{~mm}$.

Generally distributed in moist places by the sides of ponds, on heaths, etc.; a more inland species than the following, and in some localities very abundant. In the var. vestita the vestiture of golden hairs is much denser than in the typical form. This variety has only been recorded from seotland and the Tyueside district.

S. pallipes, Fab. (var. palustris, Dougl.).-Differs from the preceding only in the style of the markings; those of the elytra are larger and less numerous, and tend to spread much more than in saltatoria; often, or perhaps generally, the whole of the elytra, except the clavus, the base of the corium, and a few lateral spots, is pale. An apparently constant character has been pointed out by Dr. Reuter, viz. the entire black line which runs down the anterior tibixe from the base to beyond the middle. In sultatoria the line is indicated only at the base, in the centre, and at the apex. This seems a poor character, but it certainly appears to be constant, and to separato the two species in accordance with the style of the elytral markings.

L. 3-4 $\mathrm{mm}$.

Very common, and generally distributed in salt marshes, etc.

S. pilosella, Thoms.-Very much like the pale form of

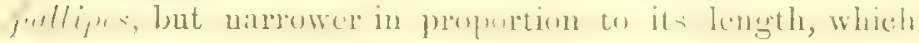
slightly cxeceds that of pallipes. It way be known from 
that species at once by the longer hairs on the first and second joints of the antennar, and the semi-erect hairs which ) clothe its upper surface; the eyes also are smaller and rather farther apart, and the pronotum rather more conver and raised posteriorly ; tho dark lines on the front tibix are very strougly marked.

L. $4 \mathrm{~mm}$.

I have considered this in my last Catalogue as a pilose state of pallipes; but at Mr. Edwards's suggestion I have re-examined the matter, and I think I was wrong. The character of the smaller eyes seems to me to be an important one, which had escaped my notice till I re-examined them lately; at any rate, it is a form easily distinguished by its hairy upper surface.

Less common than pullipes, but often occurring with it.

Deal, Hastings, Worthing, Southwold; Salthouse, Cley, Norfolk, Filuarls; St. Leonards, Rye, Jiutler; Hunstanton, Fowler; Bristol, Lymington, Blatch; Mumby Chapel, Lincolnshire, J. E. Mason; Gravesend, Margate, Billups.

S. arenicola, Silwltw-O Of a decper black than either of the precediug species, although similar in form, and possibly only a colour variety of pallipes. It may bo easily known by the pale white markings of the elytra, which, against the deep black ground colour, are peculiarly conspicuous. They consist of a small spot at the apex of the clavus, a broad transverse band across the centre of the corium and several small spots below it; two side by side near the outer apical angle forming another short band. These markings vary to a certain extent, but the central band seems to be very constant; membrane dark smoky, sometimes unspotted, at other times with the cells pale, with a central oval black spot in each; nervures black, a spot near the apex of the corium and the apical margin pale, a black spot on each side between them; legs pale; tibire outwardly, except a band just above the apex, black; tarsi witl the apices of the joints black. 
L. 3-4 $\mathrm{mm}$.

Rare. Bournemouth, Shiere, Camron; Portsmouth, Moncreaff; Isle of Wight.

S. Cocksii, Curt. (elegantula, D. \& S.).-Head black, shining, with scattered long hairs, eyes very large and prominent, ocelli contiguous, antenna pilose, with the first and second joints pale whitish, black at the base, third and fourth considerably thickened, black; pronotum black, shining, constricted in front into a narrow collar, then produced at each side into a very slight angle, behind which the sides are sinuate and then diverge in nearly straight lines to the base, which is about twice the width of the anterior margin and largely sinuate; disc clothed with long bristly hairs, deeply impressed across the middle and strongly raised in front of the impression, with a small forea in the elevation; scutellum black, shining, clothed like the pronotum and elytra with long bristly hairs; elytra black, dull, the rounded, reflexed lateral margins and the inner margin of the clavus, shining, disc with a few greyish spots and a conspicuous white round spot near the apical margin of the corium, lateral margins pale yellow, broadly so at the base and apes of the corium, the pale colour almost or quite interrupted behind the middle; membrane usually very short, dark, nervures black; legs yellow, apices of tibia and tarsi black.

L. $3-3 \frac{1}{2} \mathrm{~mm}$.

In Sphagnum; Woking, Chobham, not rare; Fens, Norfolk, Eduards; Knowle, Bewdley, Coleshill, Cannock Chase, Church Stretton, New Forest, Blatch; Gumley, Lincolnshire, W. W. Fowler; West Ham Marshes, Carphilly Castle, South Wales, Billups; Battle, Frant, Fritton Suffolk, Butler; Glanvilles Woottou, Dale.

S. elegantula, Fall. (Flori, Dolmm.).-Almost identical in shape and colour with the preceding, but differing notably in the antenna, which have the first joint pale only at the apex, the second entirely black, and the third and fourth black, not wider than the second, the fourth sometimes 
with a yellow spot; the yellow of the lateral margins of the corium spreads rather more on to the disc of the elytra, and the memurane has a yellow patch behind the apex of the corium not observable in Coclivib.

L. $3-3 \frac{1}{2} \mathrm{~mm}$.

Hammersmith, Power; Wicken Fen, Blatch.

S. cincta, II. Schff.-Rather longer than either of the preceding, with the membraue more developed, upper surlice glabrous or nearly so. Antenna filiform, entirely black except the apex of the basal joint, second joint much longer than in Coelswii or eleyantula; pronotum shaped much as in those species, but wider behind in proportion to the anterior margin, anterior callosity not so strongly developed; elytra longer and more parallel-sided, disc more spotted, lateral margins black at the base, then narrowly yellow to the apex, where the colour sometimes spreads; it is also sometimes interrupted by a black spot behind the midale; there is a similar conspicuous white spot near the apex of tho corium as in the preceding species; membrane yellowish, its base, apex, nervures, and a spot in each cell, dusky; legrs brownisld ochreous.

L. $3-3 \frac{1}{2} \mathrm{~mm}$.

Reigate, Chobham; Redhill, Linnell; Mumby Chapel, Lincolnshire, J. L. Mason; Leicester, Marshall; Armagh, Johnson; Fens, Norfolk, Edwards; Canning and Rainham, Billups; Shalford, Butler; Knowle, Coleshill, Sutton Coldfield, Bewdley, Cannock Chase, Blatch; Repton, Fouler; Norayshire, Forres, Norman; Haliday Collection; Laud's End, Dale; Brackish Marsh, Moreton, Cheshire, J. W. Ellis.

\section{CIMICID正.}

This family is composed chiefly of small species, but in. cludes the most widely-known member of the order, viz. the common bed bug, (imex lectularins, Lin. The chief characteristic of the finmily lies in the narrowly produced face 
extending horizontally, far beyond the base of the antennæ, the sides of which tend to be parallel more than in most of the families. Another characteristic of the family is the presence of the embolium, a narrow piece on the outside of the corium separated off from the disc by a distinct suture. The antenno are four-jointed, and the third and fourth joints are in some genera much narrower than the other two. In the Ceratocombina the first and second joints together are not half so long as the third and fourth; in Triphleps the antenux are thicker in the $\delta$ than in the $o$. The ocelli are present in all the genera except Cimex, although not always conspicuous in the brachypterous forms. The rostrum is three or four-jointed and free except in Cimex, where it is received into a groove under the head; the pronotum is gemerally trapeziform in shape, varying considerably in its length and width. In Cimex a different form occurs, the sides being reflexed and widest in front; in the brachypterous females of the Microphysina also the trapeziform shape is not always maintained. 'The scutellum is exposed throughout the family; the elytra vary much in form, in Cimes they are always rudimentary, in Cerutocombus they cover the abdomen, but are very rarely fully developed, i.e. they are destitute of a membrane; in the Microphysina the only has the elytra developed, those of the of being very short and rudimentary; the abdomen has the connexivum hidden by the elytra. Dr. Reuter says of the genital segments of the males in the Antrocorina and Mycrophysina, that the genital aperture is asymmetrical and placed on the left side of the segment; legs simple, anterior femora incrassated in Piezostethus; tarsi two or threejointed. 'The specios of this family exist on animal or vegetable juices.

TABLE OF SUBFAMILIES.

(ii) 1. Rostrum three-jointed, tarsi three-jointed.

(ii) 2. Ocelli absent . . CImicina.

(2) 3. Ocelli present. 
(5) 4. Antennx very long and thin, clothed with long hairs, third and fourth joints together twice as long as the first and second.

(4) 5. Antenna not very thin, not clothed with

Ceratocomina. long liairs, and third and fourth joints not nearly twice as long as the first and second. . . . Anthocorina.

(1) 6. Rostrum four-jointed, tarsi two-jointed - Mickophysina.

\section{CIMICINA.}

\section{CIMEX, Lin。}

Of this genus we have four British species, which may be known at once from those of any other genus by their flat, broad, oval form; the absence of ocelli; the broad, truncate central lobe of the face, the short, scale-like elytra, and the reflexed margined pronotum, whose greatest width is in front, and whose anterior margin is very deeply sinuate; rostrum short, reaching to about the anterior coxn, received in repose into a groove on the underside of the head; antenne with the third and fourth joints much thinner than the first and second and filiform; legs simple, tarsi three-jointed; mesosternum with a trapeziform plate, the wide end of which projects over the metasternum between the posterior coxi.

(4) 1. Clothed with short hairs, sides of pronotum widely dilated and reflexed, especially in front.

(3) 2. Larger, fourth joint of antenne two-thirds as long as third. . . . . LECTULARIUS,

(2) 3. Smaller, fourth joint of intenno threefourths as long as third. . . . columbarius.

(1) 4. Clothed with loug hairs, sides of pronotum narrowly reflesed.

(6) 5. Larger, clothed with silky hairs, third joint

of antenna longer than fourth
(5) 6. Smaller, clothed with somerwat bristly hairs,
third and fourth antennal joints subequal.

PIYISTRELLI.

C. lectularius, Lin-Entirely of a reddish brown or brownish yellow colour, closely and deeply punctured, sparingly clothed with short, pale hairs. Head with the 
eyes prominent, antenux with the first joint short and thick, the second and third subequal in length, the fourth about two-thirds as long as the third, the third and fourth very thin and clothed with long, fine hairs; pronotum with the anterior margin very deeply sinuate so as to receive the head nearly to the eyes, its sides rounded, dilated and reflexed, especially in front, and fringed with short hairs, base slightly sinuate, dise somewhat shining, very slightly convex longitudinally; scutellum very short and transverse; elytra in one piece, truncato posteriorly, twice as wide as long, about as long as the first abdominal segment, very largely punctured; abdomen short, oval, flat, more finely punctured than the elytra; connexivum narrowly reflexed; legs slightly paler than the rest of the body.

L. $5-6 \mathrm{~mm}$.

Too common in dirty houses, especially in large towns.

C. columbarius, Jen.-Very like the preceding, but rather smaller, the third and fourth joints of the antennæ distinctly thicker and their pilosity not so long, the fourth being nearly three-fourths the length of the third; the second joint is also more thickened to the apex; the pronotum is more transverse and wider in proportion to the abdomen, and the sides of the latter diverge more rapidly from the base.

L. $4 \frac{1}{2}-5 \mathrm{~mm}$.

In pigeon cots. Alford, Lincolnshire, abundant, J. $E$. Mason.

C. hirundinis, Jen.-Smaller than either of the preceding, with much longer pubescence and quite different in the shape of the pronotum and head. Pale testaceous or brown, eyes not prominent, central lobe of the face less narrowed posteriorly, antenu» with the third and fourth joints subequal ; pronotum with the anterior margin nearly straight in the middle, produced at the angles, which touch or almost touch the ejes, sides narrowly reflexed through- 
out, fringed with long pale hairs, base straight; elytra very largely punctured; abdomen much more finely so; legs paler.

L. 3-4 mm.

In martins' nests; rare. I once took a good series in the windows of a house at Chobham over which a martin had a nest. "Swarming in martins' nests in Cambridgeshire," Jenyns; Tuubridge Wells, Curtis; Stoke Holy Cross, Norfolk, Edwards"; dead swallow, Armagb, Johnson.

C. pipistrelli, Jen.-About the size of columbarius, but longer and more attenuated posteriorly, and with very long pubescence; antenna with the third joint longer than the second, the second longer than the fourth. Head shaped much as in colunbarius; pronotum with the anterior margin very deeply sinuate, largely produced at the angles, sides rounded, narrowly and evenly reflexed throughout, fringed with long hairs; elytra strongly punctured; abdomen more clongate and pointed behind than in any of the preceding, clothed with rather conspicuous, long, pale hairs.

L. $4 \frac{1}{2}-5 \mathrm{~mm}$.

Bats. Lversley, Croteh; Cambridgeshire, Jenyns; Norfolk, Lord Wulsingham; Dorsetshire, Pichard Cambridge.

\section{CERATOCOMBINA.}

(2) 1. Pronotum convex, subeylindrical . Ceratocondus,

(1) I'. Ironotum flat, widely transverse - Chiptostemis.

\section{CERATOCOMBUS, Sign.}

There is ouly one known representative of this little genus, which occurs in moss, dead leaves, etc. It is extremely fragile, and might be passed for a very small tly, as its movements are very active. Head convex, eyes very far apart, the ocelli placed close to their inner margin; antenna with their first and second joints stout, the third 
longer than the first and second together, fourth subequal to the third, third and fourth very thin, clothed with long hairs; pronotum convex, nearly square, sides subparallel, straight; scutellum triangular, its sides and baso about equal; elytra very rarely developed; in the undeveloped form each consists of a convex simple sheath covering the abdomen, nerves apparent towards the apex, lateral margins reflexed at the base; in the developed form the elytra are widened behind, the clavus is distinctly marked, and there appears to be a somewhat distinct membrane; my only knowledge of this form is from the figure given by Reuter, Not. Sällsk. Faun. et Flora Fenn. xi, pl. i. fig. 7. Leg's with the anterior coxa very large, tibia rather stout, tarsi three-jointed.

C. coleoptratus, Zett. (nuscornm, D. \& S.).-Brown, subelongate, with long, very remote hairs on the head and pronotum, antenns and legs paler; the former with very long erect hairs; pronotum in front slightly narrower than the head across the eyes, slightly widened posterinly, sides straight, base widely and shallowly sinuate; scutellum simple; elytra covering the abdomen; legs simple, anterior tibiæ slightly dilated.

L. $1_{2} \mathrm{~mm}$.

Moss and dead leaves, Chobham; Weybridge, Power; Claremont, Billups; Norfolk, Ldwards; Matlock, under bark, Blatch; York, Beaumont; Hurst Green, Battle, Bexhill, "in moss under heath," Butler" Forres, Norman; Wisher, Bexley, Champion.

\section{CRYPTOSTEMMA, $I$. Schf.}

$$
\text { (Dipsocoris, D. \& S.) }
$$

Of a vory thin and delicate structure, clothed with fine silky hairs. Nearly flat, head transverse; eyes very remote; ocelli very small, placed close to the eyes; antenna with the first and second joint short and thick, third and fourth 
very long and thin, clothed with fine hairs; pronotum very transverse, trapezoidal, its margins nearly straight; scutellum triangular, transverse; elytra long, extending far beyond the apex of the abdomen, largely rounded posteriorly; membrane very large; legss simple, tarsi threejointed.

There are two European species, of which we have only one in this country.

C. alienum, $I I$. Sff.-Dull, pale groyish-brown, third joint of the antenne about twice as long as the first and second together, fourth about three-quarters as long as the third; pronotum at the basenearly twice as broad as long, and once and a half as broad as the anterior margin, sides and anterior margin nearly straight, base very slightly sinuate; elytra slightly shining, very thin, their lateral margins reflexed at the base; membrane rather thinner, and more transparent than the rest of the elytra, but of much the same colour; tibire with a few fine bristly hairs.

L. $2 \mathrm{~mm}$.

On the edges of streams in summer; near Black Lakes, Kerry, Ireland, Haliday; Bettws-y-Coed; Irybridge, South Devon, Wollaston; Banks of the Almond, near Edinburgh, Sharp; Bewdley, Ludlow, Church Stretton, Blatch; Barry Island, South Wales, Billups; Forres, Perth, Reuter.

\section{ANTHOCORINA.}

(4) 1. Third and fourth joints of the antenne very fine and thin, clothed with long erect hairs.

(3) 2. Anterior femora hardly thicker than the intermediate pair. . . . Lrctocoris.

(2) 3. Anterior femora incrassated, much thicker than the intermediate pair . Prezosteruls.

(1) 4. 'l'bird and fourth joints of the antenua scarcely or not thinner than the preceding, hairs not long and erect. 
(16) 5. Cell of the wing with a hook-like nerve.

(15) 6. Pronotum with a distinct apical collar.

(10) 7. Apex of the metasternum between the coxæ widely truncate.

(9) 8. Rostrum reaching to the intermediate coxis . .

(8) 9. Rastrum not reaching beyond the centre of the mesothorax. . .

(7) 10. Apex of metasternum rounded and narrowel.

(14) 11. Rostrum short, hardly reaching bejond the anterior coxie.

(13) 12. Apical collar of pronotum long, sides gradually diverging from it.

(12) 13. Apical collar short, sides widely rounded behind it

(11) 14. Rostrum reaching to the intermediate

COxæ . . ACOMPOCORIS.

(6) 15. Pronotum without a distinct collar: TRIPeLEPS.

(5) 16. Cell of the wing twithout a hook-like

Temnostethes.

Elatophilus.

ANTHOCORIS.

Tetrapileps, nerve.

(20) 17. Species robust, pubescent.

(19) 18. Head short, scarcely longer than its width between the eyes

(18) 19. Head much longer than its width between the eyes . . . . Cardiastetirus.

(17) 20. Species elongate, glabrous, parallel-sided XYLoconIs.

\section{LYCTOCORIS, Hahn.}

There is only one species of this genus, which may be known by the following cliaracters. Head across the eyes as wide as long, narrower than the front of the pronotum; ocelli situated near the inner margins of the eyes; antenna with the first joint short, reaching to about the apex of the face, second thickened towards the apex, third and fourth subequal, very thin and pilose; rostrum long, reaching to the apex of the metasternum; pronotum subtrapeziform, with its anterior margin sinuate, base sinuate; scutellum large, impressed in the centre; elytra broad and flat, nervures of the membrane very feebly indicated; legs simple.

L. campestris, $F a b$. (domesticus, D. \&. S.).-Testaceous brown, dull, base of the elytra and a spot near the apex 
paler, membrane smoky white. Head punctured across the centre; pronotum with the sides widely rounded, narrowly reflesed, more distinctly so in front, disc with a shallow transverse impression, finely punctured behind it; scutellum shining, finely punctured at the base, transversely wrinkled at the apex; elytra finely and rather closely punctured, pale at the base, brown on the apical half, generally with a small palo spot near the base of tho cuners inwardly; legs pale ochreous.

L. $3 \frac{1}{2} \mathrm{~mm}$.

Common and generally distributed; often fond in houses, haystack rubbish, under bark, etc. It is able to give a distinct and painful bite.

\section{PIEZOSTETHUS, Ficb.}

Head rather elongate, face truncate in front; ocelli situated between the eyes posteriorly; eyes slightly prominent, rather large; antenna with the first and second joints thick, third and fourth very thin, and clothed with long erect hairs; pronotum trapezoilal, smootl, shining: convex in front, sides not impressed, and not margined; scutellum smooth, impressed in the middle; elytra somewhat shining, membrane shining, nervures scarcely visible; legs with the front femora incrassated, especially in the $\sigma$.

There are fifteen species given in Dr. Puton's Catalogue, of which we have three in this country. One of these, formicutorum, Boh., inhabits ants' vests. Dr. Reuter has pointed out excellent characters in the form, length, etc., of the canal of the odoriforous sac.

(4) 1. Jarger, 2-20 $\frac{1}{2} \mathrm{~mm}$.

(3) 2. Elytra always developed, pale whitish, canal of the odoriferous sac almost proAuced to the mesosternmm - - GALACTINUs.

(2) 3. Elytra sometimes abbreviated, testaceous or brownish, canal of odoriferous sac terminating at some distance from the mesosternum . . . .

(1) A. Stualler, $1 \frac{1}{3} \mathrm{~mm}$. : : : : rormicetortar. 
P. galactinus, Fieb.-Head and pronotum black, very shining, with a few very remote, long, erect, fine hairs; antenna piccous, second joint at the apex, and third and fourth darker, these latter much thinner than the second, each about three-quarters its length; pronotum at the base about once and a half as broad as long, with the sides rounded in front, thence very slightly sinuate to the posterior angles, base shallowly sinuate, dise very shining and polished in front, slightly depressed and punctured behind; scutellum very shining, the apical half depressed, and the extreme apex transversely rugose; elytra yellowishwhite, somewhat dull, and vory shallowly and finely punctured, and clothed with exceedingly short pale pubescence; membrane milky-white, shining; legs testaceous, the femora darker, tibiæ with rather long bristles; canal of the odoriferous sac very long and curved, almost reaching to the apex of the mesosternum.

L. $2 \frac{1}{2}-2 \frac{3}{2} \mathrm{~mm}$.

Often found commonly in hot-beds, etc., Reigate, Woking; Bath, Blathwayt; Bishops Teignton, Devon, Marshall; Ewhurst, Butler; Edgbaston, Knowle, Blatch; Canning Town, Dulwich, and Cardiff, Billups; Glanvilles Wootton, Dale.

P. cursitans, Fall.-Rather smaller than galactinus, and proportionately wider; pronotum distinctly shorter and wider, more rounded in front behind the anterior collar; the elytra are darker, and more distinctly pubescent, the whole of the embolium and cuneus, and the clavus and apex of the corium more or less pitchy brown, and more strongly punctured; in the undeveloped form the elytra are short and testaceous, not quite twice as long as the scutellum, round at their apices; legs testaceous, the femora pitchy brown, tibire spinose; canal of the odoriferous sac rather more abruptly angulated than in galactinus, and abbreviated, so that it does not extend nearly so far as the margin of the mesosternum. 
L. $2-2 \frac{1}{2} \mathrm{~mm}$.

Under bark, Reigate; Knowle, Bewdley Forest, Needwood Forest, Sherwood Forest, Eilatch; Milford, ITarshall; Devon, Parfitt; East Grinstead, Loughton, Champion; Glanvilles Wootton, Dale; Headley Lane, Chobham, Weybridge, Billups.

P. formicetorum, Boh.-Much smaller than either of the preceding, and one of our smallest Hemiptera, shaped something like cursituns, but with the head wider and the eyes less prominent; pronotum wider in front, its apical margin about three-fifths the length of the base, sides slightly rounded; elytra dull ochreous, finely pubescent, puncturation very fine and shallow; legs pale ochreous, the femora slightly darker.

L. $1 \frac{1}{2} \mathrm{~mm}$.

In nests of Formica rufa, Braemar, $F$. B. White.

\section{TEMNOSTETHUS, Fiel.}

Head and pronotum dull, the former not quite twice as long as the forehead between the eyes; ocelli placed just behind the eyes, in a line with their inner margins, eyes situated at some distance from the pronotal margin; head, behind them, slightly narrowed; antenuse with the second joint almost as long as the third and fourth together; rostrum long, reaching to the intermediate coxis; pronotum with a narrow anterior collar, sides carinated, rounded thence in very divergent lines to the posterior angles, base deeply and widely sinuate; scutellum impressed towards the apex; elytra sometimes developed, sometimes abbreviated; in the developed form with the menbrane complete, extending beyond the apex of the abdomen; in the undeveloped the elytra are scarcely more than twice as long as the scutellum; legs simple, tibice not spinose; canal of the odoriferous sac straight.

There is only one species in the genus.

T. pusillus, II. Schff.-Head and pronotum black, the 
latter clothed with short pale semi-adpressed hairs ; antenna with the second joint often pale in the middle, or in the brachypterous form entirely pale, except at the extreme base and apex; pronotum with a well-defined anterior collar, whence the sides are rounded and narrowly reflexed, posteriorly they are simply carinated, base widely and deeply sinuate, disc with a curved transverse central impression, the base behind it transversely rugose; scutellum black, finely punctured, with a few transverse lines near the apex; elytra bromnish-black, clavus and corium inwardly paler, sides of the corium reflexed, a triangular spot at the base and a small transverse spot just above the cuneus whitish: in the undeveloped form with only the triangular basal spot; the membrane in the developed form is dusky, with the base and a spot below the apex of the cuneus hyaline; legs, femora black, tibiæ and tarsi testaceous.

L. $3 \mathrm{~mm}$.

Generally distributed and common on oak and other trees.

ELATOPHILUS, Reut.

Differs from Temnostethus in the longer head, which is more than twice as long as its width between the eyes, longer and more swollen behind the eyes, and more suddenly constricted behind the swelling; rostrum shorter, reaching only to the middle of the mesosternum; pronotum at the sides with scarcely any apical constriction, base very shallowly and widely sinuate; elytra always complete; canal of the odoriferous sac long, bent at nearly right angles, and almost reaching the apex of the mesosternum.

We have only one out of the five Palacarctic species.

E. nigricornis, Zett.-Head and pronotum black, shining; face narrowed in front; antennæ entirely black, first joint hardly extending to the apex of the face, second joint as long as the third and fourth together; pronotum

o 2 
very narrow in front, the apical margin hardly more than one-third as Jong as the base, sides very narrowly reflexed in front, and diverging in nearly straight lines till just above the level of the transverse callosity, where they are very slightly angulated, and thence diverge less rapidly in rather sinuate lines to the posterior angles, base very shallowly sinuate, disc with a deep transverse impression near the base, and a strongly-raised elevation in front of it; scutellum black, shining at the base, shightly impressed towards the apex, where it is transversely wrinkled, and dull; elytra ochreous-brown, slightly darker at the sides and apex; membrane dusky, pale at the base; legs with the femora black-brown, tibire and tarsi testaccous.

L. $3 \frac{1}{2} \mathrm{~mm}$.

Perth, Hill of Moncrieff, Reuter; also taken at Forres by $M r \cdot G$. Norman.

\section{ANTHOCORIS, Fall.}

This genus is composed of numerous very closely allied species; Dr. Puton gives thirteen in his Catalogue, of which six havo been recorded from this country. The specific characters lie chietly in the nature of the surface of the various parts of the elytra, as pointed out by Dr. Reuter; these characters, although "critical," seem to be well maintained in the different species. Whe following characters will distinguish the genus from its allies. Head with the eyes not touching the pronotum; ocelli placed posteriorly, close to the imner margins of the eyes; antenua with the second joint not nearly so long as the third and fourth together; rostrum short, reaching to about the anterior coxw; pronotum with a well-marked apical collar, sides behind it more or less rounded, base largely sinuate; scutellum impressed at the apex; elytra always developed, their sides subparallel or slightly rounded; legs simple, posterior coxx close together, the metasternum produced 
between them in a narrowly rounded lobe. The species often prey on Aplicles.

(9) 1. Elytra in part dull.

(3) 2. Corium entirely shining, except at the extreme lase . SAROTIAMN.

(2) 3. Corium dull, except towards the

(2) 4. Corium entirely duil.

(6) 5. Cuneus entirely shining . . Nesroratis.

(5) 6. Inner angle of cuneus dull.

(s) 7. Larger, head and pronotum black . conrosus.

(7) 8. Smaller, head and pronotum in front red . . . . VISCI.

(1) 9. Elytra enturely shining . . SYLVESTRIS.

A. confusus, Ricut.-Head and pronotum black, shining; the latter sometimes pitchy at the posterior angles; face truncate in front; antennw tinely pilose, with the basal joint extending to about the apex of the face, second joint pale in the centre, uearly twico as long as the first, fourth rather longer than the third, third and first subequal; pronotum with a well-detined apical constriction, the sides behind it suddenly diverging and rounded, thence nearly straight to the posterior angles, base sinuate; disc with a deep transverse impression behind the middle, in front of which is a rounded transverse elevation, which is smoother than the base and apical constriction, these latter being indefinitely punctured; scutellum black, shining, impressed at the apex, indefinitely punctured; elytra dull brown, finely punctured and pubescent, very slightly paler near. the base of the corium and at the inner apical angle of the embolium; embolium and outer two-thirds of the cuneus shining, pitchy-brown, and more strongly punctured; inuer third of cuseus within the central nervure dull ; membrane dusky, with a pale spot on each side, and the base white, the three spots sometimes united; legs pitchy-brown, tibia and tarsi rather lighter in colour than the femora.

L. $4 \mathrm{~mm}$.

Norfolk, Elwards; Bakewell, Woking, Bromley, Ilfrat- 
combe; Darenth, Nickleham, Aviemore, Champion; Colwyn Bay, Beumont. No doubt common and generally distributed, bat mixed in collcetions with the following.

A. nemoralis, Fubr.-Very like confusus, but broader, more brightly coloured, and much more variable in colour, the pronotum posteriorly often pale, the clavus partly pale and partly dark, the base of the corium generally widely pale and the apex dark, the pale colour paler than in confusus, the dark darker. 'There is also a fine grey or hoary pubescence on the corium, visible in certain lights, which seems peculian to this species; the cuners and embolium are entirely shining, pitchy, and strongly punetured, and Dr. Reuter says that the inner veins of the membrane are more distinet.

L. $4 \mathrm{~mm}$.

Very common and generally distributed on various trees aud shrubs.

A. gallarum ulmi, De Gecr-A species very closely allied to tho two preceling, but casily distinguished when once recognized; as a rule it is larger and broader; the elytra lave the clavas and corium almost of one colour, paler and slightly brighter than in confusus, becoming darker towards the apex, the entire cmbolium and cuneus are shining, but less bright and less strongly punctured than in nemoralis; the apex of the corium also, instead of being quite dull as in both the preceding, is somewhat shining; the antenna are sometimes entirely black, but in the typical form have the second joint pale in the centre; legs testaceous.

L. $4 \frac{1}{2} \mathrm{~mm}$.

I have one specimerz from near Gomshall, and another from Chobham, which clearly belong to this species; aud I have three others, one from Woking, and two from Bakewell, Derbyshire, which appear to me to be only varieties of it; they are, however, smaller and more brightly coloured; the antennæ in three of these are entirely black, 
possibly they may be referable to Minki, Dohm, as one has the head red, although quite mature; but $I$ much doult if Minki is more than a small variety of the above. Since writing this I lave seen three of the black antenna'd form: two from Mickleham, and one from Caterham, taken by Mr. Champion. This also is doubtless mixed in collections with nemoralis.

A. visci, Dougl.-A very much smaller species than any of the preceding, though structurally allied to nemoralis and confusus. Head and pronotum ferruginous; the latter black, or darker at the base; antenue ferruginous, the apex of the second joint and the third and fourth dusky, second joint as long as the third and fourth together; scutellum pitchy black; elytra ferruginous, the apex of the clavus and corium dark, a pale spot near the inner apical angle of the embolium; embolium posteriorly and cuneus externally pitchy brown, shining, and strongly punctured; membrave with a spot on each side, and often one at the base, white; legs pale testaceous (posterior tibix in one specimen dark towards the base).

L. $2 \frac{3}{4} \mathrm{~mm}$.

Off mistletoe, Hereford, Dr. Charmun.

A. sarothamni, D. \&. S.-Distinguishable from any of the preceding by its dark colour and brighter surface; the antenna are quite black, and the legs also in mature examples, the corium entirely bright and shining, except at the extreme base; this last is its most important character, by which it may be kuown at once; the clavus is quite dull as in all the preceding; in size it is rather smaller than nemoralis.

L. $3-3 \frac{1}{2} \mathrm{~mm}$.

On common broom, Woking, Chobham; Weybridge, Douglas and Scott; Guestling, Collett; Shirley, Lee, Billups; Perth, liouter.

A. sylvestris, Linn. (nemorum, Linn. et anct.).-Quito distinct from any of the preceding, entirely smooth and 
shining. Antenne long and slender, much longer than the head and thorax together, basal joint black, or sometimes pale, second and third pale testaceous, more or less black at the apex, fourth black. Dr. Reuter says that the antennæe are sometimes entirely black, head and pronotum black, the latter sometimes paler posteriorly, shining, its sides finely marginate, slightly rounded behind the apical collar and then subsinuate, base rather deeply sinuate; trausverse callosity behind the collar smooth and shining, transverse impression punctured and wrinkled; scutellum black; elytra entirely shining, pale, whitish testaceous, the clavus generally rather darker, puncturation very indefinite and shallow, a cloud at the apez of the clavus, a spot near the apex of the corium, and the cuneus more or less dark, the dark colour sometimes only apical; membrane white, dusky on the disc, and again at the apex; legs pale testaceous, posterior femora sometimes with an apical ring.

L. $4 \mathrm{~mm}$.

Very common and generally distributed on various trees and shrubs.

\section{TETRAPHLEPS, Fieb.}

Nenrly allied to Anthocoris, but easily distinguished by its shorter pronotum, whose much shorter apical constriction gives a groater appearance of width in front; the cuneus also is wider and much longer, and the surface of the elytra is strongly punctured; the canal of the odoriferous sac is much narrower, and less open; rostrum short, only reaching to or just beyond the anterior coxa. We have only one British species out of the two recorded as Palæarctic.

T. vittata, Ficb.-Flat, dull brown, head, pronotum and scutellum black. Face in front of the eyes very narrow, its sides slightly sinuate; antenux finely pilose, black, first joint short, not quite reaching the apex of the head, second piceous, third and fourth subequal; pronotum 
clothed with short pale hairs, with a very narrow anterior collar, the sides behind it much rounded and sharply reflexed, gradually diverging to the posterior angles, where they are simple, the reflection ceasing just beyond the middle, base largely sinuate, disc with a shallow transverse impression, posteriorly slightly wrinkled and punctured; scutellum punctured; elytra brown, punctured; embolium and cuneus outwardly sometimes darker; cuneus in the $f$ nearly as loug as the corium; membrane dusky, with four longitudinal pale streaks; leg's testaceous brown, femora darker towards the base.

L. $3 \frac{1}{2} \mathrm{~mm}$.

Not rare on fir trees, especially larches, Bromley, Wolking, Reigate; Darenth Wood, Mickleham, Billups; Norfolk, Edwards; Lincolnshire, J.E. Mlason; Stevenage, Wymondley, Ewhurst, Butler.

\section{ACOMPOCORIS, Reut.}

Very closely allied to Tetraphleps, but recognizable by its louger rostrum, which reaches to the intermediate cosæ, by the sides of the pronotum anteriorly being scarcely reflexed, and by the rather longer first joint of the antennw, which just reaches the apex of the cheeks; according to Reuter, the canal of the odoriferous sac is curved forwards at the apex instead of backwards. We have both the Palæarctic species recorded from this country.

(2) 1. Paler, apical joint of antenno distinctly longer than the third. . . PYGMECS.

(1) 2. Darker, third and fourth joints of antenna subequal. . . . . . ALPINUs.

A. pygmæus, Fall.-Head, pronotum, and scutellum black; elytra and legs testaceous or ochreous. Head about as loug as wide across the eyes, antenna with the second joint pale except sometimes at the base and apex, third distinctly longer than the fourth, sometimes palo at the base; pronotum with a narrow apical collar, though not so 
narrow as in Tetrimhlops, sides behind it rounded, but only very narrowly reflexed quite near the anterior augles, base sinuate, disc punctured and clothed ivith fine pale hairs, having a bright smooth elevation in front of the transverse impression; scutellum punctured; elytra punctured, clothed with adpressed pale hairs, membrane pale smoky-yellowish; legs pale testaceous.

L. 3 mm.

Common on fir trees, and generally distributed.

A. alpinus, Iieut-Very like a narrow, dark form of the preceding, but the mombrave in the of is longer and the whole insect larger, darker, and more elongate. 'The $q$ is more difficult to separate, but it is darker, and the elytra are less distinctly punctured, although, if anything, more coarsely so. In doubtful cases, however, I belicve the antennal characters will always decide the question; in this species the third and fourth joints are subequal, whereas in mygnous the fourth is distinctly shorter than the third.

L. $3{ }_{2}^{1}-4 \mathrm{~mm}$.

Norwich, Dossetor; Forres, Norman; Esher, Champion; Hurst Green, Battle, Butler.

\section{TRIPHLEPS, Fieb.}

Of this little genus wo have three ont of the eleven species recorded by Dr. Puton in his Catalogue. All the species are closely allied, but can bo separated satisfactorily after careful examination. 'The genus is quite distinct from any of its allies by its small size and broad form; in these it approaches nearer to Brachysteles and Cardiustethus, which, however, waut the hook-like nerve in the wing cell, which is present here.

Head short, first joint of the antenna reaching to about the apex of the head, third and fourth subequal; in one species, nigra, Wolti., the antennw are considerably thickened in the $\delta$, in the others they are only slightly thicker than 
in the of ; rostrum renching to the anterior coxa; pronotum much widened posteriorly, its sides rounded, anterior margin with a scarcely perceptible collar; olytra punctured, membrane complete in all our species; legs simple; canal of the odoriferous sac very long and curred towards the apex. I have largely drawn from Dr. Reuter's worlss for the characters of the species.

(2) 1. Hind tibix black or piceous . . . NIGEr.

(1) 2. Hind tibire pale ochreous.

(4) 3. Larger, head as long as wide, pronotum in

front not half as wide as at the base - arasusculus.

(3) 4. Smaller, head transverse, pronotum in front more than half as wide as at the base Mrrvurus.

T. niger, Wolff - Black, shining, elytra more or less pale. Head much wider than long, antennse pilose, in the ot much thickened and somewhat flattened, second joint thicker than the third and fourth, pale, third about as long as the fourth, fourth often pale; in the $q$ the antenno are scarcely thickened and are pale except the basal joint; pronotum black, anterior margin more than half as long as the base, sides nearly straight, narrowly reflexed in the of, disc shining, clothed with fine short hairs, with a transverse shining callosity in front, rugosely punctured across the base; scutellum shining, punctured; elytra rather strongly punctured, ochreous in the $\delta^{*}$, with the cuneus and sometimes the apex of the corium darker, in the of very variable in colour, sometimes quite black, sometimes as in the 8 ; legs pitchy, anterior tibia and apex of the anterior femora pale.

L. $11 \mathrm{l}-2 \mathrm{~mm}$.

Common. I have taken it generally in heathy places; Chobham, Woking, I'unbridge Wells, Southwold, Herne Bay, Ilfracombe; Bournemouth, Chesil Beach, Dale; Norfolk, Eutwards; Battle, Butler; Oxshott, Billups.

T. majusculus, lient.-Much larger tban the preceding, with which it cannot well be coufounded, the thinner anteume and pale tibir distinguishing it at once. 
Head black, sbining, as wide as long, antenux pale, the third and fourth joints dusky, second joint in tho malo thickened and about as long as the head, third and fourth joints thinner, subequal, second joint in the $q$ not thickened, shorter than in the $\delta$, about as long as from the apex of the head to the ocelli; pronotum black, shining, strongly punctured posteriorly, anterior margin not half so long as the base, sides nearly straight, margins narrowly reflexed in the of nearly or quite up to the posterior angles, in the o carinated, but hardly reflexed, dise with a wide trausverse callosity, behind which a deep impression, posteriorly deeply punctured and trausversely rugose; elytra deeply punctured, sometimes entirely pale, but generally with the cuneus and the apex of the corium black or pitchy brown, membrane pale smoky; legs entirely pale, or with the posterior femora darker at the base.

L. $3 \mathrm{~mm}$.

Herne Bay, Chobham, Woking, Sonthrold; Bugbrooke, Northants, Murshall; Devon, I'aifitt; Corton, Herriugfleet. Suffolk, Butler; Deal, Billups; Knighton Heath, Dale.

T. minutus, Linn. (olscurus, D. S. S.; niger", Surnd. Syn. purs).-Smaller and wider than the preceding. Head transverse; pronotum distinctly wider in front than in majusculus, the sides being more ronnded and dilated anteriorly; the anterior transverse callosity is shorter, so that it does not approach so near the sides; in the of the lateral margins are less distinctly reflexed, especially posteriorly; in both sexes the anterior margin is distinctly more than half as long as the base, the basal portion of the pronotum is also less strongly rugose and punctured; elytra entirely pale as a rule, but sometimes with the cuneus darker; legs pale.

L. $2-2 \frac{1}{2} \mathrm{~mm}$.

Woking, Chobham; Reigate, Headley Lane, Oxshott, Billups; Stevenage, Butler; Norfolk, Edwards; probably common, but overlooked. 
BRACHYSTELES, Muls. \& Rey.

We possess only one out of the two European species of this genus. In my recent Catalogue I gave both, as from the literature that I was able to consult at the time I made out that the species which we have always known as Curdiastethus testaceus was the true testaceus of Mulsant, which Reuter now puts under Brachysteles as a synonym of rufescons, Costa. Since then, however, I have been able to consult Dr. Reuter's work on the Anthocoride (Act. Soc. Sc. Fenn. xiv. pp. 555 et seq.) and find that our species is the Cardiastethus fasciiventris, Garb. The two species are very closely allied in colour and size, but differ in the shape of the head.

Head short, transverse, about as long as the interval between the eyes, ocelli placed close to the inner margins of the eyes posteriorly, antennæ with the second joint siightly thickened at the apex, third and fourth subequal, clothed with long fine hairs; pronotum transverse, anterior margin two-thirds as long as the base, with scarcely any collar, sides rounded, base deeply sinuate; elytra short, margins rounded, widely reflexed at the base; legs rather short, simple; wing cell without a hook-like nerve.

B. parvicornis, Costa (pilicomis, D. \& S . ).-Short oval, dark brown, rather thickly clothed with pale hairs. Head and pronotum nearly black, rather shining, antenuæ pitchy-brown, clothed with long fine hairs, first and second joints rather thick, third and fourth subequal, thinner thau the second; pronotum with the sides produced and much rounded in front, base deeply sinuate, about once and a third as long as the anterior margin, dise punctured, with a deep transverse impression; scutellum black, punctured, with a deep central impression; elytra testaceous brown, clavus, cuneus, and apex of corium darker, membrane pale smoky.

L. $1 \frac{1}{2} \mathrm{~mm}$.

I'he short form and pilose surface will distingrish this 
little rarity from any of our other species. I took two off an elm hedge near Southwold in 1877, the only locality I know for it. Dr. Power has also captured it.

\section{CARDIASTETHUS, Fieb.}

Very like the preceding genus, but distinguished by the longer head, which is much louger than the width of the vertex between the eyes; tho pronotum in our British species is also much narrower in front.

C. fascii-ventris, Garb. (testacens, Perr., etc., nec Muls.).-Elongate oval, clear testaceous, clothed with very fine pale hairs, first joint of the antenna hardly reaching to the apex of the head; pronotum trapeziform, shining, anterior margin about half as long as the base, sides narrowly margined, nearly straight, base sinuate, dise with i shallow transverse impression, posteriorly finely wrinkled; scutellum shining, transversely impressed behind the middle; elytra finely punctured and pubescent, of rather a greyer tint than the head and pronotum, dull, membrane dark smoky; legs clear testaceous.

L. $2 \mathrm{~mm}$.

Rare. Horsell and Chobham, Surrey; Sheppey, Champion; Weymouth, Blateh.

XYLOCORIS, Dufs.

Flat, glabrous, elongate, parallel-sided. Head abont as long as wide across the eyes, eyes large, first joint of the antenne very short, not reaching to the apex of the head, third and fourth together much longer than tho second; pronotum trapeziform, without apical constriction, smooth and shining, with a scarcely perceptible transverse impression, sides slightly rounded, base sinuate; scutellum near]y Alat, slightly concave; clytra clongate, parallel-sided, membrane with four distinct nervures; legs short, femora slightly incrassated. 
There is only one species in the genus.

$\mathbf{X}$. ater, Duf.-Black, shining, glabrous, antenno with the second joint pale except at the apex; pronotum shaped as above, with a slightly impressed dorsal line; elytra sometimes more or less piceous, membrane white at the base ; tibia testaceous.

L. $2 \mathrm{~mm}$.

Under bark. Reigate, Chobham, Birmingham, Salford Priors, Blatch; Norfolk, Edwards; Sittingbourne, Caterham, Richmond, Champion.

\section{MICROPHYSINA.}

Second joint of antenno distinctly longer than the fourth, rostrum reaching beyond the anterior coxa joint of antennm not longer than the fourth, rostrum not reaching beyond the anterior coxæ. MYRMEDOBIA.

\section{MICROPHYSA, Westw.}

Males and females dissimilar, of with the olytra fully developed and shaped as in the Anthocorina, o with the elytra shortened or not fully developed, and the abdomen widely dilated and convex; face much produced in front, first joint of the antenum not reaching beyond the apex of the head, second joint longer than the fourth; ocelli large and well defined in tho $\delta$, less definite in the $q$; pronotum trapezoidal in the $\delta$, and in both sexes with a distinct apical ring not hidden at the sides by the anterior expansion of the lateral margin, dise with a deep transverse impression; scutellum in the of impressed posteriorly; elytra in the male fully developed; embolium well defined, in the $q$ abbreviated and in one piece; abdomen in the $?$ very wide and convex, partially or entirely exposed above; legs simple.

There are six Paloarctic species of this genus, of which two occur in this country. 
(2) 1. Head and thorax dull, male subelongate, female with the elytra covering half the abdomen thorax shining, male elongate,

(1) 2 . Head and thorax shining, male elongate,
female with the elytra not covering the abdomen at all .

M. pselaphiformis, Curt. $\delta$ brownish, head, pronotum, and scutellum nearly black, dull; basal joint of the antenne not quite reaching to the apex of the hear, third and fourth joints subequal, each about three-fourths as long as the second; pronotum much narrowed in front, sides nearly straight, not produced nor reflexed in front, so that the apical constriction is visible at the sides; base deeply sinuate, dise with a very deep transverse impression; elytra brown; embolium and cuneus reddish, the base of the latter paler; membrane pale smoky; legs pitchy brown.

o brown, finely pubescent, much shorter and wider than the $\delta^{3}$; head generully red at the base; pronotum short, transverse, subtrapezoidal, deeply impressed across the centre, and strougly raised in front; scutellum with au elevated ridge at the apex; elytra brown, much widened posteriorly, and subtruncate, leaving four abdominal segments exposed; abdomen much dilated posteriorly.

L. $\delta 2 \mathrm{~mm}$; 우 $1 \frac{1}{2} \mathrm{~mm}$.

On lichen-covered trees, under bark, etc., Coombe Wood, Woking, Bromley, Reigate, Tunbridge Wells.

M. elegantula, Baer-Much narrower and more delicate than the preceding. of elongate; head and pronotum slining, piceous, the former more or less reddish; antenna long, finely pilose; pronotum narrow, the sides sinuate, dise with a transverse impression, and a corresponding callosity in front of it, base widely sinuate; scutellum pitchy; elytra very long and parallel-sided, pale fawn-coloured brown, clavas, the base of the corium and embolium at the apex paler, cuneus red; membrane very large, wider than the elytra, very pale smoky brown; legs testaceous. 
q head and pronotum clear testaceous red, shining; antennæ dusky, second joint pale, except at the apex; pronotum very narrow, scarcely widened behind, transverse callosity very strongly marked; scutellum short, shining; elytra very narrow and short, testaceous, parallel-sided, truncate posteriorly, leaving the abdomen entirely exposed; this latter is round, very convex, shining and black; legs clear testacoous red.

L. ठ大 $2 \frac{1}{4} \mathrm{~mm}$. ; क $1 \frac{1}{2} \mathrm{~mm}$.

Not rare; on old lichen-covered trees, Reigate, Tunbridge Wells; Woking, Cholham, Ilfracombe.

\section{MYRMEDOBIA, Baer.}

$$
\text { (Pseudophleps, D. \&. S.) }
$$

Allied to the preceding in the dissimilarity of the sexes, but with the rostrum thicker and shorter, and the apical joint of the antennæ longer in proportion to the second; the head also in all our species, excopt inconspicua, is distinctly shorter and transverse. There are eight species recorded by Dr. Puton as Palaarctic, of which we have four.

(4) 1. Male, pronotum with a distinct apical collar, exposed at the sides; female eitler with the elytra covering the abdomen, or with the pronotam without transversa impression.

(3) 2. Larger, head, in the male, from the ocelli to the apex about equal to the interval between the eyes; temale, elytra covering the abdomen . . .

(2) 3. Smaller, head from the ocelli to the apex much longer than the interval between the eyes; female, elytra abbreviated

(1) 4. Male, collar of pronotum very narrow, the lateral margins bounding it at the sides, so that it is enclosed by the anterior angles; female, elytra abbreviated, pronotal transverse impression deep.

(6) 5. Male, anterior angles of pronotum dilated and reflexed; temale, lateral margins of pronotum reflexed . . . . .

(5) 6. Miale, anterior angles of pronotum not dilated; female, lateral margins of pronotum not reflexed

coleoptrata.

INCONSPICUA.

DISTINGUENDL. 
M. coleoptrata, liull. - o browuish black, hoad, proo notum, aud scutellum black. Head short, transverse; antenna with the fourth joint longer than the third, and subequal to the sccond; pronotum transperse, with the sides nearly straight, not dilated or produced in front, but gradually rounded to the anterior collar, which is complete, but short; surfaco transversely wrinkled; anterior callosity smooth, behind which is a transverse impression, base sinuate; elytra brownish, dull, clothed with very fine pale hairs; lateral margins rounded, reflexed; cuneus pitchy; membrane pale smoky; legs brown.

Fery short, oval, and convex, rather densely clothed with pale hairs. Head and pronotum more or less red, the latter short, without transverse impression, sides rounded in front, nearly straight behind; scutellum red; elytra convex, black, punctured, suture straight, like that of a beetle; abdomen entirely hidden by the elytra; legs testaceous.

L. $\delta 2 \mathrm{~mm}$. ; $q 1 \frac{1}{4} \mathrm{~mm}$.

Highgate IVood under dead leaves, Power; Spridlington, Lincolnshire, Wullaston; Barnet, Butler.

M. inconspicua, $D$. \& S.-Much smaller than the preceding, and easily distinguished in the $\sigma^{*}$ ser by its black colour, its proportionately thicker and louger antenna much longer head, longer more shining pronotum, which is scarcely wrinkled posteriorly, and has a much shallower transverse impression; the base also is less sinuate, so that the scutellum appears smaller; the elytra are glabrous, and not finely pilose ats in coleoptrata; legs black.

In the o the prowotum has no transverse impression, the head is reddish ait the base, and the abdomen is shining and glabrous, the elytra short, dull, only reaching on to the first segment of the abdomen; the entire insect, except the elytra, shining.

L. $\delta 11 \mathrm{~mm}$. ; q scarcely $1 \mathrm{~mm}$.

At the roots of grass on the sandhills, Southwold and Lowestoft; Weymouth, Blutch. 
M. tenella, Zelt.- $\delta$ like culeoptiata in genoral appearance, but at once distinguishable by the shape of the pronotum, which has its sides subparallel compared with those of coleoptrata, the lateral margins being dilated in front, and reflexed, the narrow apical collar lying between the produced dilated angles; the pronotum is shorter, and the transverse impression deeper.

o head more or less red; antennse with the first and second joints, except the apex of the latter, red, second joint nearly one-third shorter than the fourth; pronotum transverse, its sides nearly parallel, reflexed; dise with a transverse callosity in front of the middle with a doep channel behind it; elytra very short and rudimentary, only extending on to the first abdominal segment, truncate posteriorly; abdomen round, convex, slightly shining, punctured and clothed with pale hairs; legs testaceous.

L. ot $2 \mathrm{~mm}$. ; f $1 \frac{1}{2} \mathrm{~mm}$.

Woking, Southwold; Esher, Champion.

M. distinguenda, Reut.-Closely allied to the precoding, but the $\delta$ differing in having the anterior angles of the pronotum simple, not dilated as in tenella, and not constricted into a collar as in coleoptrata; the transverse discal impression also is much less marked than in tenella, and there is no impression at the base of the pronotum; scutellum and elytra more densely pilose than in tenella.

of very like tenella, but at once known by the longer antennæ, the second and fourth joints of which are subequal, the dull pronotum with simple unreflexed sides, and by the more closely punctured and more pilose abdomen.

L. $82 \mathrm{~mm}$. ; of $1 \frac{1}{2} \mathrm{~mm}$.

Busbridge, Surrey, on old lichen-covered larches, July, 1890 ; Esher, Champion.

\section{CAPSIDE.}

Of this very extensive family we have nearly sixty genera, and nearly 170 specios. There is probably no 
other family in which the generic characters are so indefinite, and this peculiarity makes it a most difficult one to work. Dr. Reuter, in his magnificent "Hemiptera Gymnocerata Europx," has divided the family into sixteen divisions, of which we have representatives in this conntry of ten. I have not been able to utilize these divisions, as they are not of equal value to those employed to divide the other families, being strictly equivalent to the subdivisions of the subfamilies. I have, however, as much as possible, kept to his arrangement, although the difficulty of making an analytical table has obliged me to depart from that arrangement in the table itself. I do not feel certain that Pithoms is naturally placed with the Continental genera Myrmecoris and Componoticleand dissociated from Alloduris, Etorhinus, etc, nor that Bryocoris and Monalucoris should be inserted between Leptopterna and Pantilius, but Dr. Renter's knowledge of the family is so exteusive that I do not feel justitied in proposing alteratious in the arrangement he has adopted.

The chief characteristics of the fumily are the following :Integument generally of a softer nature than in the other families, some of the species being extremcly soft and fragile; shape very variable, but usually of a more or less elongate oval, varying tu short oval. There are many species, however, which aro elongate and more or less parallel-sided, and many which are narrow in front and cousiderably dilated posteriorly; as a rule, the species are more or less convex. The head is generally smooth and declivous, but in some genera nearly horizontal or perpendicular; the eyes are generally placed near the pronotum, but in a few genera they are remote from it; the head is sometimes narrowed behind the eyes, and often has a carina dividing it from the nock; ocelli rarely distinguishable, antenuiferous tubercles very slight; antenna four-jointed, basal joint generally the thickest and the third and fourth generally the thinuest, althongh there are 
exceptions to the rule; rostrum four-jointed; pronotum variable in form, sometimes constricted in front into a narrow collar, sometimes with the frout margin callose, occasionally with the sides costate, base sinuate or rounded; scutellum exposed, sometimes spinose; elytra composed of corium, clavus, cuneus, and membrane, generally fully developed, but shortened and more or less rudimentary in some species, especially in the $f$. In some genern, Bryocoris, Allodapus, etc., the developed form of either sex is very scarce; the membraue has usually two basal cells, but occasionally only one, and no discal nervures except those enclosing the colls; wing cells with or without a hook-like nerve. The meso- and metasternum are divided by sutures into three parts, the sternum and a pleura on each side of it; the abdomen has two genital segments exposed, the apical one open above and holding the genital armature; in the of three genital segments appear, and a distinct ovipositor lies along the centre of the segments beneath; legs simple, coxæ very largely developed, especially the anterior pair, tibir often with a row of fine spines, tarsi three-jointed.

All the species occur in summer and early autumn, and subsist on the juices of leaves, etc.

(12) 1. Head channelled in the centre or transversely impressed on the verter; anterior margin of pronotum not callosely raised.

(1i) 2. First joint of the posterior tarsi much longer than the second.

(6) 3. Head channelled down the middle.

(5) 4. Base of pronotum truncate, covering the base of the punctured scutellum

(4) 5. Base of pronotum emarginate, not covering the base of the impunctate scutellum.

(3) 6. Head transversely impressed on the vertex.

(8) 7. Eyes not, or scarcely, projecting beyond the lateral margin of the pronotum

(7) 8. Eyes prominent, projecting considerahly beyond the lateral margins of

Miris.

Miggalocerea.

ACETROPIS. the pronotum. 
it Himiptera-IIteroptera.

(111) Elongate, depressed, glabrous above, or nearly so .

(ii) 11". Elongate, not depressed, clothed - with

2) 11. First and second joints of posterior

(1) 1: Head not chamnelled nor transversely

(68) 1:. Pronotum with the anterior margin raised and rounded; or constricted into a short collar-like neck; or much constricted in front and widened behind, with the sides sinuate and the posterior margin largely emarginate.

(17) 14. Pronotum with the lateral margins acute in front, anterior margin not callose.

(1i) 15. Eyes very prominent, species parallelsided, black and yellow, or red

(1i) 16. Eyes not very promineat, species oblong orate, ochreous with brown stripes vith

(11) 17. Pronotum with the lateral margins not acute in front, or with the anterior margin callose.

(4.) 18. Pronotum gradually raised and rounded from the narrow anterior collar to the base, its sides rounded or straight, rarely sinuate, base not largely emarginate.

(4) 19. Membrane with two cells.

31 20. Large or medium-sized species; neck more or less swollen, heal not divided from it even at the sides by a carina or raised line.

(2) 21. Rostrum produced beyond the posterior coxio.

(2.3) 22. Membrane marbled

Phytocoris.

(i) 23. Nembrane not marbled : Oxcognataus.

(2!) 24. Rostrum not produced beyond the posterior coxie.

24) 25. Species not deeply punctured nor mo gase.

(2i) 26. Second joint of antennæ not clavate. vate :

12.1 28. Species deeply pribctured or rugose.

(..i) 29. Surface glabrous, both sexes macropterous

(1) 30. Surface hairy, female generally brachy* pterous a small snecies; vertex

'Teratocoris.

LEPTOPTERYA.

I'ANILIIs.

Lopus.

Miruntts.

O.rognatius.

('Alud uris.

Rhopalotoyes.

Capsus.

Bumbates. 
of head completely or only in part (near each eye) divided from the neck by a transverse carina or rounded margin.

41) :2. Vertex carinated at least near the eyes.

(:i) :...3. Hemelytra and nervares of membrane scarlet - .

(i.i) 31. Hemelytra not scarlet.

:ivi) :i, Pronotam scarcely convex, transversely rugose, elytra glabrous. ."

iii) :ii. Pronotum convex, not transversely rugose, hemelytra more or less pubescent.

(4i) :7. Species not clothed with scattered, deciduous, golden pubescence.

,3:) is. Head very wide, rostrum reaching beyond the posterior coxa.

(is) 39. Head not very wide, rostrum reaching to about the posterior $\cos x$.

137) 40. Species clothed with deciduous golden.

(32) 11. Vertex not carinated, but with a rounded margin posteriorly, visible especially near the eyes, elytra glabrous.

(4ii) 12. Secoud joint of the antennw shorter than the third and fourth together.

(42) 43 . Second joint of the antenno longer than the third and fourth together.

(19) 11. Membrane with only one cell.

(1i) 15. Third and fourth joints of antemna subequal . . . .

(-1i) 40. Third joint distinctly longer than the fourth . . . .

14) 17. Pronotam constricted in front, raised and widened posteriorly, sides generally sinuate, base largely emarginate.

(4') 4: Basal joint of posterior tarsi nearly three times as long as the second?

(1i) 19. Basal joint of posterior tarsi not much longer than the second.

(iii) (it. Eres touching, or nearly touching, the anterior margin of the pronotum.

(iir) 51. Third and fourth joints of the antenna not, or scarcely, thinner than the apex of the second.

(53) 5\%. Antenna somewhat robust, bead with a slight vertical impression in the centre posteriorly :

Dichrooscytes.

Plesiocoris.

ZyGIMUS。

LYGUS.

Peciloscrtos.

LIOCORIS.

Camptobrochis.

BRYocoris.

Monalocoris.

Pituanus.

AlLOdarUs. 
(jii) 5. Head between the eyes flat, lower than the eyes an the eyes conver,

(i) $3 \mathrm{i}$. Head between the eyes convex, bigher than the eyes

(ii) it: 'Third and fourth joints of the antennx much thinner than the apex of the second.

(wiv) 5\%. Second joint of the antenne as long, or nearly as long, as the third and fourth together.

(iis) 58. Callosities of pronotum scarcely prominent, elytra in both sexes fully developel o pronotum very promi.

(is) 59. Callosities of pronotum very promi. nent, elytra in female generally not fully developecl

(ii) fil. Second joint of antenna much shorter than the third and fourth together.

(62) 6il. Faco nearly perpendicular, i.e nearly at right angles to the vertex, wing cells without a hook-like nerve

(61) fi- Face declivous, not nearly at right angles to the vertex, wing cells with a hook-like nerve

(iv) (i3. Eyes not nearly touching the anterior margin of the pronotum.

(fii) (it. Head constricted behind the eyes, eyes large.

(tivi) (in. Posterior femora grooved

Etorhines.

Campyloneura.

Crliocoris.

GLobiceps.

Mecoma AND

Cyrtorahines.

Byrsoptera.

(ii) (it. Posterior femora not grooved

(tif. it. Head not constricted behind the eyes, eyes small

(13) in. Pronotum with the anterior margin not raised and rounded, nor con. stricted into a short, collar-like neck, nor much constricted in front and widened behind in the same species where the sides are sinuate and the base widely emarginate.

(i) 69. Eyes not nearly touching the auterior margin of the pronotum . .

(f) Tu. Eyes quite or nearly touching the pronotum.

(7i) 71. Head posteriorly very thin and flat, covering the apex of the pronotum, posterior tibire somewhat flattened and curved not curved and fattened.

(i1) is. Posterior tibion not curved and fatten

(7) 7 . Wead posteriorly more or less covering the front of the pronotum.

(.) $\therefore$. Antenrae nearly twice as long as the body

Malacocoris.

Pilophords.

Systellonotus.

1)uxpers.

Macrolophes.

Haltios. 


\section{Capside.}

(ii) 7i. Antenna short, not so long as the bouly . . .

(7) 77 . Head not covering the pronotum in front.

(41) T. Species black, clothed with scattered golden or silvery deciduous scalelike pubescence.

(ni) 7:. Tibia with spine-like hairs .

(i:1) 4). 'Tibia without spine-like hairs

(F) Sl. Species not clothed with golden or silvery deciduous scale-like pubescence.

(hii) Si. Second joint of antenna much dilated and Hattened . . . .

(4-) s3. Second joint of antenna not dilated and thattened.

(4) St. Second joint of antenna very long, one lialf longer than the third and fourth together.

(si) s: Second joint of antennx not or scarcely longer than the third and fourth together.

(Mi) 86. Third and fourth joints of the rostrum together longer than the second, not incrassated

(\$6) 87. Third and fourth joints of the rostrum together not longer than the second, each slightly thickened towards their juneture.

(73) 88. Wing cell with is hook-like nerve (wanting in some specimens of Asciodema obsoletum).

(102) 8:!. Elytra opaque, dull, or at most only very slightly shiniug, never clothed with pale, deciduous, scale-like pubescence.

(91) :1. Tibia spotted with black

(INUTYLIS.

(90) 41. Tibia not spotted with black.

(93) J-3. Claws exceedingly short, strongly eurved, with an acute tooth at the base

(92) 4. Claws not very short, and not strongly curved, without an acute bisisl tooth.

(95) 41. Arolia longer than the claws

(94.) 4.5 . Arolia shorter than the claws.

(97) :4i. Rostrum very long, extending beyond the posterior $\cos \infty$.

(96) 47 . Rostrum not very long, not estending to the posterior coxæ.

(99) :15. Upper surface with fine, pale, regular puluecence, species subelongate

(98) 19. Upper surface clothed with brown or
Strongtzocoris.

Orthocepitalus.

HETEROCORDYLC9.

Heterotona.

\section{Isorops.}

Orthotyles.

JYI'SITYLITS.

Mfacrotylus.

Onychuments.

Ambeytrius.

Conosretuos. 
black hairs mised with paler, species sub-robust.

(101) 100. Antenno with the third and fourth joints very little thinuer than the second :

(100) 101. Antenure with the third and fourth joints much thinner than the second . in in

(89) 102. Ely tra shining, of ten clothed with pale

HOPLOMACHES。

Macrocoleus.

(104) 103. Second joint of the antenne shorter than the third . . Harrocera.

(103) 104. Secoud joint of the antenna longer than the third.

(108) 105. Tibire with pale spines.

(107) 100. Elongute, depressed, elytra parallelsided. .

(106) 107. Not elongate and depressed, elytra with siles ronnded

PIIYLUS,

(105) 108. Tibise vith black spines.

(112) 109. Elytra clothel with short, deciduous, scale-like pubescence.

(111) 110. Second joint of the antennw in both sexes incrassated.

Atractotomes.

(110) 11]. Second joint of the antenna not in-

(109) 112. Elytra clothed with fino regular hairs.

(114) 113. Femora entirely pale . . Ascioderia.

(173) 114. Femora more or less dark, or spotted with black or brown . . Plagiognathus.

\section{PITHANUS, Fieb.}

Subelongate, elytra rarely fully developed. Head transverse on the vertex; face nearly perpendicular; eyes large and prominent; antenno with the basal joint short and stout, the second and following much narrower; pronotum, in the developed form, widest behind, with the sides sinuate, in the undereloped form, widest in front, in both with a strongly developed lateral tubercle near the front margin, base sinuate; scutellum conver; elytra in the developed form with the cuneus very feebly indicated, as also are the basal cells of the rnembrane, in the undeveloped form the elytra are only about twice as long as the scutellum;

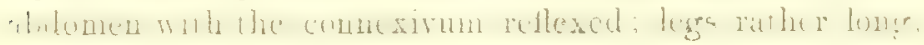


tibire not spined on their outer edge, posterior tarsi with the basal joint longer than the other two together.

There are only two recorded Palcarctic species of this genus, of which we have one in this country.

P. Mærkeli, II. S.-Black, nearly glabrous, oyes projecting for nearly their entire width beyond the sides of the pronotum, first joint of the antenna yellow except at the hase, second slightly curved, a little longer than the third, fourth about one-third the length of the third, vertex with an obscure pale diagonal line on each side between the eyes; pronotum constricted into a short neck in front, immediately behind which on each side is a strong lateral tubercle; in developed specimens the sides are thence sinuate and diverge posteriorly to the hind angles, in undeveloped specimens they are rounded, and converge to the angles; the base is largely sinuate in the developed form, and nearly truncate in the undeveloped; elytra black or brownish black, its lateral margins pale; membrane dusky; abdomen black; connexivum yellow; legs testaceous, slightly freckled with brown.

L. $4-5 \mathrm{~mm}$.

Common, and generally distributed, but not recorded from Ireland; taken by sweeping; developed form very rare.

\section{ACETROPIS, Fieb.}

Flat, subelongate in the male, elongate-oval in the + Head nearly horizontal, transversely impressed on the vertex, and also with a slight longitudinal impression; forehead produced over the facial lobes in a sharp point, first joint of the antenna about as long as the head, a good deal thicker than the following joints; eyes not quite touching the pronotum; pronotum trapezoidal, its sides reflexed and sharp; lateral margins of the elytra reflexed, and sharp; nerves of the corium very distinct and elevated; 
legs clothed with very fine short bristly hairs, tarsi with the first and third joints subequal in length.

The species of this genus, of which only one is at present recorded from Britain, closely resemble each other. The two ordinary European species, carinatus and Gimmerthulii, at first sight look almost identical, but in cariucutus the pale central line of the pronotum is strongly cariuiform, whereas in our species (Gimmerthatii) it is quite flat. It is not, I think, improbable that carinutus may yet be found with us.

A. Gimmerthalii, Flor (setienlosa, Ficb., D. S. S.).-Pale ochreous; head with a central dark stripe, darkest in the ơ; antenna with the first and second joints clothed with fine bristly hairs, basal joint thicker in the of than in the $\sigma^{*}$, second joint very long, third about as long as the first, fourth about two-thirds as long as the third; pronotum transverse, with a wide stripe down each side, and a narrow stripe on each side of the dorsal line, brown, sides widely reflexed, slightly sinuate; base shallowly punctured, nearly straight; scutellum with the basal angles and a line on each side of the centre, brown; elytra shallowly punctured, darker between the discal nerves of the corium, which are very prominent, sides subparallel in the $\delta$, more or less rounded in the $f$; membrane smoky; legs ochreous, clothed with very short fine bristly hairs on the tibia, tarsi black at the aper.

L. $6 \mathrm{~mm}$.

In dawp situations by sweeping. Rare; Wimbledon, Southrold, Woking; New Forest, Murshall; Birch Wood, Power; Fairlight, Collett; Deal, Kuighton Heath, Dale.

\section{MIRIS, $F a b$.}

Elongate or subelongate, depressed; eyes touching the pronotum, vertex with a longitudinal impression; antenna with the first joint robust, more or less hairy, about as long 
as or longer than the head; rostrum reaching to about the apex of the mesosternum; pronotum trapeziform, its lateral margins carinnted; base nearly straight, covering the base of the scutellum, which is punctured; elytra elongate, except in holsatus; legs elongato; posterior femora dentate in calcaratus, simple in the other species; tibix, especially the posterior pair, bent inwards near the base, except in holsatus. There are sir species recorded as European by Dr. Puton, of which we have three in this country; virens, Linn., I think, is likely to be found with us, but it might easily be mistaken for levigutus. It is, however, a stouter insect; the first joint of the antenne is shorter, scareely as long as the head, and the pronotum is wider.

(4) 1. Hind femora simple.

(3) 2. Insect elongate ovate, basal joint of antenna clothed with very short hairs . . . HoLsatus.

(2) 3. Insect elongate, basal joint of antenna densely clothed with long hairs. . . LEVIGATUS.

(1) 4. Hind femora toothed beneath . . Calcaratus.

M. holsatus, Fab.-Elongate ovate, ochreous or greenish, punctured; eyes rather large and prominent, vertical impression short; forehead margined with dark brown round each eye; basal joint of antennæ thick, rather longer than the head, clothed with short black hairs, second about as long as the third and fourth together; pronotum with all its margins nearly straight, rather wider at the base than long, dorsal line and sides pale, a line on each side within the pale margin darker; scutellum punctured, with a pale central carina, its basal angles black; elytra pale ochreous or greenish, with the clavus and corium inwardly brown; femora spotted with brown, tibix straight.

L. 5-6 mm.

Common and generally distributed in summer, taken by sweeping; some specimens hibernate, and occur in moss in winter.

M. lævigatus, Lim.-Elongate, punctured, groen, or 
ochreous, with darker lougitudinal lines; autenne and tarsi in green examples red. Head nearly as long as its width, impressed down the centre, basal joint of the antenure considerably longer than tho head, slightly curved, densely clothed with long hairs; pronotum about as long as its basal width, sides sinuate, with a dark line within the lateral margin, base nearly straight or slightly sinuate, dorsal line pale, raised and smooth; scutellum punctured, with a slightly raised central line; elytra either entirely green, or with the clavus more or less brown; or ochreaus, widely blackish grey inwardly; hind tibia considerably bent inwardly, the other tibire very slightly so.

L. $8 \mathrm{~mm}$.

Very common by sweeping grasses, etc. in summer, and generally distributed.

I. calcaratus, Fall.-Very like the precoding but rather wider, similar to it in colour, except that in the ochreous variety the elytra are pale throughout; antennæ rather shorter, the basal joint distinctly so, and the third and fourth together shorter than the second; pronotum shorter, wider in front; posterior femora beneath with a large curved tooth pointing outwards, followed by a shorter and straighter one between it and the apex, tibia curved as in lavigatus.

L. $7 \mathrm{~mm}$.

Very common by swoeping grasses, otc, and generally distributed.

\section{MEGALOCER王A, Fieb.}

A genus closely allied to Miris, from which it differs in the emarginate base of the pronotum, which exposes the base of the scutellum, and in the surface of the scutellum itself, which in this genus is smooth and impunctate, whereas in Miris it is strongly punctured. We find in Britain three of the four species recorded by Puton. 
(2) 1. Tibiro densely pilose, but without fine spines. ERRATICA.

(1) 2. Tibia not densely pilose but with very fine short spines.

(4) 3. Basal joint of the antennm nearly trice as long as the head. . . . . LONGICORNIs.

(3) 4. Busal joint of the intennim scarcely longer than the head.

RUFICORNIS.

M. erratica, Linn.-Pale green, with three stripes on the head and tro or four on the pronotum dark, or black, with the sides of the pronotum and elytra green or yellowish; in the latter variety the dorsal line of the pronotum and scutellum and the vertex of the head are generally pale also. Hyes rather prominent, first joint of the antenna about tivo-thirds as long as the head and pronotum, densely pubescent; pronotum indefinitely and feebly punctured, at the base broader than long, sides sinuate, base emarginate, disc with a raised central line; scutellum posteriorly with a raised central line, impunctate; elytra elongate, as long as the abdomen in the $\delta$, shorter in the $q$; posterior tibir slender and curved at the base in the $\delta$, thick and very slightly curved in the $q$, densely pubescent in both sexes, but especially so in the of.

L. 8-9 mm.

Common in grassy places, and generally distributed.

M. longicornis, Fall.-Pale green, pronotum with a brownish stripe on each side. Antennæ very long, basal joint nearly twice as long as the head, with only very short, semi-decumbent hairs, third joint longer than the second; pronotum with the sides slightly sinuate, disc feebly punctured; scutellum impunctate, with a pale raised dorsal line especially towards the apex; elytra as long as the abdomen in the $\delta$, sometimes shorter in the of; posterior tibia straight, bearing a fow fine, short spine-like hairs.

L. $9-10 \mathrm{~mm}$.

This very distinct species is local, but abundant where it occurs; Fairlight and Hastings; Deal, Dale; Taff's Well and Corvbridge, South Wales, Billups; Wymondley, Barnet, Hurst Green; on Brachypodium, Shalford, Boxbill and 
Mickleham, Butler; Pitlochry, Norman; Forres and Orkneys, Rruter; Rannoch, Murshall; St. Ives, J. E. Mrason.

II. ruficornis, Fall.-Dark or pale green, antenna and tarsi generally more or less red, basal joint of the antenne about as long as the head, third joint shorter than the second; pronotum with the sides sinuate, feebly punctured; scutellum with a slightly raised pale central line; elytra longer than the abdomen in the $\delta$, shorter in the of; legs slender, posterior tibire straight, with fine short spine-like hairs.

A form occurs on sandhills near the coast, which is larger and paler, with pale antennæ, but it is not considered by Dr. Reuter as more than a variety of this species; the third joint of the antennæ is shorter than in the typical form.

L. $6-8 \mathrm{~mm}$.

Common and generally distributed in similar situations to the other species of the genus.

\section{TERATOCORIS, Fieb.}

Rather similar to the two preceding genera in shape, but at once distinguishable by its transverse head, prominent rounder eyes, projecting considerably beyond the margins of the pronotum, and its transversely impressed vertex, and also by its dimorphic nature, both sexes occurring in the macropterous and brachypterous forms. We have three species in this country of the four recorded from Europe, all of which are more or less rare, and occur in marshy places by sweeping, especially near the sea.

(2) 1. Basal joint of the antenna red, smonth and nearly glabrous, its pubescence very fine and scarcely observable joint of the antennæ not red, with

(1) 2. Basal joint of the anten ANTENNATOS.

(4) 3. Basal joint of the antenma in the male shorter than the fourth, [ronotum and scutellum in that 


$$
\text { Capside. }
$$

sex liak with pale markings; female, hasal joint of the antenno once and a lalf as long as the head. . . . . . .

(3) 4. Basal joint of antennx, in the male, as long VIRIDIS as or longer than the fourth, pronotum and scutellum green with black markings; female, basal joint of the antennas once and twothirds is long as the head... SAunnersi.

T. antennatus, Boh. (dorsat is, D. \&; S.).-Pale green, glabrous, fadiug to ochreous after denth. Head transverse, deeply impressed on the vertex, black, or ouly with the centre black, eyes large and prominent, basal joint of the antenna red, often black at the extreme baso, more or less constricted near the apex, pilosity very fine and hardly noticeable, third joint about three-quarters as long as the secoud, first and fourth joints subequal; pronotum in the of black, with ouly the margins pale, or pale with black markings, in the o pale with the dorsal line black; in both sexes there is a deep transverse impression parallel to the anterior margin, sides sinuate, base emarginate; scutellnm black, varying to pale with a dark central line; elytra, rarely fully developed, varying from green with the suture only slightly fuscons, to brown with the lateral margins, widening at the base and apex, green or pale, membrane dark; legs ochreous, tibire and apex of the femora often red.

L. $\delta$ \% 4 , of $6 \mathrm{~mm}$.

Rare; Reigate; Wicken Fen; Shenpey, Champion; Ifunstanton, Weybourne and Rauworth, Edvourds; Lulworth, Dule; Camber, Butler; by sweeping in damp places, licuter says amongst Arundo Phrogmiter.

T. viridis, D. \& S.-Pale green, of with the head and pronotum black, the base of the former and the sides, base and two discal spots on tho latter pale, scutellum black; in the of only the dorsal line of the head bluck; antemne in both sexes green, basal joint distinctly hairy, not so long as in either of the other species, in the of about equal to the fourth in length, in tho o abont once and a latf as longe as the head ; third joint 
abont two-thinls as lomg as the sccond, fourth about threequarters as long as the thind; pronotum without the deep anterior transverse impression observable in antemutus, its sides and batse simuate; sentellum blqck in the of with the posterior angles pale, green in the $f$; elytra green: leges green.

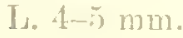

Rare, Ramnoch and Skye, Mursluell; Mumby Chapel,

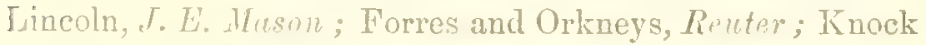
Barril, Perthshim, Tormun; Braemar to 1700 feet, F. P. White; Irelamt, Frulitay.

T. Saundersi, D. \& S.-Very like the preceding, but entirely green in both sexes, with the exception of a black lime which extends from the face to the base of the pronotum in the ${ }^{\pi}$ and in some specimens to the apex of the scutellum; in the of this line is sometimes indicated, but Jess strongly thau in the $\delta$; the antenna are longer than in virilis, and tho first joint is nearly twice as long as the head in the $\delta$, one and two-thirds as long in the of pronotum shaped as in virilis, lut if anything slightly longer; elytra rarely fully developed in the o; leg's green, hind femora and tarsi often reddish at the apex in the $\delta$.

[s. $5-6 \mathrm{~mm}$.

I) (xal, by sweeping rushes, etc, in a damp place near tho towir end of the sand-hills; Hunstanton, Weybourue and Ranworth, Brundall and Surlingham, Norfolk, Euwords; Morayshire, Forres, Aberdeen, lieuter.

\section{LEPTOPTERNA, Ficl.}

A very distinct geus, differing from the other genera with impressed vertices in the bright coloration and the hairiness of the surfuce. Il mal transverse, eyes large, prominent, not touching the pronotum, antenure robust, densely hairy, first joint as long as or longer than the head; pronotum trapezoidal, its sides simute and sharp, base

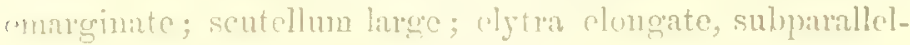




$$
\text { Copsida. }
$$

sided, fully developed in the of, rarely su in the of; legrs elongate, hairy. There are only three European species, of which wo have tro in Britain.

1. Colour black, brown anil redilish, tibia with

2. Colour black and yellow, tibia with long erect hairs

L. forrugata, Fall.-Head pronotum and scutellum black in the $\bar{\sigma}$, a line along the inner margin of each eye, produced to the base of the head, the lateral margins and central line of the pronotum whitish; of with the head pronotum and scutellum pale, two lines down the middle of the head, a spot on each side of the pronotam in front, and the sides and base of the scutellum more or less black; elytra in both sexes pinkish brown, the nerves red; legs ochreous, femora spotted with black. Antenno brown, black at the base in the $\delta$, finely hairy in the $\delta$, densely so in the 9 ; scutellum very large, in the developed forms as wide as the base of the pronotum; elytra longer than the abdomen in the $\delta$, about equalling it in the developed $o$, about trice and a half as long as the scutellum in the undeveloped i; legs very hairy, but the hairs only semierect, and shorter than in dolobrata.

L. $8-9 \mathrm{~mm}$.

Common by sweeping in dry grassy places, and generally distributed.

L. dolobrata, Lim.-Head black with five yellow spots in the $\delta$, or yellow with the dise black in the o, hairy, antenne hairy, black in the $\delta$, dusky brown in the + ; pronotum clothed with erect hairs, pale, with a black band down each side, leaving tho dorsal line and lateral margins pale, these latter sinuate, base nearly straight, rounded at the lateral angles; scutellum not so wide as the base of the pronotum, the posterior angles in the of, and these as well as the sides in the $\delta$, widely black; elytra yellowish in the $q$, ormane yellow in the $\delta$, clothed with 
erect hairs, inwmily dusky, the nerves yollow, membrane dusky, fully developed in the $\hat{o}$, in the + very short; elytra not so long as tho abdomen ( $I$ have never seen a macropterous f); legs clothed with erect dark hairs, femora with rows of black spots; abdomen with lougitudinal rows of spots.

L. $8-?$ m 1111 .

Very abuudiut, and generally distributed; occurs in dry norissy locilities.

\section{BRYOCORIS, Full.}

Dimorphous in both sexes, in the fully developed form with the lical trausverse viewed from above, eyes prominent, faco nearly vertical, antenua with the basal joint longer than the vertex, rostrum robust, reaching to about the middle of the unosusternum; prouotum very wide and outch raised behind, narrow and with a distinct collar in front, siles struight; elytra Hat, subparallel-sided, cuncus very limge, meubrane with only one basal cell; apical joint of the posterior tarsi, incrassated, arolia very long, divaricate. In the undeveloped form the pronotum is less widened behind, and the elytra are convex, without membrane. 'The tivo forms are so dissimilar' that I doubt it anyone would suspect their identity unless found wogether. There is only oue Huropean species.

B. pteridis, Fall.-Head and promotum pitchy brown, a line on each side of the former pale; head shiming. Antenna pale, tinely pubescent, apex of the second joint and the third and fourth, which are subequal in length, pitchy browu; pronotum junctured and transversely rugose, dull, base twice as wide as the auterior margin, sides struight; scutcllum pitchy brown, raised at the base; elytra pale ochreous, semi-transparent, shiming; clavus pitchy brown, corinm with a dark transverse band just athove the cunens; cuncus large, with its apical unargin 
brown, membrane hyaline clouded with brown; leggs very pale ochreous, finely pubescent.

Undeveloped form narrow, widened posteriorly, ochreous, head and sometimes the pronotum and scutellum darker; elytra punctured, convex, its sides rounded, membrane wanting.

L. $3 \frac{1}{2}-4 \mathrm{~mm}$. (developed), $2 \frac{1}{2}-3$ (undeveloped).

On l'teris and other fems. Dr. F. B. White finds it in Scotland "always on Athyrium filix femine and Lastreu dilcetatu."

\section{MONALOCORIS, Dahll).}

Not dimorphous, broadly ovate, shining, punctured, convex, face subvertical, rostrum reaching to the posterior coxæ; pronotum with a very narrowly raised anterior collar, sides very slightly rounded, base rounded; elytra short, their sides rounded and narromly reflexed, cuneus with its esternal margin rounded, constricted at its union with the corium, membrane with only one cell; apical joint of the tarsi slightly incrassated, arolia very long and divaricate. There is only one species of the genus.

M. filicis, Limn-Ochreous brown, shining, head, logs and the base of the antenna paler. Head shining, impunctate, eyes touching the pronotum and projecting beyond the sictes of its anterior margin, antenna with the basal joint slightly longer than the head, second about twice and a half as long as the first, dark at its apex, third and fourth dark, fourth about two-thirds as long as the third, vertex divided from the neck by a rounded ridge; pronotum strongly punctured, much raised posteriorly, with a transverse anterior impression on euch side, its anterior raised collar pale, sides nearly straighth, base rounded; elytra punctured, fincly pubescent, their margius pale, membrane smoky; legs very finely pubescent.

L. $2 \frac{1}{2}-3 \mathrm{~mm}$.

On ferns; gencrally distributed and common. 
PANTILIUS, Cur 。

A very distiuct genus, ensily known by its broad subparallel form, its deeply sulcate verter, the very long second joint of the antenuie and the very short thind and still shorter fourth, which is much thimner than the third; the pronotum is trapeziform, with a distinct anterior collar, the sides slightly reflexed and sharp, base slightly rounded; elytra with a narrowly reflexed uargin, somewhat prallel-sided, cuneus once and a half as long as wide; basal juint of the posterior tarsi short, about as long as the third. 'l'hure are two Ialwarctic species of this genus, of which we have only one.

P. tunicatus, Fah.-Somewhat flat, subparallel-sided, red, or green with a reddish tinge, freckled with small b]ack spots, bearing short black bristles. Head transverse, with the eyes large and prominent, vertex longitudinally impressed, antenne red or pale, with the basal joint longer than the heak, second three times as long as the first, slightly thickened and darkened at the apex, third abont c(puilling the first in length, much narrower than the second, formth about half the length and width of the third; projotum transverse, base about twice as long as the anterior maroin, sides slightly sinuate, sharp and narrowly reflexed, base rounded, slightly emarginate in the centre; elytra with the side margins uarrotvly pale, cuneus generally blood-red inwardly and at the apex, membrane dusliy, nervures blood red; legs red, or green tinged with red.

L. 8-10 mu.

On Hurel, Reignte, I3romley, Wimbledon; Alders, Esher, Snlisbury, Murshall; Devon, I'urfitt; "Common on Birch in antumn," Norfolk, Edwaids; ILazel, Well Vale, Lincolnshire, J. E. Mason; Glanvilles Wootton, Charmouth, Dale; Ireland, Hulliday; Husel, 'I'aff's Well, South Wales, and Micklelau, Billujs; Bickleigh, Plymuridge, Horrabridge, bivindl. 
IOPUS, Iruhn.

A genus of black or black-brown species, with red and yellow markings. Head viewed from above very transverse, with very prominent eyes, nearly their entire width projecting beyond the lateral margins of the pronotum, face subvertical, antennie with the basal joint hardly thicker than the secoud, rostrum reaching to ahout the posterior coxas; pronotum trapezoidal, with a distinct collar in front, sides sharp, base slightly rounded; scutellum convex; elytra nearly parallel-sided, longer than the abdomen in the 8 , generally shorter than it in the $q$; posterior tarsi with the basal joint not longer than the second, third joint the longest. We have three British species of the elevem recorded as Palwarctic.

(4) 1. Legs without pale rings.

(3) 2. Sides of the pronotum straight, its diso black . . . .

(2) 3. Siles of the pronotum sinuate, its dise with a central pale line ... Sulcatus.

(1) 4. Posterior femora and all the tibia with a pale ring . . . . flaromarginates.

L. gothicus, Lim. (var. superciliosus, D. \& S.).Black, clothed with erect black hairs, inuer orbits of the eyes pale, antenna black clothed with erect hairs, third and fourth joints subequal, basal joint about as loug as the anterior margin of the pronotum; pronotun with the anterior margin rather more than half as loug as the base, sides sharp, straight, more or less red, the red colour varying considerably in extent; scutellum black, red towards the apex; elytra coriaceous, punctured, lateral margius pale, cuneus orange red, with its inner apical margin black, membrane black; legs black, clothed with erect hairs, tibir somotimos piccous; beneath black, sides of the pronotum, a spot near each coxa, and a line on cach side of the abdomen, yellow.

Var. superciliosus, D. 5, S., differs in having the prunotun and cuneus cntircly blick. 
Reigate, Hastings, Woking; on Rubus idrenes, Norfolk, Tilucards; Mirch Woul, Mfrishall; Glanvilles Wootton, Boumemouth, Dale; Knowle, Camock Chase, Blatch; 'Taff's Well, South Wales, Billups; Coombe and New F'orest, Power.

L. sulcatus, Fieb.-Tike the preceding in style of coloration, but clothed with much shorter finer hairs; pronotum with its sides sinuate and yellow, and with at more or less wide yellow dorsal line down its centre, and with a deeper transverse impression than in yothicus; the scutellum has a central pale stripe and its apical portion is impressed at the base; elytra with a marcioal stripe, and the cuneus yellow except at the apex, membrane black, very much shorteved in all the females which I have seen; legs black, posterior femora in the of pale near the base, tiluie piceous in both sexes.

L. $6-7 \mathrm{~mm}$.

Hayling Island, cn flowers of Rulus, etc.; Devon, on Umbellifera, Parfitt; Harcham, Hants, H. Erancis; Ryde, Isle of Wight, Dale : Weston-super-Mare, Billupss; Slapton, on Sencio, Clenopudium and Anthyllis; Wembury, on Malva, Lignell.

L. Alavomarginatus, Don. (miles, D. \&. s.).-Easily known from either of the preceding by its browner colour, its very fine, pale, decumbent pubescence, which on the antenne and legs is ouly observable with a strong power; also by the long fourth joint of its antennx, which is much lovger than the third; the pronotum is much narrower in tront. its anterion margin not being lualf as long as the base, the anterior callosities are clearly defined and shining, and the dorsal line narrow and red, like the lateral margins; the elytra are very narrowly pale at the sides, the cuneus orange, with its innel apical margin brown; all the tibia and the posterior fomora have a pale ring.

1.. $7-7$. $\mathrm{mm}$.

Liare; ou Limuria ruigurix, Halfway Strect, Kent, Douglus 
and Scott; Colchester, Ilarwoorl; Fareham, Hants, carly July, H. Hrancis; Bolt Head, Devon, Polperro, IIurshall; Ireland, Haliday.

\section{MIRIDIUS, Fic .}

Elongate oval, face uearly horizontal, eyes touching the pronotum, viewed from above longer than wide, basal joint of the antennæe thick, long, slightly curved and pilose, once and a half as long as the head, rostrum very long, reaching to the middle of the abdomen; pronotum trapeziform, with a distinct anterior collar-like constriction, sides sharp, sinuate, base rounded, slightly sinuate in the centre; scutellum rather small; elytra long, their sides slightly roumded, cuneus long; legs elongate, tibir with fine spinelike hairs.

There is only one European species.

II. quadrivirgatus, Costa.-Pale ochreous, two longitudinal stripes ou the head, four on the pronotum, two on the scutellum, two on the clavus, and two or three on the corium and the cuneus inwardly, brownish red. Antenua fiuely pubescent, brown, basal joint with fine bristly hairs; pronotum at its base twice as wide as at the anterior margin, slightly raised posteriorly; scutellum convex, membrane smoky with a darker clond on each side, its nervures pale; legs ochreous, more or less freckled with brown.

L. 11-12 min.

Deal, Lowestoft, Ilastings; Hurst Green, Bexhill, Butler ; Bideford, I'aifitt; Isle of Wight, Cornworthy, Botus Fleming, Marshall; Beer Ferris, Bignell; Sheppey, Chanvion; Lulworth, Dale; Deal, and Barry Isle South Wales, billups.

\section{PHYTOCORIS, Fiall.}

A genus of elegantly shaped green, grey and brown species, mottled with darker colour and clothed with five soft pubescence, with very long anteuna, generally banded legrs, and mottled or irrorated membranes; cyes linge, pro- 
minent, round, face nearly vertical except in ulmi and vurifes, basal joint of the antennæe elongate, with a few bristly hairs on its inner margin, rostrum reaching beyond the base of the abdomen; pronotum trapezoidal, its anterior margin callosely raised; scutellum convex; elytra more or less elongate, parallel-sided or slightly rounded. Membrane irrorated with fine black spots, giving it a mottled appear ance; legs with the posterior femora elongate and slightly thickened, tibia elongate, with a row of fine laair-like bristles along their onter margin.

We have eight species in this comntry of the forty-one recorded by Puton as Palararctic; but the majority of these are meridional aud quito unlikely to occur with us.

(12) 1. Intermediate tibio with transverse bands.

(3) 2. Basal joint of the antenus with three

(2) 3. Basal joint of the antenna marbled with POPULI. black, but without black longitudinal lines.

(7) 4. Black bauts of the intermediate tibic narrower than the intervening white sluaces.

(6) 5. Sides of pronotum nearly always widely black, ely tra not very loug, clearly mottled with black excent in extreme varieties, posterior fewora normal very long and obscurely mottled, josterior femora very long and slemler...

(4) 7. Black bands of the intermediate tibia wider than the interrening white ones.

(9) 8. First joint of the antenua louger than the fourth of a

(8) 9. First joint of the antenna suberual to or shorter than the fourth.

(11) 10. First joint of the antenne nearly as long as the head aud pronotum together.

(10) 11. First joint of the antenna not nearly so long as the bead and pronotnm togetlier.

(1) 12. Intermediate tibia without transverse bauls.

(14) 13. Basal joint of antenna with long bristly hairs wot thickened.

TILI. I:

LONGIPEN N IS,

IIMIDIATUS.

REUTERI.

FINI.

(13) 11. Basal juint of antenm sliglitly thickenei, Tristles rery sliurt and fize . . TARITES. 
P. populi, Linn. (var. distinctus, D. \& S.).-Grey or ochreons, mottled with darker brown or black, sometimes (var. distinctus) with the elytra entirely black. Eyes very prominent, vertex in the male about as wide as each eye, in the of wider, basal joint of antennæ with three black longitudinal stripes, second joint about twice as long as the first, fourth slightly shorter than the third; pronotum with the sides slightly sinuate, more or less black posteriorly and at the sides, base slightly emarginate in the centre; scutellum with the sides and a central line, widening at the apex, pale; elytra usually more or less mottled with black, and clothed with fine silvery hairs intermixed with the darker ones, sometimes entirely black, with only a slight pale spot near the cuneus, membrane dark, marbled and irrorated with grey; femora marbled with black, tibia with black bands, those of the intermediate pair about as wide as the intervening white ones.

L. $6-7 \mathrm{~mm}$.

I cannot, after comparison of many specimens, distinguish var. distinctus except by colour, and I have intervening varieties which I am quite unable to refer to either with certainty.

On poplars; not very common, but generally distributed.

P. tiliæ, Fab. (var. marmoratus, D. S. S.).-Green or greenish yellow fading to yellowish after death, more or less spotted and marbled with black; basal joint of the antenux spotted with black, but without black longitudinal lines, slightly longer than the apical joint; pronotum almost always with a wide, well-defined, black band on each side, often continued along the base; scutellum and elytra marbled with black, varying much in the extent and arrangement of the marlings; membrane pale, irrorated with grey, giving it a marbled appearance ; femora marbled with black, tibire with black bauds, those on the intermediate pair very distinct and clearly narrower than the intervening white ones. 
L. (f) mm.

On limes and other trees, not rare and generally distributed.

P. longipennis, Flor. (dimidiatus, D. S. S. ner Fum.). -Longer, narrower, paler and more obseure in its mottling than any of our other species of this genus. Head ochreous, eyes very large and transverse in the $\delta$, each being much wider than the vertex between them; in the o the eyes are not transverse and are slightly narrower than the vertex; antenno very long;, longer than the entire iusect, first joint as long as the head and pronotum together; pronotum greyish ochreons, with darker markings; scutellum with a pale central line; elytra very long, parallel. sided, greyish ochreous, obscurely mottled with darker colour, membrane irrorated and marbled with grey; legs with the femora very long and sleuder, marbled, intermediate tibia with very distinct black bands, much narrower than the interveuing white ones.

L. 7-7룔 $\mathrm{mm}$.

Reigate, Hastings, Wimblerton on Hawel; Blackheath, Donglus and Scolt; Norfolk, Edwurds; Corton near Lowestoft, Butler; on Hrizel, Bath, Bluthwayt; St. Ires, Well Vale and Muckton, Lincolushire, J. E. Mason; Bewdley, Matlock, Blutch; Edinburgh, Forres, Perth, lienter; Caterham, Clattenden, Chumpion; Oxshott, Billips:; Ireland, Hafiday; Eastham Wood near Liverpool, J. W.Ellis.

P. Reuteri, Sound. (crussipe's, D. S. s. net Flor.).Smallor, shorter and darker than the preceding; bassil joint of the antenua shorter than the head and pronotum, second about once and a quarter as long as the third, first and fourth joints subequal; pronotum with the sides and base, and sometimes the dorsal line towards the base, darker; seutellum with a pale line at the apex, sometimes almost entirely pale; elytra hrown, marbled with lighter colunr, or sometimes almost entirely dark, cuncus dark, curium with the usual pale patch just ubove it; legs with 
the femora marbled, tibiro banded, intermediate pair with the dark bands wider than the pale ones.

L. $6 \mathrm{~mm}$.

On fruit trees, etc.

Reigate, Wimbledon, Chobham; Norfolk, Edwards; orke, Lincolnshire, J. E. Ifason; London District, MTickleham, Champion; Cardiff, Billups; Dartford Brent, Douglas and. Scott.

P. dimidiatus, Klm. (dubius, D. \&. S.; populi pars, S'aund. S'ynops.).-Very like some varieties of populi, but distinguishable by the absence of the lougitudinal black lines on the basal joint of the antenna; closely allied also to lienteri, but rather more slender, more mottled, less brown in colour, and with the third joint of the antenna proportionately shorter and the first joint longer, being distinctly longer than the fourth; from pini the long basal joint, which is as long as the pronotum and head to the brow of the forehead, distinguishes it at once; from longipennis its shorter antenne and legs, and more robust form, will separate it.

L. $7 \mathrm{~mm}$.

Reigate, Bromley, on oaks; Norfolk, Ellwarls; Furres, Edinburgh, lieuter.

P. pini, Kbm.-Shorter and stouter than any of the preceding, ochreous brown, mottled with darker brown. Antenne with the basal joint hardly longer than the pronotum, and subequal to or shorter than the apical joint; pronotum wider in front than in most of the species, its sides straight; mottling of the elytra very obscure; femora mottled, tibia with obscure bands, the dark bands of the intermediate pair much wider than the pale ones.

I. $6 \mathrm{~mm}$.

On fir trees, Pitlochry, Nurmin; Perth, Dunkeld, Forres, Braemar, Di. B3. IThite.

P. ulmi, Linn. (divergens, D. S. S.).-Reddish brown, elytra mottled with patches of white pubescence; vertex in 
the of slightly willer than each eye, in the o abont twice as wide as each, basal joint of the antenue slender, pale, mottled with brown, about as loug as the pronotum and the lead to tho front of the eyes, with long fine bristles, especially on the inner side, second joint a little more than twice as long as the first, fourth slightly shorter than the first; pronotum narrow in front, sides sinuate with a for bristly hairs near the anterior margin; scutellum rather shining, pale rerldish ochreous; elytra nearly unicolorous except for the pubescent mottling, elongate, parallel-sided in the, shorter with the sides rounded in, their lateral margins towards the apex and the apical half of the cuneus blood-red; nembrane marbled with grey; femora marbled with brown, tibio pale except at the baso.

L. $\left(0_{0,3}-7 \mathrm{~mm}\right.$.

Common on elms, and generally distributed.

P. varipes, Boh. (ulmi, D. \& S. nec Limn.).-Can only be confounded with the preceding, which it superficially resembles, especially in colour. The thicker basal joint of the antenne, with scarcely observable bristles, the pale central line of the lead, the three short pale lines on the anterior part of the pronotum, the wider vertex, the pale central lime of the scutellum, the unmottled elytra with darker longitudinal stripes, and the entirely red cumous will, however, distinguish it easily.

L. $6-6 \frac{1}{2} \mathrm{~mm}$.

Common and generally distributed, occurs on various plints.

CALOCORIS, Fieh.

(Derocoris, D. \&. T.)

An extensive geuts, very variable in the form and colour of its species, some being highly coloured, others of a dull greyish green or brown. Head not divided from tho neck by a ridge or rounded olevation, rostrum not reacling beyond the posterior coxa, antenne variable; promotum 


$$
\text { Capside. }
$$

with a narrow raised collar; scutellum convex; elytra parallel-sided or with the sides slightly rounded; $\delta$ and $q$ generally very similar; tibia with a row of fine spine-like hairs, although very sliort in some species; basal joint of the posterior tarsi slightly longer than the second. We have twelve species of the sixty-seven recorded by Puton, i.e. including Pycnopterna and Megaculum, which he gives as distinct genera.

(22) 1. Antennx inserted near the apex of the eyes.

(19) 2. Rostrum reaching beyond the intermediate coxa.

14) 3. Species not green.

(13) 4. Species not brick red.

(i) 5. Apical joint of antennx much shorter

(5) 6. Apical joint of antenna longer than

(8) 7. Corium entirely dark, unicolorous - EULvoßaculatus.

(7) 8. Corium not entirely dark.

(1.2) 9 . Scutellum pale, or with pale markings.

(11) 10. Elytra black with yellow markings - SExGUTTATUS.

(10) 11. Elytra greenish with red stripes - Roseoraculatus.

(9) 12. Scutellum entirely dark . . . SETICORNIS.

(4) 13. Species brick red . . . . TICINENSIS.

(3) 14. Species green.

(16) 15. Third and fourth joints of the antenna as thick as the second .

(15) 16. Third and fourth joints of the antenna thinner than the second.

(18) 17. Larger, apical joint of the antenno longer than the third . . . ALPESTRIs.

(17) 18. Smaller, apical joint of the antenno shorter than the third . - BIPUxctatus.

(2) 19. Rostrum not reaching beyond the intermediate coxa. (Subg. Pyenopterna.)

(21) 20. Basal joint of antenna longer than the head : .

(20) 21. Basal joint of antenna shorter than the

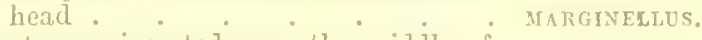

(1) 22. Antennæ inserted near the middile of the eyes. (Subg. Megacelum.) . INFuses.

C. striatellus, $L^{\top} a b$. (var. fomicatus, D. \&. S.).-Pale yellow, shining, a ceutral stripe on the head, the antennas towards the aper, four spots on the dise of the pronotum, 
and the base except in the middle, black; scutellum black at the extreme base; elytra with the -nerves margined with brown on each side, its sutures and margins also dark, cuneus black at the apex. Antenne with the basal joint not incrassated, third and fourth together about equalling the second; pronotum with a very uarrow callose collar, base rounded laterally; elytra very finely pubescent; legs orange, femora with a paler band in the centre, posterior pair slightly incrassated, apex of the tibie and of the tarsi darker.

In var, formicatus, D. S. S., the colour is of a redder hut, and the black markings loss distinct; those of the elytra nearly absent.

L. $8 \mathrm{~mm}$.

Common and generally distributed on oaks.

C. fulvomaculatus, De G.-Darker clive brown $\delta$, paler $f$, sparingly clothed with fine shining golden pubescence, cuneus outwardly pale ochreous, with a reddish tint in the + ; apex of the second joint of tho antenne, the centre of the head, and two spots on the pronotum, black; these latter are hardly observahle in the $\delta$. Basal joint of the antenna incrassuted, about as long as the head, third and fourth narrower than the second, subequal, and together longer than that joint; collar of the pronotum only slightly raised, sides sinuate; elytra parallel-sided in the $\sigma$, widened behind the midale in the of ; membrane dark with a lighter spot near the apex of the cuneus; femori mottled with durker brown, posterior pair incrassated, tibia ochreous, with short black spines.

L. $7 \mathrm{~mm}$.

On Blwck Cumunt bushes, Darenth, Douglas whal Seroft; Leatherhead, Billupss; Rergate, Barnstaple on Tmbelliferip; Glanvilles Wootton and Portand, Lule; On ILach, Bath, Bluthount; New Horest, Dorohouter, and Knowle, Blatele; Ash, Exeter, P'writt; on Wmbetlifere, Cornworthy and l3otus Eleming, Muskull: Guestling and Instings, Collett; 
Wymondley, Herts, Butler; co. Antrim, Rev. W. F. Johnson; Caterham, Champion; Bickleigh Vale and Horrabridge, Devou, Bignell; Birch, July, Strathglass, F. B. White.

C. sexguttatus, Fab.-Black, shining, collar of pronotum, the margin on each side towards the base, a wide dorsal line, the apical half of the scutellum, the apex of the clavus, and the lateral margin of the elytra, the colour of which spreads on the basal half, very pale yellow, cuneus orange, its apex black, leg's with the tibire pale. Basal joint of antenna slender, not thicker than the second, third and fourth thinner, together longer than the second; pronotum very nariow in front, its sides sinuate; elytra punctured, nearly parallel-sided, membrane black, with a liyaline spot below the apex of the cuneus; femora brownish black, posterior pair slender.

\section{L. $7 \mathrm{~mm}$.}

By sweeping, abundant in some places, Ilfracombe; "common" near Barlaston, Staffordshire, J. W. Ellis; Glanvilles Wootton, Dale; Headley Lane, Canterbury, York, Llantrissant, Billups ; Norfolk, Edwards; Redhill, Surrey, J. Limnell; Repton, Fowler; Ambleside, Butler; Cornworthy, Colvend, Kirkeudorightsbire, F. B. White; Kidderminster, Groby, Leicester, Marshall; Pitlochry, Forres, Norman; Caterham, Champion; Bickleigh Vale, Shaughbridge, Horrabridge, Devon, Bignell; Lucan, co. Dublin, J.M. Browne; Wymondley, Herts, Butler.

C. roseomaculatus, De G. (ferryatus, D. \& S. S.Greenish-ochreous, clothed with short, black hairs, head and pronotum more or less tinged with red or brown, the head black in the of except at the sides, scutellum with a central black line, elytra, clavus, except at the apex and along the central nerve, and the corium posteriorly between the nerves, red or brownish, membrane dusky, nervares pale. Basal joint of the antenuæ slightly incrassated, third and fourth distinctly slenderer than the second; pronotum. 
with a uarrow callose collar, sides straight, base slightly rounded, surface punctured; elytra considerably narrowed posteriorly; posterior femora incrassated, sometimes freckled with brown.

L. $8 \mathrm{~mm}$.

Common, by sweeping in dry places, and generally distributed.

C. seticornis, Fab.-Dark brown, clothed with fine pale golden pubescence, second and third joints of the antenne and sometimes the collar, dorsal line and extreme base of the pronotum pale ochreous, base of the corium outrardly also pale, cuneus blood-red, its apex black, membrane dark brown, tibia and the apices of the femora ochreons, beneath with a spot near each coxa pale. Basal joint of antenure slender, hardly thicker than the second, which is only slightly thicker than the third and fourth; pronotum obsoletely punctured, its sides nearly straight; elytrasubparallel-sided, finely punctured; femora hardly incrassated.

L. $8-8 \frac{1}{2} \mathrm{~mm}$.

I have one variety in which the corium is nearly entirely ochreous.

Rare. Thornes Bay, Luccombe, Isle of Wight, Power; Freshwater, Isle of Wight, $F$. S. Saunders; Chattenden, Chumpion; Filey Yorks, Charmouth Dorset, Fowler.

C. ticinensis, $M F^{2} y$-Pale brick red, clothed with fine pale pubescence, rurely with a greenish tinge in places, sometimes with two black spots on the pronotum, and occasionally with the inner apical angle of the corium dark. Head shining, antenne with the third and fourth joints lardly thinner than the second, first joint slightly thickened; pronotum with a very narrow callose collar, punctured, slightly shining, anterior callosities welldefined, sides nearly straight; elytra dull, with the lateral margins slightly rounded; femora slightly darkened, tibia pale ochreous with black bristles along their 
outer margin, abdonen beneath sometimes black in the centre.

L. $7 \mathrm{~mm}$.

Rare; in marshy places, Gomshall, Chobham; Norfolk, Edwards; Wicken Fen, Blatch; Leigh Woods, Clifton, Reed; Knighton Heath, Dale; Chilworth, Surrey, Butler.

C. alpestris, Mey.-One of our largest species, entirely green, clothed with fine brownish black hairs, eyes not touching the pronotum, first joint of the antennæ slender, but slightly thicker than the second, which again is thicker than the third and fourth, fourth a trille longer than the third; third and fourth together subequal to the first and second; pronotum narrow in front, sides nearly straight, anterior callosities well marked; scutellum very convex; elytra very long and parallel-sided in the male, their sides slightly curved in the $q$, cuneus long, membrane slightly smoky; posterior femora slender.

L. $10-10 \frac{1}{2} \mathrm{~mm}$.

Rare. Burton-on-Trent, Brown; Forres, Norman; Gibside, Bold.

C. chenopodii, Fall.-Greyish green, clothed with pale hairs, the extreme lateral margin of the elytra and the corium in the centre often dark, differs from either of the preceding in the thicker antenna, the third and fourth joints of which are as thick as the second, the fourth scarcely half as long as the third; pronotum very narrow in front and wide behind, especially in the $\delta$, often with two black spots on the disc posteriorly, surface transversely wrinkled; scutellum generally with two dark discal lines; elytra parallel-sided in the $\delta$, the sides slightly rounded in the + ; cuneus paler than the corium, membrane slightly dusky, nervures darker; femora freckled with brown, posterior pair slender, tibir with bristly hairs and small black spots.

L. $81-9 \mathrm{~mm}$. 
On Chenopudium, Ononis, etc., common and generally distributed, but not recorded from Ireland or Scotland.

C. bipunctatus, Fab.-Green, clothed with rather thick black hairs, pronotum generally with two small black spots on the disc, elytra in the $\delta$ sometimes more or less reddish brown between the nerves, membrane dusky, nervures pale, femora more or less freckled with brown. Basal joint of the anrenure scarcely thickened, third and fourth slenderer than the second, together about equalling it in length; pronotum shining, much raised posteriorly, with a narrow raised collar, sides nearly straight, surface slightly wrinkled transversely; elytra with the sides slightly rounded; posterior femora slightly incrassated.

L. $7 \mathrm{~mm}$.

Abundant everywhere on various plants in the summer.

\section{(Søвa. MEGACELUM, Fieb.)}

C. infusus, II. Schf.-Shining, glabrous, orange yellow. Head longitudinally impressed on the vertex, first joint of the antenux scarcely thickened, the rest subequal in width, fourth slightly longer than the first, third slightly shorter than the secoud; pronotum with a narrowly-raised collar, sides nearly straight, base sometimes with a wide black band; scutellum varying from orange yellow to entirely black; elytra subparallel-sided, in somo specimens unspotted, in others with a spot above the cuneus, or with a wide black band across the apex of the corium; membrane dark; legs in dark examples orange red, tibire darker; abdomen varying from yellow to nearly black.

L. $8 \mathrm{~mm}$.

On oaks.

Reigate, Charlwood, Gomshall, Wandsworth, Bromley; Lewisham, Douglas and Scott; Lee, Oxshott, Chobham, Loughton, Billups; Knighton Heath, Dale; Ashtead, 
Champion; Norfolk, Elwards; Devon, Parfitt; Wymondley, Herts, Barnet, Hastings, Butler.

\section{(Suba. PYCNOPTERNA, Fieb.)}

C. striatus, Linn.-Subelongate, head and pronotum black, a line near each eye, and a spot in the centre of the pronotum, sometimes extended into a transverse band, yellow; first joint of the antennx slenter, black or red, second black, twice and a half as long as the first; third black, yellow at the base; fourth black, four-fifths as long as the third; eyes not touching the pronotum; pronotum elongate, with rather a long, very slightly raised collar, sides sinuate, margins of the anterior acetabula raised so as to be visible from above as prominences on each side of the pronotum in front; scutellum black, sometimes yellow at the sides; elytra brownish, its nerves only, in dark examples, and the interstices more or less, in pale ones, pale orange yellow, cuneus bright orange, sometimes clouded with brown, membrane brown, nerves orange; legs orange red, femora towards the apex brown; tibial spines extremely short.

L. $10 \mathrm{~mm}$.

Darenth Wood, Tunbridge Wells, Douglas and Scott; Bewdley, Dean Forest, Blatch; Alders, Dunsford, Devon, Parfitt; Great Wood, Keswick, Marshall; Guestling, Collett; Abbotswood, Butler; Pitlochry, Forres, Norman; Rannoch, F. B. White; Aviemore and New Forest, Champion; Headley Lane and Llantrissant, Billups; Glanvilles Wootton, Portland, Dale; Bickleigh Vale, Horrabridge, Cann Wood, Devon, Bignell; Ireland, Hatiday.

C. marginellus, Fab.-Black with yellow markings. Head with a pale streak near each eyo, antennæ with the basal joint short, but not much thicker than the second, second nearly four times as long as the first; pronotum with the sides sinuate, collar and three lines or longitudinal basal 
spots yellow, base rounded; scutellum and elytra black; clavus and corium outwardly, and sometimes two pale lines on the dise of the latter, yellow; cuneus yellow or orauge; membrane black; legs pitchy brown, femora slender, tibie rather paler, spines very short; beneath with a yellow spot near the coxæ, and a pale band on each side of the abdomen.

L. $8 \mathrm{~mm}$.

Apparently very rare, I know of ouly one recorded locality for it. "Charing, Kent, rare," Rev. T. A. Marshall. I have an old specimen without locality from Harding's Collection, and Douglas and Scott record two specimens, also without localities.

\section{ONCOGNATHUS, Fieb.}

Closely allied to Calocoris, but distinguished by its longer rostrum, which reaches to the centre of the abdomen, and by the longer basal joint of the posterior tarsi, which is twice as long as the second. There is ouly one recorded species.

O. binotatus, $F^{\top} u b$. 0 ochreous yellow, o pale greenish; both sexes with black markings, the black more exteusive in the of than in the $q$. Head shining, a spot on each side of the vertex, and the central lobe of the face black; antenna dusky, basal joint about as long as the head, third and fourth together about equal to the second; pronotum trapezoidal, punctured, shining, a broad black band down each side in the $\sigma^{*}$, a spot on each side in the $q$ black; scutellum pale, its basal angles black; elytra finely puboscent, punctured, in the of with the clavus, except at the apex, and the corium inwardly, black, in the o varying from a coloration somewhat like that of the $\delta$, though paler, to entirely pale green; membrane dark fuscous, nervures pale; legs dusky, greenish ochreous.

L. 6-7 mm.

Common by sweeping by road-sides, etc., nnd generally distribnted. 


$$
\text { Cupsidte. }
$$

\section{DICHROOSCYTUS, Wieb.}

Subelongate, elytra parallel-sided, vertex of the head carinated posteriorly on each side near the eye; eyes prominent, rostrum reaching to about the third abdominal segment, antennæe slender, first joint about as long as the vertex between the eyes, second thicker in the male than in the of ; pronotun transverse, with a narrow raised collar; tibix with very fine spines, posterior femora slightly incrassated, apical joint of the tarsi very long, almost equalling the first and second together. We have only one British species, three being recorded from Europe.

D. rufipennis, Fall.-Shining, green, pubescence very sparse; elytra blood-red, with the margins narrowly green; antenna with the second joint as long as the third and fourth together; pronotum with the sides slightly rounded, base nearly straight; scutellum convex, sometimes with an orange tinge; elytra parallel-sided, membrane slightly smoky, nervures red; legs green.

L. $6 \mathrm{~mm}$.

On Conifers, Reigate, Chobham, Bromley; Norfolk, Edwards; Well Park, Lincolnshire, J. L. Mason; Nunton near Salisbury, Marshall; Braemar at 1200 feet, $F$. B. White; Pitlochry, Forres, Norman; Scarborough, Laneson; Bournemouth, Knighton Heath, Dale.

\section{PLESIOCORIS, Ficb.}

Elongate oval, elytra subparallel-sided in the ${ }^{\circ}$, sides rounded in the $q$, vertex of the head carinated posteriorly ; rostrum reaching to the intermediate coxa; antenna rather robust, first joint rather longer than the vertex between the eyes, third and fourth together about equal in length to the second; pronotum transverse, trapeziform, transversely wrinkled, with a narrow raised collar and two strongly marked callosities behind it. 
P. rugicollis, Full-Bright green; head, pronotum in front, sides of elytra and legs yellow. Antenna with the third and fourth joints and the extreme apex of the second, black; fourth joint about two-thirds as long as the third; pronotum only slightly raised posteriorly, strongly rugose transversely, sides straight; scutellum slightly convex towards the apex, raised down the midlle; elytra indefinitely punctured, membrane nearly hyaline, nervures green; tarsi black at the apex or entirely so, sometimes also the apex of the tibix of the same colour.

L. $6 \mathrm{~mm}$.

On willows and sallows, local; Woking, Denl; Saltcoats, Douglas : Walkham Valley, Devon, Bignell; Wells, Lincolnshire, J. E. Mason; Wallasey Sandhills, J. W. Ellis; Aviemore, Champion; Pitlochry, Norman; Forraby and Crosby, $F$. Archer.

LYGUS, Hahn。

$$
\text { (Urthops, Fieb.) }
$$

This rather extensive genus cousists of a number of species of very similar general facies, the most aberrant of our species being $L_{\text {. }}$ pabulinus, belonging to a little section of three species, of which it is our only representative; these differ from the others by the incomplete carina at the back of the head, which is only visible near each eye; the old subgeus orthops is only distinguishable by the shorter antenum.

Oval or elongate oval. Head with the face subvertical, vertex cariuated entirely or in part; rostrum reaching to about the third pair of coxa; pronotum convex, with a narrowly raised collar, base much raised; elytra with the sides more or less rounded; tibiæ with fine, sometimes black spines, secoud joint of tarsi slightly longer than the first.

(10) 1. Green, autennæe very long and sleuder, lege green. 


$$
\text { Capsida. }
$$

(3) 2. Vertex carinated only near the eyes, spines of the tibias very tine, hardly noticeable distinct.

(2) 3. Vertex carinated throughout, tibialspines PABULINLS.

(i) 4. Tibial spines strong and black, not rising from black spots.

(ii) 5. Cuneus entirely green

(1) - Tibial spines fine, brown, rising from black spots.

(9) 8. Clavus more or less brown . . .

(3) Clavus entirely green not very long and slender, or with the legs orange red.

(24) 11. Membrane not irrorated.

(ini) 1\%. Species not orange red.

(1.1) 13. Femora orange red, cuneus entirely green . . . . . livatus.

(13) 11. Femora not orange red, or with cuneus red at the apex

(1ii) $1 \therefore$. Species large, rolusust, $5-6 \frac{1}{2} \mathrm{~mm}$.

(15) 1ri. Species small, $3 \frac{1}{2}-4 \frac{1}{2} \mathrm{~mm}$.

(16) 17. Elytra with a wide semicircular dark band posteriorly.

(17) 1s. Elytra without a semicular dark band.

(2i) 1:. Second joint of antenna more than twice

(19) 20. Second joint of antennm not quite twice

(2.:) 21. Pronotum longer, its sides in front gradu. ally converging to the anterior collar.

(21) 2.. Pronotum shorter, its sides in front rounded, suddeuly converging to the anterior collar

(12) 23. Species orange red .

(11) 24. Membrane irrorated with grey dots

SPIYUL.E.

VIRIDIS.

C.NTAMINATUS.

PRATENSIS.

VISCICOLA.

CERVINUS.

KALMII.

PASTINACR. RUBRICATUS. ATUMARIUS.

L. pabulinus, Linn.-Green, elongate oval, slightly shining, punctured, clothed with pale hairs; antennæ with the apex of the second joint and the third and fourth joints black, basal joint about as long as the head, third joint about three-quarters as long as the second, fourth about three-quarters as long as the third; pronotum with a narrow raised collar, sides nearly straight, base rounded, anterior callositios strougly developed; scutellum transversely rugose; elytra elongate, their sides 
slightly curved, membrane with a longitudinal cioud below the apes of the cells; femora elongate, tibix with very fine, scarcely noticeablo bristles.

L. $6 \mathrm{~mm}$.

Common and generally distributed on nettles and othor plants; generally fades to yellowish brown after death.

L. contaminatus, Fall. (sulcifivins, D. \&. S.).-Green, clothed with pale hairs, eyes very prominent, vertex between the eyes in the of much narrower than each eye, in the $q$ about as wide as the eye; antennse with the apex of the second joint and the third and fourth brown, third and fourth together subequal to the second; pronotum very convex and much raised posteriorly, punctured, transversely wrinkled, sides and base rounded; scutellum transversely wrinkled; elytra fuely and closely punctured; corium with a more or less extonsive dark transverse spot above the inner angle of the cuneus, membrane dusky, with a darker spot near the apex of each cell, another near the apex of the cuneus, and sometimes one on the apical margin; tibia with short brown spines rising from black spots.

L. $6 \frac{1}{2}-7 \mathrm{~mm}$.

On birch-trees, Woking, Reigate; Barnet, Sevenoaks, Ewhurst, Butler; Weybridge, Phillups; Darenth, Dartford, Shirley, Mickleham, Douglus and Scutt; Norfolk, Edwards; Knowle, Berdley, Blatch; St. Ives, Cornwall, Mason; Forres, Norman; Armagh, Johnson.

L. viridis, Fall. (contaminatus, D. \& s.).-Extremely like the preceding, but distinguishable at ouce by its smaller eyes and wider vertex; in the of the vertex between the eyes is about as wide as each eye, in the o much wider; the clavus also is brown, or partly brown, instead of wholly green as in contuminatus, and the spot at the apox of the corium is generally larger.

L. $6 \frac{1}{2}-7 \mathrm{~mm}$.

Iustiugs; Croydun, Shirley, Darenth, Micklelam, Lsher, 
Douglus and Scott; Barnet oulis, Ewhurst, Butler; Norfulk, Elwarls; Trench Woods, Dorchester, Blatch; Forres, Nornan; Plymbridge, Devon, Bignell.

L. limbatus, Full.-Allied to the prececling, but shorter, paler and of a yellower colour, with the black markings more pronounced, recognizable by the orange-red femoru. In some varieties the scutellum and the base of the pronotum are nearly black, the clavus brown, and the apical spot of the corium very large and black. In some continental specimens the base of the pronotum is widely black, as well as the whole of the clavus. There are generally two darker red rings at the apex of the posterior femora; tibia pale, with black bristles rising from black spots.

L. $5 \mathrm{~mm}$.

I know of only one locality for this pretty species, Wimbledon Common, where a few specimens were taken by my nephew and myself in August, 1880, off Salix.

L. lucorum, Mey. (var, nigro-nnsutus, Rout. nec Stal.). - Short oval, very convex, green, clothed with pale hairs, shining, punctured, vertes between the eyes about as wide as the eye itself, central lobe of the face sometimes black; pronotum much raised posteriorly and very conves, deeply and largely punctured, base rounded; scutellum transversely rugose; elytra very finely and closely punctured, its sides rounded, corium above the inner angle of the cuneus sometimes with a dark spot, cuneus entirely green, membrane dusky, with darker spots; tibia with black spines, not rising from black spots, femora rarely ringed.

L. $5-5 \frac{1}{2} \mathrm{~mm}$.

On Spircea and other plants; not rare. Hastings, Reigite, Southwold; Norfolk, Edwards; Bexhill, Barnet, Shalford, Butler; Barnstaple, Marshall; Bickleigh, Horrabridge, Devon, Bignell ; Tatf's Well, South Wales, Billups; Achilty and Colvend, F. B. White. Var. nigro-nasutus has occurred at Corton, near Lowestoft, Butler.

L. Spinolx, Mey.-Very like lucorum, but rather. 
larger aud paler in colour and with the extreme apex of the central lobe of the face and of the cuneus black, membrane paler; posterior femora with two narrow brown rings at the apex, tibia with black spines not rising from black spots.

On Syircea, etc., Woking, Bromley, Reigate, Choblam; Headley Lane, Billups; Hastings, Lewes, Sevenoaks, Barnet, Wymondley, Shalford, Fritton and Corton, Suffolk, Butler; Norfolk, Edwards; on Myrica, Strathglass, F. B. White; Tilgate, Caterham, Eshor, Champion.

L. pratensis, Fub. (var. campestris, Fub.).-A most variable species, usually testaceous, more or less marked with darker colour; some specimens, howover, are black, others almost entirely pale green, others again reddish brown, with darker markings. It varies also much in puncturation and brilliancy of surface. The characters by which it may be known from its congeners are, the comparatively short antenne compared with any of the preceding species, which do not reach beyond the apex of the clavus; its much larger size compared with any of the species of the Orthops group; tho very fine short spines of the tibire, and the two dark rings at the apex of the posterior femori.

L. 5-6 $\mathrm{sm}$.

The race or variety pratensis has the elytra much more sparsely punctured and the punctures larger, and is generally a more convex and more brightly coloured insect; campestris has the elytra very closely punctured, and is generally dull brown or greenish. Both forms are common and generally distributed.

L. viscicola, Put.-Short oval, greenish jellow, generally the base of the pronotum, the scutellum chiefly, the base of the elytra and a broad semicircular baud at the apex often uniting with it at the sides, red-brown, thus leaving a small discal patch or band, common to both elytra, in the midnle; cuneus pale, its inner margin and apex bloodrod; femora red, with two darker apical rings. Autenna 
with the third and fourth joints together considerably shorter than the second; pronotum strougly punctured; scutellum wrinkled transversely, sides and apex more or less pale; elytra finely and closely punctured, clothed with pale hairs; membrane dusky, the cells, except at the apex, a spot below the apex of the cuneus, and a transverse central band, clear; tibir with very fine bristles; abdomen green.

L. $4 \mathrm{~mm}$.

Taken in some numbers by Dr. Chapman off mistletoe near Hereford, also by Mr. Edwards at East Carlton, near Norwich, by Mr. Dale in Dorsetshire, and by Mr. Bignell at Walkham Valley, Devonshire.

L. pastinacæ, Full.-Short oval, shining, green, more or less marked with brown or black, vertex between the eyes, in both seres, nearly twice the width of the eye, face often with a dark centre, third and fourth joints of the antenne black, together equalling the second, second black or black only at the apex; pronotum strongly punctured, sides rouided in front, suddenly converging to the anterior collar, disc and hind angles sometimes brown, entire base occasionally black; scutellum entirely green or with a small basal black triangle; elytra distinctly and rather largely punctured, clavus, and often an apical band on the corium, brown, or sometimes black, cuneus green, its apex rarely brown or black, membrane scarcely dusky; abdomen green, more or less spotted with black; legs green, in some very dark varieties the posterior femora have two dark rings.

L. $3 \frac{1}{2}-4 \mathrm{~mm}$.

On Pastinaca sativa, and probably other umbelliferm; abundant in many places, and generally distributed.

L. Kalmii, Linn.-Like some dark varieties of the proceling, but with the ground colour testaceous, not green, rather more elongate in shape, the pronotum longer, its sides gradually converging to the anterior collar, elytra more closely punctured, and the posterior femora with $t$ wo a pical 
dark rings. Antenne black; head with the centre black ; pronotum black with only the dorsal line pale, or pale with only the callosities and hind angles blick; scutellum dark or pale; elytra varying from entirely pale with the apex of the cuneus only red, to pale, with the clavus, a broad apical band on the corium, and the apex of the cuneus, widely black; membrane dusky; legs testaceous, two rings on the posterior femora, the inner one widest, and one on each of the others dark brown; tibia with fine spines.

L. $4-\frac{1}{2} \mathrm{~mm}$.

Common on Uimbelliferx and generally distributed.

L. cervinus, $H$. Schf. - Somerv hat like the preceding, but duller and more closely punctured, and with the markings paler; brownish testaceous, vertes betwoen the eyes very marrow in the o, not nearly so wide as either eye; antenni with the third and fourth joints black, extrome base of the third pale, together considernbly shorter than the second, the apex of which is black; pronotum deeply punctured, hind angles, and sometimes a line along the base brown; scutellum often with two wide central stripes; elytra very finely and closely punctured, generally with a more or less distinct, wide, apical band on the corium, cuueus with the apex brown or red; legs pale, posterior femora with two narrow subapical brown rings, spines of the tibia exceedingly short.

L. $4 \mathrm{~mm}$.

On limes, ash, etc.; generally distributed.

I. rubricatus, Fall. - Subelongate, entirely pale orangored, clothed with very fine pale hairs. Antennzo long aud thin, reaching almost to the cuneus, third and fourth joints dusky, together as long as the second; pronotum deeply punctured, elytra rather closely so, their sides subparallel or slightly rounded, membrane with a cloud within the apex of the cells, and another below the cells; tiviro prie, with fine spines.

L. $5 \mathrm{~mm}$. 


$$
\text { Capsida. }
$$

On Conife's; not rare. Reigate, Southwold, Woking, Bromley; II urst Green, Barnet, Shalford, Butler; Littlehampton, Chobham, Mickleham, Darenth, Champion; Glanvilles Wootton, Dale; Llaudaff, South Wales, Billups ; Ireland, Ilalidıy; Nunton, Leicester, Murshall; Norfolk, Edwards.

L. atomarius, Mey.-Elongate oval, strongly punctured, somewhat dull, testaceous with a reddish tinge, clothed with a fine pale pubescence, sometimes more or less irrorated with black, or with a dark stripe on each elvtron, membrane dark, scutellum often with a dark central line. Head black in the centre in the $\sigma^{\pi}$, vertex between the eyes about as wide as each eye, in the of nearly once and a half as wide with only a central spot; pronotum short, convex, very strongly and closely punctured; elytra very closely but not so strongly punctured as the pronotum; membrane irrorated with darker spots; all the femora with two subapical rings, tibio with strong black spines.

L. 4-5 mm.

Hitherto only recorded from Stratton Strawless, near Norwich, off silver firs, by $\mathbf{M r}$. Edwards.

\section{ZYGIMUS, Fieb. (Hadrodema, Fieb.)}

This genus, of which we have only one species in Britain of the three recorded by Puton as Palæarctic, appears to differ from Lygus only by the very wide head and more prominent eyes, and by the slightly longer rostrum. Our species is of a testaceous or testaceous-brown colour, very deeply punctured, and occurs on Conife's.

Z. pinastri, Fall-CShort oval, shining, testaceous, more or less tinged with brown in the $\delta$. Head smooth and very shining, hardly punctured, vertex very wide, eyes 
large and projecting considerably beyond the lateral margins of the pronotum; basal joint of antenna short, second longer than the third and fourth together, these latter subequal; rostrum thick, reaching to beyoud the posterior coxa, central lobe of the face black; pronotum very largely and deeply punctured, darker in frout, especially in the $\delta$, base rounded; scutellum largely punctured; elytra more finely punctured than tho pronotum, sides subparallel in the $\sigma$, slightly rounded in the $q$, apex of the cuneus darker in the $\delta$; membrane dusky; logs with the femora spotted at the apex, the spots of'ten connected so as to form two apical rings, spines of the tibis very short and inconspicuous.

L. $4 \frac{1}{2} \mathrm{~mm}$.

Confers; Weybridge, Chobham, Woking, Bromley; Hurst Green, Buxhill, Barnet, Ewhurst, Shalford, Mickloham, Lowestoft, Corton, Fritton, Somerleyton, Butler; Norfolk, Edwards; Morayshire, Norman; Oxshott, Plumstead, St. Fagan's, South Wales, Billups; Gianvilles Wootton, Dale; Esher, Champion.

\section{PCECILOSCYTUS, Fieb.}

(Systratiotus, D. \&. S. Charagochilus, Fieb.)

May bo known from all the other genera in which the pronotal collar is raised and callose by its vestiture of scalelike, deciduous, golden pubescence; the rostrum is short, only reaching to the intermediate coxe, and the posterior femora are incrassated.

We have three British species of the ten recorded by Puton in his Catalogue.

(4) 1. Elytra not black and yellow.

(3) 2. Femora pale at the apex and ringed . Grumentali.

(2) 3. Femora entirely black . . . . NIGRITUS.

(1) 4. Elytra black and yellow. . . . UNIFASCIATOS.

P. Gyllenhalii, Full.-Brown-black, clothed with small irregular patches of golden squamose pubescence, very cou- 
vex, short oval, eyes large, antennx testaceous, dusky towards the apex; pronotum short, very much raised and very convex posteriorly, deeply punctured, base rounded, its estreme margin marrowly pale; scutellum convex, transversely rugose; elytra punctured, in fresh examples closely irrorated with small patches of silvery-gold pubescence, cuneus red-brown, paler at the base and apex, deflected, together with the entire apical margin of the corium, almost at right angles to the rest of the elytra; membrane dark brown, nervures pale. Mr. Douglas (Ent. Mo. Mrg. xvii. 164) records a $o^{\pi}$ in which the entire ely tra are horizontal, and the membrane enlarged both in length and breadth ; femora brown, pale at the apex, the pale colour traversed by a brown ring; tibire ochreous, sometimes brown at the base; orifice of the odoriferous sac large, surrounded by a wide, foliaceous pale margin.

L. $31 \mathrm{rm}$.

On Urtica and Galium; generally common.

P. nigritus, Fall.-Black, slightly convex, clothed with golden deciduons pubescence. Antenna rarely with the centres of the second and third joints paler, third and fourth joints together longer than the second; pronotnm rugosely punctured, considerably raised posteriorly, but much less so than in Gyllenhalii; scutellum transversely rugose and punctured; elytra closely punctured, apex of the corium just above the cuneus and the cuners itself pale ochreous, the latter with a black spot just above the apex; membrane brown, cells and their nervures yellow, with a brown central patch; femora black, tibia black, or pale with the base, apex, and a ring above the middle, black, tarsi black, sometimes pale at the base; beneath black, orifice of the odoriferous sac small, transverse, with a pale foliaceous margin posteriorly.

L. $4 \frac{1}{2}-5 \mathrm{~mm}$.

On Galium, Stachys sylvatica, etc. Local, but apparently not rare where it occurs. Mickleham, on Stachys, 
Douglas and Scolt; Deal, Billuns; Bickleigh, Devon, Bignell; Caterham, Champion; Dover, C.G. Hall; Stevenage, Wymondley, Shalford, Butler.

P. unifasciatus, Fub.-Oblong oval, black, clothed with golden deciduous pubescence; antenua, at least at the base, a spot near each eye, the extreme base of the pronotum, the aper of the scutellum, the base of the corium its inner and outer margins and its apical margin above the cuneus, yellow; cuneus blood-red, black externally, and zellow at the base and apex; membrane dusky, nervures pale; legs pale ochreons, femora red or brown except towards the base, extreme apex of tibire and tarsi black. Vertex between the eyes in the of narrower than each eye, in the of considerably broader; pronotum shallowly and rugosely punctured; elytra more finely so, its sides subparallel in the of, rounded in the of beneath with the margins of the acetabula and the sides of the pronotum yellow; orifice of the odoriferous sne small and elougate; abdomen sometimes with yellow spots.

L. 6-6? $\mathrm{mm}$.

Not uncommou on Galium, and generally distributed.

\section{CAMPTOBROCHIS, Fieb.}

We have only one representative of this little genus of the five recorded in Puton's Catalogue. It may be recognized easily from its allies by its shining, glabrous surface, which is very strougly punctured, and by the ecarinate vertex of the head, as well as by the very short third and fourth joints of the antenwa, these together are much shorter than the second, which in the $\sigma^{*}$ is much thicker than in the + ; tibis withont spines.

C. lutescens, Schill. (punctutus, D.s. S.).-Subconvex, oval, testaceous, shining, glabrous, very strongly punctured, pronotum entirely, or only its callosities, scutellum sometimes except at the apex, the corium more or less, 
a band across the cuneus near its apex, one or two bands on the posterior femora, and two narrow bands on all the tibia, brown; the darker varieties are generally males. Head short, transverse, antenna with the apex of the second, third, and fourth joints brown, third and fourth subequal, and about as long as the first; pronotum very clearly and remotely punctured, sides nearly straight, baso rounded; scutellum impunctate, very shining; elytra punctured, more largely and deeply so on the clavus, its sides slightly rounded, membrane slightly smoky, nervures dark; tibir not spinose, beneath dark brown; orifice of odoriferous sac large, and surrounded by pale foliaceous plates much as in Perciloscytus Gyllenhalii.

L. $4 \mathrm{~mm}$.

By sweeping and beating Limes and other trees and plants; Douglas and Scott record it from I'teris; I have beaten it from MLaples; Reuter mentions it as occurring on Tanacetum and Achillea; Reigate, Woking, Chobham, Bromley; Linzes, Norfolk, Edwards: Hale Lind, Epping Forest, Butler; Nunton and Surbiton, Larshall; very common on Limes, Bath, Blathwayt; London district, Champion; Barry Island and 'Taff's Well, South Wales; Byfleet, Billups.

\section{LIOCORIS, Fieb.}

Oval, convex, glabrous, finely and remotely punctured; antenne longer than the body, head ecarinate on the vertex, rostrum reaching to about the posterior coxæ; pronotum very convex, anterior margin callosely raised; scutellum flat, sides of elytra rounded; tibie with black spines, second tarsal joint longer than the first. There is only one European species.

L. tripustulatus, $F a b$.-Head shining, impunctate, brown or entirely pale, antennie testaceous, second joint more or less black at the base and apex, third and fourth 
together longer than the second; pronotum convex, trapeziform, shining, largely and remotely punctured, black, with the dorsal line, widening in fromt, palo yellow, varying to entirely testaceous with the hind angles black; scutellum yellow, its base sometimes with a black spot; elytra finely punctured, black, with the extreme base, a central lateral band and a band across the cuneus pale yellow, varying to ochreous, with an apical band across the corium and the apex of the cuneus brown, membrane dusky with two clear palo spots in a transverse line ; femora pale, with two dark subapical rings; tibio with the base, apex and a narrow ring below the base, brown or black; beneath black or pale, orifice of sac much as in Camptobrochis.

L. $5 \mathrm{~mm}$.

Very common, and generally distributed; occurs on nettles.

\section{CAPSUS, Fab.}

A genus of well-marked, mostly highly coloured species. Head without any carima or rounded margin posteriorly, eyes very prominent, their entire width projecting beyond the lateral margin of the pronotum, antenne with the second joint finely pilose, more or less thickened at the apex, especially in the $q$, third and fourth joints much thinner than the second, and together much shorter than it; pronotum very narrow in front and wide behind, anterior collar very thin and raised; elytra and pronotum very strougly punctured; posterior femora slender, spines of the tibia very short, hardly noticeable; orifice of sac large, with foliaceous plates.

We have two British species of the eleven recorded as Palæarctic by Puton.

C. laniarius, Lim.-Rather short oval, shining, glab. rous, very strongly and rugosely punctured, ot and $q$ similar in outline. Head and pronotum black, varying to ferruginous yellow; antenna black, or with the centro 
of the second joint paler, second joint in the of gradually thickened from the base to the apex, in the o rather suddenly incrassated apically, clothed in both sexes with fine hairs; pronotum with the anterior margin about a quarter as long as the base, sides nearly straight, base rounded; scutellum black or yellow; elytra widest behind the middle, side margins much reflexed in front, entirely black with only the base of the cuneus bright red, and the base of the corium dull red, varying to entirely ferruginous yellow, with the apex of the cuneus only black; membrane blackish, with a clear spot below the apex of the cuneus; femora black at the base, pale at the apex, tibir pale, often clouded with brown towards the base; beneath dark, sometimes more or less yellowish.

L. $7 \mathrm{~mm}$.

All my dark examples are males. Common by sweeping nettles, etc., and generally distributed.

C. scutellaris, Fab.-Deep black, shining, strongly punctured; a line across the back of the head, and sometimes the scutellum, blood-red; male much longer, narrower, and more parallel-sided than the $q$; the second joint of the antennæ slightly thicker, but in neither sex so much thickened at the apex as in laniarius; pronotum more closely punctured than in the preceding; scutellum quite smooth, shining and impunctate; elytra closely punctured, mombrane dusky, unspotted.

L. of $8 \mathrm{~mm}$. o $6-7 \mathrm{~mm}$.

Rare. I have taken both varieties on heather at Chobham. Oxshott, Billups; Knighton Heath and Walmer, Dale; Hildolveston, Norfolk, Power; Dartford Heath, Douglas and Scatt; Reigate.

\section{RHOPALOTOMUS, Fieb.}

A well-marked genus, easily known from the others of this group by the strongly clavate second joint of the 
antenu: punctured, finely pubescent elytra; the pronotal collar is very short, and only slightly raised, and the anterior margin nearly half as wide as the base; the sides are nearly stmight and the base slightly rounded; legs with the posterior femora somewliat incrassated, tibio spinose, first and second joints of tarsi subequal. There are four Palcarctic species, of which we have only one.

R. ater, Lim.-Entirely black, or with the head, pronotum and legs red; second joint of nutenne very narrow at the base, strongly clavate at the apex, fourth longer than the third, third pale at the base, third and fourth together about equalling the second; pronotum very strongly punctured, anterior callosities smooth and shining; scutellum transversely wrinkled; elytra very finely and closely punctured, clothed with fine grey hairs, sides slightly rounded in the of, considerably so in the $q$, membrane dark; femora in the red-legged rarieties with one or two apical rugrs, sometimes dark at the base, tibia black or red with the apex dark, tarsi, apical joint black; beneath black.

L. $6 \mathrm{~mm}$.

Common by swecping, and generally distributed.

\section{BOTEYNOTUS, Fieb.}

Male subelongate, parallel-sided macropterous; female short oval, generally brachypterous; surface very rugosely punctured and pilose. Head with the eyes not touching the pronotum, antenna with the third and fourth joints together longer than the second, second very pilose in the $\delta$; pronotum with a raised collar, sides straight, base rounded; elytra, in the developed of with the cuneus and membrane much deflected, in the $\delta$ nearly horizontal; posterior femora slender, tibire not spinose. 


\section{Capsida.}

There is only one European species.

B. pilosus, Boh. (Minki, Fieh., D. \& S.).-Pitchy black or brown, legs in the of paler, of with the head and legs red. Head smooth, shining, vertex very wide, and eyes small and prominent, basal joint of the antennæx in the o, and sometimes the second, except at its apex, red; pronotum very rugose and hairy; scutellum deeply impressed at the base, the sides and apex raised; elytra rugosely punctured and hairy, its side margins reflexed, membrane dusky; in the brachypterous form the elytra are about twice as long as the scutellum; legs pale brownish red in the $\delta$, shining and red in the $q$; in the developed of before me the tibire are distinctly longer than in the undeveloped one; tarsi black.

L. $\delta 6 \mathrm{~mm}$. ; dev. $q 5 \mathrm{~mm}$, undev. $q 4 \mathrm{~mm}$.

Very rare. On the hills between Loch Long and Loch Lomond, four specimens, Sharp; Cuckmere District, Hastings, developed + , Collett; in a sandpit, Guestling, near Hastings, two undeveloped specimens, liev. $L$. N. Bloomfield; Booton Common, Norfolk, by sweeping, Edwards; Reuter has taken it off Spmuce Fir in Finlund, in August.

\section{PILOPHORUS, Hahn。}

\section{(Camaronotus, D. S. S.)}

This very distinct genus might be known from any other of our British genera by the brown colour and transverse silvery bands of its elytra; but besides theso characters the flattened head posteriorly, which overlaps the front margin of the pronotum, the prominent eyes which project for nearly their entire width beyond the sides of the pronotum, and the slightly curved and flattened posterior tibioo distinguish it at once from its allies. We have three closely allied British species of the seven recorded as Ialæarctic. 
(2) 1. Corium with its entire aprical width shining . . . . CINNAMORTERTS.

(1) 2. Corium shining only outside the median

(1) 3. Silvery band at the apex of the clavus nearer the base of the elytra than that of the corium.

(3) 4. Silvery harks of the clavus anu corium in one line . . . . . . PERPLexts.

P. cinnamopterus, $\pi l m$ - - Head brown, first joint of tho antenur and the second at the base, paler brown, apex of the second black, third at the base, and the fourth, except at the extreme apex, pale whitish; pronotum black, trapeziform, conver, sides straight; scutellum black, with a bright silvery line across its apex; elytra widest behind the middle, dull cinnamon brown, a short narrow band in front, arrested at the claval suture, and a complete band continued across the clavus, posteriorly, of bright silvery pubescence; elytra behind the second silvery line darker and shining; cuneus and membrane much deflected, tho latter obscure brownish grey; legs cinnamon brown; beneath with a band of silvery pubescence on the meso- and metasternum, and one on the abdomen towards the base.

L. $5 \mathrm{~mm}$.

On firs, rare. Norfolk, J. Elwards ; Plumstead, Douglas and Scott; Shiere, Dr. Capron; Weybridge and 'Taff's Well, Sonth Wales, Billups.

P. clavatus, Lim.-Like the preceding in form and style of coloration, but longer, and narrower, the pronotum especially being longer in proportion to its width, with the sides slightly sinuate; the entire surface of the insect also is more pubescent, being clothed with fine scattered golden pubescence, and the general colour of a darker, less cinnamon-coloured brown; the head and pronotum have a bronay tint, scutellum with a less distinct silvery band at the apex, posterior silvery baud of the corium not meeting that of the clavus, but placed distinctly below it, inner half of the corium at the apex dull, legs darker than in cinnumopterus, and the posterior tibia narrower. 
L. $5-5 \frac{1}{4} \mathrm{~mm}$.

On sallows; Woking; Norfolk, Edwards; Barnet, Shalford, Butler; Oxshott, Billups; Lee, Douglas and Scott; Tilgate, Champion.

P. perplexus, D. \& S.-Easily sepcrated from clavatus by the continuous band across the apex of the clavus and corium, otherwise exceedingly like it ; it is, however, rather smaller, and less pubescent, destitute of the fine golden hairs of clavatus, the colour rather brighter, the head and pronotum scarcely bronzy, and the second joint of the antennæ slightly less clavate; it is also more variable in colour.

L. $4 \frac{1}{2}-5 \mathrm{~mm}$.

On various trees, Chobham, Bromley; Lewisham; Deal, C. G. Hall; ; often in company with ants.

SYSTELLONOTUS, Fie\}.

o elongate, macropterous, $q$ brachypterous with the abdomen nearly round, twice as wide as the head; very much like an ant in shape. Head larger, and more globose in the $q$ than in the $\delta$, eyes not touching the pronotum in either sex, antennæ of nearly equal thickness throughout, rostrum reaching to the posterior coxæ, basal joint very thick; pronotum trapeziform in the $\delta$, more or less campanulate in the \&; elytra with shining white markings, very short in the $f$, not reaching to the dilatation of the abdomen; legs slender.

We have only one species, often found in company with ants, which the of very closely resembles in general form. There are six Palæearctic species.

S. triguttatus, Linn.-Chocolate brown, elytra paler. Head and pronotum shining, clothed with erect hairs, third joint of the antennæe almost as long as the second, fourth shorter, basal joint and base of third joint paler; scutellum conves; elytra dull, with fine crect hairs, 
in the $\delta$ darker at the extrome base, with a transverso shining white band traversing the corium just above the posterior coxæ, bordered with dark brown, and a semiInnate spot on the clavus at its side; there is another similar band just above the cuneus ; cuneus dark brown like the base of the elytra, membrane dusky; in the $q$ each elytron has a triangular white spot, and the globose abdomen is clothed with scattered upright hairs, legs brown, femora and tibiz with erect hairs.

L. $4 \mathrm{~mm}$.

Littlehampton, Woking, Chobham; Weybridge, Dowylas. Dover, C. G. Hall; Mousehold Heath, Norfolk, Edwards; Camber Sandhills, Butler; Pluckley, Kent, Billups; Langport, Dale.

\section{ALLODAPUS, Fieb.}

$$
\text { (Eroticoris, D. } \mathcal{S} \cdot \mathcal{S}_{\text {. }} \text { ) }
$$

Subelongate in the developed form, short and widened posteriorly in the undeveloped, eyes large, very prominent, vertex with a longitudinal impression, antenna of nearly equal thickness throughout; pronotum with a narrow, straight collar, sides sinuate, base emarginate; elytra considerably longer than the abdomen in the macropterous form, truncate at the apex, and about two-thirds the length of the abdomen in the brachypterous; legs slender, with tho femora slightly thickened.

There is only one species in the genus.

A. rufescens, $H$. Schf-Pale brownish red, clothed with long erect hairs, elytra with four white spots. Antennw with the basal joint pale, red at the base, second darker red towards the apex, about equal in length to the third and fourth together, fourth about three-quarters as long as the third; pronotum more or less transversely rugose, base about twice as wide as the anterior margin, sides sinuate, base largely emarginate, scutellum with a 
dark spot at each basal angle; elytra with a triangular spot at the base of the corium, and a quadrate spot above the cuneus, white; in the developed form there is also a small white spot at the apex of the clarus; cuneus and corium between the spots darker, membrane dusky, paler below the apex of the cuneus; legs bright red, apex of the femora darker.

L. $5 \mathrm{~mm}$. (macr.), $3 \frac{1}{2} \mathrm{~mm}$. (bracl.. ).

Rare, on Erict, Reigate Heath, Woking; Lowestoft, Herringtleet, Ewhurst, Surrey, Butler; Scilly Isles, J. E. Mason; Knighton Heath, Thornmoor, York, Dule. Dr. Reuter says it generally occurs in th evening, and this has certainly also been my experience.

\section{HALTICUS, Hahn。}

Very short oval, head flattened posteriorly and overlapping the front margin of the pronotum, eyes very prominent, contiguous to the pronotum, antennæ very long and slender, much longer than the entire insect, rostrum short, stout, reaching to the intermediate coxæ; pronotum short, subtrapeziform; elytra convex, cuneus and membrane much deflected; posterior femora very much thickened, tibia slender; finely spinose. 'There are eight Palæarctic species, of which two have occurred in this country.

(2) 1. Head and pronotum yellow . . . Luteicollis.

(1) 2. Head and pronotum black . . : APTERUS.

H. luteicollis, Panz-Black, shining; head, pronotum except at the extreme base, antenna and legs except the base of the posterior femora, yellow. Face elongate, forehead with three round impressions in a transverse line between the eyes, antenna with the second joint black at the extreme apex, once and a half as long as the third, fourth rather longer than the third; pronotum short, anterior margin about two-thirds as long as the base; elytra shining, black, much wider than the pronotum, sides much rounded, 
clothed in fresh examples with a golden scale-like pubescence which rubs off almost immediately, membrane black ; tarsi black at the apex.

L. $3 \mathrm{~mm}$.

On Galium, Hastings, Bromley; Guestling, Shalford, Ewhurst, Butler; Tilgate, Champion; Bembridge, Isle of Wight, Dale; Llantrissant and Cowbridge, South Wales, Billups.

H. apterus, Limn.-Black, very shining; antenna, apex of femora, tibia and tarsi, pale, terminal joint of tarsi black. Less widened posteriorly than the precerling; pronotum more quadrate, its anterior margin being very littlo shorter than the base; elytra very convex, largely and shallowly punctured, often abbreviated, without golden pubescence, but with very short semi-adpressed black hairs, cuneus and membrane very much deflected; legs with the tibixe very finely spinose.

L. $3 \mathrm{~mm}$. (macr.), $2 . \mathrm{mm}$. (brach.)

Reigate, Charlwood, Herne Bay; Stevenage, Hurst Green, Ewhurst, Shalford, Butler; Chattenden, Tilgate, Champion; Pluckley, Kent, 'T'aff's Well, South Wales, Billups; Glanvilles Wootton, Dale.

\section{STRONGYLOCORIS, Cost.}

(Stiphosoma, Fieb.)

A geuus of short oval, convex species, with very wide heads, of which wo have only two of the eight recorded as Palaarctic, in Britain; the short antenne, which are hardly longer than the head, pronotum and scutellum together, and the flattened lead posteriorly, which fits closely on to the anterior margin of the pronotum, and the short legs, will serve to distinguish it from all the allied genera.

(2) 1. Black, head and legs testaceous . . LEUCOCERALUS.

(1) 2. Ochreous . . . . . LURIDUs, 
S. leucocephalus, Iinn.-Very short oval, black, shining, clothed with very short black hairs; head generally testaceous, but varying to piceous, first joint of antennæ, and legs except the tarsi, testaceous. Head very shining and smooth, viewed from above exceedingly short and broad, second joint of the antenne about equal to the third and fourth together; pronotum largely and rngosely punctured, about as wide as the head in front, very little widened posteriorly, convex, sides rounded, base nearly straight, elytra and scutellum more finely and closely punctured, cuneus and membrane deflected, the former constricted at the base outwardly; tibix with very short black spines.

L. $2 \frac{1}{2} \mathrm{~mm}$.

Scarborough, on Vicia cracce, in July, Wiltinson; Mickleham, Dr. Power; Norfolk, Edwards; Chertsey, Oxshott, Billups; Glanvilles Wootton, Bournemouth, Lulworth, Dale; Pitlochry, Norman; Rannoch, F. B. White.

S. luridus, Fall.-Testaceous or ochreous, somewhat shining, densely clothed with pale hairs. Antennæ blackish brown, apex of the basal joint and centre of the second paler; pronotum sometimes with a dark streak down each side anteriorly; in shape and proportion very like the preceding, but duller, more pubescent, and less largely and more closely punctured.

L. $3 \frac{1}{2} \mathrm{~mm}$.

On Jasione; rare. Hayling Island; Weybridge, Douglas and Scott; Swanage, Marshall.

\section{ORTHOCEPHALUS, Fie.}

$$
\text { (Labops, pars, Reut., Saund., \&·c.) }
$$

Male macropterous, female usually brachypterous, moro rarely macropterous; surface clothed with golden deciduous pubescence; head with the vertex carinated posteriorly, eyes prominent, anteuna reaching to the 
apex of the cuneus, third and fourth joints much thinner than the second, which is slightly thickened towards the apex; pronotum trapezoidal, very slightly conver; posterior femora thickened, tibire elongate, with rather long spines, second joint of posterior tarsi much longer than the first. We have two species in Britain, of the thirteen described by Reuter as Palaarctic.

(2) 1. Black, tibiw, at least the first and second pairs reddish ochreous. . . . SALTATOR.

(1) 2. Legs entirely black, male with the corium inwardly pale . . . MUTABILIs.

L. saltator, ILahn.-Black, tibive of the first and second pairs of legs and sometimes of the third paler, surface densely clothed with black erect hairs and golden scalelike deciduous pubescence; second joint of the antenna not quite so long as the third and fourth together, narrower at the base than the first, but about as thick as that joint at the apex; pronotum in the $\delta$ with the anterior margin about half as long as the base, in the of about two-thirds as long; elytra very long and parallel-sided in the male, sides slightly curved in the developed $q$, membrane black; in the undeveloped $f$ each elytron is rounded posteriorly, reaching nearly to the sixth segment; tibia with fine long spines.

L. $5 \frac{1}{2} \mathrm{~mm}$. (macr.), $5 \mathrm{~mm}$. (brach.).

Not rare; on Trifolium, Ononis, etc. ; generally distributed.

L. mutabilis, Fall.-Male known at once from the preceding by its shorter form, shorter pronotum, less widened behind, the base not being more than once and a half as long as the anterior margin, the ochreous inner half of tho corium, and paler membrane clouded with brown. 'I'he macropterous form of the $q$ is unknown, and the brachypterons form is difficult to distinguish from that of saltutor; it is, however, rather larger and more robust, the pronotum is 
wider and more transverse, and its sides more parallel, and the legs are entirely black.

L. $5 \mathrm{~mm}$.

Chobham, Woking, Hampton Wick, Lowestoft, Barnstaple, Nunton near Salisbury, on Tanacetum, Marshall; Bixley, Norfolk, Edwards; Hurst Green, Butler; Chertsey, Taff's Well, South Wales, Billups; Glanvilles Wootton, Dale; Weybridge, Douglas and Scott; Forres, Pitlochry, Norman.

\section{MACROLOPHUS, Fieb.}

Elongate, delicate in texture, head convex, face nearly vertical, eyes remote from the pronotum, small, situated about midway between the apex and base of the head, sides behind the eyes parallel, antennæ with the second and third joints subequal, rostrum reaching to the posterior coxw; pronotum with rather a long parallel-sided collar, sides sinuate, base raised and largely emarginate ; ely tra parallelsided, membrane fully developed; femora slender, tibize with exceedingly fine spine-like hairs, second joint of the tarsi twice as long as the third.

M. nubilus, $\pi$. Sch.-Green, clothed with fine semierect brown hairs, basal joint of the antennæe, a stripe on each side of the head behind the eye, black, extreme apex of the corium and the last joint of the tarsi brown, antenna reaching to about the apex of the cuneus, pronotum with a strong transverse discal impression, membraue with a transverse cloud above the apex.

L. $3 \frac{1}{2}-4$ m.

Rare; on Stachys sylvatica, Reigate, 'Iunbridge Wells; Battle, Highgate, Barnet, by sweeping, "no Stachys syleatica near," Butler; St. Albans, Leicester, MIarshall; Norfolk, Edwards; Cardiff, Billups; Lewisham, June, on Stachys sylvatica, Douglas and Scott; Pitlochry, Forres, Norman. 
Easily distinguished as a genus by the elongate shape, pale colour, and almost transparent elytra, which are clothed with semi-erect black or brown bairs; the legs also are long and slender, and the femora spotted with black or brown. The female is often and the male sometimes dimorphous. Eyes situated at some distance from the pronotum, head narrowed behind them, antenuæ very variable in lougth; pronotum with a rather long collar and a well-marked transverse discal constriction, base largely and deeply sinuate; elytra in the inacropterous form elongate, parallelsided; femora spotted, tibio with fine spines. There are thirteen species described by Reuter, of which we have seven. This is one of our most difficult genera, the species being very closely allied and similar in general facies.

(6) 1. Antennæ long and slender, reaching beyond the aper of the clavus.

(5) 2. Transverse sulcature of pronotum nearly in the centre.

(4) 3. Darker, second antennal joint pale only in the centre. ERRANs.

(3) 4. Paler, second antenual joint only darker towards the apex . . . EPLOBII.

(2) 5. Transverse sulcature of pronotum behind

(1) 6. Antenna shorter, not reaching to the apex of the clavus.

(10) 7. Head pale, with two dark lines down the midale,

(9) 8. Posterior tibia with long spines and rather long pubescence . . . STACardis.

(8) 9. Posterior tibia with short spines and very short pubescence . . . PaLlidicorisis.

(7) 10. Head black with pale spots.

(12) 11. Pronotum transtersely rugose . . . GLobdurer.

(11) 12. Pronotnm not rugose. . . annulatus.

D. epilobii, Rent.-Greenish ochreous, head and pronotum pale, a spot on the apex of the corium, and sometimes the apex of the cuneus dark, membrane with the nervures dark towards the apex of the cells; basal joint of 
the antenna red, second often dark at the base and apex, third and fourth dark or pale, abdomen green; structurally distinct from errans by the much narrower base of the pronotum, which is hardly twice as long as the anterior margin. 'I'his gives it a distinctly longer and narrower look; the third and fourth joints of the antenna are also shorter in proportion to the second.

L. $5 \mathrm{~mm}$.

Common and probably generally distributed, on Epilobium; it looks quite green in the net.

D. constrictus, Boh.- o macropterous, of dimorphous; may be distinguished from epilolii by its shorter form, the wider pronotum posteriorly, the transverse sulcature of which is placed behind the middle; also by the larger, more prominent eyes, the thinner and longer third and fourth joints of the antennx, which together are distinctly longer than the secoud, and by the pale, not red, basal joint. From eirans the paler colour, the more posteriorly constricted pronotum, and the almost entirely pale cuneus will distinguish it. The brachypterous form of the $q$ closely resembles stachydis, but the long antennæe and legs of this species at once separate it.

I. $4 \mathrm{~mm}$.

Rare; on Symphytum and Rubus iedares according to Reuter; has occurred in this country at Perth on $S_{y / m-}$ phytum, Reuter; at Well in Lincolnshire, J. E. Mason, and at Shiere, Surrey, E. A. Butler.

D. errans, Wolfj.-One of our darker species, head, antennæ, and pronotum mostly black or brown, the latter sometimes paler. Head with a pale streak on each side, and sometimes one in the centre; antennæe about as long as the abdomen, third and fourth joints together about equal to the second, basal joint in the of subequal to the apical joint, shorter than it in the $q$; base and apex of first joint, sometimes the centre of the second, and the base of the third, pale; pronotum very wide posteriorly, base more than 
twico as wide as the anterior margin; discal impression, if anything, in front of the middle;-scutellum dark, with the sides pale; elytra pale ochreous, clothed with thick black hairs, clavus often nearly black, two spots at the apex of the corium, and the apex of the cunens red or black, and sometimes the nerves of the corium black also, membrane hyaline, nervures dark; femora pubescent, spotted with black, tibia with fine spines; beneath varying from black to ochreous.

L. $5 \mathrm{~mm}$.

Generally distributed on Stachys, etc.

As mentioned by Dr. Reuter (Hem. Gymn. Eur.p. 417), I have a few specimens from Penzance differing in the longer antennx, and also in having the pronotum narrower at the base; but I think I shall do well to follow his example and wait for more specimens before describing this form as new. At Ilfracombe in September, 1890, I took two brachypterous females of this species, amongst many of the ordinary form. I do not think this form has been recorded bufore.

D. stachydis, Reut.-Distinguished from any of the preceding by the shorter form and by the shorter antenna and legs, and from errus and constrictus by the uarrower base of the pronotum, which is scarcely twice as wide as the auterior margin; the antenna have the basal joint red at the apex, the second dark at the base and apex, the third and fourth dusky, the former pale at the base, together considerably longer than the second, fourth about two-thirds as long as the third; sides of the head behind the eyes black, vertex with two black lines, apex of the cumeus and nervures of membrane cells red; posterior tibia only alout $2 \frac{1}{4} \mathrm{~mm}$. in length, in constrictus they are nearly 3; both of and of occur brachypterous.

I. $4 \frac{1}{2} \mathrm{~mm}$. (macr.) ; $3 \frac{1}{2} \mathrm{~mm}$. (bracl.)

On Stuchys sylnutica; Reigate, Woking; Barnet, Shalford, Ewhurst, Leith Hill, Butler; Dover, C. G. Hull; 
Colwyn Bay, A. Beaumont; Norfolk, Edwards; Cardiff, Walmer, Oxshott, Ely, Billups; Lincolnshire, J. E. Nason.

D. pallidicornis, Fieb.-Like stachydis in shape, but rather more parallel-sided and broader, and distinguishable from that species as well as from any of the preceding by the comparatively glabrous tibix, the fine pubescence of which is only to be seen through a strong lens; the pronotum also is shorter and broader, the base very wide; the elytra short and wide, parallel-sided; the cuneus broadly brown at the apex; cell-nerves of membrane brown.

L. $4 \mathrm{~mm}$.

On Digitalis; 'Tunbridge Wells, Wimbledon, Esher, Reigate, Champion; St. Albans, Abergavenny, Marshall; Hurst Green, Ewhurst, Barnet, Shalford, Butler; Darenth Wood, Taff's Well, South Wales, "very common on Foxgloves," Billups; Forres, Nurman; Kirkcudbrightshire, Perthshire, Aberdeenshire, Ross-shire, Inverness-shire, ${ }^{\prime}$. B. White.

D. globulifer, Fall.-Elongate oval, clothed with very short black hairs; head black, with a pale spot near each eye; antennæ black, short; pronotum black, varying to ochreous, with the callosities black, collar short, pale, callosities strongly developed, sides nearly straight, surface transversely rugose; scutellum black, with the sides white; elytra short, ochreous or brownish, punctured, sides slightly rounded, apex of cuneus brown, membrane smoky; all the nerves brown; legs short, femora with large black spots, tibix with fine brown spines.

L. $3 \frac{3}{4} \mathrm{~mm}$.

On various plants, Pteris, Dianthus, Lychnis, Silene, Ononis, fide Reuter; Woking, Lowestoft, Southwold, Hastings and Walmer, Billups; Glanvilles Wootton, Dule; Battle, Shalford, Butler; Norfolk, Edwards; Bishops 'Teignton, Leicester, Marshall; Devon, Parfitt; Knnowle, Clacton, Blatch; Forres, Norman; Mickleham, Shirley, Caterham, Champion. 
D. annulatus, Wolff:-The smallest species of the genus. Head black, with three white spots; antennæ short and thick, the base and apex of the first joint, the centre of the second, the base of the third, white; pronotum and elytra ochreous, clothed with coarse black hairs, callosities large, more or less spotted with white, dorsal line white, sides rounded in front, then constricted and straight posteriorly; scutellum black, its dorsal line and a spot on each side white; elytra unicolorons, a spot at the apex of the corium sometimes darker; membrane dusky, with a small brown spot below the apex of the cumeus; femora with large spots, tibia also spotted.

L. $3 \mathrm{~mm}$.

On Ononis, common where it occurs.

Reigate, Herne Bay; Norfolk, Edwards; Wymondley, Deal, Butler; Sandwich, Bishops T'eignton, Mresshall; Barry Island, South Wales, Billups; Glanvilles Wootton, Dale; Caterham, Champion.

\section{CAMPYLONEURA, Fieb.}

Allied to Dicypleus, but distinguishable at once by the larger eyes, which touch the pronotum, and the brighter coloration, as well as by the very fine pale pubescence of its upper suriace, and its unspotted femora. $\delta$ and o macropterous. There is only one European species.

C. virgula, H. Schif.-Elongate, shining. Head black, with two pale spots at the base; antennx, first joint orange yellow, slightly longer than the width of the vertex between the eyes, second black, pale at the extreme apex, third and fourth pale, subequal in length, together slightly longer than the second, basal half of the third reddish brown; pronotnm orange red, collar and base widely white, sides nearly straight; scutellum orange at the base, paler at the aper, basal angles brownish; elytra 


$$
\text { Capside. }
$$

pale ochreous, clarus tinged with brown, cuneus yellow, its apex blood-red, membrane slightly dusky, nervures brown; legs pale, apices of tarsi black.

L. $4 . \mathrm{mm}$.

This very pretty and elegantly-shaped little species is common and generally distributed, occurring on various trees. I have generally found it most commonly on oaks.

\section{CYLLOCORIS, Hahn.}

Our British representatives of this genus are two very dissimilar species, and I feel it rather hard to believe that they should be thus united. One is a rather flat, black, hairy insect, with four elytral spots, which used to be placed under Globicens, from which genus, however, it is clearly distinct; the other a somewhat cylindrical, glabrous, highly-coloured insect. The genus as at present constituted differs from Globiceps, its nearest ally, by the similarity of the two sexes, the longer first joint of the antenna, which is very slightly curved at the base, the shorter rostrum, only reaching to the mesosternum, and the more remote posterior coxæ; there are five species in Reuter's monograph.

(2) 1. Reddish brown, head and parts of the pro-

notum black

(1) 2. Black, with four yellow elytral spots : FLAYONOTATUS.

C. histrionicus, Limn.-Elongate, glabrous, shining. Head black, subglobose, vertex not carinated, basal joint of the antennæ yellow, longer than the head, second black or brownish, once and a quarter as long as the third and fourth together, third trvice and a half as long as the fourth, fourth sometimes red; eyes prominent, not quite touching the pronotum; pronotum black, collar and base more or less widely pale yellow, sides sinuate, base much raised, but only slightly sinuate; scutellum black, apex yellow; elytra brownish, or orange yellow, corium bordering the clavus 
grey, cuneus bright yellow at the base, dusky at the apex; membrane brown, nerve of outer cell yellow at the apex a white spot just below the apex of the cuneus; legs orangeyellow.

L. $7 \mathrm{~mm}$.

This pretty and very variable species is common on oaks, and generally distributed.

C. flavonotatus, Boh. (flavo-quadrimacnelutus, De Gerv, Teuter).-Black, clothed with erect hairs, with four yellow spots on the elytra, basal joint of the antennae and legs testaceous. Head with a stroug curved pale carina on the vertex posteriorly; antennæ with the first joint as long as the head, fourth about a quarter as long as the third; pronotum much widened posteriorly, sides rounded in front, then slightly sinuate to the posterior angles, surface transversely rugose; elytra brown-black, base of the corium nearly to the apex of the clavus, the entire lateral magin and the cuneus except at its apex yellow; membrane brown, a clear spot below the apex of the cumeus; legs testaceous, tarsi brown; beneath black.

L. $7 \mathrm{~mm}$.

I have kept to the name flavonotatus, Boh., as really fiaro-quadrimaculatus, De Geer, is too long to talk about.

On oalis, Chobham, Reigate ; Hastings, Highgate, Butlor; Church Stretton, Blutch; Norfolk, "common on oaks," Edwards; Darenth, Champion; Glanvilles Wootton, Dale; Ashtead Wood, Loughton, March, Cambridge, Llantrissant, Billups; Horrabridge, Bickleigh Vale, Cann IVood, Devon, Bignell; Ireland, Haliday.

\section{ETORHINUS, Fieb.}

Not likely to be confounded with any other British genus except Opthotylus, which it resembles in its uniform green colour, but from which it may be known by the sinuate sides of the promotum, its anterior collar and the 
discal transverse impression; the pronotum is also more convex, and more raised posteriorly. Eyes large, prominent, not quite touching the prountum, vertex carinated posteriorly; elytra long, parallel-sided, both sexes macropterous; femora very long and slender, tibia with fine spines. There is only one species.

FE. angulatus, $F_{u} l l$.-Green; base and apex of first and second anteunal joints and a line along the first beneath, hind angles of pronotum, and extreme base of each tibia, and often a row of spots on each side of the abdomen beneath, black. Antenna with the basal joint as long as the pronotum, and slightly longer than the apical, second and third subequal, second slightly curved; pronotum somewhat campanulate, callosities well developed, transverse sulcature deep, posterior angles slightly raised; elytra elongate, parallel-sided; membrane with the cell-nerves green; tibio slightly darkoned towards the apex, apex of tarsi black.

L. $5 \mathrm{~mm}$.

Common and generally distributed, occurs by beating various trees, especially Salix, Alnus, and Betula.

\section{GLOBICEPS, Latr.}

A well-marked genus, in which nearly all the described species have a tendency to four-spotted elytra. 'The of and $q$ are dissimilar, the $q$ being generally brachypterous, and having the second antennal joint clavate; the head in the male is flattened between the eyes, in the $q$ it is raised, and the head subglobose; pronotum with the sides sinuate, callosities very large and prominent, base slightly sinuate; spines of the tibix scarcely observable. The synonymy of the four-spotted species has been constantly changing, but Dr. Reuter has examined the type specimen of flavomaculatus, Fub., and says that it is what we call selectus, Fieb.; so although I am obliged again to alter our nomencla- 
ture, I hope the alteration will be final. There are nine recognized European species, of which we have three.

(4) 1. Elytra with four yellow spots.

(3) 2. Male, elytra neariy four times as long as its basal width, head highly polished and shining; female, head viewed from in front not very transverse, vertex much raised between the eyes. . . riavomaculatus.

(2) 3. Male, ely tra about three times as long as its basal width, head not very shining; female, head viewed from in front very transverse; vertex only slightly raised. CRUciatus.

(1) 4. Elytra pale whitish, with a greyish brown central band, vertex of male ecarinate - DISPAR.

G. flavomaculatus, Fab. (selectus, D. \&. S.).-Black, clothed with occasional silvery deciduous scale-like hairs, basal joint of the anteanx and legs reddish, elytra with the base of the corium, except the extreme angles, and its lateral margin almost to the cuneus, as well as the base of this latter, ochreous white. Hoad very shining, strongly carinated on the vertex posteriorly in the male, carina complete or sometimes only visible in the centre, in the $?$ very globose; pronotum much widened posteriorly in $\delta$, callosities strongly marked, collar very short, of (brach.) callosities very large, swollen and shining, projecting so as to cause the sides to be much rounded in front and sinuate behind them; elytra in the of very elongate, in the brachypterous of shorter than the abdomen. I do not know the macropterous form; membrane and nervures dark, tibix with scarcely noticeable spines.

L. $6 \mathrm{~mm}$. ơ; $5 \mathrm{~mm}$. q (brach.).

According to Renter, the right-hand forceps of the $\delta$ armature is simple at the heel, and the left-hand is not angulated on its outer edge.

Choblam; Hurst Green (at roots), Butler; Norfolk (rare), Elwarls; Nunton and Cornworthy, Marshall; Devon, Purfitt; Leatherhead, Walmer, Pluckley, Cowbridge, South Wales, Billups; Glanvilles Wootton, Dale; Armagh, Johnson; Eltham, Weybridge, Sanderstead on Umbelliferr, Douglas and Scott. 
G. cruciatus, Reut. (flavomaculatus, D.\& S., eto.; futvipes, Sannd. Syn.)-Exceedingly like the preceding, but smaller ; o less elougate, head less shining, second joint of antennæ shorter, vertex flatter; pronotum wider in front, collar longer; elytra shorter, spots less produced along the lateral margins. o easily distinguished by the less globose head, and smaller less shining pronotal callosities, and consequently less sinuate sides. I have one macropterous $q$, in which the elytra are about as long as the abdomen. Right-hand forceps of of spinulose at the heel, left, strongly angulated on its outer edge.

L. $5 \mathrm{~mm}$.

On Sallows, \&c., not uncommon, Hampton Wick, Deal, Hastings, Chobham; Reigate, Champion; Hurst Green at roots, Butler; Lincoln, Blatch; Forres, Reuter; Dartford Brent, Dougles and Scott.

G. dispar, Boh.-Head, pronotum, and abdomen black, elytra white, nearly transparent, with a wide cloud across the apex of the corium, the apex of the cuneus in the $\sigma$ brown; legs in both sexes and basal joint of the antennæ in the $q$ oclireous. Head not carinated posteriorly in the male, second joint of the antennw very clavate in the o, third joint pale at the base; sides of pronotum sinuate; elytra in the brachypterous of about twice as long as the scutellum, in the macropterous slightly longer than the abdomen; membrano dusky, cell-nerves brown, cells hyaline; tibire with hardly perceptible spines.

L. $4 \mathrm{~mm}$. (macr.), $3 \frac{1}{2} \mathrm{~mm}$. (brach.).

Hatley, Boll; Corton and Fritton, Suffolk, Butler; Earlham, Coxford, Hellesdon, Norfolk, Edwards; Colwyn Bay, Beurmont; Oxshott, Penarth, Billups; Ireland, Haliday.

G. ater, $D . \& S$. - This species still remains a mystery, but from Messrs. Douglas and S'cott's description its leading characters should be:-Black, antennie, third joint with its basal half yellow; corium pitchy black at the base, within the anterior margin a short whitish streak, claval suture narrowly whitish, posterior margin black, cuneus black, 
inner basal angle brownish white, membrane pale brown, legs brownish yellow.

L. $3 \frac{1}{2} \mathrm{~mm}$.

Leicester, Marshall; one specimen q.

\section{MECOMMA, Fieb.}

(Chlamydutus purs, Sannd. Sym.; Sphyracephulus

$$
\text { pars, } 1 . \& . S^{\prime} \text {.) }
$$

Distinguishable from Globiceps and any of the preceding by the absence of the discal transverse sulcature of the pronotum; its nearest ally is the following genus Cyrtorrhinus, trom which the more vertical face and the dissimilarity of the sexes separate it.

M. ambulans, Fall.-Black, shining, clothed with pale hairs, legs pale ochreous, ơ with the elytra also ochreous. Antennæ in the $\delta$ with the second and third joints subequal, in the of with the second joints subclavate, longer than the third, eyes prominent, vertex carinated posteriorly; pronotum trapezoidal, callosities not prominent; elytra elongate, parallel-sided in the $\delta$, ochreous, their margins, especially those of the cuneus, the clavus, and a spot at the outer apical angle of the corium darker, membrane with the nervures brownish. I elytra widened posteriorly, black, membrave with the cell-nerves and cells dark, brach. $q$ with their apices rounded, not covering half the shining black abdomen, tibia with very fine spines.

L. $4 \frac{1}{2} \mathrm{~mm}$. $\delta$; $4 \mathrm{~mm}$. ㅇ macr.; $3 \mathrm{~mm}$. ㅇ brach.

By sweeping amongst rushes, etc., in damp places; generally distributed; macr. o very rare.

\section{CYRTORRHINUS, Fi}

\section{(Chlamydatus pars, Saund. Siyn.; Sphyracephulus} pais, U. $\delta \cdot \mathcal{S}^{*}$.)

Differs from the preceding genus by the less vertical head and the similarity of the males and fewales, other- 
wise I can see no structural characters to separate them. We have three out of the four known European species.

(2) 1. Pronotum black .

(1) 2. Pronotum chiefly pale.

(4) 3. Heal black. . . . . . . ryemeus,

(3) 4. Head pale : : : : : ELAveolus.

C. caricis, Full. - o Elongate, of elongate oval; head, pronotum, and scutellum black, elytra green outwardly, brown towards their suture, legs green or brownish-green. Vertex with a pale spot near each eye; antennæ black, longer than the body; pronotum trapeziform, callosities not prominent, sides slightly sinuate, base nearly straight; elytra parallel-sided $\delta$, sides slightly rounded o $;$; clavus and corium on its inner margin dark in the $\delta$, less so in the of; membrane slightly dusky, cell-nerves green; legs brownish green in $\delta$, green in the $q$, tibiæ with scarcely noticeable spines.

L. $4 \mathrm{~mm} .0$; $3 \frac{1}{3} \mathrm{~mm}$. ㅇ.

Amongst rushes, \&c.; Reigate, Chobham, Wimbledon, Surbiton; Newcastle, Bold; Shalford, Barnet, 'Iunbridge Wells, Butler; Norfolk, Edwards; Devon, Parfitt; Loughton, Chumpion; Byfleet, Oxshott, Holywell, Cardiff, Billups; Glanvilles Wootton, Dale; Forres, Norman; Colvend, Kirkcudbrightshire, F. B. White; Armagh, Johnson.

C. pygmæus, Zett. (Tytthus insignis, D. \&. S.).-Small, oblong-oval, macropterous in both sexes, pale testaceous, clothed with very fine brownish hairs. Head, antenux except the apex of the first joint, and often the pronotum posteriorly-black; eyes large, prominent; antennæ with the third and fourth joints subequal, each about threequarters as long as the second; pronotum transverse, trapeziform, sides nearly straight, base largely sinnate; elytra with the sides slightly ronded, membrane nearly hyaline, tibix with black spines.

L. $21 \frac{1}{2}-3 \mathrm{~mm}$.

At roots of rushes, \&c. in marshes, Chobham, Wimbledon; 
Barnet, Deal, Lowestoft, Fritton, Butler; Norfolk, Edwards; Esher and Freshwater Bay, Pembrokeshire, Marshall; Sandwich, Billups.

C. flaveolus, Reut.-Slightly larger and broader than pygmaus, dimorphous in both sexes, macropterons forms rare; entirely flarous, with the exception of the eyes and antennw, which are black, the latter having the extreme base and apex of the first and the base of the second and third joints pale; surface clothed with fine pale hairs; tibie with very fine brownish spines.

L. 3-4 mm.

Rare ; Coxford, Hellesdon, Ranworth, Norfolk, Edwards ; Fritton, Suffolk, Butler.

\section{ORTHOTYLUS, Fir \%.}

\section{(Litosoma, D. $\{\cdot S$. )}

A genus of closely allied species, mostly of a green colour, although some vary from the rule, and are brown or red; they are mostly elongate oval, the males being in most cases more parallel-sided than the females, although in one section of the genus they are almost alike. The eyes are large and nearly, or in some cases, quite touch the pronotum, the antenne and rostrum vary in length and proportions, the pronotum is transverse and trapeziform, its sides nearly straight, the base straight, sinuate or slightly rounded, disc without a transverse sulcature, both sexes macropterous, tibire with fine spines, wing-cell without a hook-like nerve. We have seventeen British species of the thirty-five recorded by Reuter.

(1) 1. Elytra and pronotum more or less brown, not entirely green or red.

(3) 2. Entire insect olive bromn. . . . FOSCESCENS.

(2) 3. Not entirely olive brown . . Bilineatus.

(1) 4. Elytra and pronotum entirely green (or yellow when faded), or red (rubidus). 
(22) 5. Pubescence of elytra unmixed with black hairs.

(1!1) 6. Cell-nerves of membrane green.

(s) 7. Basal joint of antennæ black beneath. Nassatus.

(i) 8. Basal joint of antenne not black beneath.

(14) 9. Anterior femora with a row of long bristly hairs along their under margin.

(11) 10. Larger and broader, base of pronotum straight. - base of pronotum (10) 11. Elongate, narrow, base of pronotum
widely sinuate.

(13) 12. Basal joint of the antennw shorter than the head, second joint without long exserted hairs

(12) 13. Basal joint of antenna longer than the head, second joint with scattered exserted hairs : withont long bristly

(9) 14. Anterior femora without long bristly hairs beneath.

(16) 15. Vertex carinated, male with the right side of the forceps stipitate and triangularly dilated, its apex truncate, left side with its wider basal portion very convex outwardly, denticulate on its upper margin, produced below into an elongate somewhat curved process

(15) 16. Vertex not carinated, right side of male forceps not truncate, left less convex, not denticulate along its upper margin, apical process straight.

(18) 17. Male, right side of forceps with two somerhat straight-sided processes of unequal length. Female with the apical joint of the antennx considerably longer than the basal . '

(17) 18. Male, right side of forceps with two
short processes of subequal length, much rounded on the under margin. Female, apical joint of the antenna scarcely longer than the basal

MARGINALIS.

DIAPIIANUS.

VIRIDINERVIS.

ochrotricues.

PRASINUS,

(6) 19. Cell-nerves of membrane yeilow.

(21) 20. Small, narrow, very pale yellowish green, elytra very delicate and transparent.

(20) 21. Large, wide, elytra green, not very thin,

(5) 2.:. Pubescence of elytra mixed with black

(24) 20. Cells of membrane green .

(23) 24. Cells not green.

(26) 25. Third and fourth joints of the antenno together shorter than the second.

\section{ScotTr.}

TENELLUS.

FLAVINERVIS,

FLA VOSPARSTS.

ADENOCARII. 
(25) 20. Third and fonrth joints of the antennes together longer than the second.

(iv) 27. Rostrum not reaching to the posterior cosæe, posterior femora scarcely thickened.

(29) 28. Roitrum thicker, reaching slightly beyond the anterior cosa, colour darker green, membrane dark ... .

(23) 29. Rostrum thinner, reaching to the intermediate cora, colour paler green, membrane paler : col por

(27) 30. Rostrum reaching beyond the posterior coxw, posterior femora more or less thickened.

(32) 31. Oblong oval, vertes not carinated, cell nerves yellow . .

(31) 32. Short oval, green or red, vertex strongly carinated, cell-nerves not yellow. Rubidus.

0. fuscescens, $K \boldsymbol{b}$.-Oblong or oval, broad, olive brown, clothed with fine pale and brown hairs. Antenne with the first joint shorter than the fourth, third about two-thirds the length of the second, which is about equal to the third and fourth together; pronotum transverse, callosities well defined; elytra subparallel-sided in the $\delta$, sides curved in the $q$, membrane dusky; tibia with five spines.

L. $4-4 \frac{1}{2} \mathrm{~mm}$.

On firs, July, Forres, Norman.

0. bilineatus, Fall.-Subelongate, greyish or greenish brown; clothed with short pale hairs. Head yellowish, dorsal line, widening anteriorly, brown; antenna black, second joint subequal to the third and fourth together, fourth not half so long as the third; pronotum with the sides sinuate, posterior angles slightly raised, generally with a dark band across the callosities, and the hind angles brown; scutellum yellow, triangularly brown in the centre; elytra subparallelsided; clavus brown, ercept on its outer margin, corium greenish, mor: or less clouded towards the apex; membrane slightly dusky; tibio with fine spines, tarsi black.

L. $5 \mathrm{~mm}$.

On aspens, Wimbledon; Wymondley and Stevenage, 
Butler; Mucliton, Lincolnshire, J. E. Mason; Leicester, Marshall; Kirkcudbrightshire, Perthshire, Aberdeenshire, Ross-shire, and Inverness-shire up to $1500 \mathrm{ft}, F$. B. White; Pitlochry and Forres, Aormen; Braenar, Champion.

0. nassatus, Fal. (striicornis, $K$ b.) - Subrlongate, pale greeu, somerhat transparent, clothed with fine pale hairs, membrane hyaline, strongly iridescent. Antennæ rather short, first joint about as long as the vertex betreen the eyes, black beneath, second joint about as long as the third and fourth together, fourth half as long as the third; pronotum flat, wide posteriorly, sides straight; elytra with the sides subparallel, cell-nerves bright green; tibia with fine spines, anterior femora beneath with long fine hairs.

L. $5 \mathrm{~mm}$.

On oaks and other trees, Wandsworth, Chobham, Bromley; Eltham, Dourglas and Scott; Barnet, Shalford, Butler; Norfolk, Edwards; Well Vale, Lincolnshire, J. E. Mrason; Oxshott, Taff's Well, Sonth Wales, Billups; Glanvilles Wootton, Dale; Forres, Norman; Rannoch, Marshall.

0. diaphanus, $K b$. - Very pale green and transparent, smaller than the preceding. Antennæ short compared to the other species, third and fourth joints together longer than the second, often more or less dusky, third about four-fifths as long as the second, fourth not half so long as the third; vertex marginated; anterior femora beneath with a series of long erect hairs.

L. $4 . \mathrm{mm}$.

On Salix, Bromley: Barnet, Hastings, Bexhill, Bufler; Well, Lincolnshire, on ash, J. E. Mason; Lee, Eltham, Donglas and Scott.

0. viridinervis, $K b$-Darker and rather larger than either of the preceding, from which it may be known by the longer antennx, whose basal joint is as lovg as the head, second shorter than the third and fourth together, third not two-thirds as long as the second, apical joint longer than the basal, second joint with long exserted hair's, vertex of 
the head marginated; anterior femora beneath with a row of long hairs; rostrum reaching to the posterior coxa.

L. $5-6 \mathrm{~mm}$.

On Elme, Sc., Woking; Norfolk, Elwards; Pitlochry, Forres, Norman.

O. prasinus, Fall.-Very like the preceding, but distinguishable on close examination by the immarginate or almost immarginate vertex, the glabrous front femora beneath, the shorter first joint of the antenuæ, which is not so long as the head, the absence of the longer exserted hairs on the second joint, and the shorter rostrum, which reaches only to the intermediate corr ; $\delta$ forceps of left-hand side with its lower margin prodnced into a long straight process at right augles to its stem, right-hand side with two unequal processes, the outer or lower one longest.

Is. $5 \mathrm{~mm}$.

Elms, Norfolk, Elwards; Well Vale, Lincolnshire, J. E. Mason.

0. Scotti, Reut. (vividinervis, D. \&. S.; prasinus, Sannd. Synopsis).-So like prasinus as to be scarcely distinguishablo except by the genital armature of the $\delta$. This in Scotti differs very much in shape from that species, the right side of the forceps having its lower margin very much curved, its upper margin emarginate, with a blunt tooth at the side of the cmargination nearer the base, left side somewhat like that of prasinus, but with a much shorter process. The only other character of importance is the slightly shorter apical joint of the antenna, which is not longer than the basal joint; this in the $q$ is the only character I know of to rely upon.

I. $5 \mathrm{~mm}$.

On Elms, apparently genernlly distributed.

0. ochrotrichus, D. \& S. (propinquns, Reut.) -Very closely allied to the two preceding, from which it may be known in both sexes by its distinctly and somewhat strongly carinated vertex, and in the male by the very differently shaped forceps, tho right side of which is shaped 
like an inverted triangle on a stalk, its upper margin shorter than the sides; the left side, at the base, is very convex outwardly, and its upper margin denticulate, its lower margin produced into a long, curved, somewhat twisted, pointed process. From viridinervis the glabrous femora beneath will distinguish it.

L. $5 \mathrm{~mm}$.

Woking, Surbiton and Chobham on Elms; Ilfracombe; Folkestone on Ononis, Douglas and Scott. The yellow spots on the elytra described by Douglas and Scott are, I believe, due to some irregular development of the green pigment; there are no traces of them in the other specimens that I have seen.

0. tenellus, Fall. (angustus, D. \&. S.)-Narrow, smaller than either of the three preceding, very pale ochreous yellow, elytra nearly transparent, clothed with pale hairs, eyes large and prominent, black, vertex carinated between them; antenne with the third and fourth joints together shorter than the second, fourth about a third as long as the third; legs with a greenish tinge, anterior femora hairy beneath; cell nerves of membrane jellow.

L. $5 \mathrm{~mm}$.

Ash, Oak, Hazel, etc., not rare, and generally distributed.

0. Alavinervis, $K b m$. - Larger than any of the preceding, elongate oval, green, clothed with rather thick pale hairs. Head yellow, basal joint of antenur black in the $\sigma^{*}$, third and fourth together about as long as the second, third not twice so long as the fourth; pronotum trapeziform, the sides nearly straight, the base slightly rounded at its sides, sinuate in the middle; base of scutellum and lateral margins of the elytra yellow, membrane dark, its nerve cells yellow; legs yellowish, apices of tibir and tarsi dark; male with the right side of the genital forceps three-pronged.

L. $5 \frac{1}{2}-6 \mathrm{~mm}$.

On Salix; Woking, Esher, Hastings, Bromley; Shalford, Butler; Norfolk, Fdwards; Cornworthy, Marshall; 
Forest Hill, Champion; Glanvilles Wootton, Dule; Walk. ham Valley and Bickleigh Vale, Devon, Bignell.

0. marginalis, Reut. (nassatus, Full et Auct.)-Very like flavinervis, but rather longer; basal joint of the autenna pale in both sexes; membrane scarcely dusky, nervures green; male with the right side of the genital forceps not three-pronged, but the left side produced into two long prongs, which are very conspicuous.

L. $6-6 \frac{1}{\mathrm{~mm}}$.

On Salix, common.

O. adenocarpi, Perr. (Douglasi, Saund.).-Of a rather bright pale yellowish green, clothed with pale and black hairs intermixed, pale hairs largely predominant, black hairs easily rubbed off. Antennæ testaceous, third and fourth joints together shorter than the second, third joint about half as long as the second, fourth two-thirds as long as the third, rostrum reaching to the intermediate coxa; pronotum transverse, trapeziform, sides and base nearly straight; elytra subparallel-sided $\delta$, slightly rounded $q$, membrane slightly dusky, nervures pale yellowish white; tibie with dark spines.

L. $5 \mathrm{~mm} .0$, $4 . \mathrm{mm}$. $q$.

On Broom, Woking, Chobham; Plumstead, Billups; Wcybridge, Champion; Shalford, Butler; Perth, lieuter; Forres, Norman.

O. chloropterus, Klm. (concolor, Saund. Synops, D. \&. $S . ; \quad \delta=$ virescen., $D . \& S^{\circ}$ ). - Very like the preceding, but of a darker green and with the membrane much darker, its nervures almost concolorons. The third and fourth joints of the antenna are much longer taken together than the second, the third being nearly as long as the second, and the fourth not quite a third as long as the third; the black hairs on the surface of the elytra are also much more abundant; rostrum short and thick, only reaching to just beyond the anterior coxx.

L. $5 \mathrm{~mm} . \delta^{\pi}, 4 \frac{1}{2} \mathrm{~mm} .+$. 
Common, generally distributed where Broom occurs.

0. concolor, KL.-Sinaller, paler, and of a rather bluer green in colour than either of the preceding, though more like adenocarpi in this respect; third and fourth joints of the antenne together slightly longer than the second, third about four-fifths as long as the second, fourth about a quarter as long as the third; rostrum slender, reaching to the intermediate coxio; elytra with shining white hairs, which are easily rubbed off, and with longer fine black ones intermixed; membrane much paler than in chloropterus, its nervures yellowish.

L. 4-4主 $\mathrm{mm}$.

On Broom, Woking ; Forres and Perth, Renter ; Norfolk, Elwards; March, Cambs., Billups.

I have often had this and the tro preceding species in my umbrella at once, and by the colour alone one could separate them. Chloropterus is the dark green one, chlenocarpi the yellowish-green one, and concolor the whitish or bluish-green one; but immature examples are puzzling.

0. Hlavosparsus, Suhll. (prasinus, D. \& S.).-Bright green, clothed with black hairs, interspersed on the elytra with small paler spots and patches of bright silvery scalelike hairs, cells of the membrane green. Antennæ very long and slender, second and third joints subequal; pronotum very transverse, sides nearly straight; elytra parallelsided in the $\vec{\delta}$, its sides slightly rounded in the of; legs slightly paler.

L. $4 \mathrm{~mm}$.

On chenopodiaceous plants; the spots after death are often quite lost; Lowestoft, Hastings, Littlehampton; Bexhill, Pegrell Bay, Corton, Suffolk, Butler; Devon, Parfitt; Hunstanton and Brancaster, Edwards; Harwich, Waltonon-Naze, Sheppey, Champion; Byfleet and Llantrissant, Billups; Southampton, Lee, Donglus and Scott.

0. rubidus, Put. (var. Moncreatii, D. \&. S.).--Short, oval, dull red or (var. Moncreaffi) green, clothed with black hairs 
and short silvery ones which are easily rubbed off. Head and pronotum wide and transverse, antenne with the third and fourth joints together longer than the secoud, third about three-cuarters as long as the second; rostrum reaching to the posterier coxro. Elytra with its sides rounded, membrane slightly dusky; legs with the posterior femora thickened, tibix with fine spiues.

L. $3-3 \frac{1}{2} \mathrm{~mm}$.

In salt marshes, on Arenaria, Sulsola, etc, Hayling Island; Portsmouth, Moncreaft; Lymington, Salterns and Chesil Beach, Dale; Dawlish Warren, Biynell; Yarmouth and Wells, Norfolk, Edwards; Rye, Pegwell Bay, Butler.

0. ericetorum, Fall.-Bright green, shining, clothed with black hairs, sides of the corium, cuneus, and nervures of membrane yellow; antenuæ loug, third joint about threequarters as long as the second, fourth about half as long as the third, rostrum reaching to beyond the posterior coxx; pronotum short, callosities strongly marked; elytra parallel sided $\delta$, sides rounded, converging to the apex of the membrane which is narrow, giving the elytra rather an acuminate shape in the + , membrane dusky, cell nerves yellow; posterior femora strongly incrassated.

L. 3-3! $\mathrm{mm}$.

Common on Erica and generally distributed.

HYPSITYLUS, Fieb.

Closely allied to Orthotylus, but distinguished by the peculiar form of the rostrum, the third joint of which is widened at its apex, and the fourth widened at its base, so as to give the organ a club-shaped appearance. 'L'here are only two European species, of which we have one.

H. bicolor, D. $\&$. S. (Orthotylus chloropterus, Saund. Synopsis.).-Dull greyish-green, clothed with black and slvery hairs intermixed, silvery hairs dense on the head; head, pronotum, clavus, and corium at its inner apical angles 


\section{Capsida.}

brownish in the of, membrane dark. Vertex very wide, in the $\delta$ trice, and in the of three times as wide as each eye, antennx brownish, third and fourth joints together longer than the second; pronotum very wide in front, sides nearly straight; elytra long and parallel-sided in the of. short with the sides slightly rounded in the + ; tibia with fine spines.

L. $413 \delta^{\pi}, 3 \frac{1}{2}$ ㅇ․

On Ulex, common, and probably widely distributed. It has been recorded from Reigate, Woking, Chobbam; Hastings, Battle, Hurst Green, Ewhurst, Shalford, Butlrw; Norfolk, Eduards; Bewdley, Blatch; Oxshott, Bithus ; Glanvilles Wootton, Dale.

\section{MALACOCORIS, Fieb.}

Elongate, exceedingly thin in texture, and transparent, elytra with green marbling, eyes prominent, not touching the pronotum, sides of the head sivollen, and rounded behind them, third and fourth joints of the very slender antennæ together longer than the second, pronotum with the callosities strongly defined, sides straight, base deeply sinuate, cells of the membrane green apically, legs very slender. Unlike any other British genus, but allied to Orthotylus. 'There is only one species.

M. chlorizans, Fall.-Shining, elongate, very pale, transparent, whitish green, clothed with fine upright hairs, elytra with darker green spots, membrane hyaline, cells green round their apical nervure. Eyes small, prominent, remote from the pronotum, basal joint of the antennæ black beneath, second black at the extreme base; pronotum shaped as above; elytra elongate, parallel-sided; tibie with fine hair-like spines.

L. $4 \frac{1}{2}-\overline{\mathrm{m} m}$.

This most delicate and beautiful little species is far from 
rare on hazel; it occurs also on ash, alder, clm, lime, birch, and sullows, fide lieuter; it is generally distributed.

\section{LOXOPS, Fieb.}

Orat, flat, broader than the allied genera, and in form more like a Psallus. Head with the eyes swall and not prominent, projecting very littlo beyond the lateral margins of the pronotum, antenna with the first joint rather densely hairy, second very long, once and three-quarters as long as the third and fourth together; rostrum reaching to tho iutermediate coxre, pronotum trapezoidal, transverse, clytra parallel-sided, tibia with very long hair-like spines. 'I'here is only one species.

L. coccineus, Mey.-Ochreous, mottled with red or in some specimens mostly red. Head ochreous, a lime down the centre red, antenux reddish; pronotum ochreous, the sides red or brown, and a narrow dorsal line red, lateral margin straight, base slightly sinuate; scutellum ochreous, its sides red; elytra ochreous with red markings, or red with ochreous spots, or in some dark males almost entirely hrownish red, the laterul margin always darkest, membrane slightly dusky, cell nerves red; beneath and legs ochreous, femora red at the apex.

L. $4 \frac{1}{2} \mathrm{~mm}$.

On Ash, Reigate, Hastings, Chobham; Rarnet, Shalford, Sevenoaks, Butlur; Norfolk, Eluards; St. Albans, Marshull; Exeter, Parfitt; Oxshott, and Tati's Well, South Wales, Billups; Walkham Valley, Bickleigh Vale, Shaughbridge, Devon, Bignell.

\section{HETEROTOMA, Latr.}

Subelongate, rather flat, eyes large, basal joint of the antenne swollen, densely hairy, but not compressed, second compressed, densely hairy along the sides, and very wide, about oue-lifth as wide as its length, and wider than the vertex between the eyes, and like the vertex wider in 
the of than in the o. Gradually narrowed at the base and apex, third and fourth very slender and short, subequal; pronotum subtrapezoidal; elytra with the membrane towards its outer edge dark and subrugose, and the wing also rugose in the same relative position. I am not aware of this character occurring in any other genus.

We have only one species in England; three occur on the Continent.

H. merioptera, Scop.-_Shining, brown, clothed with fine brown hairs intermixed with short white pubescence, easily rubbed off, vertex in the oslightly wider than either eye, in the $q$ once and a half as wide, for form of antennx see generic characters; pronotum with the sides slightly sinuate; elytra parallel-sided in the o ${ }^{\star}$, sides slightly rounded q, membrane dusky, a white spot below the cuneus, followed by the dark rugose stripe mentioned above; legs green or yellowish, apex of tarsi black.

L. $5 \mathrm{~mm}$.

Common on nettles, etc., and generally distributed.

\section{HETEROCOR DYLUS, Fieb.}

Oblong-oval or oval, black, clothed with very short black-brown hairs, and with white scale-like pulbescence. Vertex of the head carinated, antenna with the second joint elongate, fusiform in the $q$ of genista, third and fourth together shorter than the second; pronotum trapeziform, its posterior angles rounded; elytra with the sides subparallel $\delta$, or rounded $f$; tibio ontwardly with hardly-perceptible spines. We have two British species of the seven European. Parrulus, lient., has occurred in the Channel Islands, and should be looked for here; it may be known by its smaller size.

(2) 1. Entirely black; female, second antennal joint

(1) 2. Tibiro testaceous; female, second antennal joint simple? 
H. genistæ, Scop. (uricolor, IIahn; leptocerus, D. S. S.). -Dull black, densely clothed with white scale-like pubescence. Antenne with the second joint in the of slightly thickened towards the apex, about once and a quarter as long as the third and fourth together, strongly fusiform in the $f$; pronotum transverse, tripeziform, base about twice as wide as the anterior margin; elytra with the cuneus and membrane in the $q$ much deflected, membrano black, white just along the edge of the cuneus; legs entirely black.

I. $4 \frac{1}{2} \mathrm{~mm}$.

On Broom, Hastings; Northumborland, Bold; Tonbridge, Bluteh; Fairlight, Hurst Green, Butler; Cliffs Milford Haven, Marshull; Norfolk, Edwurls; Tilgate, Champion; Glanvilles Wootton, Dale; Carditt, Billups; Colvend, Kirkendbrightshire on Geniste tinctoria, $F . B$. White.

H. tibialis, Hahn.-Tike the preceding in colour, but rather longer in form and larger, with the tibix reddishtestaceous; second joint of the antennre in the $\delta$ not thickened towards the apex, once and a half as long as the third and fourth together; simple also in the $q$, squamous hairs less white, rather yellowish; pronotum not so much widened posteriorly, base hardly twice as long as the anterior margin; elytra rather longer, and in the $q$ not so much deflected posteriorly.

L. $5-5 \frac{1}{2} \mathrm{~mm}$.

Common on Broom, and generally distributed.

ONYCHOMENOS, Reut.

$$
\text { (Oncotylus, pars Fieb.) }
$$

Subelongate, clothed with fine, very short, regular, pale hairs; eyes prominent, rostrum reaching to the intermediate coxis; pronotum with the sides sinuate, base sinnate, rounded towards the angles; tibia with vory fine dark 
spines; arolia as long as the claws and attached to them throughont their length.

There is only one species.

0. decolor, Fall.-Grey or yellowish-grey, sometimes with a brownish tint, clothed with fine short semi-erect hairs. Head with a spot at the base more or less continued towards the apex, yellowish; pronotum transverse, with a brownish band across the callosities; scutellum with a yellow spot at each basal angle; elytra more or less widely pale along their lateral margins, which are sub-parallel in the male, slightly rounded in the $q$, membrane smoky, nervures pale; legs with the extreme apex of the tibie and the tarsi black; abdomen ochreous, more or less banded with grey.

L. $5 \mathrm{~mm}$.

13y sweeping, common where it occurs, Wandsworth, Hastings, Southwold, Chobham; Tilgate, Chattenden, Champion; Bexhill, Tunbridge Wells, Deal, Ewhurst, Shalford, Butler; Norfolk, Edwards; Chertsey, Deal, Cowbridge and Taff's Well South Wales, Bitlups; Glanvilles Wootton, Dale; Eltham, Dartford Brent, Douglas and Scott.

ONCOTYLUS, Fieb.

\section{(Anoterops, Fieb.)}

Our one British species of this genus may be known at once from its allies by its black-spotted tibie, but the distinctive characters of the genus depend on the truncate, not sinuate base of the pronotum, and the long arolia extending almost to three-quarters the length of the clars, the claws themselves are long and narrow, and very slightly curved. There are thirteen species recorded by Puton.

0. viridiflavus, Goeze (sctulosus, Mey.).- $0^{*}$ subelongate, of elongate oval; dull greyish-green, clothed with black hairs. Head and pronotum jellowish, the former with several round spots, and the central lobe of the face black, the latter with a transverse spot behind each callosity, 
the posterior angles and a transverse spot on the base at each side black; eyes prominent, not touching the pronotum; autenno with the second joint slender, subequal to the third and fourth together" scutellum with the sides black; elytra elongate, parallel-sided in the $\delta$, shorter and with curved sides in the $q$, brownish-green, nerves paler, membrane dark, nervures whitish; femora freckled with black; tibiw with black spots and fine short black spines, also black at the apex; tarsi long and thin, black; abdomen greenish, terminal segments in the of spotted with black above.

L. $8 \mathrm{~mm}$.

On Centaurea; Charlwood, near Reigate; Battle, Dallington Forest, Sevenoals, Stevenagre, Ewhurst, Lowestuft, Butler; I'ilgate, Chattenden, Champion; Hurst IVood, Tunbridge Wells, Douylas and Scott.

\section{MACROTYLUS, Fieb.}

(Macrocoleus, pars. D. S. S., Saund., etc.).

May be known by its very short, strongly-curved clarvs, which are produced at the base into an acute tooth; the shortness of the claws is a very well marked character, the tarsi at first sight looking almost as if the claws were absent; rostrum reaching to beyond the posterior coxie, npper surface clothed with black hairs, which are easily rubbed off; tibire, except the posterior pair in Paykullii, with hardly-distinguishable spines on their outer edge. There are thirteen species recorded by Puton, of which we have two in Britain.

(2) 1. Larger, $5.5 \frac{1}{2} \mathrm{~mm}$; elytra grey, evenly clothed with black hairs . . . . SOLITARIUS.

(1) 2. Smaller, $3 \frac{1}{3} \times 4$ mm.; elytra green, with patches of black hairs . . . . PAYKULLI.

M. solitarius, Mey.-Greyish-greon, densely clothed with black hairs, elongate-oval. Antenux with the second joint once and a quarter as long as the third, dark at the 
base and aper, and distinctly thicker than the third, fourth about a third as long as the third; pronotum mnch widened posteriorly, base more than twice as long as the anterior margin, sides nearly straight; scutellum convex; elytra with the nerves and the cunens at tho base slightly paler, membrane dusky, with a darker spot just below the cuneus, set off by a hyaline one above and beneath it; cells darker, their nerves white; legs clothed with black hairs.

L. 5-5 $\frac{1}{2} \mathrm{~mm}$.

On Stachys ; Reigate; Shiere, Capron; near Addington on Ononis, Douglas and Scott; Hurst Green, Ewhurst, Shalford, Butler; Mickleham, Power; Caterham, Champion.

M. Paykullii, Fall.-Green, oblong-oval, clothed with thick black hairs, disposed on the elytra in irregular patches, head sometimes dark at the sides. Antennx with the first joint and the base of the second more or less dark, third joint about two thirds as long as the second; pronotum with the anterior margin half as long or more than the base; sides nearly straight, callosities and a dorsal line in the of sometimes nearly black; membrane dusky, nerves vividly white, a quadrate spot-below the cuneus touching the lateral margin black, with hyaline surroundings; legs clothed with black hairs, posterior tibia with fine black spines.

L. $3 \frac{1}{2}-4 \mathrm{~mm}$.

On Ononis, genorally distributed in the South of England.

\section{CONOSTETHUS, Fieb.}

Sub-elongate, clothed with exceedingly short, hardly noticeable pubescence; head short, eyes prominent, vertex with two dark spots in all our species; pronotum short and transverse, with the sides sinuate, base not much wider than the anterior margin, sinuate, callosities transverse and 
very strongly marked; elytra widest at the base in the $\delta$, and gradually narrowed posteriorly, in the $q$ either widest in the middle or with the sides sub-parallel to the middlo and then converging to the apex, cuneus long and narrow, anterior femora, especially in the $\delta$, bent invards; tibia with fine black spines; clarvs elongate; arolia short. Wo have three out of the four European species.

(4) 1. Third joint of antenux longer than the second and slightly curved.

(3) 2. Antennie lonser, the third joint more than twice as long as the fourth in the male, twice as loug in the female.

(2) 3. Antenne shorter, the third joint abont twice as long as the fourth in the male, not twice its length in the female. .

(1) 4. Third joint of antennix straight, shorter than the second . . Roseus.

C. salinus, Sahlb. (griseus, D. \& S.).-Yellowish-grey, head yellow, with two dark spots on the vertex, auteunie very long, thick and black in the $\delta$, shorter, thimuer and brownish in the $q$, with the basal joint pale, third joint curved, distinctly longer in both sexes than the second; pronotum with the sides sinuate, its posterior angles produced and somewhat reflesed, base deeply sinuate in the middle, rounded near the angles, callosities darker, lateral margins and dorsal line pale; scutellum with a pale dorsal line or entirely pale; elytra elongate $\delta$, or with the sides rounded + , lateral margins and cumeus pale, membrane dusky, extending beyond the apex of the abdomen, or about to it in the brachypterous form; legs pale, tarsi dark.

L. $4 \frac{3}{4} \mathrm{~mm} \cdot \delta, 4 \frac{1}{4} \mathrm{~mm}$. ․

Gravesend, on Arenaria maritima, Dr. Power; Hunstanton, Norfolk, Ehwards; Whitstable, Champion.

C. brevis, Rent. - Very like the above, but shorter, with shorter antennæ, the second joint in the of not being more than once and a quarter the width of the head across the eyes, and scarcely longer than the width between the 
eyes in the $q$; the elytra are distinctly shorter in proportion to their width, and in the brachypterous of do not cover the apex of the abdomen; legs shorter and somewhat stonter.

L. $4 \mathrm{~mm}$. $8,3 \frac{\mathrm{mm}}{\mathrm{m}}$. ㅇ

Saline damp places on the shore near Forres, Reuter.

C, roseus, Fall.-About the size of trevis, but recognizable at once by the slender antenne and the pink-brown or pink striped elytra. Head and pronotum in the of grey, or in the of green, lateral margins and dorsal line of the latter pale; antennx with the third joint shorter than the second; pronotum very transverse, sides and base sinuate; callosities very large, with a deep impression behind them; scutellum grey or green, with a pale dorsal line; elytra elongate, widest at the base in the $f$, with the clavus and corium inwardly pinkish-brown, parallel-sided to about the middle $q$, pink on the clavus and corium inwardly, in both sexes pale whitish along the lateral margin; cuneus pale; legs pale, tarsi darker.

L. $3 \frac{1}{2}-4 \mathrm{~mm}$.

Common, but local, by sweeping in dry places, Reigate, Coombe Wood, Hampton Wick, Woking; Norfolk, Edwards; Epping Forest, Marshall; Weybridge, Champion; Oxshott, Billups; Eltham, Douglas and Scott; Scarborough, Willinson.

\section{HOPLOMACHUS, Fieb.}

Oral, very closely allied both to Macrotylus and Macrocoleus, from both of which it differs in the longer apical joint of the tarsi, which is subequal to the second, and from the former also by the longer claws, and from the latter by the more curved form and stronger basal tooth of the claws. 'I'here is only one species, whose black and brown colour is unlike that of any of its neighbours.

H. Thunbergii, Fall.-Durface densely clothed with 
black hairs; head black, a tmanserse spot on the vertex and a longitudinal spot on the face, sometimes united, yellow; antenna black, second joint sometimes paler, in the of much thicker, in the of scarcely thicker than the third, nearly as long as the third and fourth together; pronotum greenish-brown, callosities black, dorsal line pale, sides nearly straight; scutellum with the dorsal line and a spot on each side often pale, and often with a black transverse line near the base; elytra brownish, the margins, nerves, and sutures paler, membrane dark, the nervures pale whitish ; legs brownish, femora spotted with black towards the apex, tibire at the extreme apes and the tarsi black.

L. 4-4. $\mathrm{mm}$.

On Iieracium Pilosella, Chobham; Darenth Wood, Billups; Knighton Heath, Dale; Bewdley Forest, on Hieracinm Blutch; Boxley Hills, Kent, Wrshall; Langstone Point Dawlish, among Anthyllis and Ononis, I'urjitt; Reigate.

\section{MACROCOLEUS, Fieb.}

$$
\text { (Tiniceplatus, Fieb.) }
$$

Under this genus I have included Macrocoleus and Tinicephalus, which Dr. Reuter maintains as distinct. They differ mainly in the form of the xyphus. Only one of our species, hortulanus, belongs to Tinicephalus, and I think it is better to treat the latter as a subgenus of Macrocoleus. 'The genus, as thus considered, may be known from its congeners by its long claws, oval shape, and the form of the posterior tarsi, the second joint of which is longer than the third, the lateral margins of the pronotum are not acute, and in our British species the rostrum reaches to about the posterior corn; all the tibire have black spines. We have three species of the nineteen recorded by Puton.

(4) 1. Xyphns concare, acutely margined, surface clothed with black and paler hairs intermixed, or with black ouly. (Subg. Vacroculeus.) 


\section{Capsida.}

(3) 2. Clothed with soft pale pubescence mixed with fine dark hairs . . . Molticults,

(2) 3. Clothed with thick black bairs . . . TANACETI.

(1) 4. Xyphins convex, immarginate, surface clothed with pale and dark hairs mixed. (Subg. Tinicephaltes.) . . . . . . HORTLLANUS.

M. molliculus, Full.-Greyish-green, clothed with fine soft pale and brown hairs intermixed, elongate oval $\sigma^{*}$, or oval o, second joint of the antenna thickoned in the $\delta$, shorter than the third and fourth together; pronotum transverse, sides nearly straight, base twice as wide $\sigma^{2}$, or once and a half $q$, as the anterior margin, base nearly straight; elytra with the clavus cuneus, and a central band more or less brown, membrane slightly dusky, with a darker spot below the apex of the cuneus, nervures pale; tibio with black spines, tarsi slender, black.

I. 4-5 mm.

On Tanacetum and other plants, not rare, and widely distributed.

M. tanaceti, Fall.-Very like molliculus, but of a yellower colour, as a rule, although I have males nearly as green as that species; the thick black hairs, however, with which the entire surface of the insect is densely clothed will at once distinguish it; in the o the elytra have rarely any darker band; the anterior coxa and femora each bear a row of black spines, which in molliculus are represented by pale setæ.

L. $4 \frac{1}{3}-5 \frac{1}{2} \mathrm{~mm}$.

On Tunacetum, Chobham; on Achillea, Surbiton; Shalford, Butler; near Exeter, Parfitt; Instow, North Devon, abundant, Fowler.

M. hortulanus, Mey. - Smaller than either of the preceding, brownish green, clothed with black and paler hairs intermixed; head and antennx yellowish or yellowishgreen; pronotum dull green, fading to yellowish, in the male with a V-shaped dark mark between the callosities, sides nearly straight, base slightly sinuate; elytra dusky 
green, nerves rather paler, clavus and corium inwardly slightly darker, membrane dusky, nervures pale whitish; femora freckled with a few darker spots nen the apex; tibia with black spines, apex of the tarsi black.

L. $3 \frac{1}{3}-4 \mathrm{~nm}$.

On Ononis, Reigate Hill ; on Helianthemum, Tring Hills, Herts, P'iffurd; Caterham, Champion; Lowestoft, Thouless; Darenth Wood, Mickleham; Pitlochry, Norman.

\section{AMBLYTYLUS, Fieb.}

A genus which may be known from Macrocoleus, its nearest ally, by the slightly-reflexed sides of the pronotum, and in our British species by the long rostrum, which extends beyond the posterior coxw, and by the form of the head, which is longer and less declivous. We have three British species of the seven recorded by Dr. Puton.

(2) 1. Membrane milliy white, with a brown spot across the apex of the cells . DELicatus.

(1) 2. Membrane more or less dusky, unspotted.

(4) 3. Male and female nearly similar in form, densely

(3) 4. Male much narrower than the female, clothed with pale hairs. . . Brevicolis.

A. delicatus, Perr.-o narrow, subelongate, $q$ suboval, pale yellowish green, clothed with very fine whitish hairs and occasional longer brown bristles; head green, about as long as wide, second joint slightly longer than the third, and in the $\delta^{7}$ much thicker; pronotum green in front, ochreous posteriorly, anterior margin rather more than half as long as the base, sides slightly raised in front; elytra pale ochreous, inclining to green on the clavus, cuneus and apex of the corium browuish, membrane milky white, nervures pale, cells brown across their apices, and a brown band extends from the apex of the cuneus to that of the larger cell; abdomen green; tibia with pale brownish spines.

L. $4 \frac{1}{2}-5 \mathrm{~mm}$. 
On Gnaphatium germaniem, Woking, 1888. The actual locality has been destroyed, and I bave looked for it every year since within a ferr yards of where it occurred, but withont success.

A. brevicollis, Fieb.—o elongate oval, greenish grey; q oval, ochreous; both sexes clothed with pale hairs. Head slightly longer than the pronotum, greenish in the of, ochreous in the $q$, second joint of the antenux not quite so Iong as the third and fourth together, thickened in the os; pronotum in the o greenish grey on the dise, inclining to green round the callosities and to ochreous at the sides, in the o ochreous, slightly tinged with green, base about once and a half as long as the anterior margin, sides slightly sinuate, raised; elytra with the sides subparallel of, or rounded $q$, ochreous, with a dark greyish shado covering the clavus and inner portion of the corium, membrane dusky, cells rather darker in most specimens, nerves pale; femora with a fer dark spots near the apex.

L. 4- $4 \frac{1}{2} \mathrm{~mm}$.

By sweeping grass, \&c., Woking, Chobham, and probably elsewhere, but very likely mixed with affinis, or the of possibly mistaken for Ouychumenus decolor, which it somewhat resembles.

A. affinis, Fieb.-Very like the preceding, but larger, ochreous, without decided green tints in either sex, both sezes suboval in form, and densely clothed with blackish brown hairs, male darker than the female; the pronotum, except the dorsal line and lateral margins, and the elytra between the nervures, often entirely greyish brown; in the ot the entire insect is generally ochreous, in the $\sigma^{\pi}$ the abdomen is black above. Dr. Reuter gives this character to both sexes, but in all my females the abdomen is pale above except at the extreme base.

L. $5 \mathrm{~mm}$.

By sweeping grass, \&c., generally in dry places, Woking, Reigate, Hampton Wick, Tunbridge Wells; Eltham, Douglas 
\&. Scott; Ashtead, Champion; Hurst Green, Battle, Ewhurst, at roots, Thutler; Norfolk, Etwarts; Lee, Billups.

\section{HARPOCERA, Curt.}

This curious genus, our British species of which is as large as a Culocoris, may be at once known by the form of its antenna; these in the of have the second joint about as long as the first, bent and angularly produced at the apex on the under side, and the third joint bent, and much longer than the second; in the of the second joint is more than twice as long as the first and simple, the third is bent and much longer than the second; rostrum only reaching to the anterior coxio the male is narrower than the female, and its front tibia are very long and curved, the intermediate and posterior pairs slightly so, in the o the posterior pair, ouly, show a slight curvature; all the pairs with black spots and spines.

H. thoracica, Full.-Head black, often with a central stripe, and the transverse carina of the vertex, white; antenua with the first and second joints generally pale, more or less freckled with brown, third and fourth darker in the 우 ; pronotum with the base in the of more than twice, in the $q$ more than four times, as long as the anterior margin, sides simuate $\delta$, rounded $q$, base sinuate in both sexes, colour black, with the extreme base, and a dorsal line, more or less pale; varying to ochreous, with a spot across the callosities only, black; scutellum brown, its apex pale; elytra brown, varying to ochreous, cuneus always brown, pale at the base; legs reddish testaceous; posterior femora dark at the apex; tibir paler, their extreme apices and the tarsi black; beneath pale, or with the sides and the apex of the abdomen black.

L. $7 \mathrm{~mm}$.

On oaks, generally distributed, but rarely very abundant. 


\section{BYRSOPTERA, Spil.}

Quite distinct from any of the allied genera, and more closely resembling Hecomma, from which, however, the hook-like merve of the wing-cell will distinguish it at once. $o$ macropterous; $f$, as far as $I$ linow, always bracypterous. of in form like a narrow Mecommu; head nearly as wide as the base of the pronotum, anteune slender, rostrum reaching to the posterior cosa; pronotum with the sides and base sinuate; elytra elongate, parallel-sided. of with the pronotum somewhat cylinarical, its sides rounded in front and only slightly divergent posteriorly; elytra in one piece, very convex, widest posteriorly, their hind margin rounded; tibire in both sexes with very fine spines.

B. rufifrons, Fall.-Black-brown, clothed with very fine pale hairs, elytra paler in the $\delta$, head red in the $q$. Antennæ with the first and second joints black in the 0 , the apex of the former sometimes paler, second in the female pale, with the extreme base and apex widely black, third and fourth joints very slender and pale in both sexes; 8 with the cuneus of the elytra pale, elytra in the o not quite covering the very shining abdomen, three times the width of the pronotum in their widest part; legs very pale testaceous in both sexes.

L. $4 \frac{1}{\frac{1}{2}} \mathrm{~mm}$. $\delta, 8 \frac{1}{2} \mathrm{~mm}$. .

By sweeping, generally distributed in the South of England.

\section{PHYLUS, Hahn。}

Macropterous in both sexes, rather flat and parallel-sided, eyes large, head not nearly so wide as the base of the pronotum, second joint of the antenna subequal to the third and fourth together; pronotum trapezoidal, sides straight, base slightly sinuate; ely tra elougate, more than three times as long as wide; legs slender, tibir with fine spines.

We have three British species of the five that occur in Europe, etc.

$$
x 2
$$


(1) 1. Pale orange-yellow, membrane clear.

(3) 2. Head and under-side pale. PALitcers.

(2) 3. Head and underside black . . . Melavocertratos,

(1) 4. Brown or greyish-brown, sometimes nearly black . . . CORYLI.

P. palliceps, Firb.-Shining, entirely pale orangeyellow or flavous, clothed with pale yellow hairs; membrano clear or sometimes with a slightly darker apical cloud.

L. $6 \mathrm{~mm}$.

On outis; not quite so common as the following, but often occurring with it.

P. melanocephalus, Linn.-Only differs from the above, as far as I am able to discern, by the black head and black underside, and also, as Reuter points out, by the extreme base of the first antennal joint being black or fuscous.

L. $6 \mathrm{~mm}$.

On outis; common and generally distributed.

P. coryli, Linn.(var. avellana; II. Schfo).-Very like the two preceding in shape, but with the cuneus and membrane shorter; black, brown, or pale greyish-brown, never clear orange or yellow, cuners in the pale examples generally darker than the elytra; membrane dusky or nearly black, a streak along the edge of the cuneus hyaline; legs and antennas very pale ochreous.

L. $5 \mathrm{~mm}$.

Commou and generally distributed on Corylus.

\section{PLESIODEMA, Reut.}

Oral, clothed with pale hairs, but without deciduous scalelike pubescence, male more elongate, head short, face nearly vertical, rostrum reaching beyoud the posterior cose, pronotum with the sides and base nearly straight, tibir with pale spines, femora unspotted, posterior tarsi with the third joint subequal to the first and second together. There is only one species of this genus. 
P. pinetellum, Zett.- $\hat{\sigma}$ black-brown, $\&$ head and pronotum brown, elytra paler, both sexes clothed with grey pubescence; antennæ ochreous, second joint in the $\delta$ compressed and thickened, as long as the third and fourth together ; pronotum very transverse; elytra in the o brown, base of the cuneus paler, $f$ with the elytra brownish ochreous, corium at the apex outwardly, and cuneus darker, base of the latter pale, membrane slightly dusky, a line along the margin of the cuneus hyaline; legs dusky ochreous, tibix with pale spines, tarsi brown.

L. $3-3 \frac{1}{2} \mathrm{~mm}$.

On firs; Perth, Reuter; Aviemore, Champion; Forres, Norman.

\section{ATRACTOTOMUS, Ficb.}

May be known from any of the other genera with hooklike nerve to the wing cell, except Psallus, by its pale fragile deciduous pubescence; from Psallus it may bo known by the considerably incrassated, densely pilose second joint of the antennx, which is more thickened in the q than in the $\delta$. We have only two British species of the fourteen recorded by Dr. Puton.

(2) 1. Iarger, more convex, male with the second antennal joint incrassated, fusiform, about as long as the width of the head, female, vertex nearly trice as wide as the eye MALI.

(1) 2. Smaller, less convex, male, second antennal joint less incrassated, parallel-sided, much longer than the width of the head, female, vertex, not nearly twice the width of the eye MAGNICORNIS.

A. mali, MLey.-Blackish-brown, tending to reddish in some examples, slightly shining, clothed with black hairs, and densely with pale whitish deciduous ones; antenne with the third and fourth joints thin and pale, fourth about fourfifths as long as the third, second very much incrassated, fusiform, and densely clothed with black hairs, first subtriangular, vertex much wider than the eye in the $\delta$, nearly twice its width in the ? ; pronotum with the sides rounded, 
base nearly straight; elytra with the suture between the corium and cuneus pale outwardly, membrane dusky, nerves paler, a hyaline line along the margin of the cuneus; tibix paler with strong black spines.

L. $3-4 \mathrm{~mm}$.

On fruit trees, Chobham; Barnet, on Crotegnu, Butler; Bugbrooke, Northants, Alurshall; Caunock Chase, Blatch.

A. magnicornis, Full.-More elongate and much fatter than mali, the of distinguishable at once by its long form, the long parallel-sided second joint of the antenni, in these respects it is more liable to bo coufounded with Psallus olscrirellus, whose antenur, however, are pale; both sexes may be known by the narrow vertex, this in the of is hardly wider than the eye, in the $q$ it is about once and a half as wide; the membrane also is paler.

L. $3 \frac{1}{2} \delta \mathrm{mm} .3 \frac{1}{4}$ ․

Conifer's; commonly where it occurs; Croydon, West Wickham, Bromley, Woking; Sheire, Capiron; Norfolk, Edwords; Hurst Green, Wymondley, Barnet, Micklebam, Shalford, Ewhurst, Somerleyton, Suffolk, Butler; Headley Lane, Bitlups; Glauvilles Wootton, Dale.

\section{PSAILUS, Fieb.}

An exteusive genus, many of whose species are extremely closely allied. It may be known by the wing cell having the hook-like nerve, by the shining upper surface, the slender second antennal joint, and the pale, easily-rubbedoff pubescence; the species are mostly oral, and the $\delta$ is slightly more elongate than the $q$, and its antenwe have the second joint longer and thicker; in some species also the sexes vary notably in colour; the tibix are armed with stroug black spines, rising from black spots. Rostrum reaching to the intermediate coxro or beyond them, apical joint of the tarsi as long as or longer than the first and second together. There are fifty-one species recorded by 
Puton in his catalogue, of which our fauna possesses fourteen.

(4) 1. Second joint of the antenna black or partly black.

(3) Larger; male with third and fourth joints of antenna dark, fourth about lialf as long as the third, female, second joint dark, paler in the middle . . .

(2) 3. Smaller; male, third and fourth joints of antennio pale, fourth tro-thirds as long as the third, female, second joint pale, black at the apex

(1) 4. Second joint of the anteuna pale.

(11) 5. Posterior femora not spotted.

(i) 6. Black-brown in both sexes, cuneus entirely diurk . . . .

(6) 7. Not black-brown in both sexes, cumeus pale at the base.

(9) 8. Smaller, shorter and broader, pubescence tine, golden, aud more regular

(\&) 9. Larger, longer, pubescence coarser, white, and less regular
osterior femora spotted, often very

(j) 10. Posterior femora spotted, often very
dark, bat always with still darker spots.

(2.1) 11. Cuneus not entirely white.

(1:i) 1:. Densely clothed with silvery hairs

(12) 13. Not densely clothed with silvery hairs.

(15) 14. Cuneus red at the apex.

(11) 15. Cuneus white at the aper.

(17) $1 \%$. Femora very pale, thickly freckled with black spots . . .

(11i) 17. Femora towards the apex only, spotted BETULETI.

AMBIGUUS.

UBSCURELLUS.

VARIABILIS.

QUERCÛs.

Rotermund.

ALNICOLA.

Fallixil. with black, apes brown or reddish.

(1:i) 1s. Fourth joint of antenne two-thirds as long as the thrrd . .

(18) 19. Fourth joint of antenne about half as long as the third.

(21) 20. Elytra, especially the clavus, freckled with darker red spots . .

(20) 21. Elytra not freckled wath darker spots.

(23) 20. Larger, fourtl joint of antenua rather shorter in proportion to the third.

(22) 23. Smaller, fourth joint of antenua rather longer in proportion to the third. umminutus.

(11) 24. Cuneus entirely white.

(26) 25. Posterior femora pale. . . SAnguneus.

(25) 26. Posterior femora dark . . SAlicillos.

P. betuleti, Fall. (ambignus, D. \& S.).-Clothed with 
pale deciduous hairs, male brown-black, elongate-oval, $q$ ochreous-red, broader; antennie black with the second joint in the of more than twice as long as the third, third twice as long as the fourth; second in the of more than twice as long as the third, paler in its centre, third not quite twice as long as the fourth; pronotum much raised posteriorly, base and callosities black in the $q$; elytra in o with the region within the nerves of the corium darker, cuneus narrorly pale at the base in both sexes; membrane dusky, palo just below the apex of the cuneus; femora pale at the apex in the $\sigma$, red in the $q$, tibir pale with strong black spines in both sexes, their apices and tarsi dark; orifice of sac white.

L. $5 \frac{1}{2} \mathrm{~min}$.

'Ihe largest of our species; occurs on birch, and is generally distributed and common.

P. ambiguus, Full. (otsermus, D. \& S.).-Smaller than the preceding; male with the third and fourth joints of the antenna pale, fourth two-thirds as long as the third, second joint shorter than in betuleti, about as long as the baso of the pronotum; elytra rather less elongate; $q$ easily known by the pale second joint of the antenna, whose apex is broadly black; also by the rather duller ochreous colour, often inclining to grey, or brown; pronotum unicolorous, brown, blackish or ochreous; cuneus always reddish; both seres with the sac orifice black.

I. 4 . $\mathrm{mm}$.

On apple trees, etc., generally distributed.

P. obscurellus, Fill. (pini, D. s. S.; pityophitus, Flor.). -Simall, oval, blackish-brown, clothed with short black lairs, and fine silvery-gold deciduous pubescence; antenno pale, second joint longer than the third and fourth together, basal joint dark in the $\delta$, vertex in the $\delta^{\pi}$ slightly wider than each eye, in the of nearly twice as wide, the eyes being smaller; membrane slightly dusky, the cells darker, a clear spot below the aper of the cuveus; tibic dark in the $\delta$, paler in the $q$, with strong black spines. 
L. $3_{\frac{1}{2}}^{1} \mathrm{~mm}$.

Common on conifers; could only be confounded with the of of Plesiodeme or Atractotomus magnicomis, from the first the pale deciduous pubescence will distinguish it; from the second the slender, pale, second antennal joint.

P. variabilis, Fall. (var. simillinus, D. \&. S., Saund.; var. Whitei, D. S. S.).--Shining; of brown, of very variable in colour, both sexes clothed with fine dark hairs and pale yellow deciduous pubescence, cuneus pale at the base; antenna pale, its second joint in the of slightly thickened, about twice as long as the third, which again is about twice as long as the fourth; in the of the third joint is about two-thirds as long as the second; the general colour of the $q$ may be of a uniform orange-brown, or orange-red, or the head may be blackish-brown as well as the pronotum in front, the scutellum, and a patch on each elytron; or the head, pronotum, and scutellum may be brown, and the corium brown posteriorly, the cuneus red, pale at the base; the membrane is dusky, with a pale spot below the cuneus; the femora mav be red or brown, the tibize are always whitish, with black spines rising from black spots, coxx and trochanters not palo.

L. $3 \frac{3}{4} \mathrm{~mm}$.

Common and generally distributed, on oak, maple, ash, and other trees. For a long time I have maintained our simillimus as a distinct species, but I believe Dr. Reuter is right in sinking it to the rank of a variety; the true simillimus, Kbm., has not yet been found with us.

$\mathbf{P}$. quercûs, $\pi b m$-Luarger than varicubilis, and longer in the $\delta$, and the deciduous pubescence coarser and white, not golden, second joint of the antenna longer, fourth joint about half as long as the third. General colour less variable and both sexes more alike, brownish-red, pronotum and scutellum sometimes darker; cuneus red, narrowly pale at the base; vertex of the o about once and a lialf, $q$ about twice as wide as each eye; posterior femora longer and 
more slender in the $\pi$, bright red in both sexes, coxw and trochanters pale in the $\delta$, white in the $q$.

L. $\delta 5 \mathrm{~mm}$, क $4 \frac{1}{2} \mathrm{~mm}$.

Oaks, Bromley, not rare, but local ; Darenth, Douglas S. Scott; Hastings; Leicester, Marshall; Sutton Coldfield, Blatch.

P. Rotermundi, Scholtz.-Short, oval, densely clothed with deciduous white hairs, greyish-brown or pale greyishwhite, more or less suffused with greyish-brown + , cuneus bright red margined with white. Head whitish, often with a central black stripe in the $\delta$; vertex more than twice as wide as the eye, antenne with the second joint longer than the third and fourth together; pronotum in the dark, with the anterior margin and sides pale whitish, in the of pale, with a line across the callosities dark; elytra with the clavus and lateral margin pale in the $\delta$, in the o pale whitish, with the spaces between the nerves darker, membrane slightly dusky, nervures white; femora and ertreme base of the tibix reddish, the former spotted at the apex, tibice pale, with strong black spinos, their extreme apex and the tarsi black.

L. $4 \mathrm{~mm}$.

On Populus alba, Reigate, Herue Bay, Woking; Norfolk, Elwards; Bath, Bluthwayt; Leicester, Hainault Forest, Narshall; Boxmoor, Piffard.

P. Fallenii, Reut. (salicis, D. S. S.; roseus, Scund., Synopsis).-Of rather a brick red, clothed with dark hairs, intermixed with pale golden decidnous pubescence; eyes very large in the $\delta$, vertex being scarcely broader than each eye, in the of nearly twice as broad, second joint of the antenne in the $\delta$ very long and thick, much longer than the third and fourth together, in the $q$ about subequal to them, third joint not half so long as the second in the $\delta$, more than half its length in the $f$; pronotum with brown atom-like spots. Elytra parallel-sided in the $\delta$, in both sexes with the disc somewhat darker and with the 
cuneus widely pale at the base, very narrowly at the apex, base of the elytra paler in the $q$, membrane dusky, cells at the base, a spot below the cuneus, and a curved band on the disc hyaline, legs very pale, femora freckled with black, tibix with strong black spines.

L. $\delta 5 \mathrm{~mm}$., $+4 \mathrm{~mm}$.

On sallows, not rare, and generally distributed.

P. alnicola, D.\&.S. $\left(a l_{n}, D . \&\right.$ S. $)$. - Very like the preceding, but rather smaller, and of a brighter red, with the pubescence on the elytra collected into spots, cuneus with a very narrow white line at the base near the side, apex not pale, membrane dusky, base of the cells, a spot below the cuneus and a wide band, interrupted near the side, across the disc hyaline; femora in the of reddish at the apex, tibix with very strong black spines and black spots.

L. $3 \frac{3}{4} \mathrm{~mm}$.

Alders and sallows, Reigate, Esher, Chobham, TVoking; Bath, Blathwayt ; Norfolk, Edwards; Dean Forest, Blutch; Hurst Green, Shalford, Butler; Hornsey, Marshall; Taff's Well South Wales, Billups; Forres, Norman.

P. lepidus, Ficb. (var. minor = roseus, D. S:S; Kirschbuuni, Saund.). - Entirely brown, varying in var. minor to orange-yellow, with the corium and cuneus red, the latter in both varieties narrowly pale at the base; vertex in the $\delta$ rather wider than the eye, in the of about once and threequarters as wide, or in var. minor twice as wide, antenna with the third joint nearly twice as long as the fourth, in var. minor about once and a half as long; membrane dusky, with a pale spot below the cuneus and a more or less distinct curved band on the disc hyaline; femora brown, varying to reddish-yellow, with rather large black spots.

L. $41 \mathrm{rmm}$; var. minor, $4 \mathrm{~mm}$.

Both forms of this species occur together on ash, and are at first sight distinct enough; there are, however, intermediate forms uniting them, which make one believe in 
their specifie identity. Not rare and apparently generally distributed.

P. varians, H. Schf. (distinctus, D. S. S.) - Varying from pale straw colour to orange-red, clothed with brown, and decidnous golden hairs, but never of the deep brickred colour of Fullenii or the brighter red of alnicola, nearly always paler on the head and pronotum, scutellum and base of the elytra; cuneus widely white at the base, narrowly at the apex, membrane dusky, the base of the cells and a spot below the cuneus hyaline, sometimes a lyaline round spot near the outer margin and a vague band on the dise are more or less discernible; femora slightly reddened or darkened at the apex and spotted. Vertex in the male wider than the eye, pronotum withont brown atoms; antennas with the third joint in both sexes quite half as long as the second, apical joint hardly more than half as long as the third; elytra in the $\delta$ only slightly more parallel-sided than in the o.

L. 4-4l $\mathrm{mm}$.

Very common on oaks, and also on other trees.

P. diminutus, $\Pi 6 m$. - In general appearance exactly like varians in miniature, from which it differs structurally in having the apical joint of the antenuse two-thirds as long as the third, and the genital segment of the male beneath not carinated; this latter character is strongly marked, but the females are very difficult to distinguish, except by size.

L. $3{ }_{4}^{1} \mathrm{~mm}$.

Not rare, but probably overlooked; on oaks, Woking, Choblam; Hastings, Barnet, Ewhurst, Butler; Oxsbott, Billups; Norfolk, Echwards; Perth, Reuter; Forres, Normen.

P. albicinctus, $\Pi b m$ - A bout the size of the preceding, but rather shorter and broader, and with the pronotum more convex. It may be known from any of its allies by its rather wider pronotum in front, and by the colour of the 
upper surface, especially of the clavus, which is of a greyish tint, freckled with darker red spots, also by the brown atoms with which the head and pronotum are sprinkled; there is a fine pale central line to the pronotum and scutellum, and the hemelytra are of a deeper red than in diminutus, the posterior femora are more incrassated, and the anterior tibio armed with more numerons and thicker black spines.

L. $3 \frac{1}{4} \mathrm{~mm}$.

One of on Salix, Choblam, July, 1892. Reuter says it occurs also on oaks.

P. sanguineus, Fub. (querceti, D. \&. S.).-Varies in colour from bright red to whitish-grey, with a few small red spots on the elytra, cuneus always white, unspotted; antenne pale, third and fourth joints together about as long as the second in the $\delta$, or longer than it in the $q$; vertex once and a half $\delta$, twice $q$, as wide as the eye; elytra with fine pale hairs somewhat irregularly collected in patches, membrane nearly clear, with a dark transverse line below the cuneus, femora with a few black spots, tibic pale, with strong black spines.

L. $3 \frac{1}{2}-4 \mathrm{~mm}$.

On Sixlix, common and generally distributed.

P. salicellus, Meyer:-Subelongate, greyish, densely clothed with long pale and brown hairs intermixed, elytra densely sprinkled with small brown spots; eyes in the o very large and prominent, each nearly as wide as the vertex between them, in the of smaller, not half the width of the vertex, antennol long and slender, third and fourth joints together considerably longer than the second, fourth twothirds as long as the third; pronotum short, sides nearly straight; elytra elongate and nearly parallel-sided in both sexes, elothed with pale hairs in patches, clavus paler, cuneus white, membrane dusky, the larger cell except at its apex, a spot below the cuneus, and a broad discal band hyaline, very dark between these latter; legs paler, femora 
sprinkled with fine brown spots, posterior femorn elongate, brown, posterior tibiæ very long and slender.

L. $4 \frac{1}{2} \mathrm{~mm}$.

On Corylus and Salix; Reigate, Wimbledon, Woking, Hastings; Headley Lane, Billups; Glanvilles Wootton, Dale; Bickleigh, Devon, Bignfll; Caterham, Tilgate, Darenth, Champion; Wickham, Tunbridge Wells, Douglas \&. Scott; Netherfield, Battle, Frant, Stevenage, Barnet, Shalford, Butler; Lastingham, Birch Wood, Murshall; Norfolk, Edwaris.

\section{PLAGIOGNATHUS, Ficb.}

Under this name I have included as subgenera four genera as defined by Dr. Reuter. But the genus in the wider application that I Lave given to it seems to me to be definite, whereas the characters whereon the subgenera are based are to my mind far from being so; and having in view the small number of our British species, I think it is better to keep them all together. The genus in this sense may be known from the others with the hook-like nerve to the wing-cell, by the combination of the following characters: the shining and finely pubescent surface, without deciduous fragile hairs, the simple antenno, and the blackspined tibia. In form they may be oval or oblong-oval, and in some species of the subgenus Agaliastes both seres are dimorphous. We have nine species in this country, out of thirty-seven recorded by Puton as Palrarctic.

(2) 1. Vertex with a distinctly raised carina, antennæe short, with the second joint longer than the third and fourth together. (Subg. Sthenarus, Fieb.).

ROSERI.

(1) 2. Vertex without a distinetly-raised carina, third and fourth joints of antenna together longer than the second.

(8) 3 Male more parallel-sided and elongate than the female, femora pale, spotted or lined with black, or surface clothed with silvery white hairs. (Subg. Plariognathus, Fieb.)

(5) 4. Surlace clothed with silvery hairs . ALbirexnis. 
(4) 5. Surfoce not clothed with silvery hairs.

(7) 6. Femora margined with black . . ARisustorus.

(i) 7. Femora spotted at the apex, but not margined with black . . viridulus.

(9) 8. Male and female nearly alike in shape, femora dark or red, upper surface not clothed with silvery hairs.

(14) 9. Spines of tibia strong and black. rising from black spots. (Subg. Neocoris, D. \& S.)

(11) 10. Base of corium pale . . . . Bouemannt.

(10) 11. Elytra entirely dark.

(13) 12. Larger, a pale spot near each eye . . NIGRTturds.

(12) 13. Smaller, head entirely black : : PULICARIUS.

(9) 14. Tibie with fine black spines, not rising out of black spots.

(16) 15. Base of the elytra pale . . . SAltrtans.

(15) 16. Base of elytra concolorous with the rest . WILEINsonI.

\section{(SubG. STHENARUS.)}

P. Roseri, H. Schf.-Oval shining, $\delta^{\pi}$ and $q$ alike in form, clothed with very fine decumbent pale hairs, varying from black with the extreme base of the corium laterally and the cuneus testaceous, to entirely testaceous with the head only darker; the femora always more or less red, the tibiæ pale with black spots and spines, tarsi with the apex black; the elytra often are only black on the disc of the corium, pale on the clavus and lateral margin, with the cuneus reddish; antennæ with the second joint longer than the third and fourth together; pronotum transversely rugose, sides slightly rounded; elytra punctured, their sides rounded, membrane smoky, often darker towards the apex.

L. $4 \mathrm{~mm}$.

On Salix, Bromley; Norfolk, Edwards; Battersea, Marshall; Oxshott, Billups.

(Sobg. PlagiogNATHUS.)

P. albipennis, Fall.-Pale greyish white, densely clothed with rather lcng silvery hairs; head darker in front, 
antennx with the first joint dark, second dark at the base, gradually paler to the apex, and slightly thickened apically in the $\delta$, third and fourth joints pale; pronotum very transverse, sides slightly rounded; elytra with the corium inwardly, and generally the cuneus, except at its base, slightly darker, membrane dusky, nervures and a spot below the cuneus white; femora brow ush grey, tibiæ pale, with black spots and spines.

L. $\delta 4 \mathrm{~mm}$. q $3 \mathrm{~mm}$.

On Artemisia absinthium and abrotanum; Reigate, Southwold, Hayling Island, Woking; Norfolk, Edwards; Devon, Parfitt; Lastiughnm, Marshall; Colwyn Bay, Bearmont; Sheppey, Champion; Deal, Billups; Portland, Dale; Eltham, Lee, Bignell.

P. arbustorum, Fub.- oblong oval, $q$ oval, both sexes varying from nearly entircly black to ochreous yellow or greyish green, but through all its varieties known by the black first and second joints of the antenna, and the black margins of the femora; the surface is clothed with black hairs; in the paler varieties the head is always more or less black, and in the darkest the vertex is more or less pale, the membrane is dusky with a clear spot below the cuneus; the femora are ochreous, spotted and margined with black, the tibire ochreous with black spots and spines, their extreme base and apex black, tarsi black.

L. $4-4, \frac{1}{2} \mathrm{~mm}$.

Very abundant on nettles, etc., and generally dis. tributed.

P. viridulus, Fall.-Like the preceding in shape, and clothed with black hairs, but always green or ochreous, or greyish green, sometimes with a brownish tinge, head concolorous; it may always be known by the basal joint of the antennw, which is pale at its extreme aper, with a dark ring below it, and black at its extreme base, the whole joint except the extreme apex is sometimes black in the $\delta$, the second joint is black only at the extreme base, the 
femora are pale, spotted at the apes, but without black orlges.

L. $4-4.1 \mathrm{~mm}$.

Very abundant, often with the preceding.

\section{(Suba. NEOCORIS.)}

P. Bohemanni, Full.-Flatter and broader than the preceding, brown, clothed with very fine adpressed pale hairs, bases of the corium and cuneus, a spot on each side of the vertex and of the scutellum, and sometimes the dorsal line of the pronotum, pale; femora pale at the base and apex, tibire pale with black spots and spines, apex of tarsi black. Head wide, eyes prominent; pronotum not quite twice as broad at the base as long, anterior margin a little more than half as long as the base, callosities strongly marked, sides slightly sinuate, base straight; elytra widest behind the middle, sides rounded; membrane dusky, a clear spot below the apex of the cuneus.

L. $3-3 \frac{1}{4} \mathrm{~mm}$.

On dwarf sallows, Deal; Barry Island, South Wales, Bitlups.

P. nigritulus, Fall. (Scotti, Ficb.).-Entirely brown, except the extreme basal angle of the corium, a spot on each side of the vertex, and sometimes of the scutellum, which are pale, otherwise like Bolemanni. Dr. Reuter finds the pronotum longer in this species, but I fail to appreciate this character; they are found together, and I strongly suspect they are but varieties.

L. $3 \mathrm{~mm}$.

On Sallows, Deal; Marsh Mills, Plymouth, Bignell.

\section{(Sodg. AGalliastes.)}

P. pulicarius, I'all. (var. mullus, Reut.).-Entirely black except the apices or the whole of the femora, the apical joints of the antenna and the tibia. Very like a small nigritulus, but easily distinguished by its wider pronotum in front 
the anterior margin being nearly three-fourths as long as the base; surfuce clothed with fine greyish adpressed hairs; cyes Inrge, not prominent, antenno with the third and fourth joints and often the apex of the second pale; pronotum transverse, sides straght; elytra with the sides slightly rounded, scarcely widened behind the middle; membrane dusky; femora entirely, or with the apex only, more or less pale, tibia with largo black spots and strong black spines.

L. $2 \frac{1}{3} \mathrm{~mm}$.

So far as I can see all our specimens belong to var. mellus, lieut.

Not very common, but generally distributed, at the roots of grass in dry places.

P. saltitans, Fall-Brownish black, elytra brown, paler at the base, cuneus pale at the base. Head conves, antenuse black brown, third joint scarcely more than half as long as the second, second robust, slightly thickened to the apex; base of the pronotum about as wide as the liead in the undeveloped form and not raised, considerably wider than it and much raised in the developed; elytra longer than the abdomen in the developed form, reaching to about the middle of the abdomen in the undeveloped, theix apices rounded, in this form the elytra are generally pale also at the apex; hind femorn very wide, brown, their apices and the tibir paler, the latter with fine black spines, apex of tibia and tarsi lark.

L. $3 \mathrm{~mm}$.(macr.), 2-21 $\mathrm{mm}$. (brach.).

Lowestoft, Coombe Wood, Hampton Wick; St. Leonard's, Slralford, Butler; Norfoll, Edwards; West Kilbridge, Douglas; Chepstow, Billups; Colwyn Bay, Beaumont; Perth, Renter; Freshwater, Isle of Wight, Dale.

P. Wilkinsoni, D. \&. S.-Very like the preceding but entirely brown, without paler markings. Antenne pale, second joint not nearly twice as long as the third and not so thick as in saltitans; tarsi pale; the head also is less 


$$
\text { Capside. }
$$

convex and the posterior femora longer and less incrassated.

L. $3 \mathrm{~mm}$. (macr.), 2-2 $\frac{1}{2} \mathrm{~mm}$. (brach.).

Scarborough, Wilhinson; l'orth, leuter; Strathglass, Braemar, June (1100 ft.), Inverness-shire, Aberdeenshire, and Kirkcudbrightshire, $F . B$. White.

\section{ASCIODEMA, Reut.}

This genus contains two species, both very pale in colour and clothed with rather long pale hairs. The $\delta$ is somewliat more elongate and parallel-sided than the $q$, and has tho second joint of the antenno thickencd; the rostrum extends to beyond the posterior coxa; the pronotum is rather short and trapeziform, the base nearly straight; the elytra are very thin and somerlat translucent; the tibio are armed with fine dark spines not rising from dark spots, third joint of the tarsi shorter than the second; the wing-cell normally has a hook-like nerve, but in some specimens it is without it. Wo have both species in England.

(2) 1. Very pale ochreous, membrane nnspotted . FIEBrr.

(1) 2. Greenish grey, membrane with an angular dark line velow the cuneus . . . . oBsoletrm.

A. Fieberi, D. $\oint$. S. (Psallus).-Shining, oblong oval, entirely pale ochreous, clothed with concolorous hairs. Eyes black, vertex once and a half as wide as the eye in the $\sigma^{\circ}$, three times as wide in the $q$, second joint of the antenno as long as the third and fourth together; pronotum about twice as broad behind as in front, impressed behind the callosities; elytra with the sides slightly rounded; posterior femora slightly incrassated.

L. $4 \frac{1}{2} \mathrm{~mm}$.

On Wych Elm, Bovingdon, Herts, Pifiard; Croydon and Shirley, June and July, on palings, Douglas and Scott; Reigate.

A. obsoletum, D. $\oint^{\circ} S$. (Tinicephalus), (Ovthotylus Y 2 
Saundersi, Reut.).-Like an Orthotylus in form and general appearance, greyish or greyish green, clothed with fine white hairs intermixed with darker ones, male subelongate parallel-sided, of suboval, verter in the of only slightly wider than each eye, in tho o nearly three times as wide. Head and pronotum generally greener than the elytra; second joint of the antenna not so long as the third and fourth togetler; pronotum in the of not twice as broad at the base as in front; elytra greyish, often more or less brown between the nerves, membrane with a peculiar narrow dusky nugulary-shaped mark, which origiuates near the lateral margin below the cuneus, crosses the membrane for about a third of its width, then turns at right angles and runs towards the apex which it does not quite reach; tibia with fine black spines.

L. $4 .-5 \mathrm{~mm}$.

Common on Furze and Broom, and generally distributed.

\section{CRYPTOCERATA.}

\section{NAUCORID}

We have two genera in this family, which may be known by the following characters:-Broad-oval; head deeply sunk in tho anterior margin of the pronotum, face horizontal or slightly declivous, antennæ four-jointed, hidden below the eyes; scutellum triangular, large; elytra, when developed, with the clavus well marked, membrano sometimes distinct, but in our British Naucoris not distinguishable from the corium; anterior femora more or less dilated and flattened, often greatly so, tarsi distinct (Aphelochimus or apparently in one piece with the tibice (Naucoris), intermediate and posterior tarsi two-jointed and with two distinct claws.

(2) 1. Front tarsi without claws . . . Navconis.

(1) 2. Frout tarsi with two distinct clars: ApLELocurnus. 
NAUCORIS, Geoffr.

Broad oblong oval, head and eyes buried in the pronotum so that the sides of the pronotum, eyes and front of the head form a continuons curve. Head very wide, trvice as wide as long; rostrum short, three-jointed, almost triangular; pronotum with the base only slightly wider than the anterior margin; elytra nearly covering the apex of the abdomen in our species; connexivum clothed at the sides with long hairs, with the posterior angles of the segments produced; anterior femora very much dilated, tibiæ curved, the single-jointed, simple, clawless tarsi appearing as a continuation of the tibia, tarsi of second and third pairs of legs two-jointed, the posterior ones clothed with long natatorial lairs. There are three Palwarctic species, of which we have only one.

N. cimicoides, Linn.-Shining, slightly convex, ochreous; head and pronotum highly polished, the former with an impressed row of punctures near each oye, and a darker brown mark down the centre; the latter with a row of punctures parallel to the base, and a fow other scattered ones at the sides and on the disc, a subquadrato spot on each side of the disc irrorated with brown; scutellum brown, paler at the basal angles; clytra dull, exceedingly closely and finely punctured, greyish brown; connexivum ochreous, apices of the segments darker; legrs ochreous.

L. $12-16 \mathrm{~mm}$.

In ponds not rare, and apparently widely distributed.

\section{APHELOCHIRUS, Westw.}

This very distinct genus, of only ono species, may bo known at once by its very depressed and short oval form, its narrow head, and parallel-sided sublongitudinal eyes, its long narrow rostrum, the form of its pronotum, whose 
hase is much more than twice as long as the distance between its anterior angles, and the distinct two-jointed and two-clawed anterior tarsi. The elytra are generally undeveloped and appear only as two transverse scales about twice as long as the scutellum, when developed they have a distinct membrane; $\delta$ with the last abdominal segment produced and almost coveriug the genital segments, the division between this and the preceding hardly perceptible, the two segments being apparently amalgamated, in the of all the abdominal segments distinct, the last largely emarginate, exposing the genital segment, connexivum in both sexes spinosely produced at tho posterior angles; all the tarsi two-jointed, not hairy and with two claws.

A. restivalis, Fab.-Head, legs and rostrum and sometines the margins of the pronotum, and abdominal segrments testreeous yellow, rest dull dark greyish brown. Head distinctly punctured; pronotum with the anterior margin very deeply excavated, receiving the head almost to the front of the eyes, sides rounded, base straight, its surface and that of the scutellum and elytra very fivmly rugose; anterior femor very wido towards the base gradually narrowing to the apex.

L. $10 \mathrm{~mm}$.

Near Bagley Wood, Oxford, Ilope; in the Evenlode at Eynsham Paper Mills, Westwood; Avon, near Bath, late Mr. C. Broome; Castessy, near Norwich, J. L. Brown; Worcester, Dale.

\section{NEPID压。}

This family may be known at once by the long and filamentary breathing tubes; there are only two British genera, which differ entirely in form and general facies. The family characters which they have in common, besides 
the anal tubes, are the short triangular three-jointed rostrum, three-jointed antenne, the second joint of which is produced into a lateral process, and the single-jointed, clawless, curved, anterior tarsi ; intermediate and posterior legs ambulatory, with one-jointed tarsi terminating in two nearly parallel claws.

\section{NEPA, timn.}

Flat, broad, widest behind the centre of the elytra. Head small, not half so wide as the pronotum in front, sunk up to the eyes in a decp emargination of the anterior margin; pronotum with the sides nearly straight; scutellum large, pointed; elytra with a membrane which however has no distinct suture; anal tubes about as long as the elytra; anterior coxæe short and very thick, femora thickened, tibiæ, when folded back, fitting into a groove in their anterior margin. 'There are only two Palaarctic species, of which we have one. Dr. l'uton mentions that the eggs are provided with seven filaments which in the ovary embrace the preceding egrg.

N. cinerea, Linn.-Dull ochreous brown, femora with darker mottling; surface of pronotum somewhat rugose, of the elytra subreticulate; abdomen above, red at the sides; other characters as given under the generic heading.

L. 18-20 mm. ; fil. about $11 \mathrm{~mm}$.

Common in mud at the bottom of ponds, etc., and generally distributed.

\section{RANATRA, Fab.}

Very elongate, subcylindrical. Head wider than the pronotum in front, eyes very prominent; pronotum more than twice as long as wide, base deeply and angularly emarginate; scutellum diamond-shaped; elytra not quite so long as the abdomen, membrane distinct and divided by a suture from the corium; filaments very long, longer 
than the abdomen; legs very long, anterior cosx elongate and linear, two-thirds as long as the femora, which are slightly curved upwards towards the apex, bearing a sharp tooth on the lower margin just at the commencement of the curve, between which and the apex they are grooved to receive the tibia and tarsus in repose, each side of the groove being finely serrate, tibia and tarsus, when folded back, reaching to just beyond the spine, the tibia curved, terminating just at the spine, the tarsus very short and clawless. TVe have one of the two recorded Palaarctic species. Dr. Puton says that the eggs havo two filaments in this genus.

R. linearis, Iinn.-Ochreous; pronotum constricted towards the middle, with the anterior margin angularly emarginate, sides sinuate, base twice as wide as tho anterior margin; abdomen above red.

L. $32-35 \mathrm{~mm}$; fil. about $28 \mathrm{~mm}$.

Rarer than Nepa, in ponds, on the bottom; Wandsworth Common, Hammersmith Marshes, Dunglas ame Scott; Earlswood, J. Limell; Chobham, Evesham, Knowle, Blatch; Norfolk, Eilwails; Lee, Esher; St. Leouards, Guestling, Mill Hill, Middlesex, Butler; Holywell, Cardiff, Billups; Hayling Islaud, Wimborne, Cambridge, Dule.

\section{NOTONECTID $F$.}

Convex, elytra tectiform; head wider than tho pronotum, eyes lirge, rouuded, face convex vertical, antenux four-jointed, rostrum short, stont at tho base, conical, three- to four-jointed; scutellum large; elytra as long as the abdomen; anterior legs with the femora slightly thickened at the base, tarsi two-jointed, quite distinct from the tibire and articulated at their juncture, posterior legs with the tibio and tarsi, more especially tho latter, ciliated in Notonecta, simple in Plea. 
NOTONECTA, Lim.

Head broad, eyes large, vertex not half so wide as either eye, rostrum four-jointed; pronotum trapeziform, transverse, very convex, anterior margin slightly produced in the centre, sides straight, base slightly produced and rounded near the angles; scutellum almost as wide as the pronotum, and nearly equilateral; elytra more than twice as long as wide, pointed, membrane distinct; abdomen ciliated at the sides and apex, carinated and ciliated along the centre beneath; sterna with golden hairs; all the tarsi two-jointed, posterior pair with long cilix, intermediate femora with a sharp tooth near tho apex. There are two European species, of which only one has occurred in this country; the insects swim on their backs, and they aro capable of biting with some severity.

N. glauca, Linn. (var. maculata, Fab.).-Head and pronotum shining, ochreous white, or ochreous, the latter generally with a dark band across the base; scutellum dull, black; elytra ochreous, with a row of black spots along the lateral margins, or (var. furcata) bluish black, with two elongate spots at the base, or (var. maculata) reddish ochreous, irrorated with black or brown spots; legs palo ochreous, or greenish; abdomen black.

L. $15 \mathrm{~mm}$.

Common and generally distributed, the ordinary "water boatman" of our ponds; var. maculate rarer.

PLEA, Leach.

Minute, not twice as long as wide. Head broad, eyes remote, vertex twice as wide as either cye, rostrum threejointed; pronotum rounded in front, sides very short, base largely produced and rounded; scutellum narror, triangular; elytra short, very declivous posteriorly, without distinct membrane, a small portion of each elytron is separated off. by a suture close to the exterior basal angle (this 
is considered by Messrs. Douglas and Scott to represent the embolium); legs simple, tarsi two-jointed, posterior pair longer than the others, but not natatorial as in Notonecta.

P. minutissima, Fal.-Ochreous, very strongly punctured; head with a dark central line, elytra sometimes with a transverse band across the centre, and the apex darker.

L. $2 \frac{1}{2} \mathrm{~mm}$.

Generally distributed.

\section{CORIXID死。}

Subelongate or elongate oval, somerhat flat. Head viewed from above, very transverse, wider than the pronotum, very concave posteriorly, so as to cover and embrace the front of the pronotum, eyes large, triangular, with few exceptions, their posterior margins straight, nearly parallel to and touching the posterior margin of the lead, looked at from above, their anterior margins form a continuous curve with the front of the head, face elongate, rounded and vertical in front, then produced triangularly with a subventral aspect, antemue three- to four-jointed, no distinct rostrum, but the underside of the head, in front of the occipital foramen, is divided by a transverse suture from the apical portion, which is rounded in front, and from its margin projects a series of long jellow hairs; pronotum more or less triangular, the sides being exceedingly short, and the base generally produced and angulated; scutellum present, or wanting; elytra with a more or less distinct membrane, and a deep sulcus along the lateral margin; anterior tibia very short, tarsi or palo variable in form, one-jointed, intermediate legs elongate, tarsi one-jointed, terminating in two long narrow claws, posterior tarsi flattened and oar-shaped, two-jointed, their sides clothed with long hairs; pleurx of the sterna distinct, mesosternum with a lateral piece beyond the pleura 
in Corixa, called by Sahlberg the parapleura. Segments of abdomen asymmetrical in the $\delta$, symmetrical in the o; male with a "strigil" on the upper side of the sixth segment (see Introd. p. 10) in most of the species. There are two genera in the family, easily distinguished by the presence or absence of the scutellum.

(2) 1. Larger: scutellum wanting . . . CorIxa.

(1) 2. Very small: scutellam present . Srgara.

\section{CORIXA, Geoffr.}

To the above characters of the family need only be added, that the scutellum in this genus is wanting, that the base of the pronotum is angulated in the centre (except in coleoptrata), and that the antenne are four-jointed, the fourth joint thin, filiform, the third longer than the first and second, and somewhat swollen. $W_{\theta}$ have twenty species of this genus, of the fifty-five recorded as Palæarctic by Dr. Puton; they have been divided into four subgenera, as shown in the table of species.

(46) 1. Pronotum with pale transverse lines.

(5) 2. Large species, pronotum and elytra not rastrate, asymmetry to left in the male. (Subg. Macrocorisa, Thoms.)

(4) 3. Larger, pronotum with sixteen or more pale lines . . Geofrroy.

(3) 4. Smaller, pronotum with 12-14 lines: ATOxarIA.

(2) 5. Smaller species, pronotum and elytra more or less rastrate, asymmetry to right in the male.

(43) 6. Pronotal dorsal carina when present only visible near the anterior margin.

(34) 7. Basal joint of posterior tarsi pale at the apex. Male with a strigil. (Subg. Corixa, Geoff.)

(11) 8. Corium not rastrate,

(10) 9. Pronotum dark with pale lines, the dark lines as broad as the pale. IUGUBRIS.

(9) 10. Pronotum pale with narrower dark lines. HIEROGLYPHics.

(8) 11. Corium rastrate.

(21) 12. Larger species, $7-8 \mathrm{~mm}$.

(16) 13. Clavus and corium very rastrate, dull, transverse pale lines very narrow, nearly entire. 
(15) 14. Pronotum with six pale lines, apex of corium not pale.

(1) 15. Pronotum with $7-8$ pale lines, apex of corium widely pale bi so deeply

(1:i) 16. Clavus and corium not so deeply rastrate, less doll, transverse pale lines wider, much abbreviated and interrupted.

(1ii) 17. Pronotum with six rale lines, pale lines of clavus much dilated inwardly STRIATA.

(17) 18. Pronotum with 8-9 pale lines.

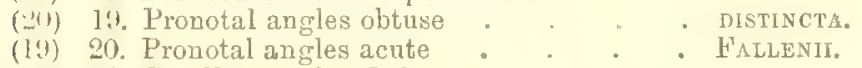

(12) 21. Smaller species, 5-6 mm.

(ei) $2:$ Intermediate tibia scarcely longer than the tarsi, tarsi subequal in length to the claws

(2.2) 23. Intermediate tibix much longer than tarsi, tarsi much shorter than claws.

(ii) 2.t. Pronotum much longer than the vertex of the head, crossed lyy 7-10 pale lines.

(30) 95. Male with the facial impression large, continued upwards between the eyes, transverse marlings of the corium divided into series by longitudinal dark lines.

(27) 20. Male facial impression very deep and strongly margined, terminated superiorly in a deep rounded arch, female with two black longitudinal lines on the corium :

(20) 27. Male facial impression subtruncate
superiorly, female with three or four superiorly, female with three or four

(29) 28. Male facial impression very deep, and concave. Anterior tibia much swollen, female more elongate, its palo short, not twice so long as wide. . .

(28) 29. Male facial impression not very deep, anterior tibio scarcely swollen, femalo broader, its pala more than twice as long as wide

(25) 30. Male facial impression very shallow, not reaching upwards between the eyes, markings of the corium not divided into series by longitudinal dark lines.

(2.1) 31. Pronotnm shorter than or as long as the verter of the head, crossed by 5-6 pale lines.

(iii) 32. Larger, pronotum with six pale lines, facial impression of male distinct, abruptly terminated above. .

LINNTII.

S.MHLEETi.

MUETA.

LIMITATA.

Semistriata.

VENUSTA.

FabriciI.

(:i2) 33. Smaller, pronotum with five pale lines, 
male withont a distinct facial im. pressiou . . . .

(7) 34. Basal joint of posterior tarsi black at Scotti. the apex, male without a strigil. (Subg. Callicorixa, B. White.)

(36) 35. Claval markings longitudinal.

Boldi.

(35) 36. Claval markings transverse.

(42) 37. Pronotal angles obtuse, markings of corium transverse.

(41) 38. Pronotum with 8-9 pale lines.

(40) 39. Claws of intermediate legs as long as the tarsi . . .

(39) 40. Clarvs of intermediate legs not nearly so long «s the tarsi.

(38) 41. Pronotum with seven pale lines .

(37) 42. Pronotal angles acute, markings of corium guttulate or vermiculate.

(6) 43. Pronotum with a distinct central keel. (Subg. Glænocorisa, Thoms.) . CARINaTA.

(44) 45. Intermediate tarsi as long as the tibio.

(Subg. Orcinocarixa, B. White.)
(1) 46. Pronotum witlont transverse markings. (Subg. Cymatia, Flor.)

(48) 47. Pronotum nearly as long as the head - BonsDorfrir,

(47) 48. Pronotum about one-third as long as the head

\section{(Suba. MACROCORIXA, Thoms.)}

C. Geoffroyi, Leach.-Greenish black, entirely smooth and shining; pronotum with sixteen to twenty irregular pale transverse lines; elytra, including the clavus and membrane, closely mottled with short vermiculate pale markings, irregularly punctured; legs testaceous, front tibiro of the $\delta$ with a spine at the apex, palæo elongate, parallel-sided, rounded on the upper margin close to the blunt apex, lower margin straight, of the of elongate, curved, pointed; intermediate tibix simple, tarsi shorter than the tibio, claws hardly shorter than the tarsi.

L. 13-14 mm.

Common and generally distributed.

C. atomaria, Illig. (Panzeri, Fieb.; affinis, Leach).Very like the above but smaller, with the pronotum 
shorter and consequently with only about fourteen pale lines; the pala of the front legs in the malo shorter, more rounded on their upper margin, and consequently less parallel-sided, those of the female shorter and more curved.

L. 9-10 $\mathrm{mm}$.

Not so common as the preceding, but generally distributed, although not recorded from Iroland.

\section{(Subg. CORIXA, Gcotir.)}

C. Iugubris, Fieb. (Stâti, Fieb.).-Black brown, shining, frontal impression of male short, not extending upwards between the eyes; pronotum and clavus very superficially rastrate (i.e. striated like a file), corium punctured; pronotum with seven pale transverse lines, its angles obtuse; elytra with the markings at the base of the clavus broader and in more regular lines, towards the apex narrower and fragmentary, markings of corium transverse, short and somewhat arranged in longitudinal series, a line at the inner angle of the corium, and a longitudinal line parallel to it, black; pale of front legs in the male very wide at the base, pointed at the apex, apex of intermediate tarsi black.

L. $6-6 \pm m m$.

Common and generally distributed, often in brackish water.

C. hieroglyphica, Duf.-Frontal impression of the $\delta$ very deep, extending upwards between the eyes in a welldefined arch; pale greenish or yellowish white; pronotum with 7-8 narrow black transverse lines, finely rastrate; clavus rastrate, pale at the extreme base, otherwise traversed by short irregular black lines, corium not rastrate, punctured, with short, transverse fragmentary dark markings arranged in three or four series; legs entirely pale, pala of $\delta$ straight on the anterior edge, regularly curved on the posterior.

L. $5 \frac{1}{2}-6 \frac{1}{2} \mathrm{~mm}$. 
Common, often with the preceding, generally distributed.

C. Linnæi, Fieb-Dark brown-black; frontal impression of ot scarcely indicated; entire surface of pronotum and elytra, except the membrane, very rastrate; pronotum with 5-6 lines, and the margins pale; elytra with the markings of the clavus and corium very narrow, wavy and almost entire, continued to the apex; legs pale, palw of 8 concave in front, widened and blunt at the apex.

L. 7-8 mis.

Common and generally distributed.

C. Sahlbergi, Fieb.-Very like Linnai; frontal impression of the male distinctly marked and abruptly terminated on its superior margin; pronotum more elongate with from 7-9 transverse pale lines; apex of the corium pale, the transverse lines there becoming obliterated; anterior palæ of the $\delta$ much as in Linnæi, intermediate claws shorter than the tarsi.

L. 7-8 $\mathrm{mm}$.

Common and generally distributed.

C. striata, Fieb.-Rather an elongate species, easily known by the six pale lines of the pronotum, whose angles are obtuse, by the basal pale lines of the clavus being much dilated inwardly, and by the discal markings of the corium being separated by a broad dark line, both from the claval and lateral margin; intermediate claws shorter than the tarsi; facial impression of the of very slight, abruptly and truncately terminated superiorly; palie shortly cultrate.

L. $6 \frac{1}{2}-7 \mathrm{~mm}$.

Very common and generally distributed.

C. distincta, Fieb. (Dorglasi, Fieb.).-Easily known from the above by the 7-8 pale lines of tho pronotum, the narrower, scarcely, if at all, dilated lines of the clavus, the longer intermediate claws, which are as long as or longer than the tarsi, and the finer transverse lines of the corium, which has usually a dark line torvards the apex of the 
claval suture only; frontal impression of male shallow, somewhat cordate, not extending betwoen the eyes; palis broadly cultrate.

L. 7-7! $\mathrm{mm}$.

Not rare, Reigate, Chobham; Norfolk, Elwards ; Bridgenorth, Devon, Murshall; Newcastle, Ireland, Champion; Forres, Norman; Perth and Shetland, Reuter; Strathglass and Achilty, B. White; Glanvilles Wootton, Weybridge, Dale; Plymbridge, Yelverton, Bignell.

C. Fallenii, Fieb-Very like clistincte, but at onco known by the acute lateral angles of the pronotum; it is generally but not always palcr in colour; the palre of the male are truncate at the base, their upper margius rounded; facial impression shallow, truncate above, not extending upwards between the oyes.

L. $7-7 \frac{1}{2} \mathrm{~mm}$.

Common and generally distributed.

C. mcesta, Fieb.-Small, rather short, easily known by its obscure, indistinct markings, which gradually fade off towards the apex of the corium, and by the form of the intermediate legs, the tarsi of which are almost as long as the tibia, and the claws not or scarcely longer than the tarsi; pronotum with about seven pale lines; facial depression of the of small, shallow, rounded above, not produced between the eyes; palie subparallel-sided, blunt at the apex.

L. $5 \mathrm{~mm}$.

Common and generally distributed.

C. limitata, Fieb.-Longer and narrorver than the preceding, markings very clear and distinct; pronotum with 7-8 pale lines, broader than the dark ones; markings of the corium divided into three series by two dark longitudinal lines, one near the lateral margin, the other near the claval suture; male with the frontal impression very deeply excavated, extending high up between the eyes, and terminating above in a deeply rounded arch; 
anterior tibia much swollen, palie narrow at the base, their greatest width about a third from the apex, intermediate claws longer than the tarsi.

L. $6 \mathrm{~mm}$.

Reignte; Lee, Douglas and Scott; Lymington, Barmouth, Blutch; Norfolk, Edwards; Parkhurst Forest, Power; 'Taff's Well, S. Wales, Billups; 'Tilgate, Champion.

C. semistriata, Fieb.-Darker and rather shorter than limitata, very rastrate; pronotum with 7-8 pale lines; markings of the corium divided into four series by three longitudinal dark lines; facial iropression of the male deeply excavated and extended high up between the eyes, not deeply arched above, but terminating in a subtruncato curve; front tibia swollen; palæ short, their greatest width near the base.

L. $6 \mathrm{~mm}$.

Lee, Oambridge Fens, Douglas and Scott; Norfolk, Elwards; Isle of Man, Blatch; Devon, Purfitt; Forres, Norman; Perth, Reuter; Moreton, Cheshiro Coast, Ellis; Armagh, Johnson.

C. venusta, $D . \&$ S. Fxceedingly like semistriata, but rather shorter and wider, the anterior tibin of the $\delta$ not swollen, and the facial impression less deep, and more parallel-sided; in the female the palre are longer and narrower, twice, or more than twice as long as wide; the entire surface is very rastrate, and the pronotum is slightly shorter than in semistriata and has seven pale lines.

L. $5 \frac{1}{2}-6 \mathrm{~mm}$.

Chobham; Carlisle, Hunter; Forres, Norman; Rothesay, Douglas; Orkneys, Reuter; Newcastle, Ireland, Champion.

C. Fabricii, Fieb. (nigrolineata, Fieb.; micans, D. \& S.; dutia, D. \&. S.; borealis, D. \& S.; perplexa, D. \& S.; Whitei, $D . \& . S_{.}$; decora, $D . \& S_{0}$ ). - This species, which is very variable in colour and markings, may be known from the three preceding by the markings of the corium not being divided into series by longitudinal lines, by the more strongly 
marked pronotal tubercle, and the rounded lateral angles; the male may be further known by the narrow and shallow frontal impression, which is not produced between the eyes, but terminated above by a transverse carina; palo widely cultrate, broadest near the middle; pronotum with about oight pale lines.

L. $5 \frac{1}{2}-6 \mathrm{~mm}$.

Common and generally distributed.

C. fossarum, Leach.-Narrower than Iratricii; pronotum with six clear pale lines, its lateral angles obtuse; markings of the corium divided by two dark longitudinal lines, those of the clavus dilated inwardly; male with the facial impression shallow, not carinated but rounded superiorly; palo truncate at the base, subtriangular; vertex. of the head often considerably produced and pointed in the centre.

I. $6 \mathrm{~mm}$.

Generally distributed.

C. Scotti, Fiel.-Very like fossarum, but smaller, with a shorter pronotum, which has only five palo lines, althongh sometimes there is also a pale transporse spot in the basal angle; vertex of the head much produced and pointed posteriorly; facial depression in the male scarcely marked except by a sort of horseshoe-shaped punctured fovea; palie shortly cultrate, widest at the base, which, however, is not so truncate as in fossurum.

L. $5 \mathrm{~mm}$.

Morayshire, Norman; Shetlands, Reuter; Loch near Kinn, Argyleshire, Douglas and Ścott; Islo of Mull, Dale; Strathglass, B. White.

C. prominula, Thoms.? - Under this namo Mr. Douglas has described (Ent. Mo. Mag, xii, p. 224) a species which is closely allied to Scotti, but larger and more obscure. I have, however, only seen a few specimens, kindly lent to me by Mr. Douglas, in the males of which the form of the palre and that of the facial impression are 
intermediate between fossarum and Scotti. Under these circumstances I feel that I must leave it as a doubtful species till more specimens turn up.

L. $5 \frac{1}{2} \mathrm{~mm}$.

Isle of Harris, Jemer Trust.

\section{(SuBg. CALLICORIXA, B. White.)}

C. præusta, Fieb. (socia, D.\&. S.; Wullastoni, D. \&. S.). -In form, colour and markings resembling distincta, but known at once by the large black spot at the apex of the first joint of the posterior tarsi (this is best seen from beneath); in the $\delta$ the anterior palie are elongate, suddenly dilated at about half their length from the base, the dilated portion concave, and bent forwards, apex subtruncate; a spot on the tibia, and another on the dilatation of the tarsus, usually black; pronotum with about nine to ten irregular pale lines, its angles obtuse; markings of the corium narrow, not very much broken; intermediate claws slightly shorter than the tarsi. In var. Wollastoni the markings are very obscure and ill-defined.

\section{L. $7 \mathrm{~mm}$.}

Not rare and generally distributed.

C. sodalis, D. \&. S.-This species, of which I have only seen a malo and female kindly lent to me by Mr. Douglas, appears only to differ from preusta in the shorter claws of the intermediate tarsi, which in both specimens are only about two-thirds as long as the tarsus. The spot on the hind tarsus is only over the inner apical angle.

L. $6 \frac{1}{2} \mathrm{~mm}$.

Gosforth, Bold.

C. Boldi, D. \& S.-I havo not seen the unique $f$ example of this species, which is distinguished by the central markings of the clavus being longitudinal; the spot on the hind tarsus nearly resembles that of masta. Only one example being known, one cannot aroid a z 2 
suspicion that the peculiar markings of the clavas are accidental.

L. 6 ? $\mathrm{mm}$.

Gosforth, Bold.

C. cognata, D. \& S-Another closely allied species, but recognizable by its yellow colour, the seven clear wirle prouotal lines, and the broader, clearer and moro fragmentary markings of the elytra; $\sigma^{2}$ with the pala less suddenly dilated at the aper; anterior tibio not narked with black ; posterior tarsi with rather a large triangular spot.

L. $6 \frac{1}{2} \mathrm{~mm}$.

Strathglass, B. White; Loch Grienan, Rothesay, Douglas; Loch Leven, Power; Shetlands, lieuter.

C. concinna, $D . \rho \cdot S .-A$ very distinct species, known at once by the smooth corium, rastrate only near tho base, the subacute lateral angles of the pronotum, and the guttulate or vermiculate, not transverse, markings of the corium; the promotum has about nino irregular pale lines; the palo of the $\delta$ are simple and cultrate.

L. $7 \mathrm{~mm}$.

Lee, Donglus; Grrvesond, Champion; Hunstanton, Fonler; Esher; Norfolk, Lilwarls; Weymouth, Dale; Moreton, Cheshiro Coast, Ellis; Lincolnshire, J. E. Mason.

(SUBG. GLLNOCORISA, Thoms.)

C. carinata, Sallb. (intricata, D. \&. S.; Sharpi, D. \&. S.). -About the size and shape of Fullenii; pronotum with nino to twelvo palo lines, pronotal angles obtuse, disc of pronotum with an elongate median carina often traceable down to the base; warkings of the clavus and corium very fragmentary and somewhat vermiculate, often very obscure and scarcely traceable, corium shining, rastrate only at the base, clothed with long remote hairs; facial impression of the male large, cxtendiug upwards between the oyes; pala cultrate with a strong lateral curve or bend. 
L. 8-9 min.

Strathglass aud Bracmer, $3000 \mathrm{ft} .$, B. White; Pitlochry, Nomman; Fifeshire, Poucr; Forres, Nomman; Shetlands, Tienter"; Killin, Isle of Harris, Wale; Ireland, Haliday Coll.; Esher, and Newcastle Ireland, Champion.

\section{(SUBG. OREINOCORIXA, B. IThite.)}

C. cavifrons, Thoms. (alpestris, D. \&. S.).-Nearly black; eyes very large and ronuled, projecting fan beyoud the sides of the pronotum, sides of the head behind them produced on each side into a fine spine-like process, face clotbed with yellowish hairs, impression concave in the $\delta$, merely flattened in the $q$; pronotum very rastrate, narrow, and short, its angles subacute, with about seveu paler lines, and a distinct central smooth carina; markings of the elytra very obscure and fragmentary, corium scarcely rastrate; palis of the $\delta$ subtriangular, with a marginated concave eulargement on the upper margin, anterior femora produced, flattened and roundly dilated beneath, especially in the $\delta$, intermediate tibia and tarsi subequal in length.

L. $8-9 \mathrm{~mm}$.

Ben Che aran, Strathglass, $F$. B. White.

(SuBG. CYMATIA, Flor.)

C. Bonsdorffi, Suhlb.-Brown, not rastrate, elytra with fragmentary pale trausperse markings. Head much wider than the pronotum, vertex producedin front between the cyes, longer than the pronotum, eyes remote from the posterior margin which is raised, face excavated $\delta$, or impressed o, clothed with white hairs; pronotum without transverse lines, angles obtuse, side and basal margius slightly raised; dise with a well-marked tuberclo in front; elytra with tho membrane distinct; anterior pala elongate, nearly straight, 
with very long cilin, intermediate tarsi slightly shorter than the tibirs.

L. $6 \mathrm{~mm}$.

Woking, Champion; Norfolk, Litwards; Forres, Norman; Isle of Harris, Dule; Strathglass, $b . B$. White.

C. colcoptrata, Fab.-Much smaller than the proceding, but like it in general characters; elytra without transverse markings. Head very large, three times as long as the pronotum, which is many times wider than long; disc of the latter with a small anterior tubercle; elytra with the lateral sulcus very wide, corium with two dark longitudinal stripes, membrane not distinct.

L. $3 \mathrm{~mm}$.

Whitstable, Champion; Old Trent, Burton-on-Trent, Repton, Fouler; Winchelsea, Isle of Wight, Blutch; Lincolnshire, J.E. Mason; "abundant at Folkestone," $C . G$. IIall; Slapton Lea, Matlock, Horuing; Cambridge Fens, Douglas and scott.

\section{SIGARA, Fab.}

Like a small short Corixa, but antennre three-jointed, face not excuvated in either sex, and scutellum present, mesosteruum without parapleurx.

(2) 1. Pronotum nearly as long as the vertex of the

hear . * . MINTIIssIma,

(1) 2. Pronotnm much shorter than the vertex . . Schoutzi.

S. minutissima, Limn.-Ilead pale, with a slightly darker dorsal line down the vertex, which is rounded in frout, and shorter than its width between the eyes; pronotum dull, greyish brown, its margins paler, about as long as the vertex, base rounded; elytra dull, palo greyish testaceous, with the base of the clavas, corium, and a baud across the latter, beyond the midule, and the membrano darker; legs pale whitish.

L. $2 \mathrm{~mm}$.

Chobham, Cambridge, Billups; Burton, Fouler"; Norfolk, 
Erlwards; Devon, Parfitt; Pett Ditches, near Hastings, Collett; Knowle, Bewdley, Ludlow, Dorchester, Blatch; Ireland, Haliday Coll.; Scarborough, Lawson; Loch Achilty, streams at Braemar, Tay near Perth, F. B. White.

S. Scholtzii, Fieb.-Differs from the above by the longer vertex, which is longer than its width between the eyes, and more angulated in front, and nearly twice as long as the very short pronotum, it is also a paler and much more shining insect, and the spots of the elytra are smaller and more numerous.

L. $2-2 \frac{1}{4} \mathrm{~mm}$.

Chobham; Guestling, near Hastings, Butler; Lincoln, Fowler; Norfolk, Eltwards; Littlehampton and Westonsuper-Mare, Billups. 


$$
\text { - }
$$




\section{N D E X.}

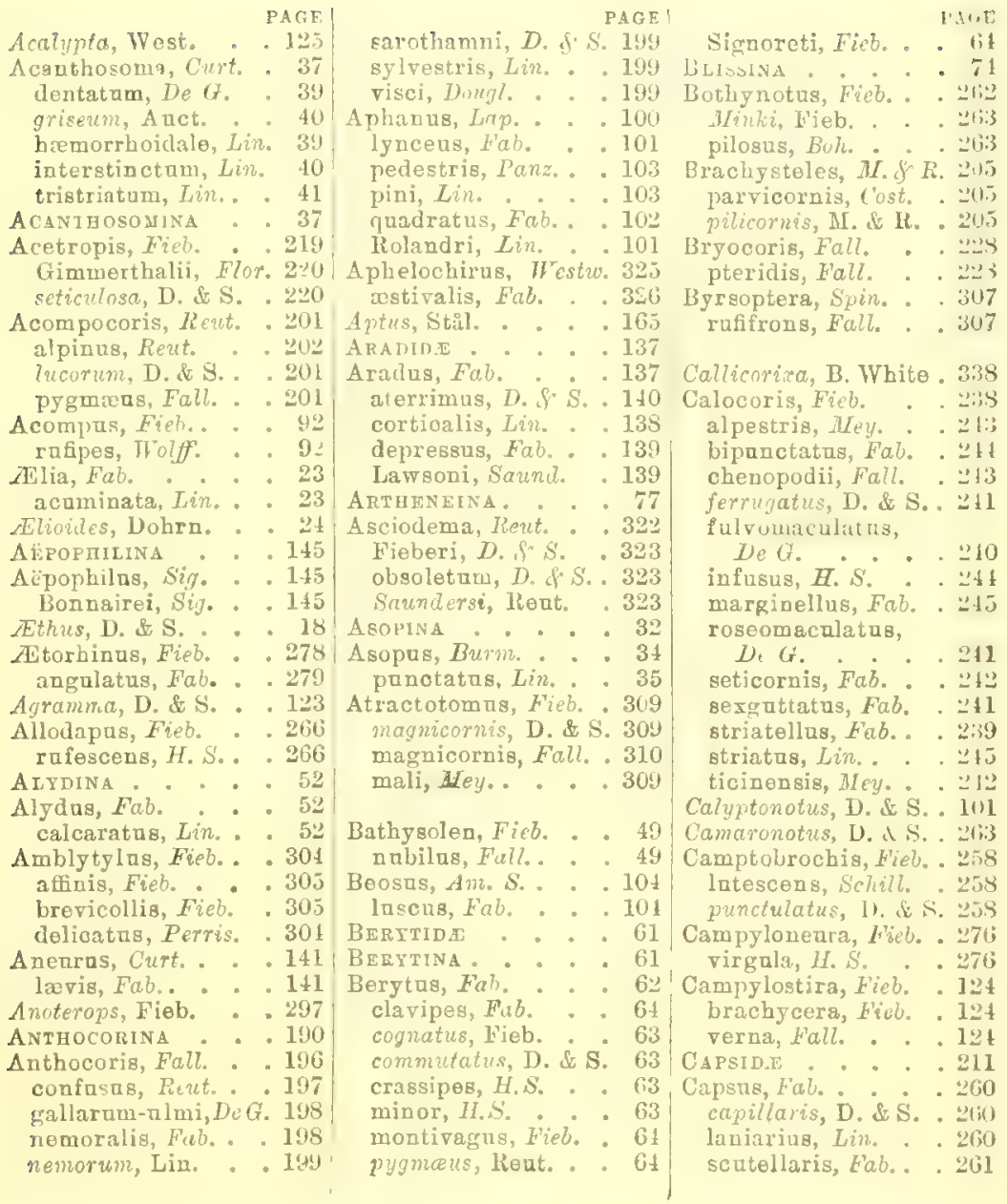


Cardiastethus, $D$, PAGF

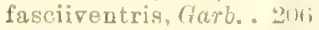
testaceus, D. \& S. : :111i

Carpocoris, Kol. . . :

Catuplatus, Spin. . . Iijt

Ceraleptus, Cost. . . . II lividns, Stein. . . in squalidus, D. \& S. . in

Ceratocombina. . I Ih

Ceratocombns, Sign. Isi coleoptratus, Zett. . In! muscomum, D. \& S. . 14!

Charanocleilus, Fieb. . 25;

Chilacis, Fieb. . . . 77 typhie, Perr. . . 7.

Chlamydatus, Saund. .'"'-

Chorosoma, Curt. . . (i) Schillingi, Schml, . (iu

Cimex, Lin. . . . 1לi colnmbarias, Jen, . ISi hirundinis, Jen.. . 1.5 lectularins, Lin.. I Iri pipistrelli, Jen. . . 145

Clutell, . . , 1אil

Clariclas . . . 1Mi

Conostathug, Fieb. . 23!1!) brevis, Reut. arisens, D. \& S. . roseus, Full.

salinus, J. Sahll. . : (10)

301

$\because(1)$

$\because: 01$

Coranus, Curt. . . li,strbapterus, $D e G$. . 1li:;

('olin?) ?

(') CIEINA

Coreas, $F a b$.

denticulatng Scop. o linticarnis, D. \& S. . . I

Corimelrena, 117 ite scarabeoides, Lin.

CorIsID.E. $32:$

Corixa, Genfr. . . . 3:il afinis, Leach. . . 333 alpestris, D.\& S. . 311 atomaria, 111.

Boldi, D. $\{\cdot S$.

Bonsdorffi, Sahbor.

borealis, D. \& S. . 337

carinata, Selilb.

cavifrons, Thoms.

cograta, $D$. \& $S$.

coleoptrata, l'ab.

concinna, Fel.

decon $\alpha, \mathrm{D}$, \& $\mathrm{S}$.

distincta, Fieh.

Dourlasi, Fieb.

dulia, D.\& S.

I'abricii, Fieb.
Fallenii, Fieb.

PAOFI

fossaram, Leach . . ....

Geottroyi, Leach. . 3i:

hieroglyphica, Duf. 331.

intricutu, D. \& S. .340

limitata, Fieb. . . 336

Linnai, Fieb. . . 335

lngubris, Fie\%. . . 33t

micans, D. \& S. . . 337 ,

moesta, ficl. . . . 331

nigrolineata, Fieb. . 337

P'anzeri, Fieb. . . 333

perplexa, D. \& S. $\quad 337$

preasta, Fieb. . 33!

prominula, Thoms. . 3is

Sahlbergi, Fieb. . . 3335

Scotti, Fieb. . . 338

semistriata, Fieb. . 333

Sharpi, D. \& S. . . 310

sodalis, D. \& S . . 3339

socia, D. \& S. . . . 3339

Stăli, Fieb. . . 3333

striata, Lin. . . . 335

venusta, $D$. \& $S . \quad, 3337$

Whitei, D. \& S. . . 337

Wollastoni, D. \& S. 33\%

Corizina . . . 55

Corizas, Fall. . . 56'Elasmostethus, Fieb. . 41

abutilon, Ross. . . 56| Elatophilus, Rent. . 1:45

capitatus, $F a b . ~ .58$ nigricornis, Zett. . 1:1,

crassicornis, Lim. . 56 Emblethis, Fieb. . . 10,

macrlatas, Fieb. 57 verbasci, Fab. . . 105

parampunctatus, EMESINA. . . 1Sis

Schill. . is Enoplops, Am.S. . 41

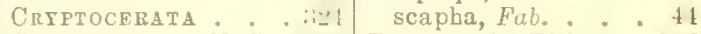

Cryptostemma, H. S. . 1.: Eremocoris, Fieb. . . 106

alienum, H. S. . . 1.: erraticus, D.\& S. . 107

CIDNINA . . . 17 fenestratus, U. S. . 107

Cyllocoris, Faln.. . 2T⿱ plebeius, Full. . 108 Havonotatus, Boh. . Zis podagricus, Fab. . 107

histrionicus, Lim. . 27. pola, 7 ricus, Saund. . 107

Cymatia, Flor. . . : Ill Eroticoris, D.\& S. . "̈rito

CrMNA . . . T1 Eurygaster, Lap. . 16

Cymus, Hahn. . . 71 mara, Lin. . . 16

claviculas, Fall. . . 7: nigra, Fub. . . 16

glandicolor, Hahn. 71 Eysarcoris, Hahn......

melanocephalus, Fieb. 72 xoneus, Scop. . . . 26

Cyprostethus, Fieb. - $\$ 1$ melanocephalus, $\mathrm{Fab} .25$

311 Cyrtorrhinas, Fieb. 28:

310 caricis, Fall. . .283

34 Haveolus, Rent. : 384 Gastrodes, Westw.. . 118

:16 insignis, D. \& S. . 283। abietis, Lin. . . 118

33. pygmas, Zett. . .283 ferrmgineus, Lin. . 118
Derephysin, Spin. . 130 foliacea, $F a l l$. . . 130
Geotomas, $I T$, \&, 18

lavis, D. \& S. . . 18

punctulatus, Cost. $1 \mathrm{~s}$ 


\begin{tabular}{|c|c|c|c|c|c|}
\hline & PAGE & & & & PAGE \\
\hline Gerris, $F a b$. . . . & .151 & stagnornm, Lin. . & .148 & limbatus, Fall. . & .251 \\
\hline argentata, Schum. & .157 & HYDROMETRIDE. . & .114 & lucornm, Mrey. & .251 \\
\hline aspera, Fieb. . . & .155 & HYDROMETRINA. . & 147 & pabulinus, Lin. & 19 \\
\hline$\infty, I I . S$. & $.15 t$ & Hygrotrechus, Stal. . & .152 & pastinace, Fall. & \\
\hline Era, Scluum. & .156 & Hypsitylus, Fieb. & .242 & pratensis, Fab. & \\
\hline ris, Lin.. & .156 & bicolor, $D$. \& $S$. & .202 & rubricatus, Fall. & \\
\hline De $G$. . & .154 & chloropterus, D. \& & 290 & 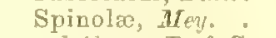 & \\
\hline ogaster, Zett. & & & & $s, \mathbf{D}, \& \mathbf{S}$. & \\
\hline Fab. & .351 & IdnTocoris, D. \& $\mathrm{S}$. & .272 & riridis, Fall. . . & \\
\hline tellata, Latr & & Ischnocoris Fieb. & $\begin{array}{r}87 \\
87\end{array}$ & viscicola, Put. & \\
\hline sa, Thoms. & 340 & hemipterus, D. \& S. & & Macrocoleas, Fieb. & \\
\hline , Latr. & .279 & Qemas, Fieb. & & us, Mey. & \\
\hline$B S$ & .281 & ti, Fall. & & lus, Fall. & \\
\hline Reut.. & .281 & nchus, Fie & & ti, Fall. & \\
\hline h. . . & .281 & & & a, Thoms. & \\
\hline itus, $\mathrm{Fa}$ & & Fieb. & & a, Fieb. & \\
\hline us, & & reselta, D. \& S. . & & rum, & \\
\hline arud. & $\begin{array}{l}281 \\
.281\end{array}$ & resedæ, Panz.. & 73 & sas. ${ }^{\text {s. }}$. Sch.. & \\
\hline Fieb. & .280 & Jalla, Hahn. & & lus, Fieb. & \\
\hline Hnathoconns, Fieb. & .21 & dumosa, Lin. . & & i, Fall. & \\
\hline & 21 & & & , Dley. & \\
\hline & . 21 & Labops, Barm. & & Malacocoris, Fieb. . & \\
\hline Latr. & . 47 & oplax... & & ns, Fall. & \\
\hline$a b \ldots$ & . 47 & Lasiosomus, Fieb. & & Fieb. & \\
\hline ltus, Stal. . & .101 & is, H.S. . & . 91 & s, Fall. & \\
\hline NOCERATA . & . 13 & Leptopterna, Fieb. & .226 & coelum, Fieb. & \\
\hline eb. & .255 & , Fall. & .227 & $\begin{array}{l}\text { cercea, Fineb. } \\
\text { tica, } \operatorname{Lin}, .\end{array}$ & \\
\hline$m$. & .267 & , Stial. & & ornis, Fall. & \\
\hline & 68 & Lim & & ais, Fonte. & \\
\hline Panz. & .267 & Liocoris, Fieb. . & .259 & ia, $M . \& \cdot R$. & \\
\hline Curt. & .306 & trij & & $A, M I S R$. & \\
\hline all. & & & & INA. & \\
\hline$\therefore$ & $\cdot 142$ & Lopns, Hahn. . & .231 & THENA. & \\
\hline Curt. & .112 & omarginatus, $D^{h}$ & 232 & Metacanthus, Cost. . & \\
\hline ag, Fall. & & gc & & , Germ. & \\
\hline 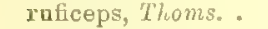 & . 143 & \& S. . & & pis, Fict. . & \\
\hline INA & .75 & Fieb. & & rafescens, $H . S$. & \\
\hline pin. & 75 & ciliosus, D.\& & & a, $\mathbb{U}$ costw. & \\
\hline $\mathrm{R}=\mathrm{x}$ & 76 & Lex & & & \\
\hline & & & & & \\
\hline Heterocordylus, Fie & 6.295 & Lyctocoris, Hahn. . & .191 & PIIYSINA . & \\
\hline & & cal & & velia, IVest. & \\
\hline & & & & aca, Duf. & \\
\hline & .296 & $\operatorname{IDE} \cdot$. & & Miridius, Fieb. . & \\
\hline & & LTGEINA 。 & & virigatas, & \\
\hline Schill. & . 78 & Lygaxus, Fab. . & & Costa. & \\
\hline Schilll. & .79 & equestris, Lin. & 69 & Miris & \\
\hline & . 78 & Lygus, Hahn. . & $\because 18$ & calcaratus, Fall. . & \\
\hline GASTRINA . & . 78 & atomarins, Ney. & 255 & holsatus, Fab. . & \\
\hline Latr. . & .294 & campestris, Fab. & 252 & lerigatus, Lin. . & \\
\hline & & cervint & & Monalocoris, Dahlb. & \\
\hline Toplomachus, Fieb. & .301 & contaminatns, D & 250 & filicis, Lin. . . & \\
\hline 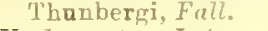 & & contaminatus, & & uthia, Lep. & \\
\hline Hzdrometra, Latr. & .117 & Kalmii, Lin. . . . & & ampliata, Fieb. . & \\
\hline
\end{tabular}




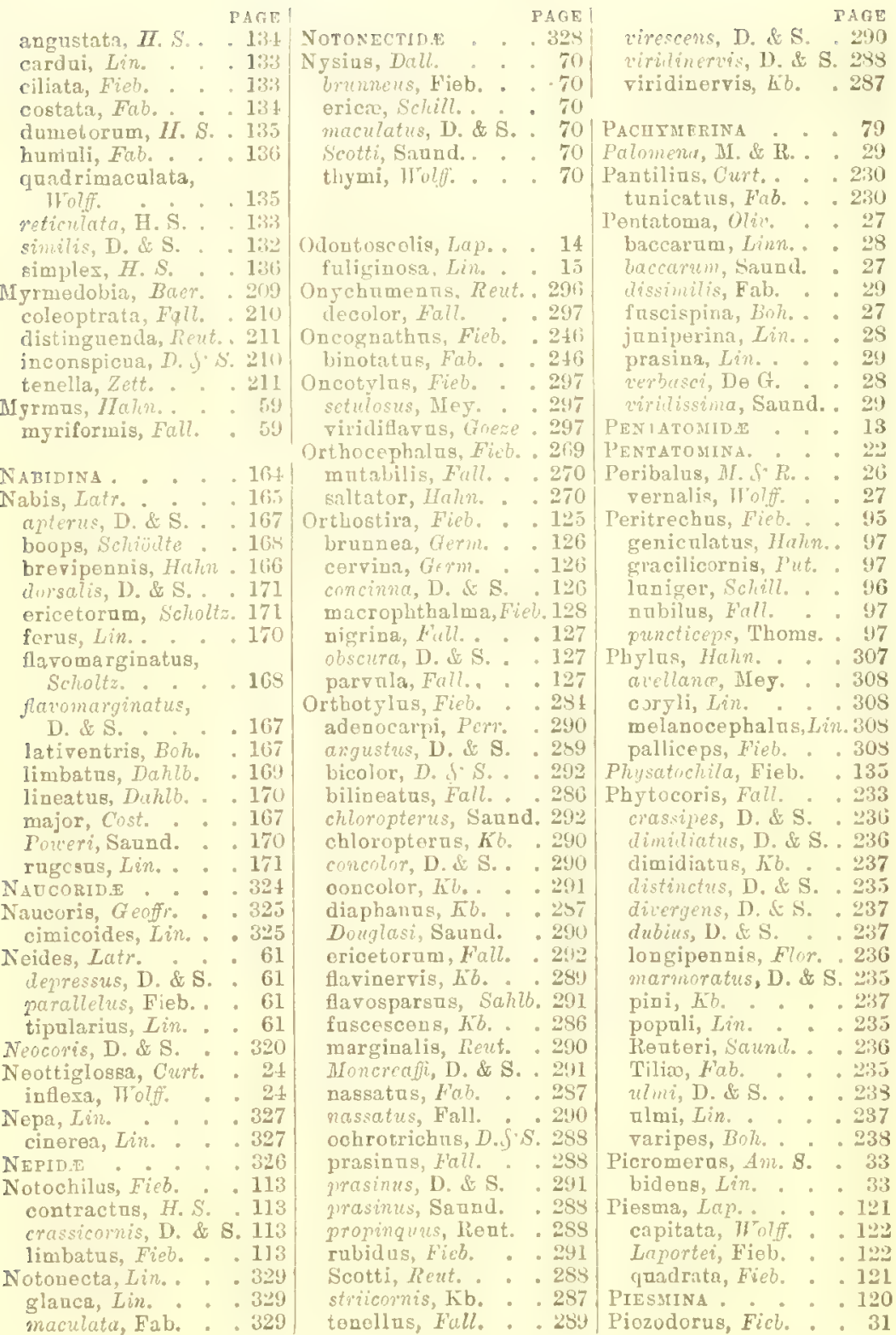


PAGE

lituratas, Fab., Stal. ;1 purpureipennis, D. . 3]

Piezostethns, Fieb. . 19: cursitaus, Fall. . . 1!: formicetorum, Boh. 1!t galactinus, Fieb. . 11\}3 rufipennis, D. \& S. . 191;

Pilophoras, HWhn, . . 24, ${ }^{2}, 3$ cinnamopterus, hb. "2ht clavatus, Lin. . . 2014 perplexus, Scott . . $26 \%$

Pionosomag, Fied. . 8! varias, Holfi. . . . 8!

Pithanus, Fieb. . . 218 Maerkeli. H.S. . . 219

Plagiognathus, Fieb. . 318 albipennis, Fall. . 319 arbustorum, Fab. . 320 Bohemanni, Full. . 321 nigritalus, Full. . . 3:1 pnlicarins, Fall. . . 3니 lioseri, II. S. . . 3Iy galtitans, Fall. . . 32: Scotti, Fieb. . . 3*1 viridulas, Fall. . . 32\}) Wilkinsoni, D. \& S. 3\%" Platychila, Fieb. . . 1:3: Ples, Leach . . . 32( mintatissima, Fab. . 3:30

Plesiocoris, Fieb. . . 217 rugicollis, Fall. . . 214

Plesiodema, Ferst. . . B.s pinetellum, Zett. . 304

Plinthisas, Fieb. bidentulus, H. S. brevipennis, Latr.

Plociomerts, Say. Iracticollis, Schill. . 82 luridus, Hahn.

Ploiaria, Scop. oliciformis De G. 10 erratica, D. \& S. . 159 vagabunda, Lin.. . 159

Podisus, $I$. S. luridas, $F a b$. . . . \$1

Podops, Lap. innucta, Fab. 17

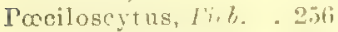
Gyllenbalij, Fall. . 256 nigritus, Fall. . . .257 anifasciatas, Fab. . 2us

Prostemma, Lap. . . I61 guttula, Fab. . . 1ff

Psallns, Fieb. . . 3I0 albicinctas, $K b$. . 316 alni, D.\& S. . . .315 aldicola, $D . \& S$. . . 315
PAGE antimune, D. \& S. . \$11 ambiguns, Fill. . : 31 . betuleti, Fall. . .311 dilutus, D.\& S. . . 310 diminutas, $K b . \quad$. . .31f ristinctus, D. \& s. .316! Falienii, hent. . .311 Kirschbanni, Sannd. 315 lepidus, Fieb... . 315 ohsenrellus, Fall. . 312 obscurus, 10. \& S. . 31* pini, D. \& S. . . 312 pityophilus, Elor. . 312 querceti, Fall. . . 317 quercûs, $h b . . .313$ roseus, D. \& S. . . 315 roseus, Sanad. . . 31t Lotermundi, Schltz. 314. salicellus, Mey. . . 317 salicis, Fieb. . . 314. sanguineus, $\mathrm{Fab}$. .317 simillimus, D. \& S. 313 variabilis, Fill. . . 313 variane, $H$. S. . . 31ti Whitei, D. \& S. . . 313 Pseudophleas. Burm. . 48 Fallenii, Schill. . 48 Pseudophleps, 1). \& S. 209

Pycnopterna, Fieb.. . 245

Pygolampis, Germ. . 160 bidentata, Finre. . 161 bifurcata, $\mathbf{U}$. \& S. . 161 PXRRHocorina . . 119 Iyrrhocoris, Full. . . 110 apterus, Lin. . . 12u

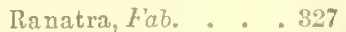
linearis, Lin. . . . 328 REDETIIAE . . 157 Redurina . . . 160 Reduvins, Fab. . . . 161 personatus, Lin.. . 162 Rhacoinathus, Fieb. . 31 Rhopalotomus, Fied. . 261 ator, $l_{i n} . . .262$

Rhy parochromus, Curt. 8 ; antenzatug, Schill. . 8.. chiragra, Fab. . . 84. dilatatus, $\boldsymbol{I I}$. S. . 83 pratextatas, $I I, S$. . sabulicola, Thoms. . 84

Salda, Fab. . . . .173 aronicola, Scholtz. . 182 C-albam, Hicb. . 178 cincta, $H . S . ., 181$ Cooksi, Curt." . . $183 \mid$ Straobia, Uahn. . . 29 conspicua, D.\& S. .175 elegantula, D. \& S. . 1k3 elecantula, Full. . 1\{i:\} Flori, Dohru. . . ] Bis fucicola, D. \& S. . 180 lateralis, Fall. . . 175 littoralis, Lin. . .177 marginalis, fall. . 180 maryinella, D. \& S. . 150 morio, Zett. . . 178 opacula, $Z$ tt. . . 179 orthochila, Fieb. . 176 pallipes, Fab.. . . 181 palustris, Dougl. 181 pilosa, Fall. . . . 174 piloscila, Thoms. . $\mathbf{1 8 1}$ pulchella, D \& S. . 175 rimeria, D. \& S. . 177 riparia, Full.. . 175 saltatoria, Lin. . 180 scotica, Curt. . 177 stellata, Curt. . . 178 vestita, D. \& S. . . 180 SALDIDE . . . . 17:

Sciocoris, Fall. . . 2 22) oursitans, Fab. . . 23 Scolopostethus, Fieb. . 104 adjunctus, D. fo S. . 111 affinis, Schill. . 111 decoratas, Hahm. . 112 cricetorum, Letb. . 112 grandis, Hor $\%$. . 111 neglectus, $E d w . .112$ pictus, Sclitll. . 111 puberalus, Horv. .112 punctatus, Edw. . 110 SCUTELLERINA . . $\quad 14$ Sobirus, Am, S. . . 18 bicolor, Lin. . . 19 biguttatus, Lin. . . 20 dubins, Scon.. . 19) morio, Lin. . . . 20 Serontbia, Slin. . . 1:3:3 lota, Fall. . . . 12:3 Sigara, Fab. . . . . 313 minutissima, Iin. . 31* Scholtzii, Fieb. 34.7 Spathocera, Stein. . . 43 Dalmanni, Schill. . 43 Spliyracenhalus, D.\& S. 282 STENOCEPIIAIINA . . 5: Stenocephalus, Latr. . $5: 3$ agilis, Scop. . . . 5i3 neglectus, $I I$. S. . 51 Sthenams, Fieb. . 31! Stipltresonia Fieb. 


\begin{tabular}{|c|c|c|c|c|c|}
\hline & & & PAGE: & & PAGF \\
\hline a, Lin. . . & 30 & antennatus, Boh. & .2235 & rufipos, Lin. . & - 32 \\
\hline cea, Lin. & - 30 & si, D. S S.. & - 226 & Tropistethus, Fieb. & \\
\hline$a, \mathrm{D}, \& \mathrm{~S}$. & & D.S S... & .225 & Josericeus, Schlt & \\
\hline trongylocoris, Costa. & 265 & epa, Eieb. & 200 & Tytthus, D. \& S. . & \\
\hline $\mathrm{ug}, \operatorname{Lin}$. & 2. 264 & Fiet.. & . 200 & & \\
\hline ,Fall.. . & .260 & Therapha, $1 \mathrm{~m}, S$. & - 55 & Velia, Latr. . & 48 \\
\hline tygnus, Fieb. & - $\quad \$ 13$ & hyosc уаті, Lin. . & - $\quad \mathbf{5 5}$ & currens, $F a b$. & \\
\hline rias, $\Pi a h u$. & 91 & TINGIDIDAE • & 120 & VELIINA $\therefore$. & \\
\hline Fieb. & & TINGIDINA. & & Verlusia, Śpin. . & \\
\hline १. . & & Trapez & & mbea, Lit & \\
\hline & & $\mathrm{ag}$ & & & \\
\hline ill. & & dispar, Stål. . & 99 & , Sti̊l. & \\
\hline tes, Latr. . & 45 & distinctus, D. \& S. & 98 & is, Duf.. . & \\
\hline & & Fieb. & & & \\
\hline & & Triphleps, Fieb.. . & & Zicr & \\
\hline & & $\begin{array}{l}\text { oulus, Reut. } \\
\text { as, Lim. }\end{array}$ & & $\begin{array}{l}\text { ea, Lin... } \\
\text { es, Lap.. }\end{array}$ & \\
\hline & 0.1 & $\begin{array}{l}\text { viger, Whlft: } \\
\text { olscurus, D. \& S. }\end{array}$ & $\begin{array}{l}203 \\
-214 \\
214\end{array}$ & $\begin{array}{l}\text { Zygimus, Fieb. } \\
\text { pinastri, Fall. }\end{array}$ & $\cdot$ \\
\hline
\end{tabular}

\section{ADDENDA AND CORRIGENDA.}

pp. 43, 48, and Expl. pl., for Pseudophleeus, read Pseutophtous.

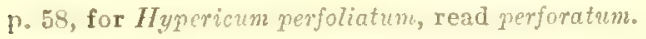

p. 63, undor Berytus crassipes, for "one species," read "one specinen."

p. 110 , table of species, for punctatus, read grandis.

p. 127, add as synonym to Orthostira parrala, Fall., obscura H. Schff. D. \& S. \&c.

p. 210 , line 12 from top, in some copies add + at commencement of paragraph.

p. 238 , for Deroecoris, D. \& T., read D.\& S.

p. 260, add as syuonym of Capsus laniarius, capillaris, Fab.

Illnstrated Edition, Pl. VI., fig. 4. Tho clubs of fomora and antennw should be black. 


\title{
WORKS ON ENTOMOLOGY.
}

\author{
Dedicated, by Special Permission, to Her Mciesty Qucen Trictoria, \\ Empress of India.
}

Now Ready, Vol. I., with 94 Coloured Plates, cloth, $£ 9$ 5s.; half-morocco, gilt tops, $£ 9155$ s.

Lepidoptera Indica. By F. Moore, F.Z.S. 4ito. In parts, with Coloured Plates, 15s, each. Prospectus on Application.

Now Ready, complete in 1 Vol., with a Structural Plate, 14s.

The Hemiptera-Heteroptera of the British Islands. By EDWARD SAUNDers, F.L.S. LARge PAPER Illustrated Edition with 31 Coloured Plates, 48 .

The Lepidoptera of the British Islands. By CHatues G. Barretr, F.E.S. Large Paper Illustrated Edition with Coloured Plates, in monthly Parte, 5s, each. Prospectus on application.

The Coleoptera of the British Islands. A Descriptive Account of the Families, Genera, and Species indigenous to Great Britain and Ireland, with Notes as to Localities, Habitats, \&e. By the Rev. CANON FOWLER, II A., F.L.S. With two Structural Plates and Wood Engravings, complete in 5 Vols., $£$ !. Large Paper Illustrated Edition, with 180 Coloured Plates, containing 2300 figures, $£ 14$ net.

The Butterflies of Lurope; Illustrated and Described. By HenRY Chardes Lang, M.D., F.L.S. Complete in 2 Vols, super-royal 8vo, with 82 Coloured Plates, containing upwards of 900 figures, cloth, f:3 18s.

* The Stgtematio List of Europeas ButTerfireg from the above vork separately, price $8 d$. ; or printed on one sile of the paper only for Labels, ls.

The Lepidoptera of Ceylon. By F. Moore, F.L.S. 3 Vols., Medium 4 to, 215 Coloured Plates, cloth, gilt tops, £21 12s. Published under the auspices of the Government of Ceylon.

British Insects. A Familiar Description of the Form, Structure, Habits and Transformations of Insects. By E. F. STAveley, Anthor of "British Spiders." With 16 Coloured Plates and numerous Wood Engravinga, 14s.

British Beetles; an Introduction to the Study of our Indigenous Coleoptera. By E. C. RYE. 2nd Edition, revised by Rev. Canon Fow Ler. 16 Coloured Steel Plates, and 11 Wood Engravings, 10 s. $6 d$.

British Bees; an Introduction to the Study of the Natural History and Economy of the Bees indigenous to the British Isles. By W. E. ShockHard. 16 Coloured Plates, and Woodcuts of Dissections, $10 s .6 d_{\text {s }}$

British Butterflies and Moths; an Introduction to the Study of our Native Lepidoptera. By H. T. Stanton. 16 Culoured Plates, and Wood Engrarings, 10s.6\%

L. REEVE \& CO, 6, HENRIETTA STREET, COVENT GARDEN. 
British Spiders; an Introduction to the Study of the ARANEID F found in Great Britain and Ireland, By E. F. StaveleY. 16 Coloured Plates, and 44 Wood Engrarings, 10s. Gu.

Harvesting Ants and Trap-door Spiders; Notes and Observations ou their Hahits and Dwellings. By J. T. Moggridge, F. L.S. With Supplement, $17 s$. The Supplement separately, cluth, $7 s .6 u$.

Curtis's British Entomology. Illustrations and Descriptions of the Genera of Insects found in Great Britain and Ireland, containing Coloured Higures, from Nature, of the most rare and beautiful species, and in many instances, upon the plants on which theg are found. 8 Vols. Logal 870,770 Coloured Plates, $\mathfrak{L}_{2} \mathrm{~S}$.

\section{Or in Separate Monographs.}

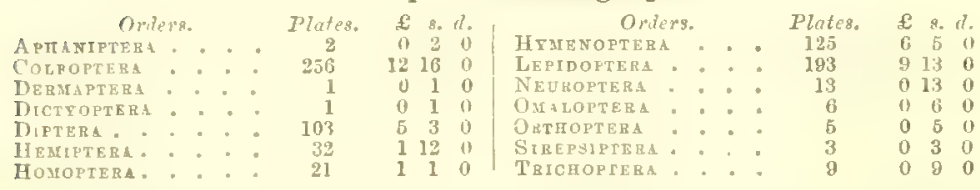

"Curtis's Eutomology," which Curier pronounced to have "reached tho altimatum of perfection," is still the standard work on the Gera of British Insects. The Figures executed by the author himself, with won: derful mianteness and accuracy, have never been surpassed, even if equalled. The price at which the work was originally pablished was ¿t3 16s.

The Structure and Lifo History of the Cockroach (Periplaneta Orientalis). An Introduction to the Study of Insects. By L. C. MraLL, Profossor of Biology in the Yorkshire Conlege, Leeds, and ALFRED Denny, Lecturer on Biology in the Firth College, Sheltield. 125 Woodcuts, $7 s .6 i d$.

\section{Just Published.}

The Physiology of the Invertebrata. By A. B. Griffitis, Ph.D., F.T.S.E. S1 cats, 1ús, net.

British Zooplytes; an Introduction to the Hydroida, Actinozon, and Polyzoa found in Great Britain, Ireland, and the Channel Iglands. By ArtuUe S. Pennington, F.L.S. 24 Plates, 10s. $6 d$.

Handbook of the Vertebrate Famma of Yorkshire; being a Catalogue of British Mammals, Birds, Reptiles, Amphibians, and Fishes, found in the County. By William Eagle and Wiliasi DENISON KOEBCCK. 8s. Gid.

L. REEVE \& CO., PUBLISHERS TO THE HOME, COLONLL, AND INDIAN GOVERNAENTS, 6, HENIRIETTA STREET, COVENT GARDEN. 



\section{PIAT'E I.}

Iru, 1. Odontoscelis fuliginosa, Lin.

2. Corimolena searabooides, Lin.

$\therefore$ Eurycraster maura, Lin.

1. , nigra, Ful.

¿) Podops inuneta, Fab.

4; Gentomus punctulatus, Cins/.

; Sehirus bicolor, Lin.

$\therefore$, dubius, $S$ copr.

$\because$, bientatus, Lin.

111 " morio, Lin. 

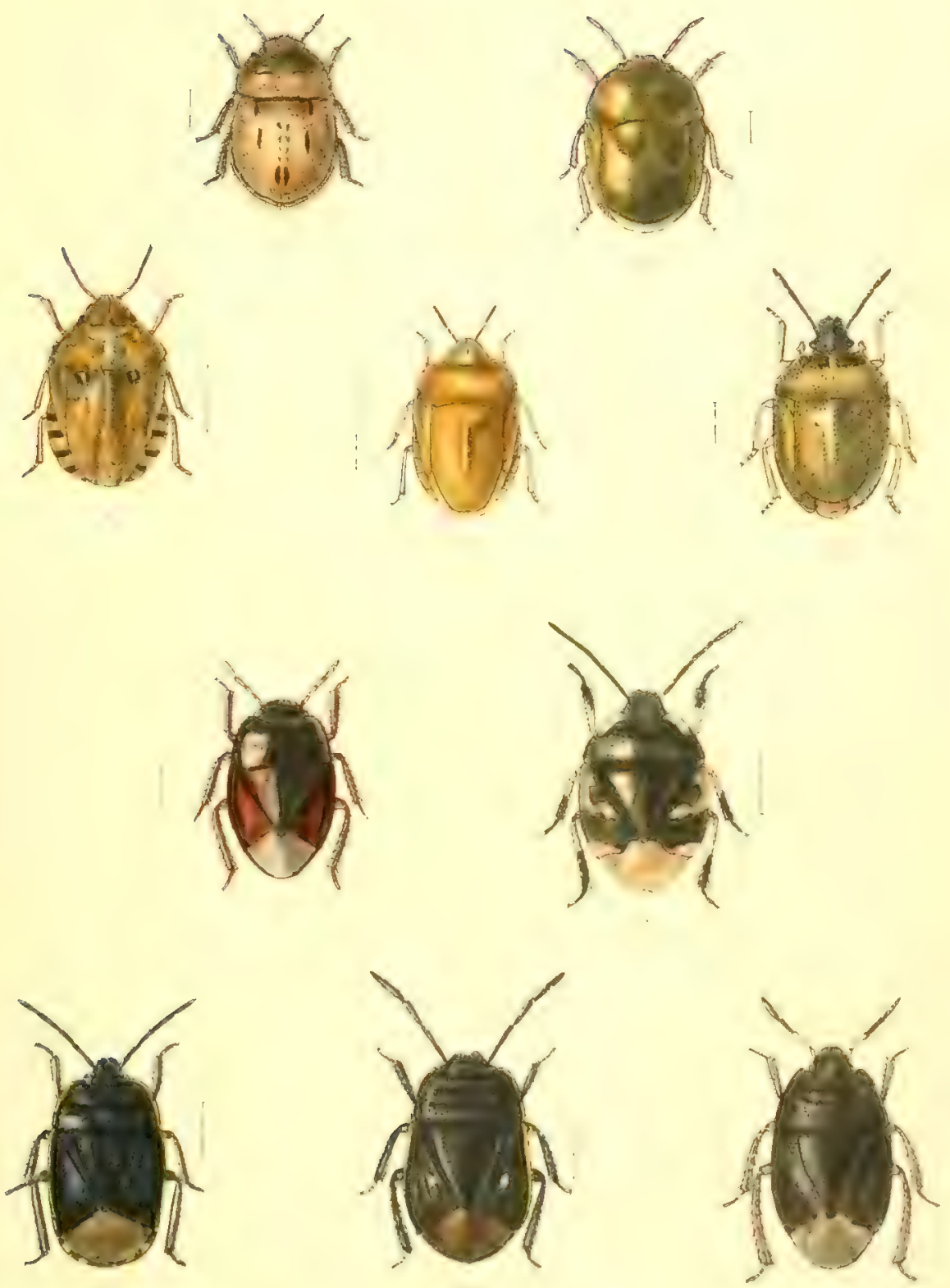

• 


\section{PLATE II.}

Fra. 1. Gnatho conus picipes, Fall.

2. Seiocoris cursitans, Fub.

3. Elia acuminata, Lin.

4. Neottiglossa inflexa, $\mathbb{W}$ olf.

5. Eysarcoris melanocephalus, ficb.

b.,$\quad$ xueus, Scop.

7. Peribalus vernalis, Wolti.

8. Pentatoma fuscispina, Boh.

y., baccartum, Lin.

10. " juniperina, Lin. 

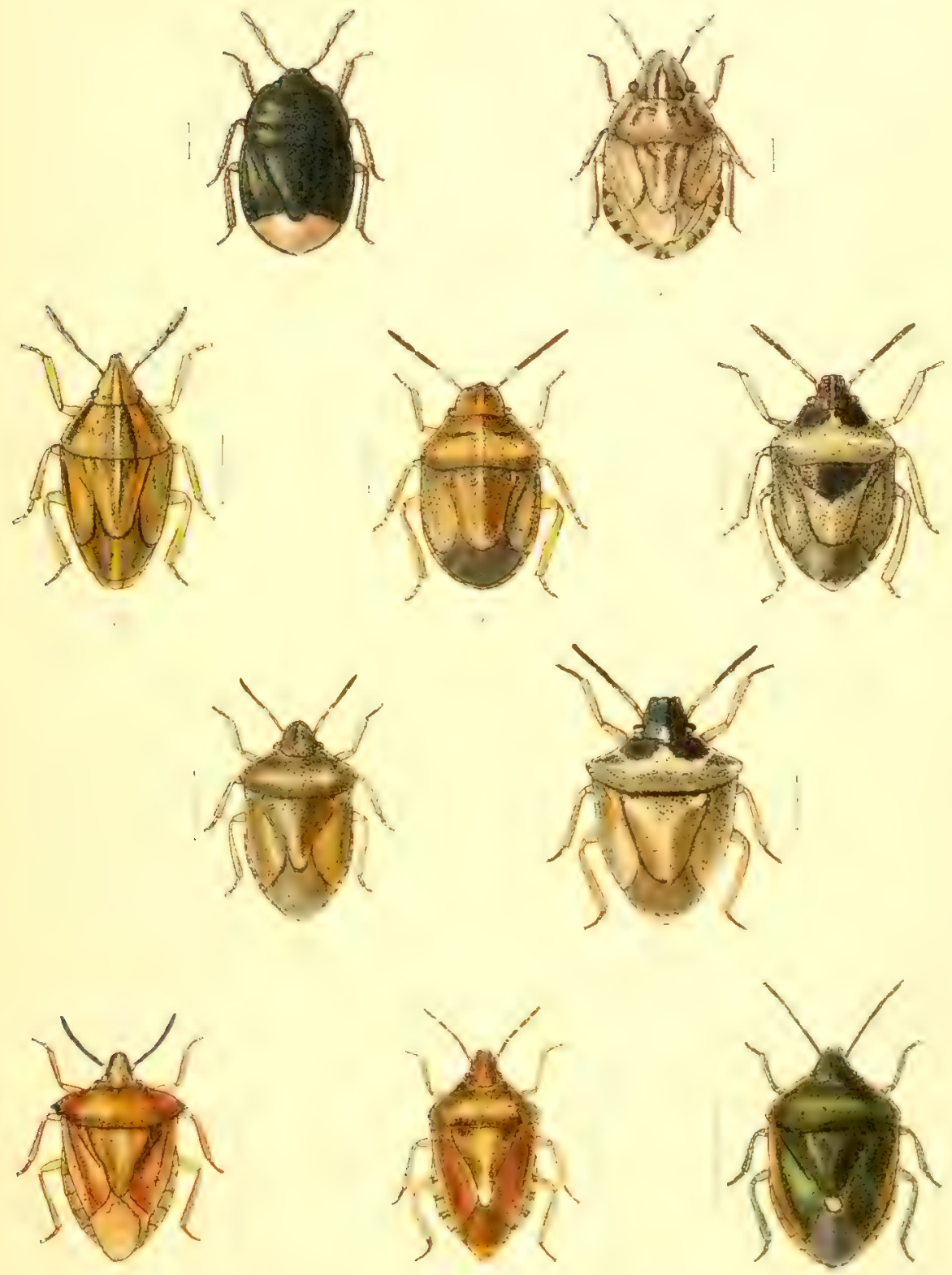




\section{PLATE III.}

Ire. 1. Pentatoma prasina, Liar.

2. Struchia festivit, Lin.

:i. ", oleracea, Lin.

4. Piezodorus lituratus, Fub.

$\therefore$ 'lropicoris rutipes, Lin.

i. Pieromerus bidens, Lin.

7. Podisus luridus, Fub.

- Asopus punctatus, Lin.

4. Jalla dumosa, Lin.

11). Zicrona corulea, Lim. 

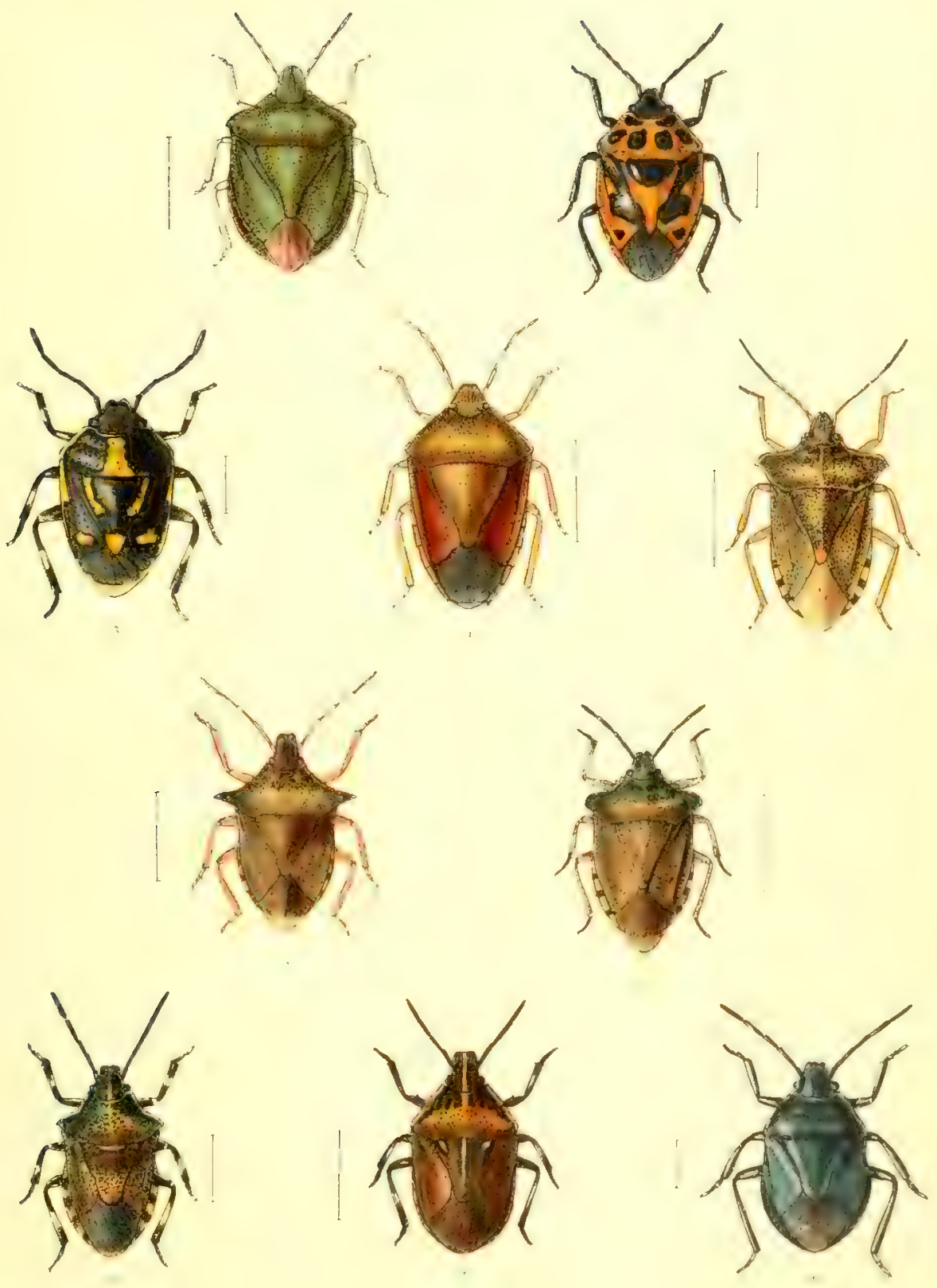




\section{PLATE IV.}

Fus. 1. Acanthosoma hemorrhoidale, Lir.

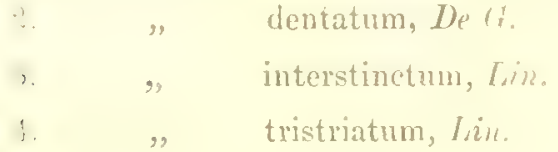

5. Spathocera Dalmanni, Schil.

i. Enoplops seapha, Fab.

i. Syromastes marginatus, Lin.

- Verhusia rhombea, Live

1) Gonocerus venator, Fib.

10 Pscudophlens Fallenii, Schit. 

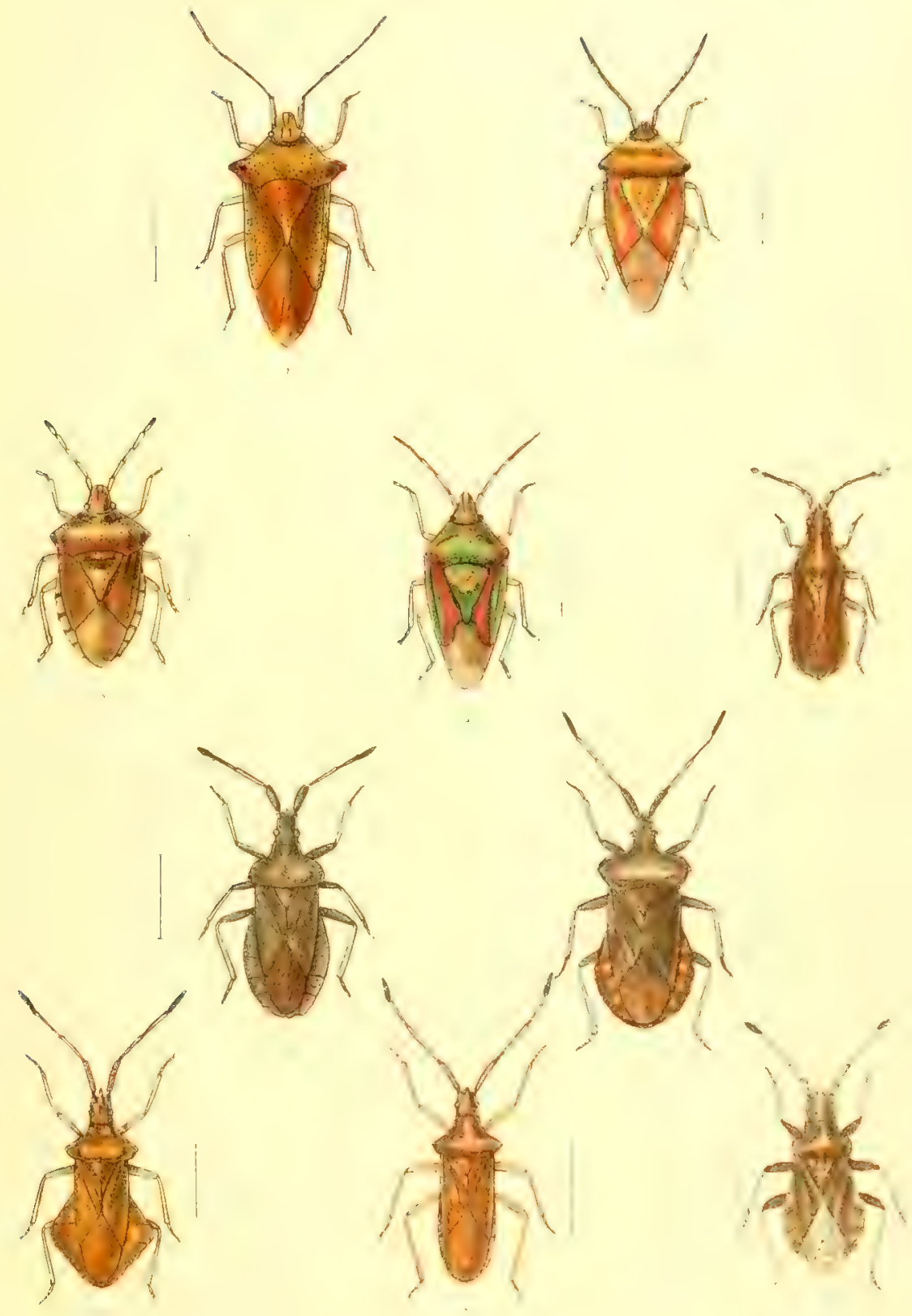

R Morgan del et Ltir 




\section{PLATE V.}

Fro, 1. Bathysolen nubilus, Fall.

2. Ceraleptus lividus, Stcin.

3. Coreus denticulatus, Scop.

4. Alydus calcaratus, Tinn.

f). Stenocephalus anilis, Scop.

6. Therapha hyoscyami, Limn.

7. Gorizus crassienrnis, Linn.

\&. "mactatus, liep.

@. " capitatus, Fal.

10. , parumpunctatus, schill. 

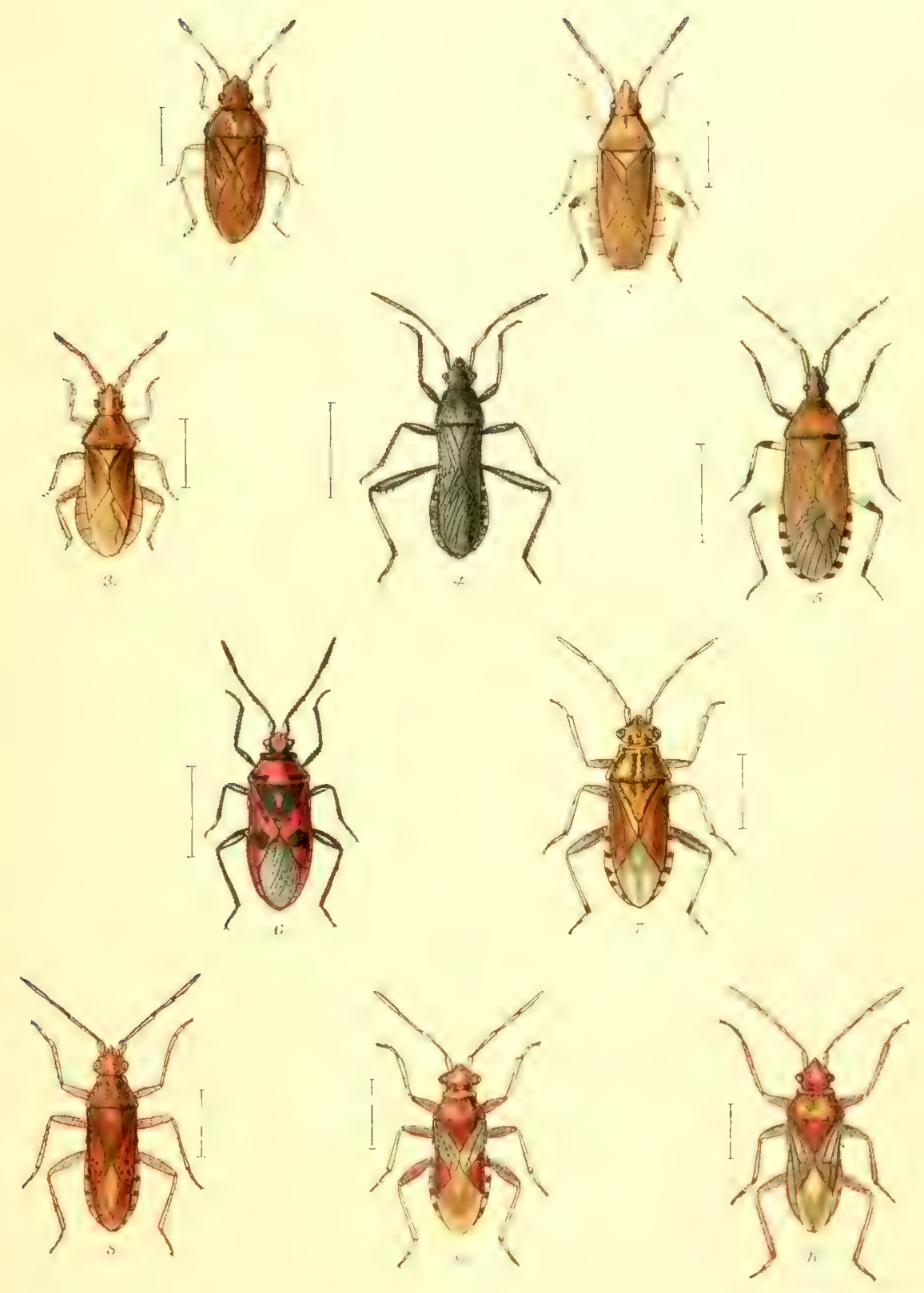

E. Morgan, del et lith 




\section{PLATE VI.}

Fis. 1. Myrmus miriformis brachypterous, Fill.

lia. " " q with developed ongtra.

2. Chorosoma Schillingi, Schm/.

$\therefore$ Neides tipularius, Linn.

4. Berytus crassipes, II. Schf.

i. ", clavipes, Fut.

10. Metatropis rufescens, $M$. Scht:

7. Metacanthus punctipes, Germ.

8. Lygras equestris, Lim.

9. Nysius ericx, Schill.

10. Cymus glandicolor, Hahn. 


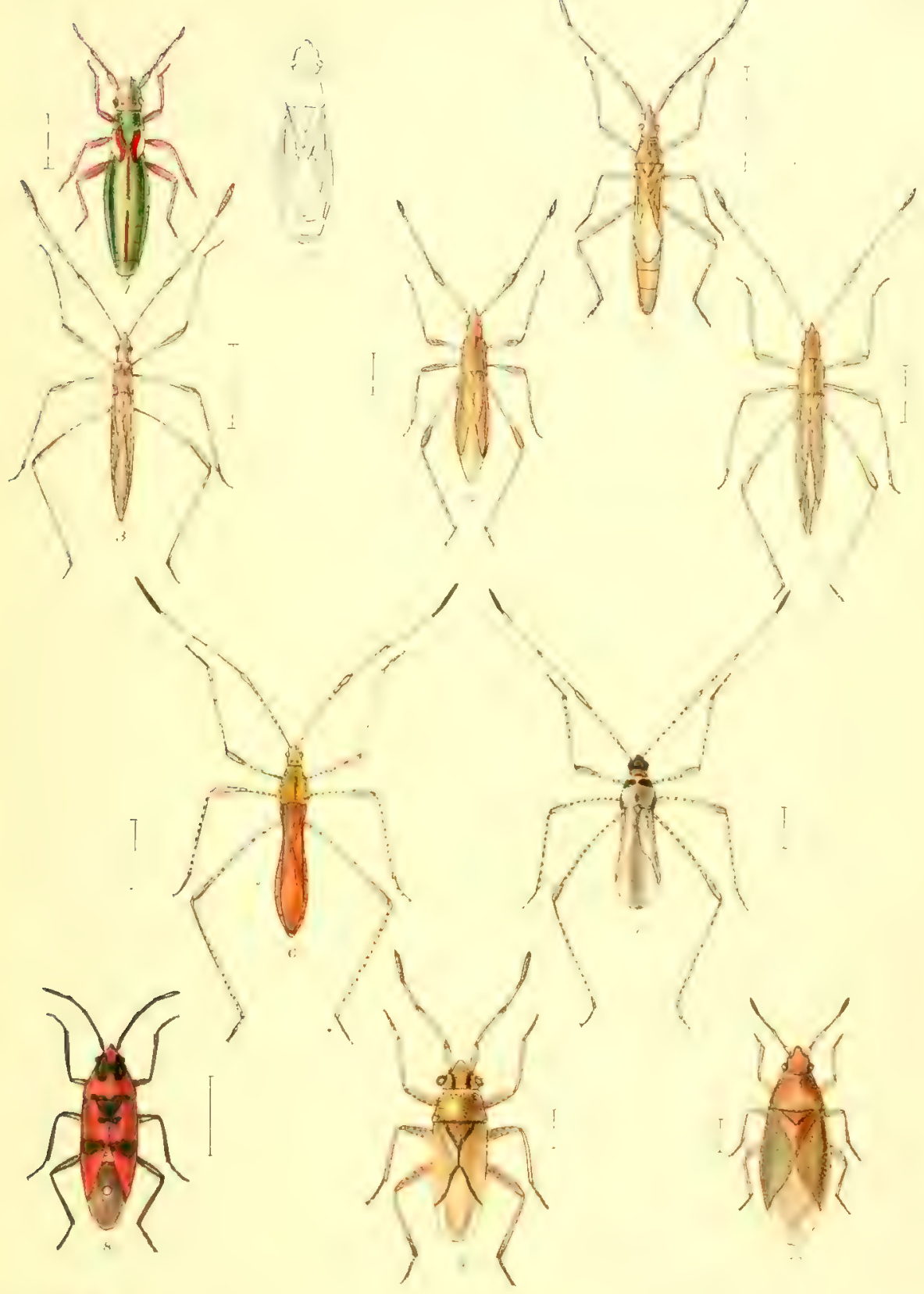

R.Morgan de? . ... 




\section{PYATE VTY.}

1. 1. Ischnorhynchus resedx, Prna

$\therefore$ Ischnodemus sabuleti, Fall.

$\therefore$ Henestaris laticeps, Curl.

1. „, halophilus, Burm.

¿. Chilacis typhr, Perr.

ii. Heterogaster artemisia, s'chill.

7. Plociomerus fracticollis, Schill.

-, luridus, Hahn.

9. Rhyparochromus antenuatus, Sclill.

11., pretextatus, H. Sich 


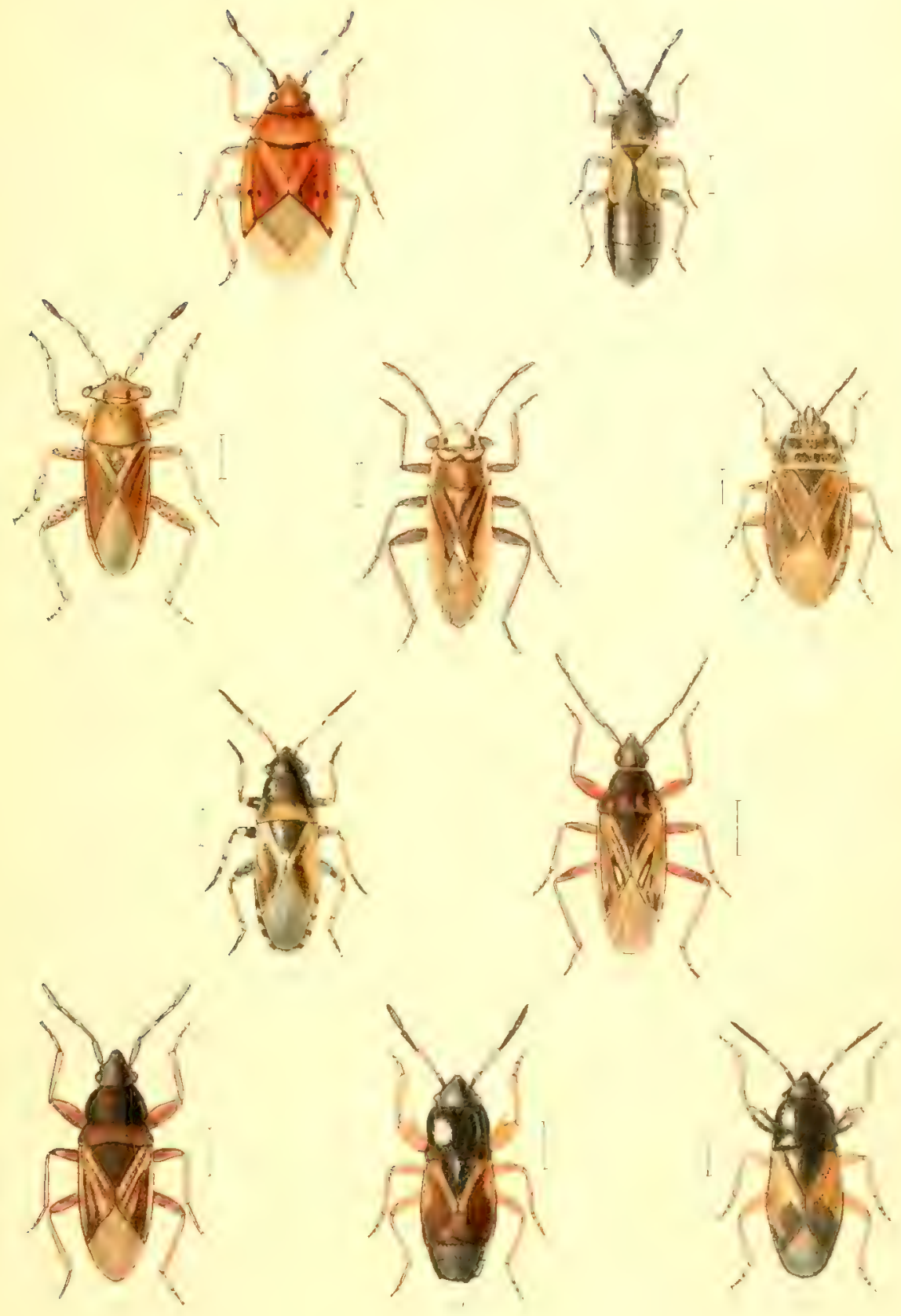






\section{PLATE VIII.}

liki. 1. Lhyparochromus chiragra, Eulh.

¿. 'Tropistethus holosericeus, s'chlt:.

$\therefore$ Ischnocoris angustulus, Boh.

1. Macrodema micropterum, C'urt.

5. Pionosomus varius, Wolf .

ii. Plinthisus brevipennis, Lutr.

7. Lasiosumus enervis, Ul. Schf:

S. Acompus rufipes, Wolit.

9. Nitynus arenarius, Halkn.

10. Peritrechus geniculatus, Huhn.

10a, . lateral view. 

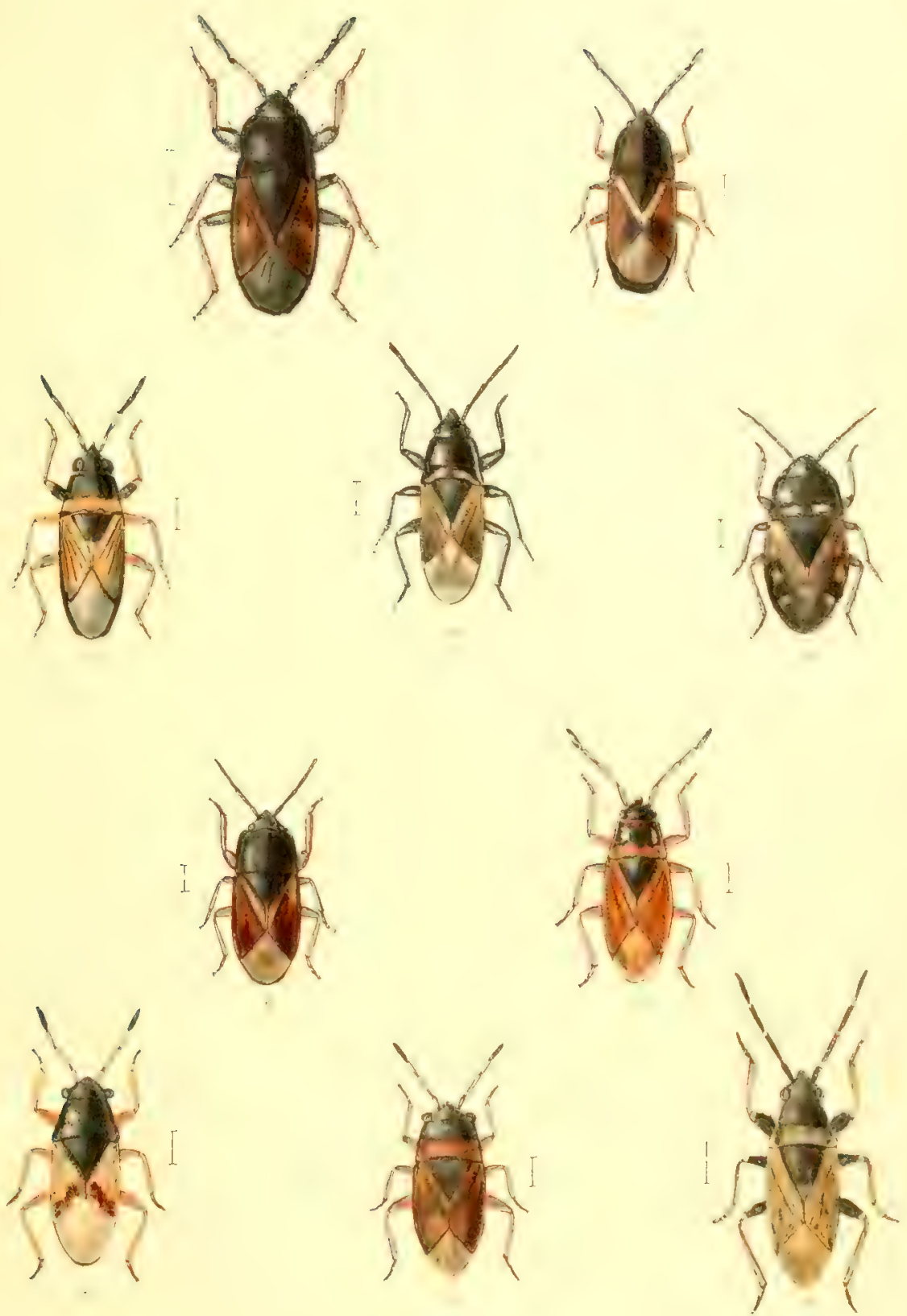



\section{PLATE IX.}

Fig. 1. Peritrechus nubilus, $F u l l$.

:. Trapezonotus distinguendus, Flor.

3. ... Ullrichii, Fiel.

1. Aphanus Rolandri, Limn.

5. " lynceus, Filb.

6. " pini, Linn.

7. , quadratus, Fal.

$\therefore \quad$ " pedestris, Panz.

औ. Emblethis verbasci, $H$. Schf.

10. Beosus luscus, Fab. 


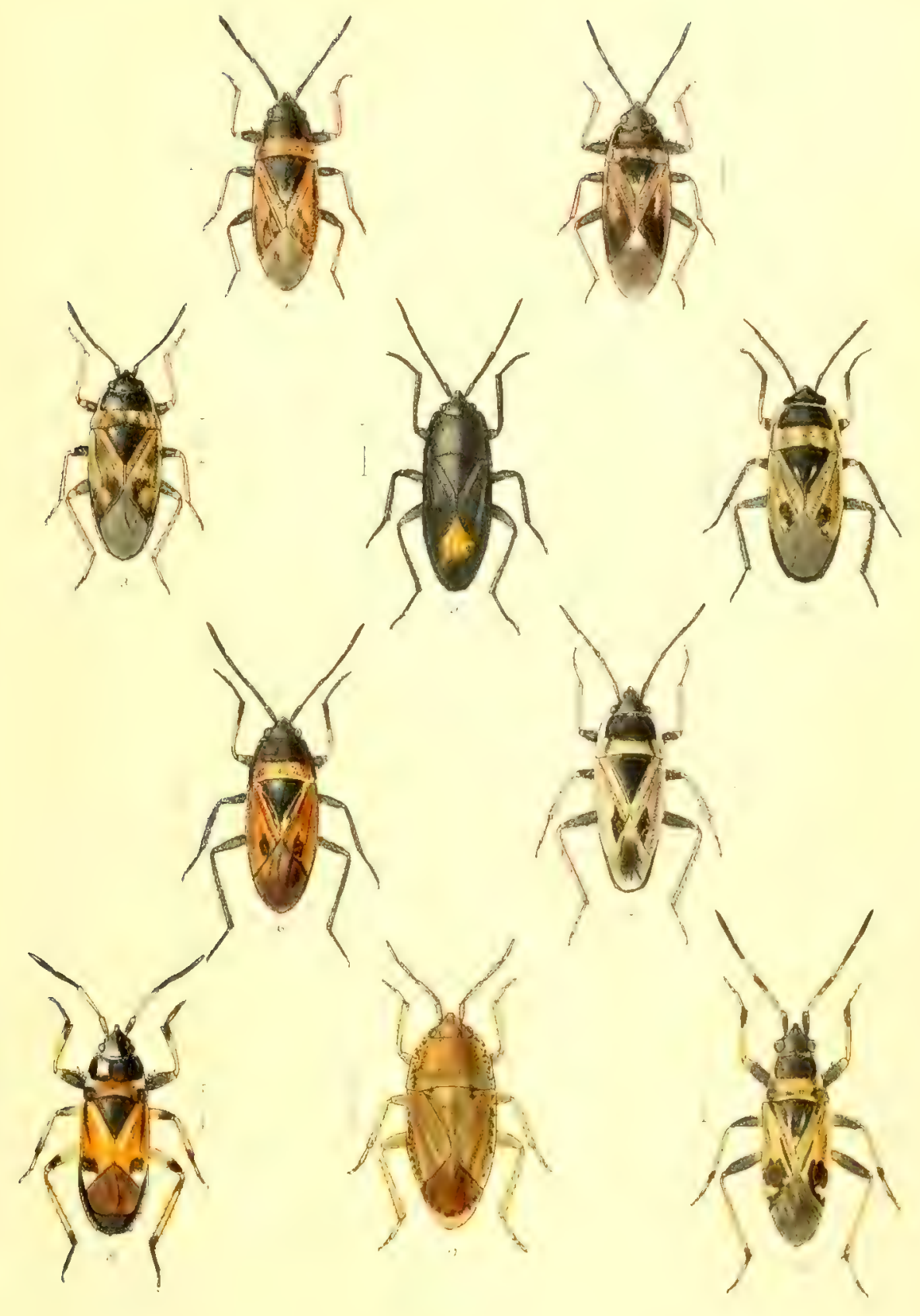






\section{PLA'I'E X.}

Fig, 1. Eremocoris fenestratus, $H$. Schf.

2. ", podagricus, $F a b$.

3. Scolopostethus pictus, Schill.

4. $"$ decoratur, Hahn。

5. Notochilus contractus, $I$. Sclif.

6. Drymis brunneus, Sahll.

7. " pilipes, Fie?.

8. " pilicornis, $M . \delta \cdot R$.

9. " picens, Hlor.

10. Gastroles ferruginous, $\operatorname{Lim}$. 

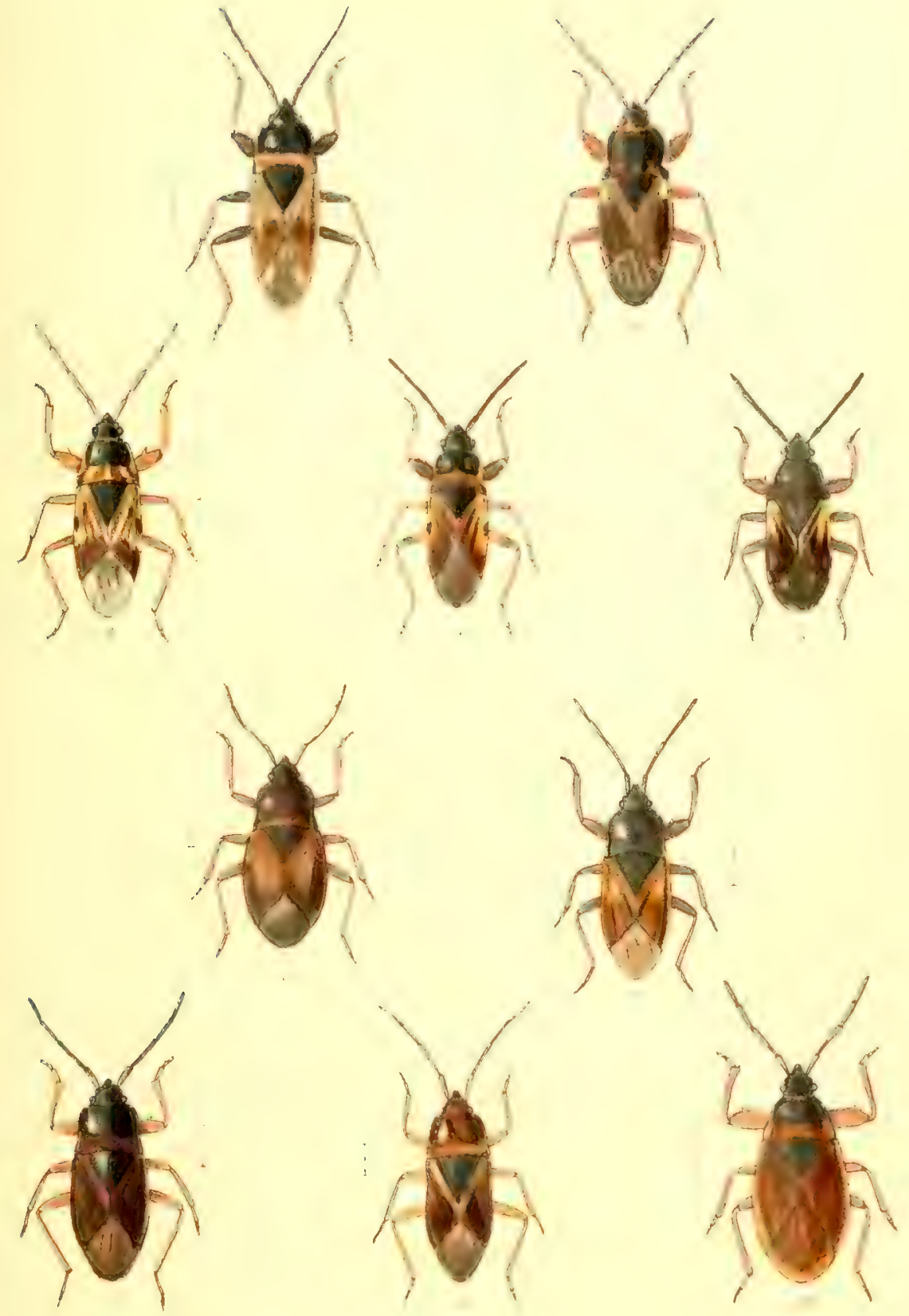



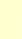




\section{PLATIE XT.}

FIc. 1. Gastrodes abietis, Limn.

2. Pyrrocoris apterus, Limn.

3. Pirsma quadrata, Fitb.

4. " capitata, Wolf.

5. Serenthia læta, Fall.

6. Campylostiri verma, Fall.

7. Orthostira brunuea, Germ.

8. " cervina, Germ.

9. ", nigrina, Fall.

10. " pirvula (developed), trall.

10. . , (undevelopei). 

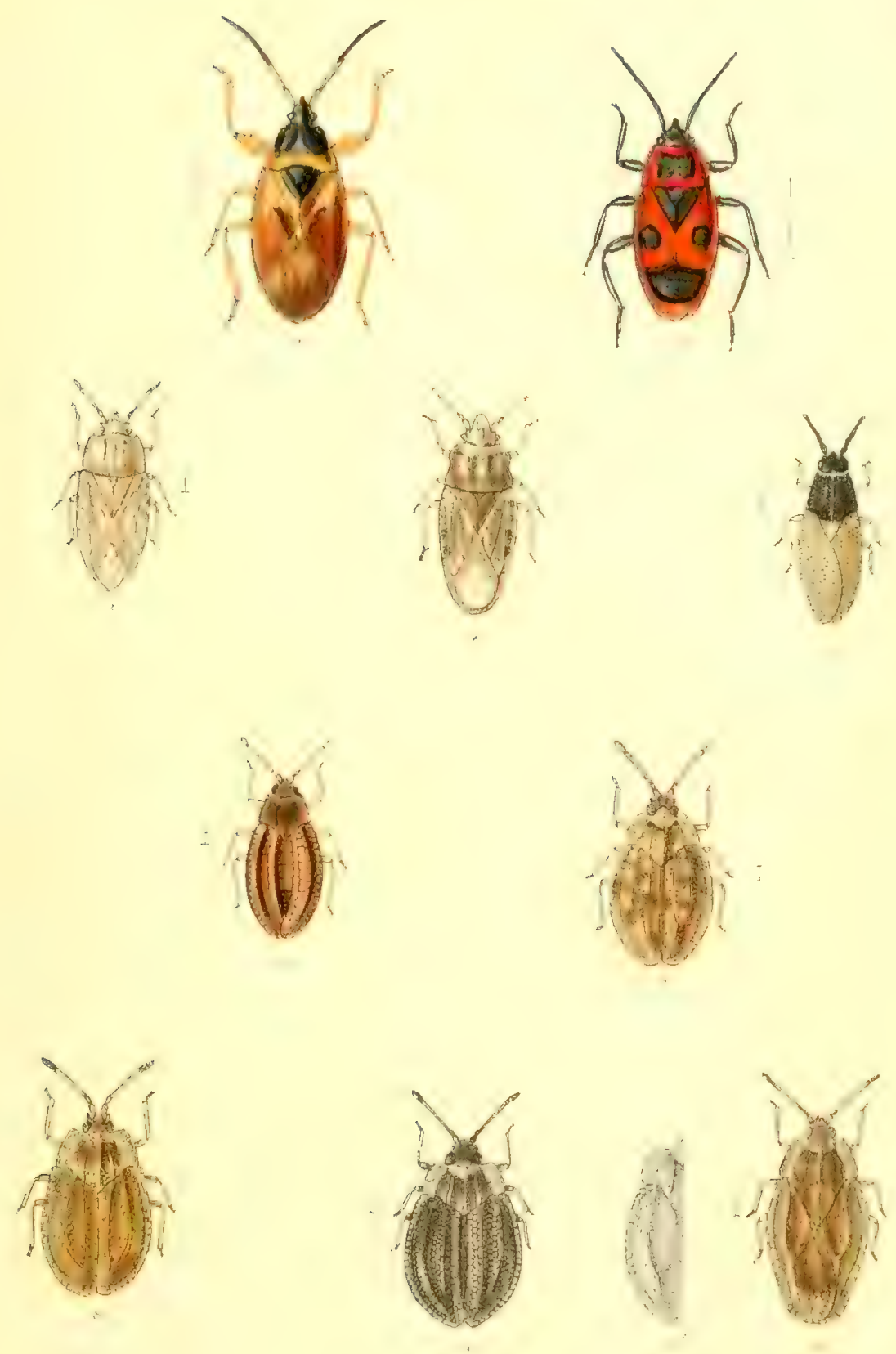




\section{PLA'IE XII.}

FrG. 1. Dictyonota crassi coruis, Full.

2. ", strichnocera, Fieb.

3. „, fuliginosa, Custa.

4. Derephysia folincen, Fall.

5. Monanthia ampliata, fiel.

ij. ", angustata, H. Schif.

7. , ciliata, Fice.

8. " costata, Fab.

9., 4 maculata, Wolf .

10. ", simplex, II. Schf. 

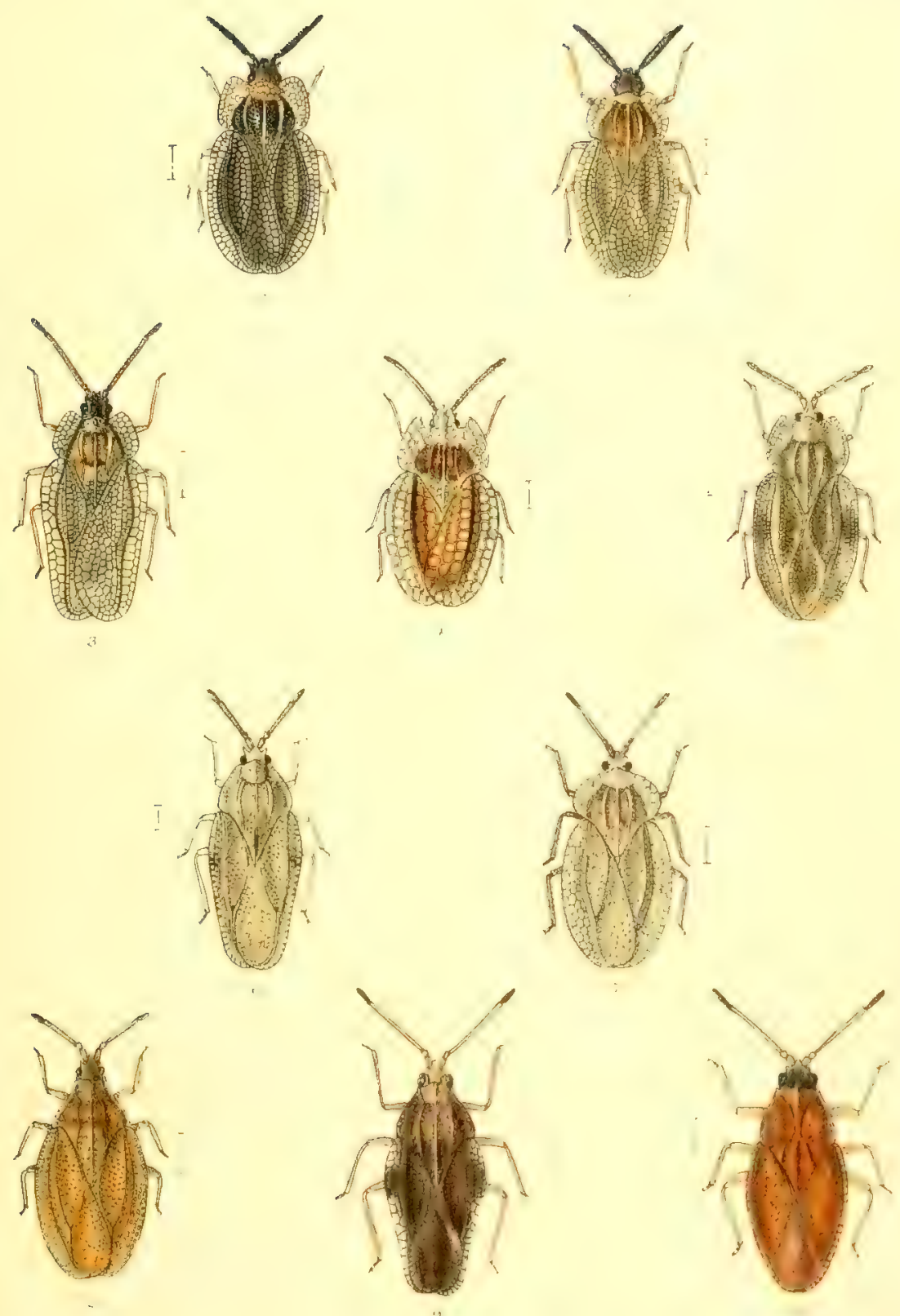


$$
\text { , }
$$





\section{PLATE XIII.}

FIsi, 1. Monanthia humuli, Fab.

$\therefore$ Aneurus lævis, Frab.

3. Aradus depressus, Fab.

1. , corticalis, Limn.

5. "Lawsoni, Saund.

6. Hebrus pusillus, Full.

7. Mesovelia furcata, $M \cdot \delta \cdot \boldsymbol{h}$.

8. Aëpophilus Bonnairei, Sign.

9. Hydrometra stagnorum, Linn.

10. Microvelia pygmma, Duf: 

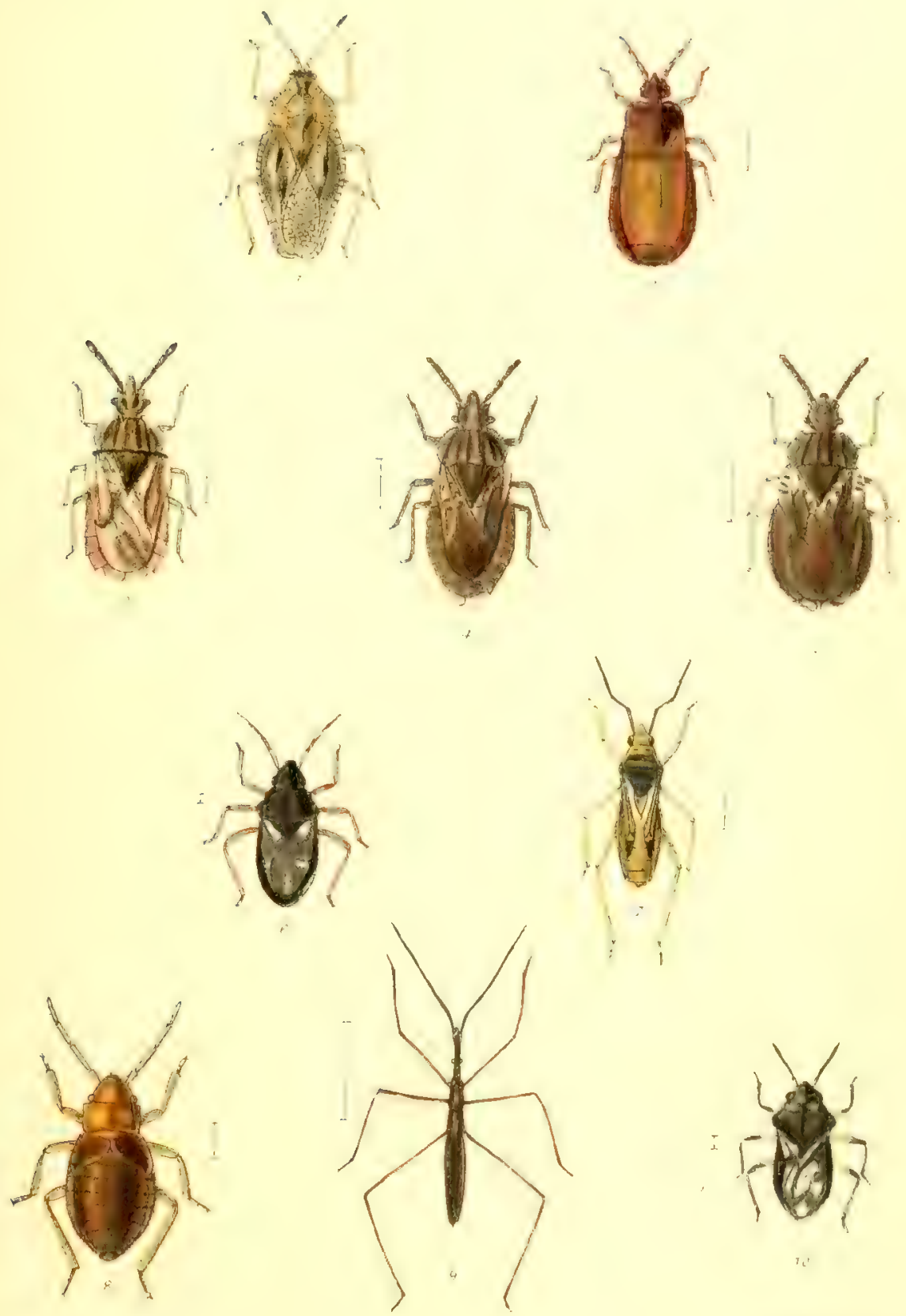


$$
\text { , }
$$





\section{PLATE XIV.}

Fir. 1. Velia currens, Fab.

2. Gerris rufoscutellata, Latr.

3. , paludum, Fab.

4. "Costx, H.S.

5. " aspera, Fieb.

6. „, gibbifera, Schum.

7. " lacustris, Linn.

S. " argentata, Schum.

9. Ploiaria vagabunda, Tin».

10. Pygolampis bidentata, Fuurc. 


$$
\begin{aligned}
& x+1 \\
& x+1 \\
& x+1
\end{aligned}
$$






\section{PLATE XV.}

FIg. 1. Reduvius personatus, Limn.

2. Coranus sub-apterus, De $G$.

3. Prostemma guttula, Fab.

1. Nabis brevipennis, Irahn.

$\therefore \quad$, lativentris (macropterous), Bo\%.

(i. ", major, Cost.

7. ", boops, Schiüate.

8. " tlavomarginatus (macropterous), Scholtz.

9. " limbatus, Dithll.

10. „, lineatus, Dahll. 

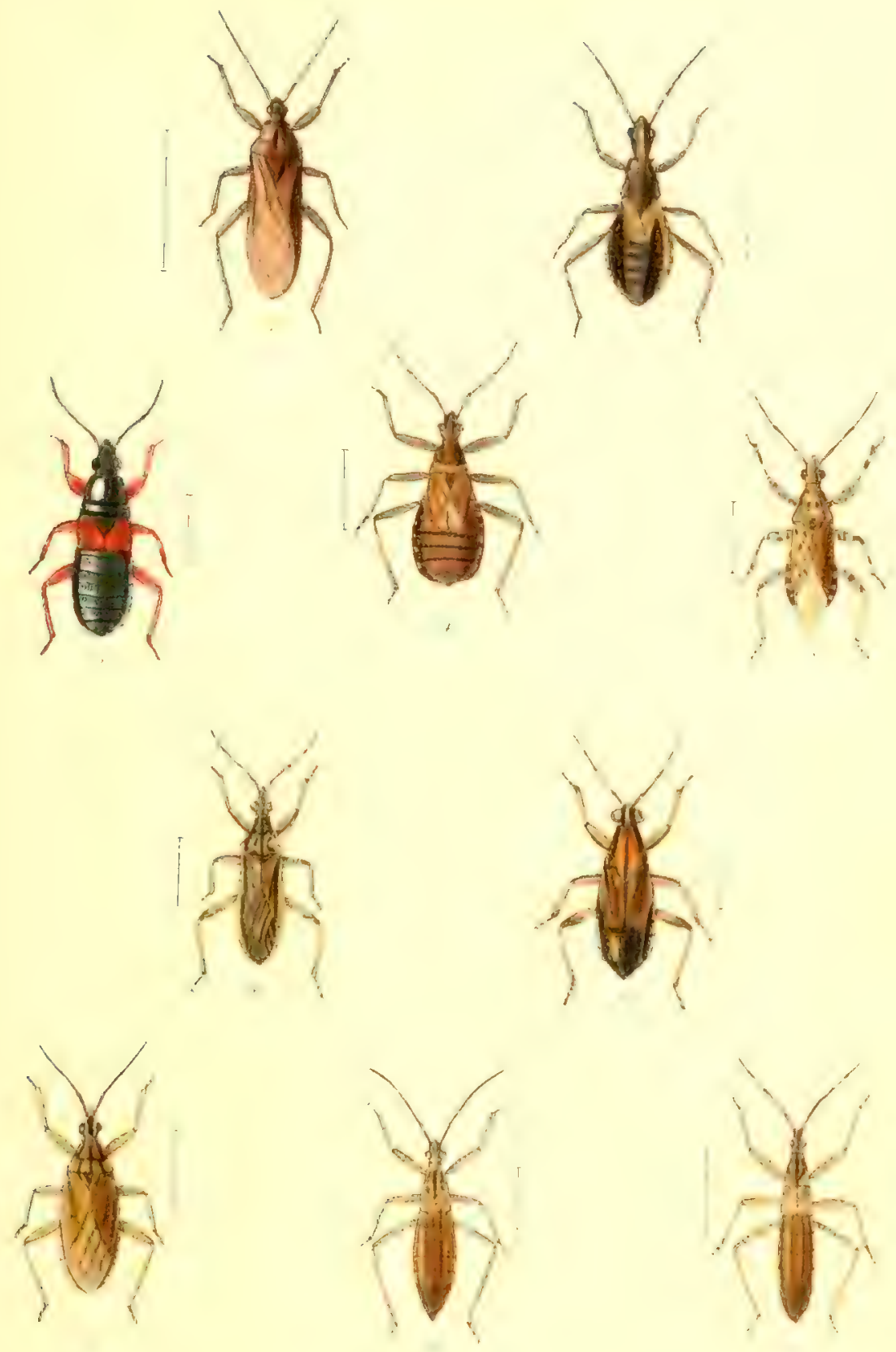




\section{PLATE XVI.}

Fig. 1. Nabis ferus, tim.

2. " rugrosus, Linn.

-3. Salda pilosa, Full.

-1 4. ", lateralis (macropternus), Fall.

fa. " " (brachypterous).

5. " riparia, Foll.

$\rightarrow 6$. , scotica, Curt.

7. ", morio, Zett.

-8. , littoralis, Linn.

9. " C. album, Firb.

10. " marginalis, Full. 

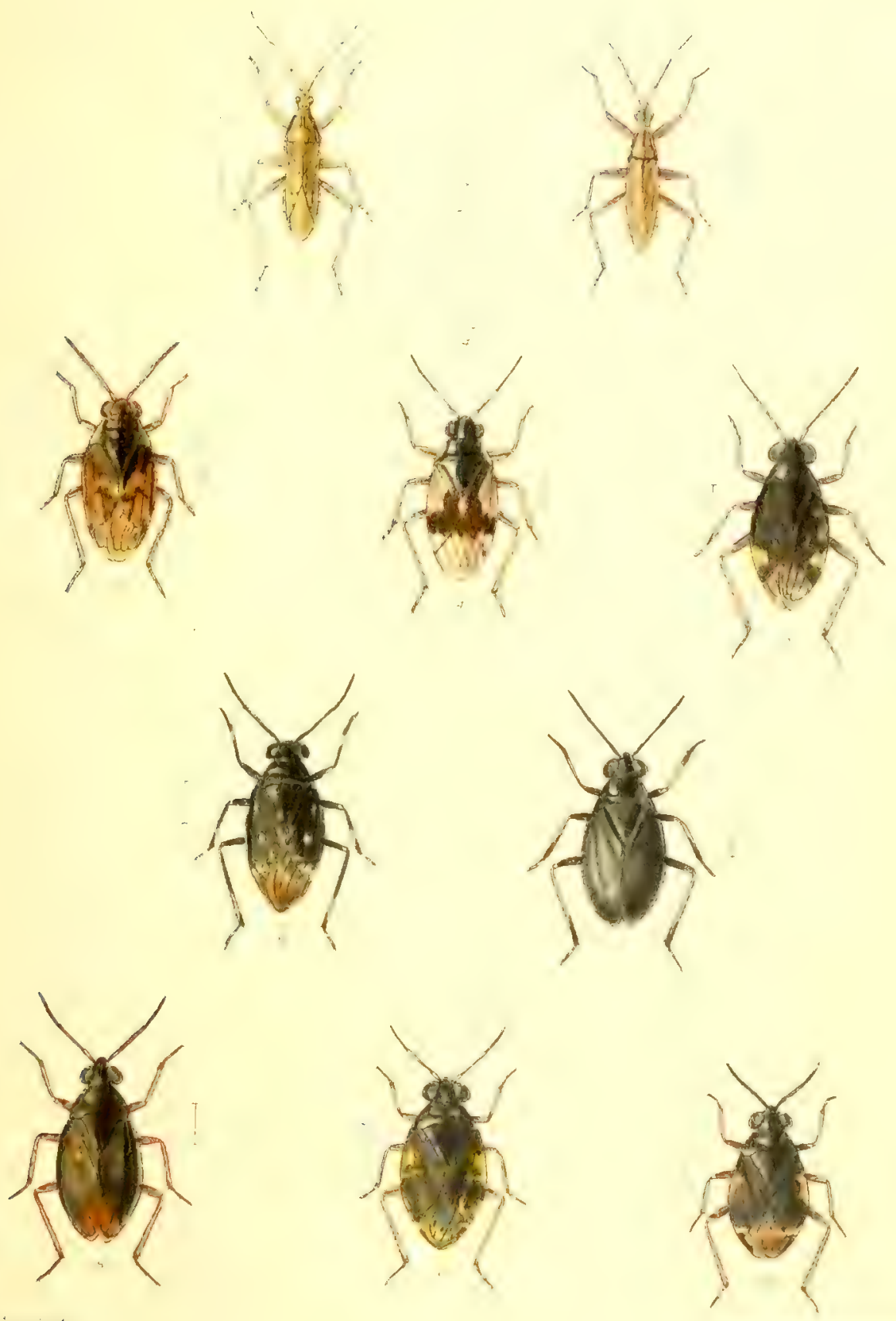



\section{PLATE XVII.}

IFig. 1. Salda clegantula, Full.

2. , cincta, $H_{0} . S^{\prime}$.

3. Ceratocombus coleoptratus, Zell.

4. Cryptostemma alienum, M.S.

5. Cimex lectularius, Lim.

6. "hirundinis, $J(n$.

7. , pipistrelli, Jen.

3. Lyctocoris campestris, Full.

9. Piezostethus galactinus, Fieb.

10. 2 formicetorum, Toh. 

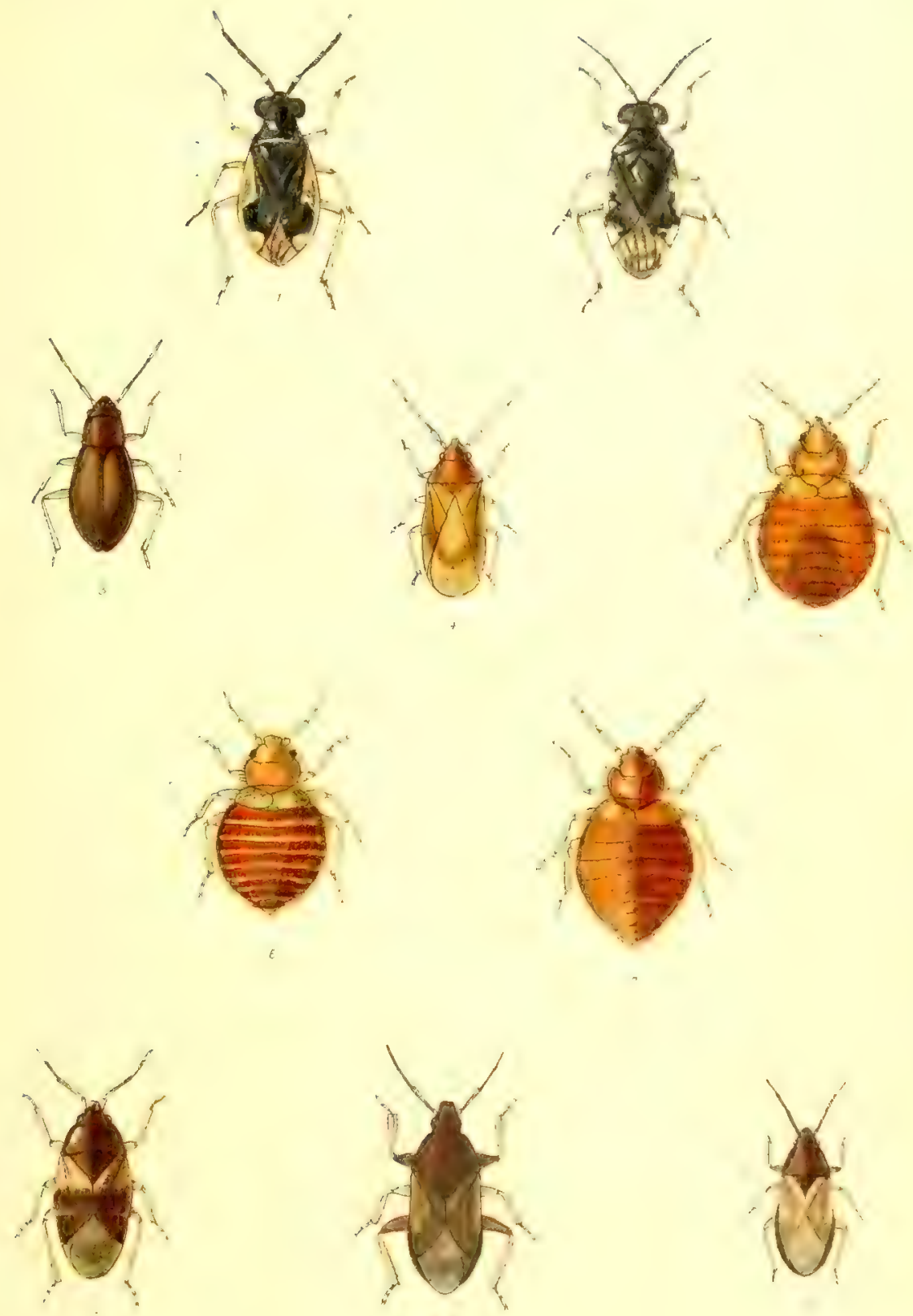




\section{PLATE XVIIT.}

l’. I. Temnostethus pusillus, H.S.

2. Elatophilus nigricoruis, Zett.

3. Anthocoris nemoralis, Fulb.

4. " Eallarum-ulmi, De Geer.

5. . . visci, Dougl.

6.,$\quad$ sylvestris, $\operatorname{Linh}$.

7. Tetraphleps vittata, Fieh.

8. Acompacoris alpinus, lieut.

9. Triphleps nigra, Wolti', ชే .

10. " majuscula, Reut. 

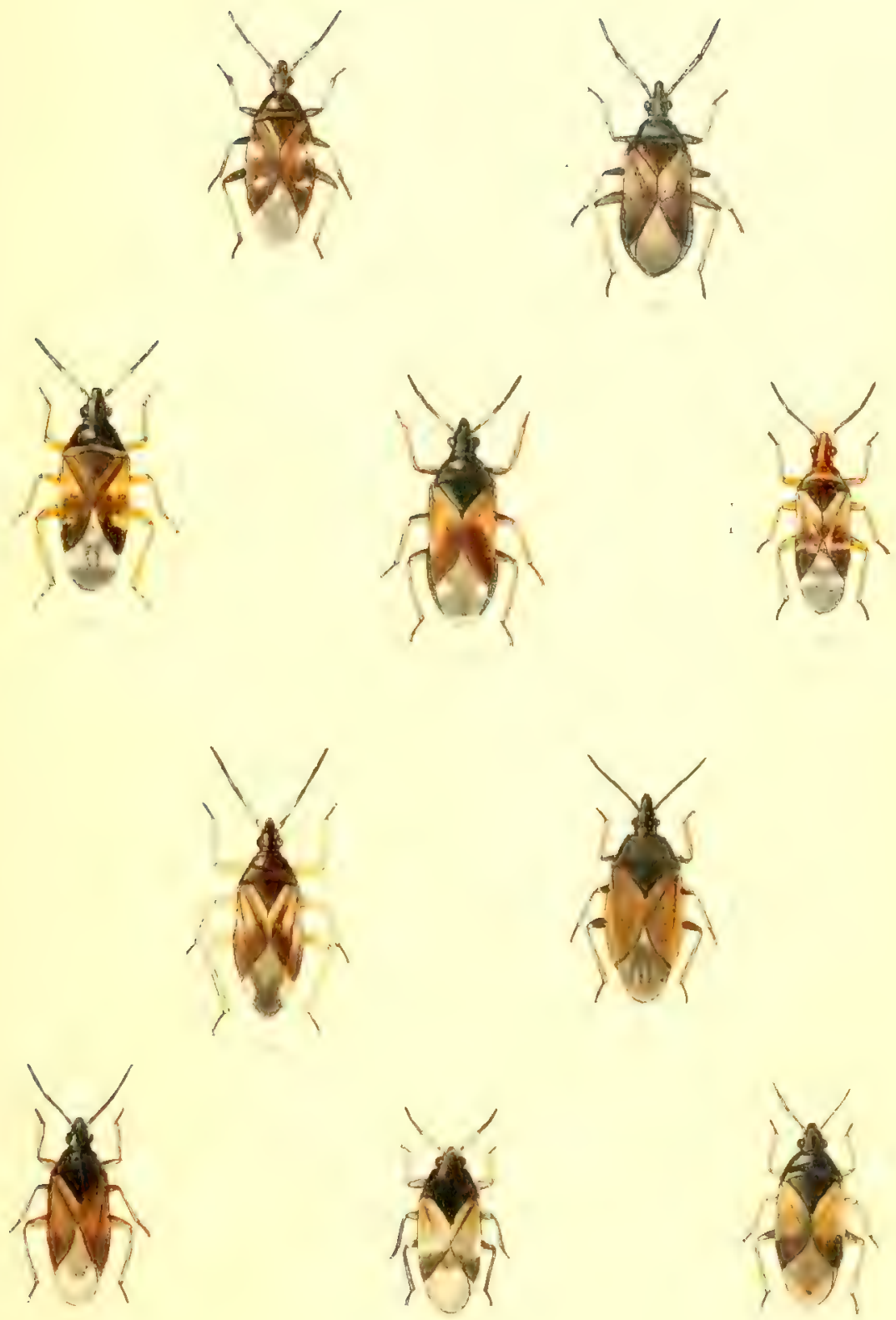




\section{PLA'E XIX.}

Fic. 1. Buchysteles parvicornis, Caxt.

2 . Cardiastethus fasciiventris, Garb.

3. Xylocoris ater, Duf:

4. Mycrophysa pselaphiformis, Curt, d.

i).

if. "elemantula, Baer, c.

7.

$\therefore$ Myrmedolia tenclla, Lett, d.

?. coleoptrata, Full., of

10. 

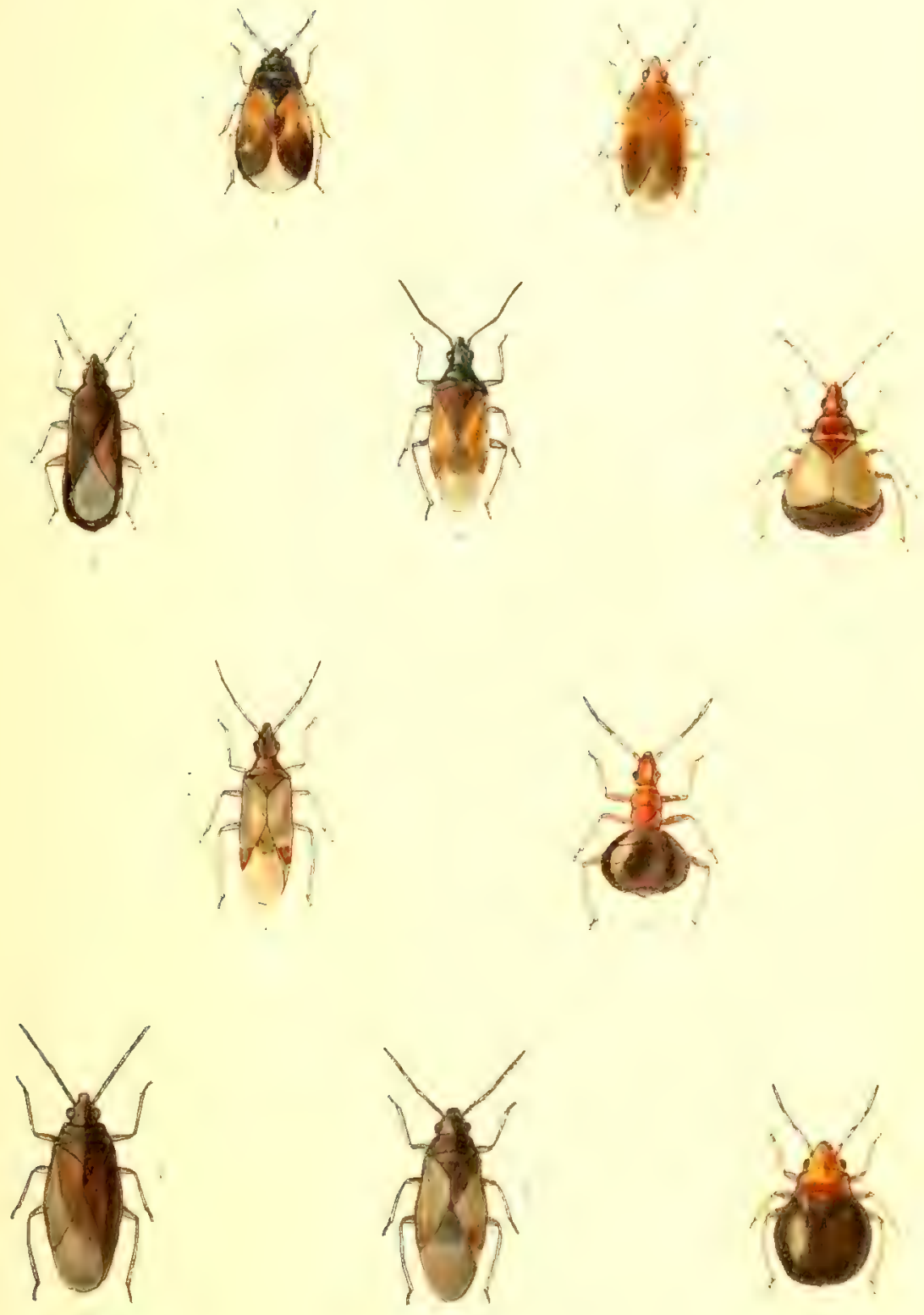

orban del, et 7 th 




\section{PLATE XY.}

il., 1. Pithanus Maerkeli, H.S.

$\therefore$ Acetropis Gimmerthali, Flor., ?.

'. Miris lævigatus, Linn.

1. ,, holsatus, Fub.

․ Mugnloceran erratica, Linn.

$\therefore$ ", longicornis, Fall.

i. Teritocoris anteunatus, Boh.

$\because \quad . \quad$ Saundersi, D. S. S

$\because$ Leptopterna ferrugata, Full.

11. " dolobrata, Lim. 


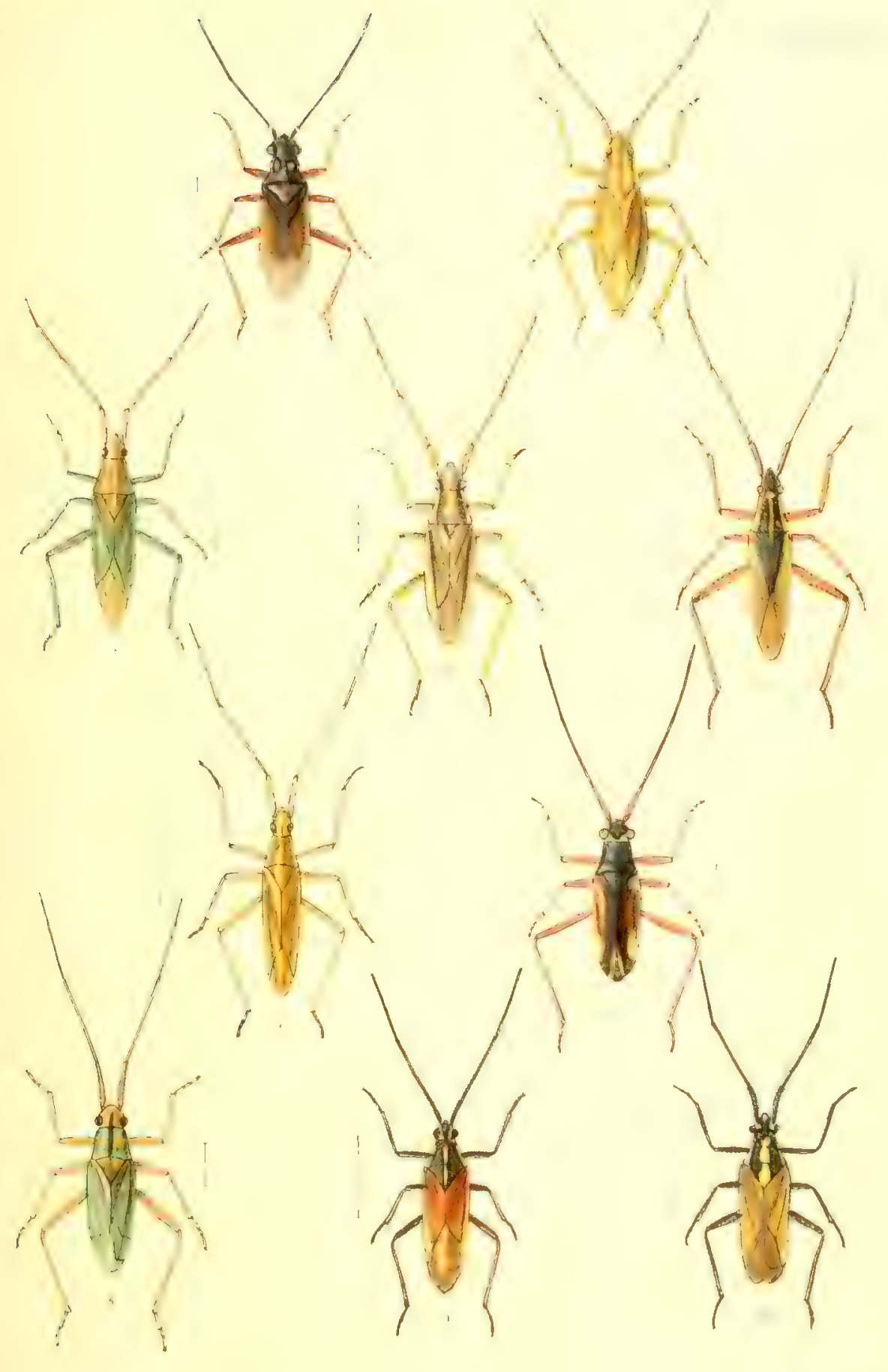

R. Morgan del, et lith 




\section{PLATE XXI.}

Fir. 1. Bryocoris pteridis, Full.

$\because$ Monalocoris filicis, Limn.

3. Pantilins tunicatus, $L a b$.

1. Lopus flavomarginatus, Don.

5. " sulcatus, Fieb.

6. Miriduis quadrivirgatus, Costa.

i. Phytocoris populi, Lim. var. distinctus, $U . \& \cdot \mathrm{s}$.

$\therefore$. tiliae, Iab.

1. " pini, $\mathbb{\pi} b m$.

11. , ulmi, Linn。 

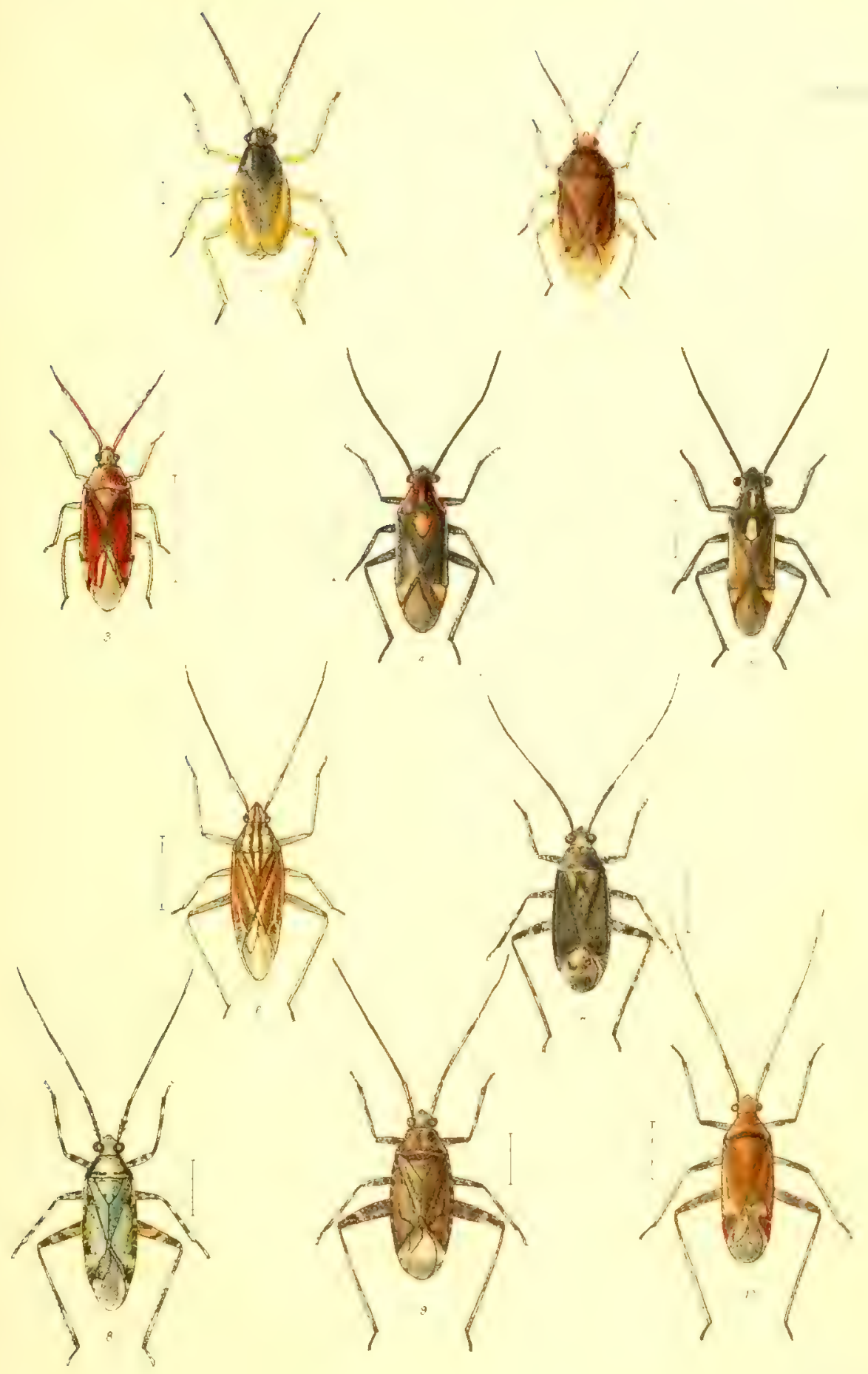

R.Moríger del et ithr. 




\section{PLATE XXIT.}

Fict. 1. Calocoris striatellus, Fub.

2. ., sexguttatus, Fab.

3. " ticinensis, Mey.

4. " seticornis, Fab.

5. " infusus, H. Scht.

6. " striatus, Lim.

7. Oncognathus linotatus, $F^{\prime}+h$.

S. Dichrooscytus rufipennis, Full.

9. Plesiocoris rugienllis, Futl.

10. Lygus pratensis, Fab. 


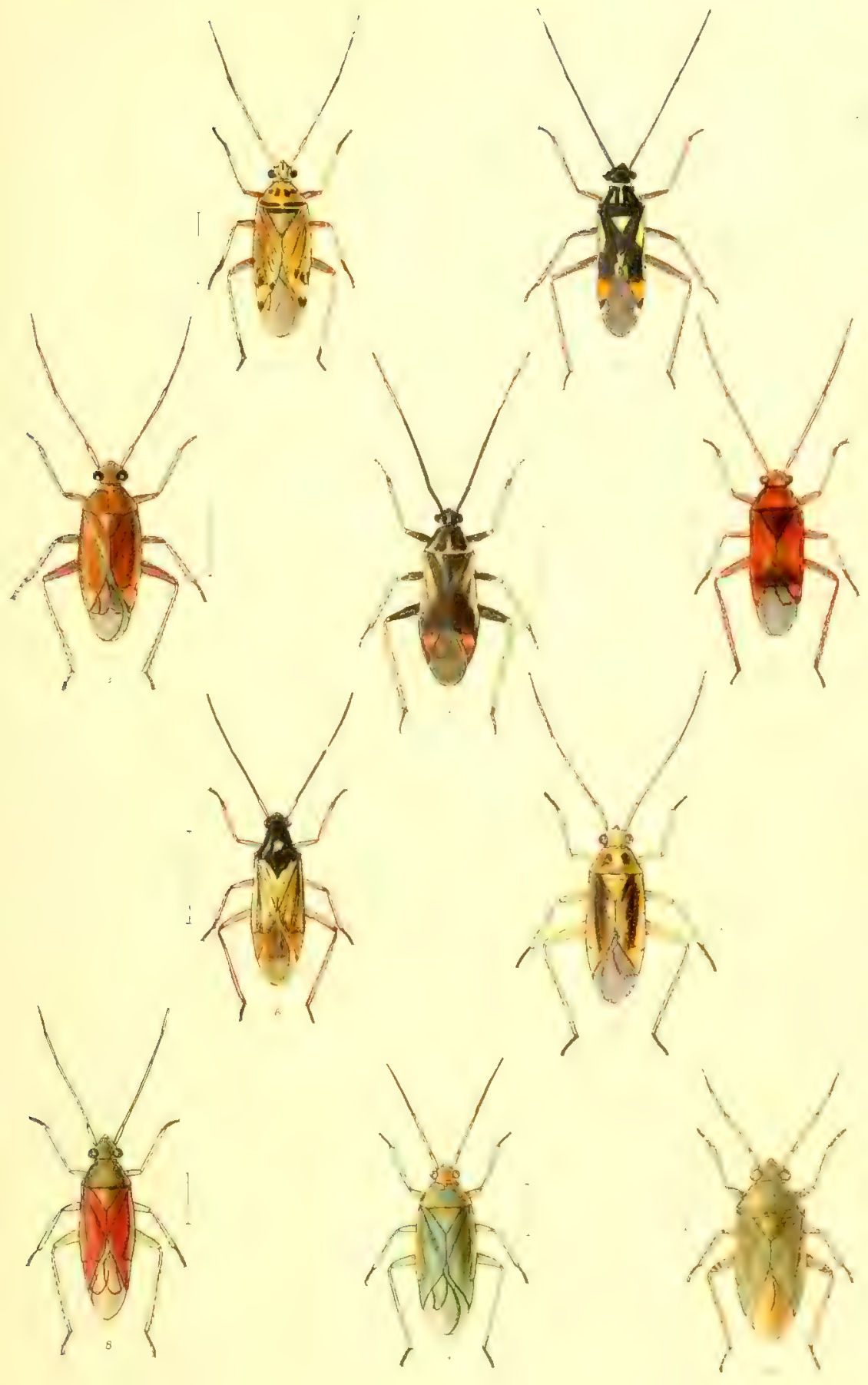

R. Norgan del, et Wh 




\section{PLATE XXIIT.}

Fig. 1. Lygus atomarius, Moy.

2. "viridis, Fall.

3. " limbatus, Fall.

4. ," Spinolæ, Mey.

5. . pabulinus, Lim.

6. . viscicola, Put.

7. , Kalnii, Linn.

8. Zygimus pinastri, full.

9. Peciloseytus nigritus, Fall.

10. " nnifasciatus, Fat. 

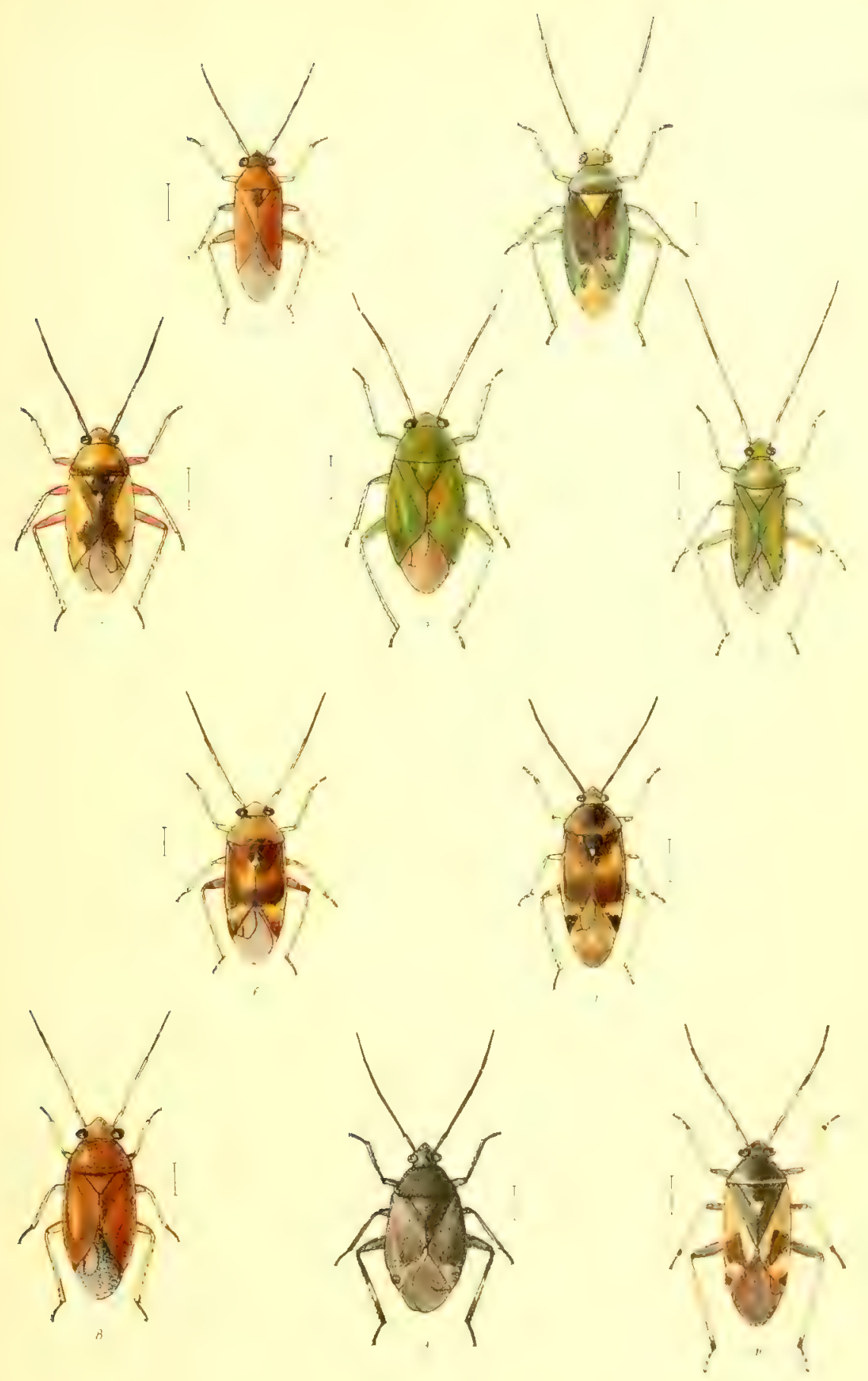

R. Morgan, del et lith 




\section{PLATE XXIV.}

FIG. 1. Camptubrochis lutescens, Schill.

2. Liveoris tripustulatus, $F_{a b}$

3. Capsus scutellaris, $F a b .$, q.

1. Bothynotus pilosus, Boh., $q$.

5. Rhopalotomus ater, Lirn.

6. Pilophorns elivatus, Linn.

7., cinnamopterus, $k$ ibm.

8. Systellonotus triguttatus, Limn.

9. Allodapus rufescens, Burm.

10. Halticus luteicollis, I'cnz. 

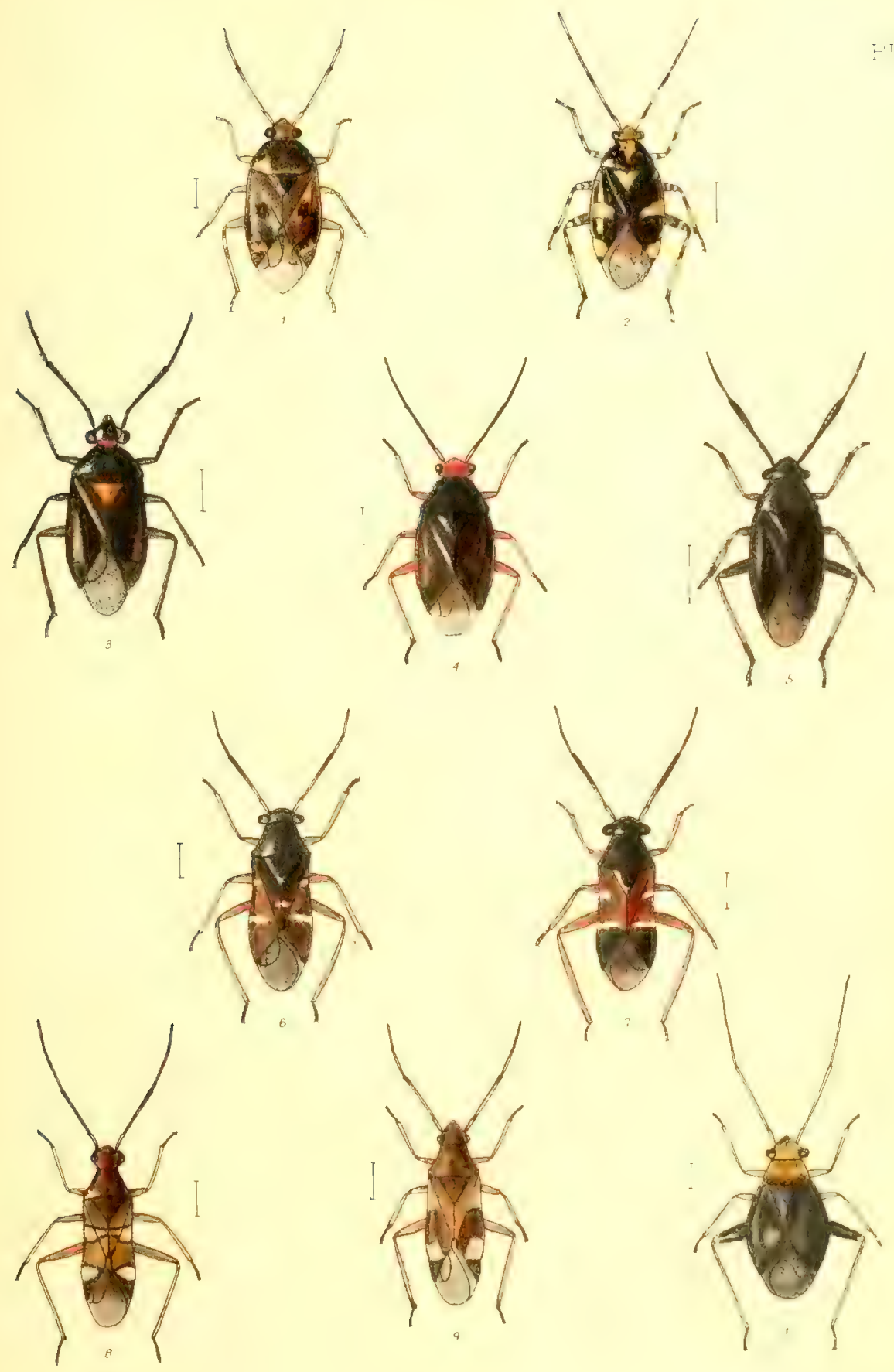




\section{PLATE XXV.}

Fir, 1. Strongylocoris luridus, Fall.

$\therefore$ Orthocephalus saltator, Hahm., \&, rle. veloped.

3. Macrolophus nubilus, H.S.

1. Dicyphus epilobii, Rent.

5. " pallidicornis, Fieb.

6. " annulatus, Wolff.

7. Campyloneura virgula, H.S.

Q. Cyllocoris histrionicus, Linno

!. "flavonotatus, Boh.

10. Etorhinus angulatus, $F$ rab. 


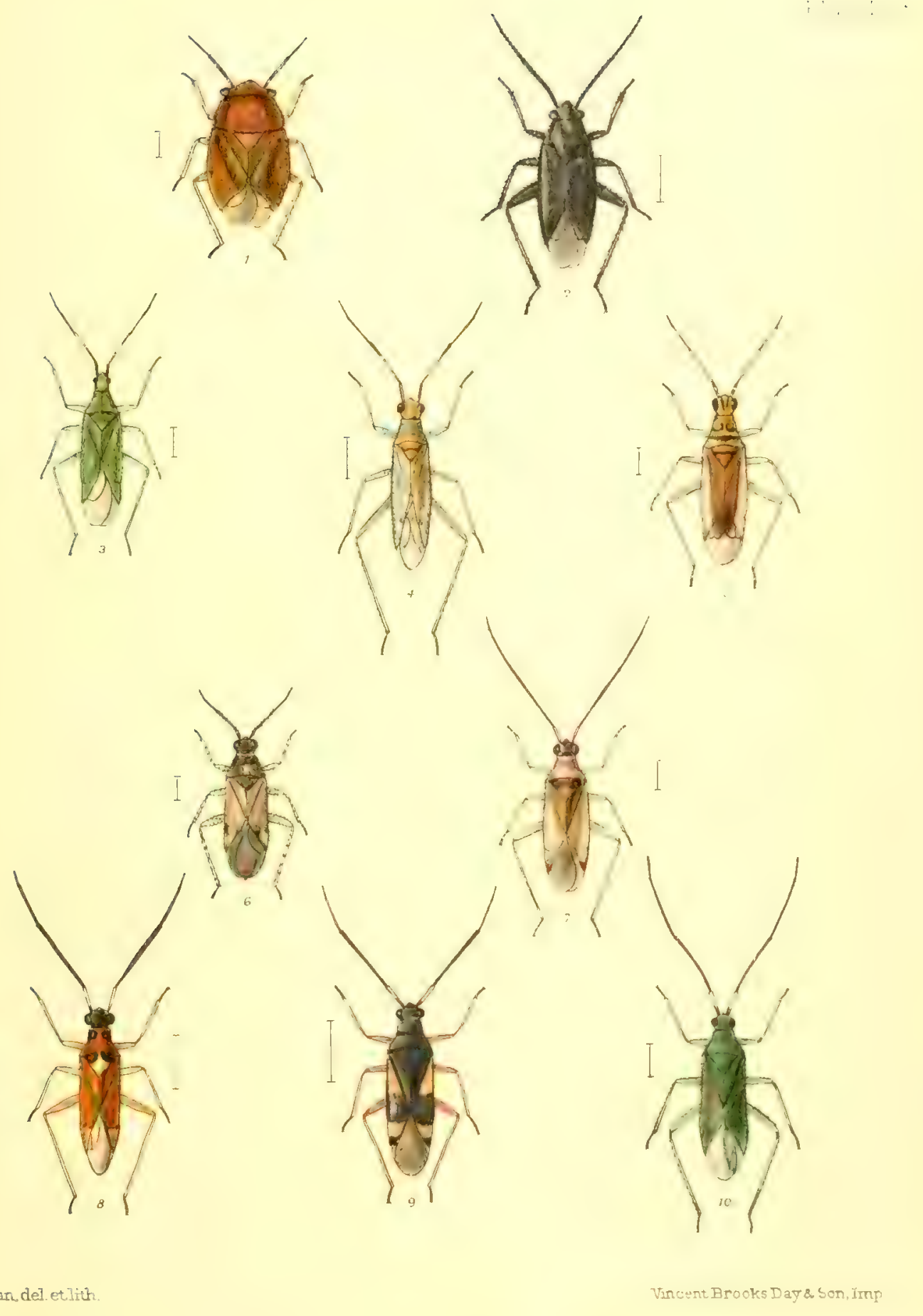





\section{PLATE XXVI.}

Fia. 1. Globiceps flavomaculatus, $F^{\top}(b$ b.

$\therefore \quad$ dispar, Bollo, ㅇ.

3. Mecomma ambulans, Full., $\delta$.

4.

5. Cyrtorrhinus caricis, Fuil.

6. " pygmæus, Lett.

7. Orthotylus bilineatus, Fall.

8. " flavinervis, $K l$.

9. " nassatus, $\mathrm{Fal}$.

10. $" \quad$ viridinervis, $k b$.

11. 16. ," prasinus, Full., right forceps.

11. b. " $"$ left,

12. a. " Scotti, Reut., ", ",

12. b. " " " right "

13. a. " ochrotrichus, D. \& S., ", ",

13. U. " " " left " 

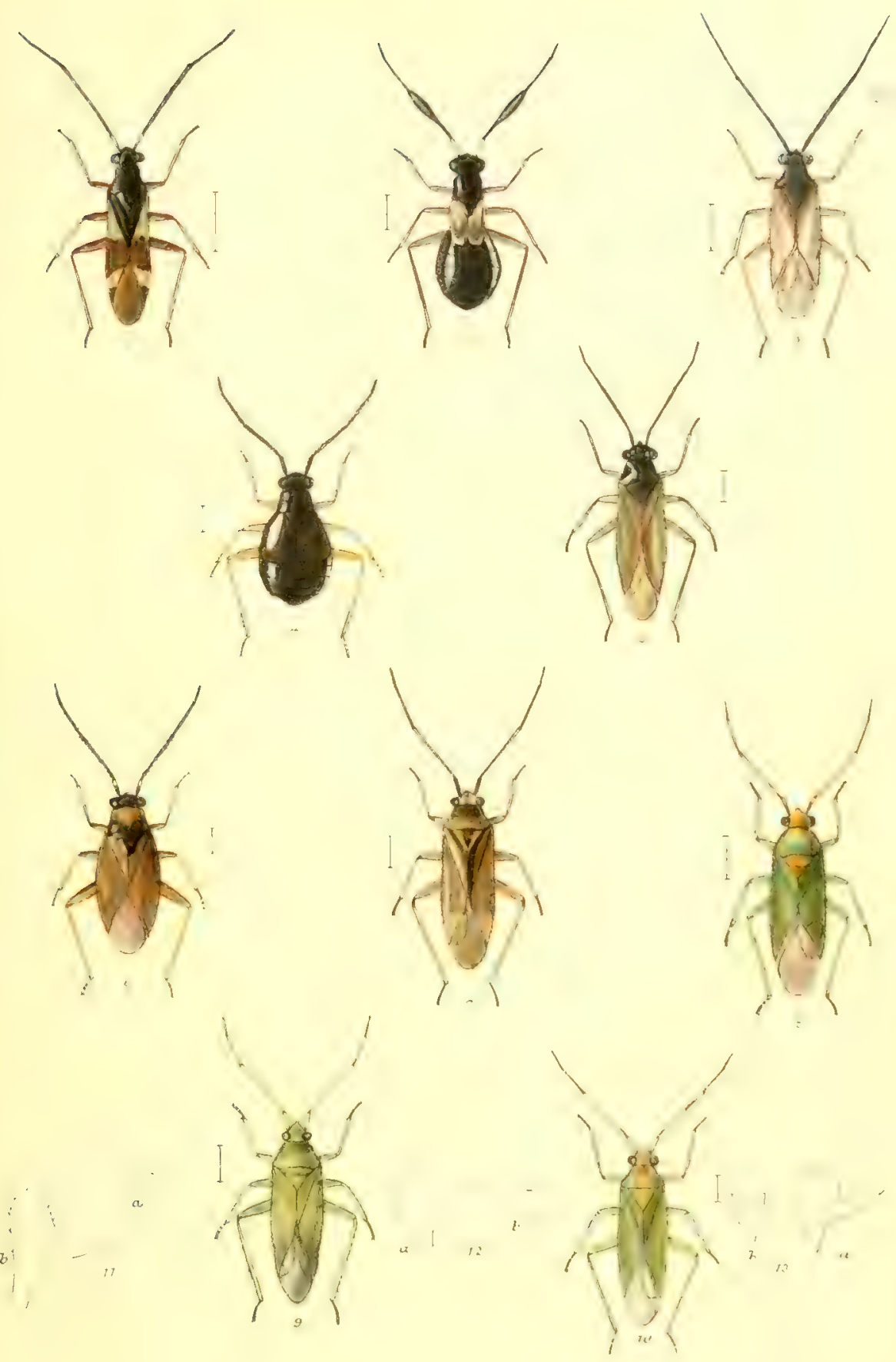




\section{PLATE XXVII.}

Fra. 1. Orthotylus Alavosparsus, Silulb.

$$
\begin{aligned}
& \therefore \quad \text { " adenocarpi, } P(r) \\
& \because \text {, }, \quad \text { rubidus, Fieb. S. Put. } \\
& \text { 1. }, \text { ericetorum, Full. } \\
& \text { 5. Hypsitylus bicolor, D. \& ڤ. } \\
& \text { 6. Loxops coccinea, Mey. } \\
& \text { 7. Heterotoma merioptera, scop. } \\
& \text { S. Heterocordylus genistæ, Scop. } \\
& \text { 9. Nalococoris chlorizans, Full. } \\
& \text { 10. Onychumenus decolor, Fill. }
\end{aligned}
$$



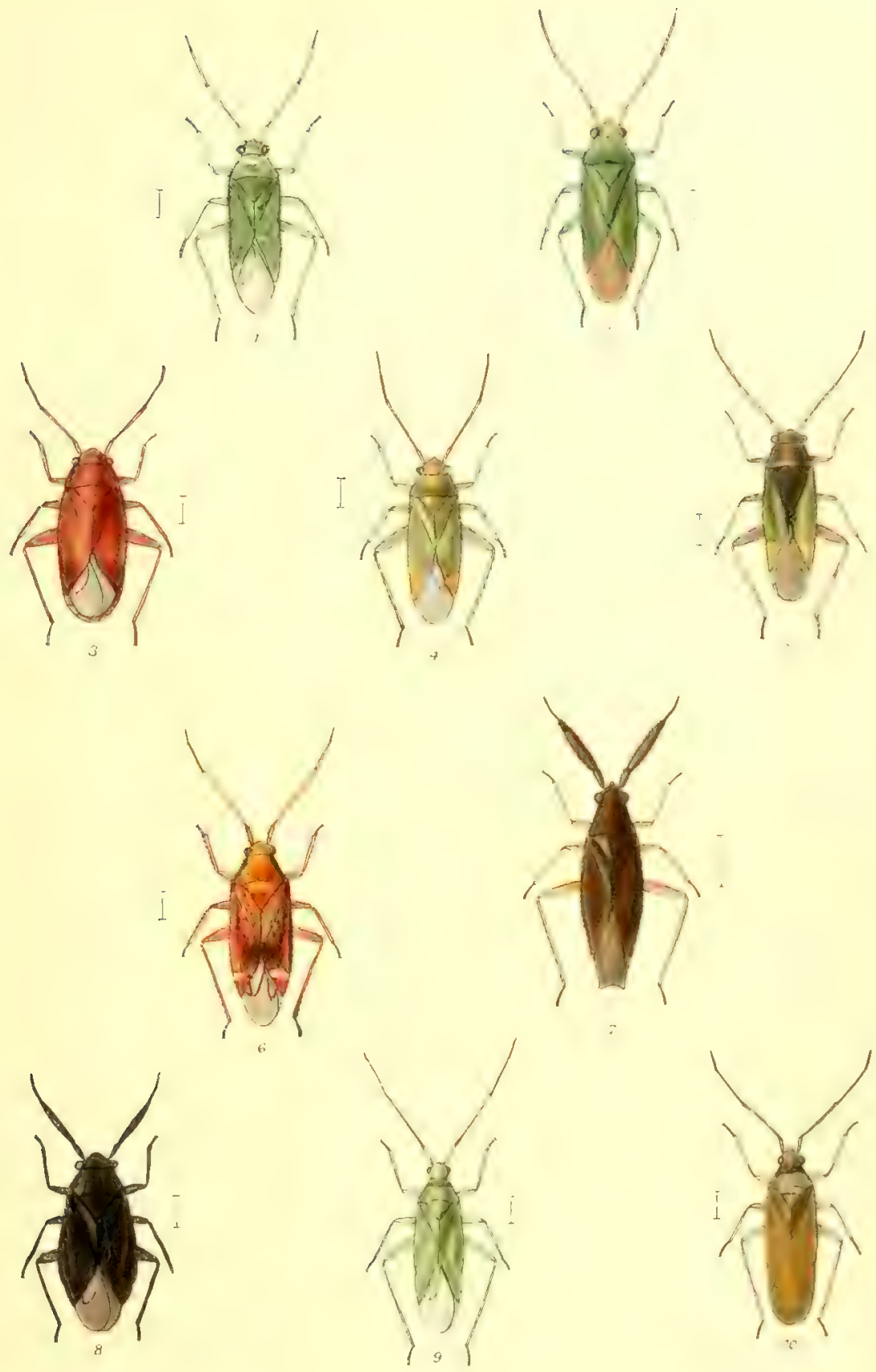

RMorsan, del etirth. 

2 


\section{PLATE XXVIII.}

List. 1. Oncotylus viridiflavus, Goeze.

2. Macrotylus solitarius, Mey.

$\therefore$ Conostethus salinus, Sathll.

1. Hoplomachus Thunbergi, Full.

万. Macrocoleus hortulanus, Mey.

ii. " tanaceti, Full.

7. Amblytylus delicatus, Perr.

-. " brevicollis, Fieh.

9. Harpocera thoracica, Fall.

10. Byrsoptera rufifrons, Fall. 

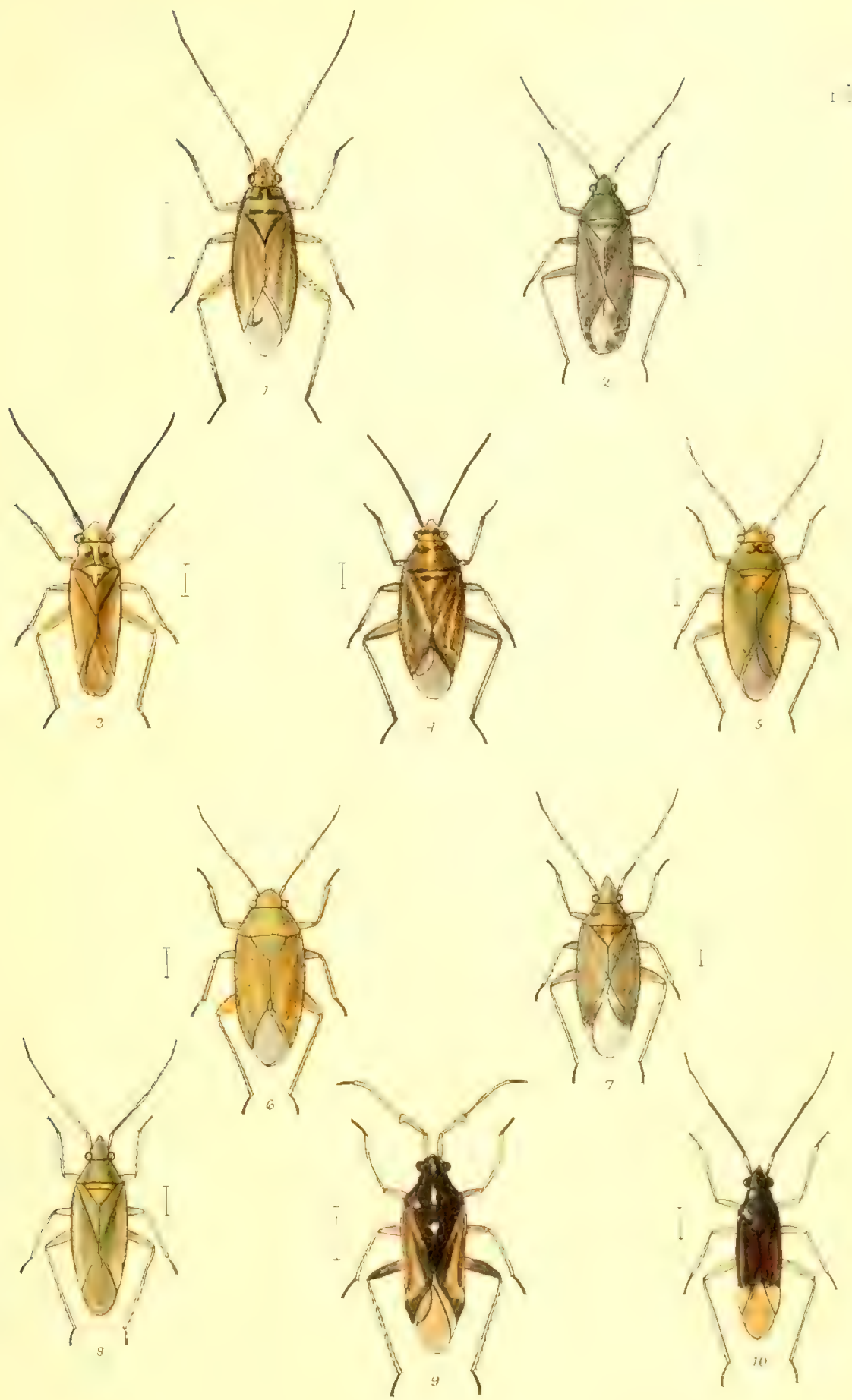

R Mor ban, del et jith

Vincen Erooks' dy \&o Son, tmp 


\section{.}





\section{PLATH XXIX.}

Fis. 1. Phylus palliceps, Fieb.

2. s. coryli, Linn.

3. Plesiodema pinetellum, Zett., $q$.

4. Atractotomus mali, Mey., \&.

5. Psallus betuleti, Full., $\uparrow$.

6. , variabilis, Fall., + .

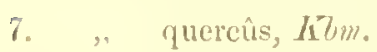

8. , alnicola, 1$)$. \& $S$.

9. " varians, $I$. Schf.

10. , sanguineus, $F a b$. 

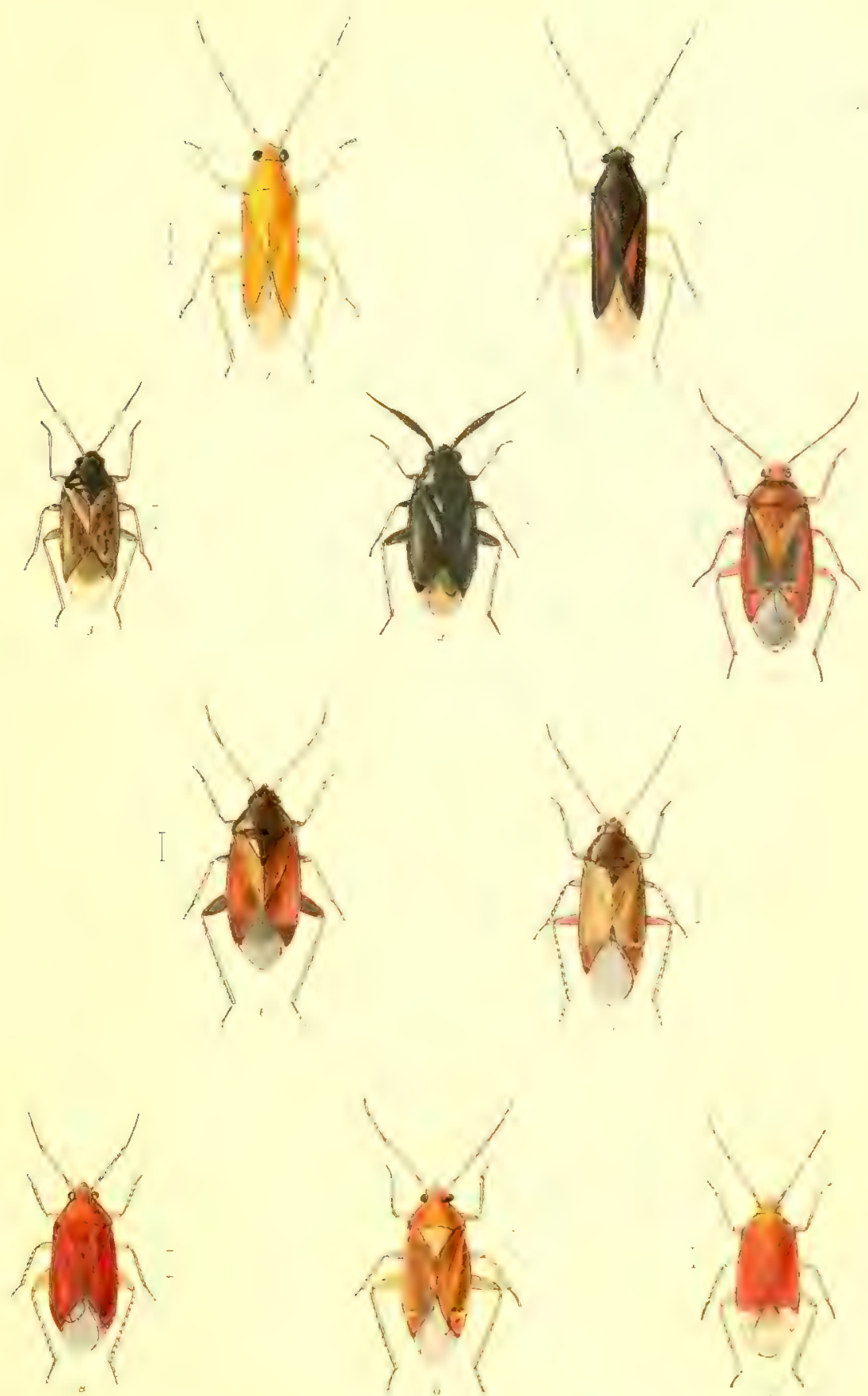




\section{PLA'IE XXX.}

Fri. 1. Psallus Rotermundi, Sehltä.

2. Plagriognathus albipennis, Fall.

$\therefore$, arbustorum, $F a b$.

4. Roseri, H. Schf.

i. " Bohemanni, Full.

6. $"$ saltitans, Full.

7. Asciodema Fieberi, D. \& $S$.

$\therefore$ Naucoris cimicoides, Limn,

9. Aphelochirus astivalis, $F^{\prime} u b$.

10. Nepa cinerea, Limn. 

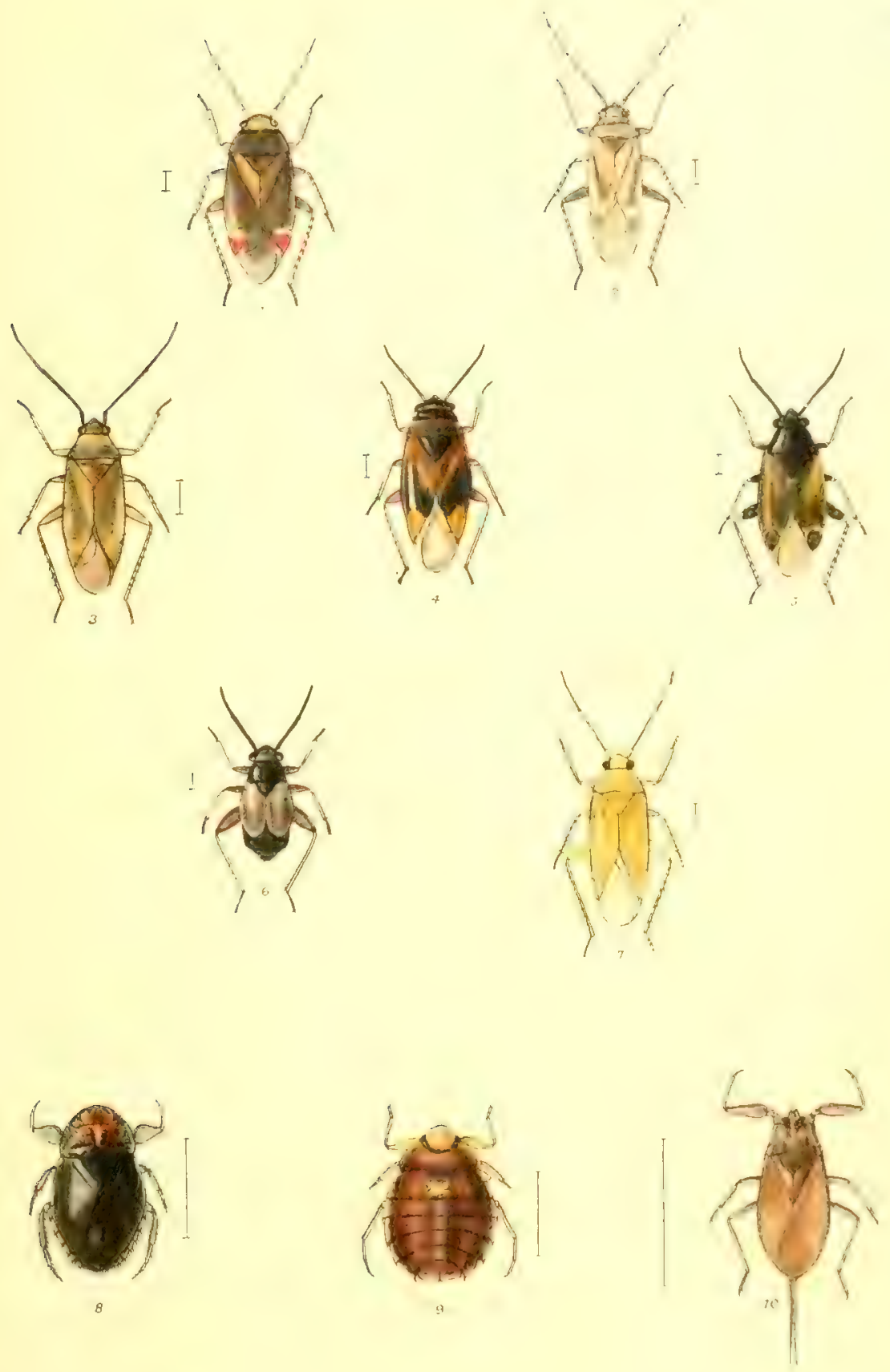




\section{PLATE XXXI.}

Fig. 1. Ranatra linearis, Limn.

2. Notonecta glauea, Linn.

3. Plea minutissima, Fab.

4. Corixa Geoffroyi, Leach

5. , concinna, Fieb.

6. , striata, Linn.

7. " Fallenii, Fieb.

8. ", eavifrons, Thoms.

9. " coleoptrata, $F a b$.

10. Sigara Scholtzii, Fieb. 

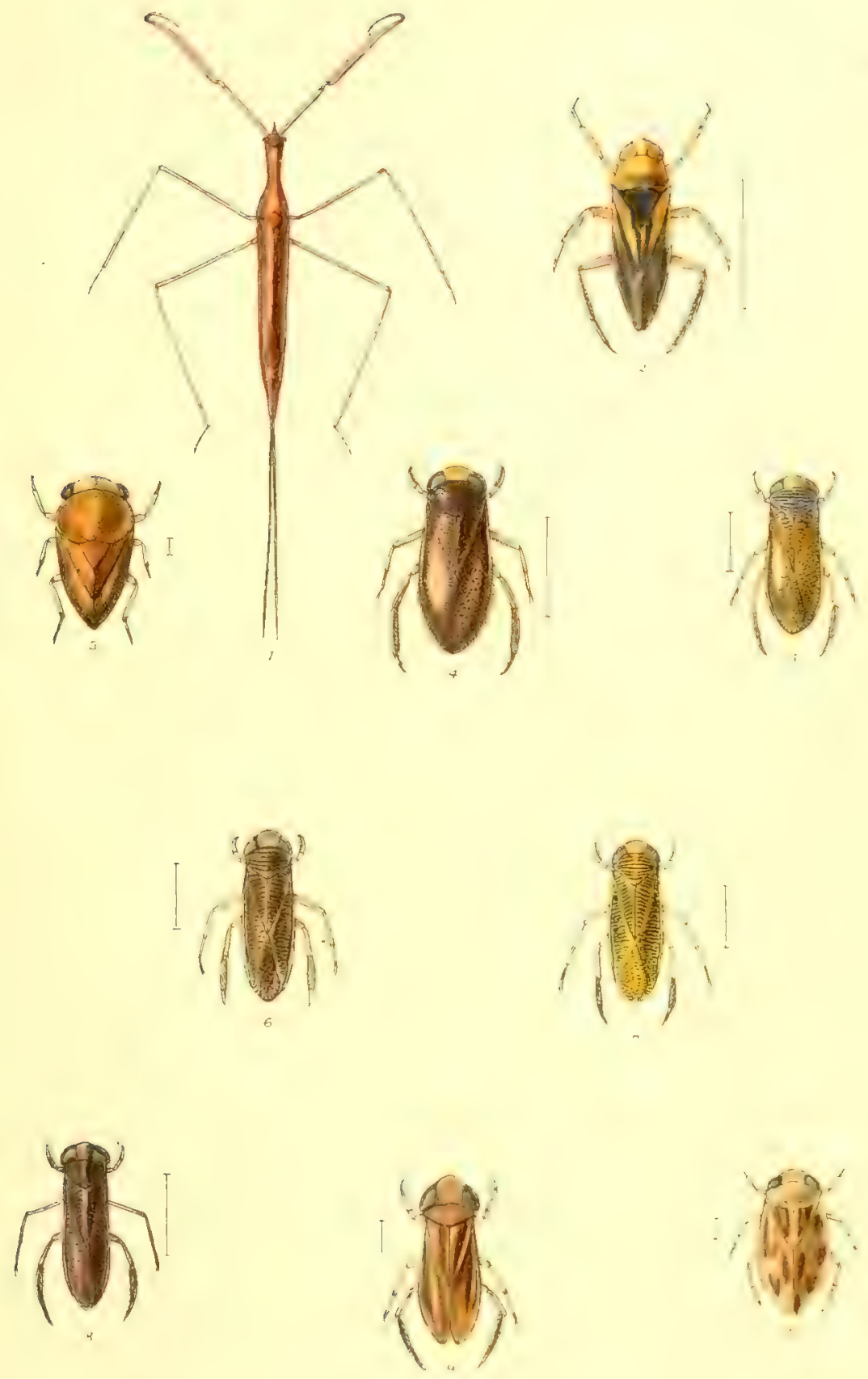

R Morgaridel et lith 




\section{PI,ATE XXXII.}

Fisi. 1. Pronotum of Corixa distincta.

$\because$., walleni.

$\therefore$ liace of Corixa semistriata, तs.

1. . . limitata, $\sigma^{\circ}$.

5. . Pritricii,

(i. ., , venusta, d.

i., , fossarum, of.

4. Elytron of Orthostime (Tingididx) (diagram). A. Sutural arca; B. Discoidal ditto; C. Lateral ditto; 1). Marginal ditto.

3. Elytron of one of the Capsida (diagram). A. Clavus; B. Corium; C. Cuneus; D. Membrane; E, E. Cells of membrane.

11. Elytron of one of the Cimicide (diagram). A. Clavus; 13. Corium; C. Lnbolium; D. Cuneus; F. Membrane.

11. Wing of a Capsid, showiug hamus of cell at A.

I:. Upper side of one of the Pentatomida (diagram). $\Lambda$. Head; $\mathbf{A}^{1}$. Central lobe of face; $\Lambda^{2}$. Antenna ; $\Lambda^{*}$. Eyes (compound); $\Lambda^{!}$. Ocelli. B. Pronotum; B $^{2}$. Anterior angles; $\mathrm{B}^{2}$. Posterior ditto. C. Sentellum. D'. Corium of Elytra ; $D^{2}$. Clavus of ditto ; $\mathrm{D}^{3}$. Membrane of ditto. Ii. Abdomen; $\mathrm{E}^{3}-\mathrm{E}^{5}$ Segments of Connexivum. $\mathrm{F}^{\mathrm{1}}, \mathrm{F}^{\mathrm{m}}, \mathrm{F}^{\mathrm{T}}$. Femora, Tibire, and 'Tarsi of legs.

1:) Underside of one of the Pentatomidn (diagram). A. Head; $A^{1}$. Rostrum; $A^{2}$. Antennx; $A^{3}$. Eyes. B. Prosternum; $\mathrm{B}^{1}$. Acetabulum; $\mathrm{B}^{2}$. Coxæ; B $^{3}$. Trochanter; $B^{6}$. Femur; B. $^{5}$ Tibia; $B^{6}$. 'Tarsi. C. Mesosternum, legs, \&e., as prosternum. 1). Metasternum, ", ", $\mathrm{D}^{i}$. Orifice of odoriferous sac. $\mathrm{E}^{\prime}, \mathrm{E}^{2}$, \&c. Abdominal segments, the black dots being the stigmata. $\mathbf{E}^{2}$. Showing basal process, as in Piezodorus. $\mathrm{E}^{7}, \mathrm{E}^{8}$. First and second grenital segments. 

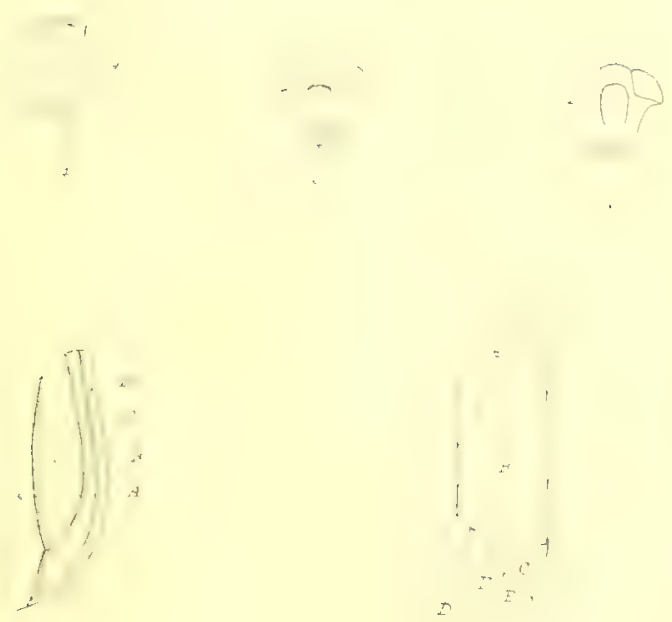

$s$
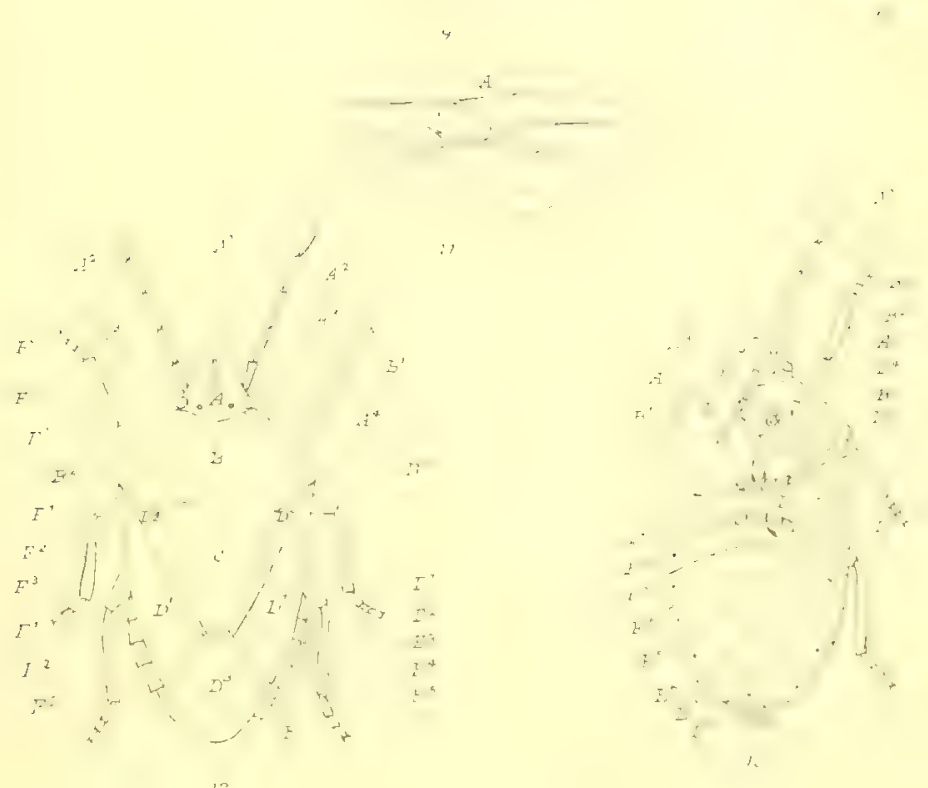

I 


